\title{
Climate change and primary industries
}

Impacts, adaptation and mitigaton in the Nordic countries 

4 norden 



\section{Climate change and primary industries}

Impacts, adaptation and mitigation in the Nordic countries 
Climate change and primary industries

Impacts, adaptation and mitigation in the Nordic countries

ISBN 978-92-893-2833-3

ISBN 978-92-893-2834-0 (EPUB)

http://dx.doi.org/10.6027/TN2014-552

TemaNord 2014:552

ISSN 0908-6692

(C) Nordic Council of Ministers 2014

Layout: Hanne Lebech

Cover photo: Jørgen E. Olesen

Print: Rosendahls-Schultz Grafisk

Copies: 166

Printed in Denmark

This publication has been published with financial support by the Nordic Council of Ministers. However, the contents of this publication do not necessarily reflect the views, policies or recommendations of the Nordic Council of Ministers.

\section{www.norden.org/en/publications}

\section{Nordic co-operation}

Nordic co-operation is one of the world's most extensive forms of regional collaboration, involving Denmark, Finland, Iceland, Norway, Sweden, and the Faroe Islands, Greenland, and Åland.

Nordic co-operation has firm traditions in politics, the economy, and culture. It plays an important role in European and international collaboration, and aims at creating a strong Nordic community in a strong Europe.

Nordic co-operation seeks to safeguard Nordic and regional interests and principles in the global community. Common Nordic values help the region solidify its position as one of the world's most innovative and competitive.

\section{Nordic Council of Ministers}

Ved Stranden 18

DK-1061 Copenhagen K

Phone (+45) 33960200

www.norden.org 


\section{Content}

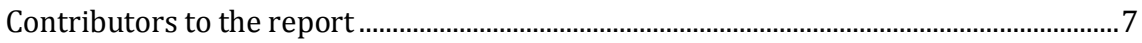

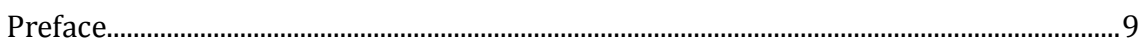

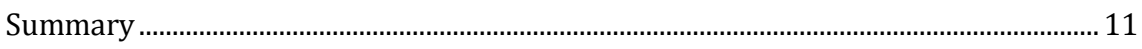

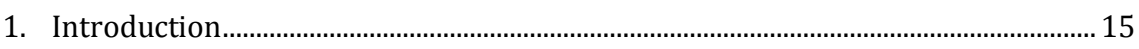

1.1 Background for the programme..................................................................... 15

1.2 Research funding ........................................................................................... 16

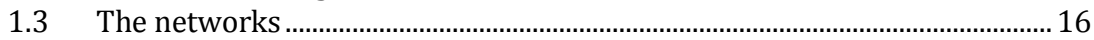

2. Climate and climate change in the Nordic countries ............................................... 21

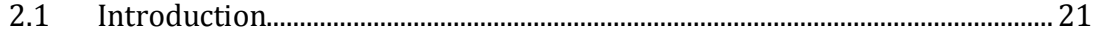

2.2 The climate of the Nordic region...................................................................... 22

2.3 Impacts of climate change in the Nordic region.............................................. 23

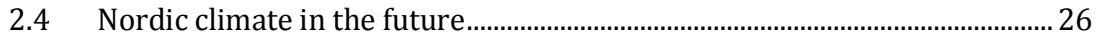

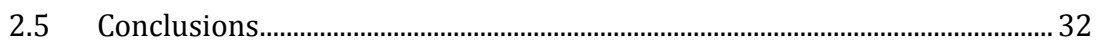

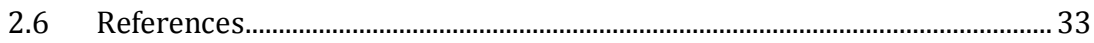

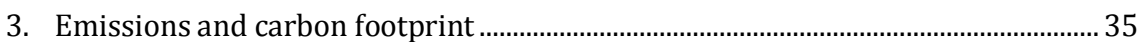

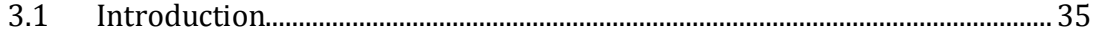

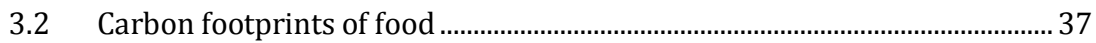

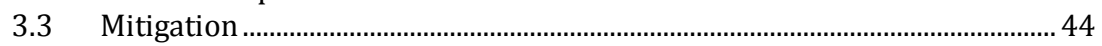

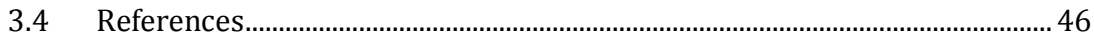

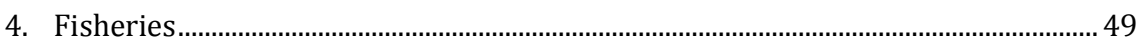

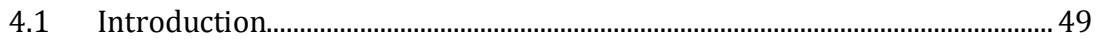

4.2 Projections of future ocean climate variations .................................................. 49

4.3 Fish and fisheries responses to past and recent climate variability ............52

4.4 Fish and fisheries responses to future climate change ................................... 58

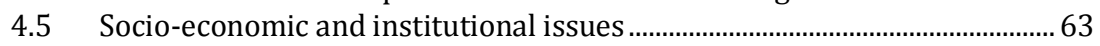

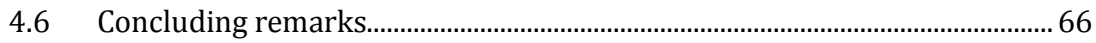

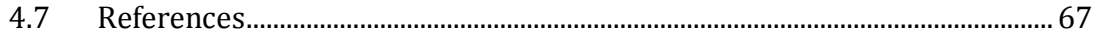

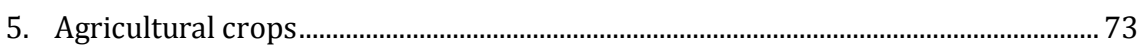

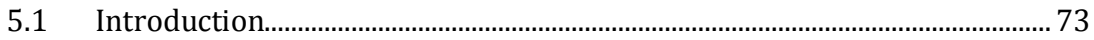

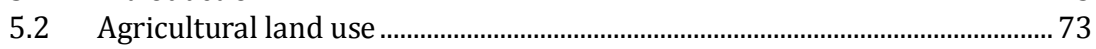

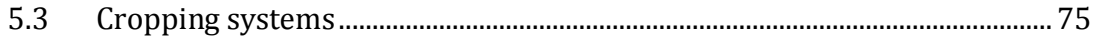

5.4 Observed changes..................................................................................................... 76

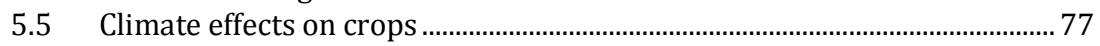

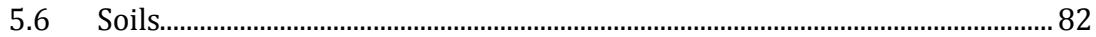

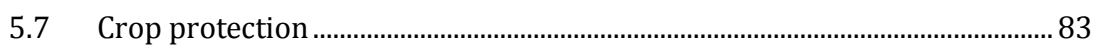

5.8 Extreme events and climatic variability............................................................ 84

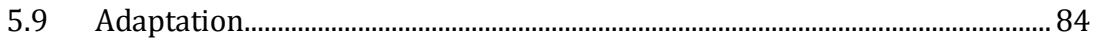

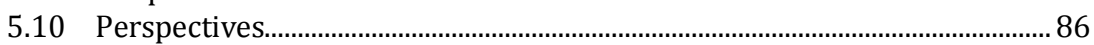

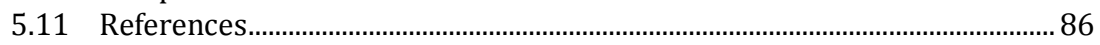




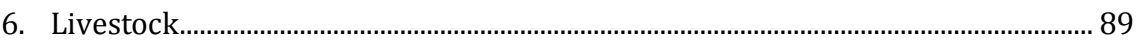

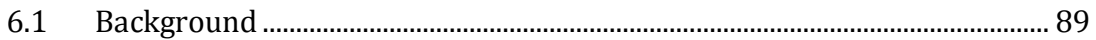

6.2 Climate change effects on livestock production............................................. 90

6.3 Mitigation of and adaptation to climate change............................................. 93

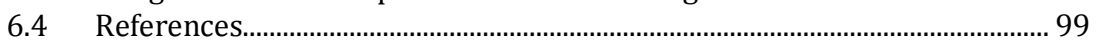

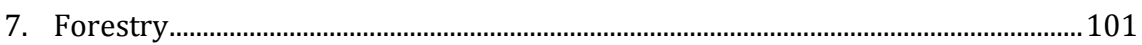

7.1 Introduction .............................................................................................. 101

7.2 Observed changes in and impacts of climate change on forest

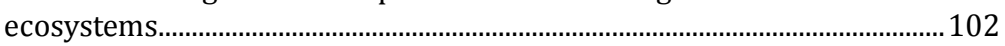

7.3 Climate change-induced risks to forests .....................................................110

7.4 Adaptation to and mitigation of climate change in forests ..........................112

7.5 References......................................................................................................115

8. Plant and animal health and food safety .................................................................. 117

8.1 Introduction - health impacts of climatic factors..........................................117

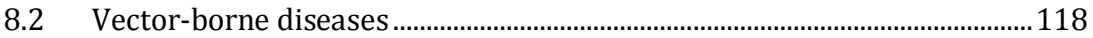

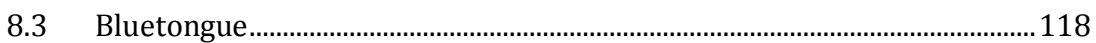

8.4 Tick-borne diseases...........................................................................................120

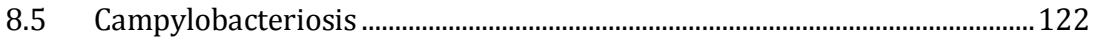

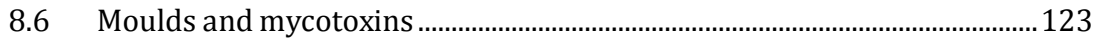

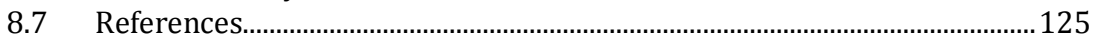

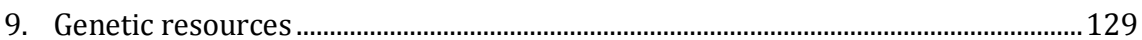

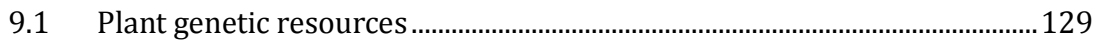

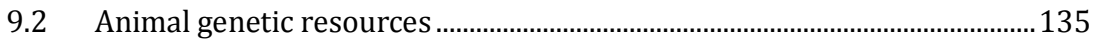

9.3 Mitigation and adaptation require robust animals .......................................135

9.4 Available animal genetic resources ............................................................137

9.5 Genetic resources in fish populations...........................................................140

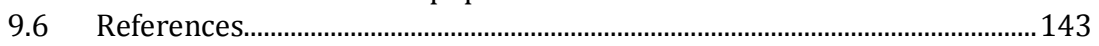

10. Bioeconomy ................................................................................................................. 149

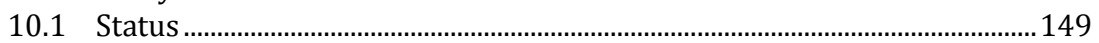

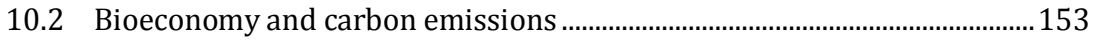

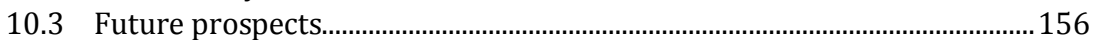

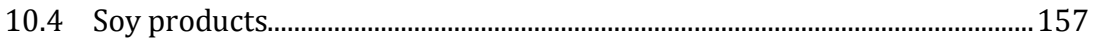

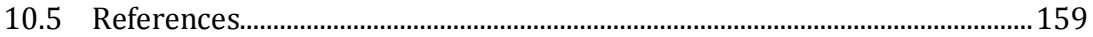

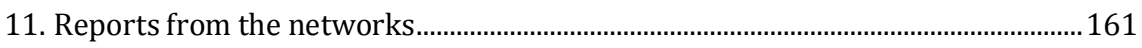

11.1 Network 1: Sustainable primary production in a changing climate ..........161

11.2 Network 2: Forest Soil Carbon Sink Nordic Network ...................................163

11.3 Network 3: Climate impacts on fish, fishery industry and management in the Nordic Seas..........................................................................168

11.4 Network 4: Nordic research network on animal genetic resources in the adaptation to climate change - AnGR-NordicNET .............................175

11.5 Network 5: Nordic Forage Crops Genetic Resource Adaptation Network NOFOCGRAN.................................................................................... 182

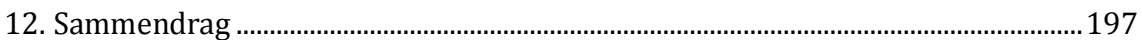




\section{Contributors to the report}

The following persons have contributed to the report:

\section{The steering committee}

- Jørgen E. Olesen, Aarhus University, Denmark (chair)

- Olafur S. Astthorsson, Marine Research Institute, Iceland

- Árni Bragason, Nordic Genetic Resource Center, Sweden

- Jorun Jarp, Norwegian Veterinary Institute, Norway

- Daði Már Kristófersson, University of Iceland, Iceland

- Kari Mielikäinen, Finnish Forest Research Institute (METLA), Finland

- Geir Oddsson, Nordic Council of Ministers, Denmark

- Andreas Stokseth, Ministry of Trade, Industry and Fisheries, Norway

\section{The network leaders}

- Rikke Bagger Jørgensen: Sustainable Primary Production in a Changing Climate

- Per Gundersen: Forest Soil C Sink Nordic Network

- Jan Erik Stiansen: Climate Impacts on Fish, Fishery Industry and Management in the Nordic Seas

- Theo Meuwissen: Nordic Research Network on Animal Genetic Resources in the Adaptation to Climate Change

- Odd Arne Rognli: Nordic Forage Crops Genetic Resources Adaptation Network (NOFOCGRAN)

- Sigurdur Gudjonsson: Arctic char: a species under threat and with great potentials in the age of climate change (NORDCHAR)

\section{The authors}

- Sepul Kanti Barua, Indufor Oy, Finland, Chapter 7

- Peer Berg, NordGen Farm Animals - The Nordic Genetic Resource Center, Norway, Chapter 6, Chapter 9

- Annegrete Bruvoll, Vista Analysis AS, Norway, Chapter 3, Chapter 10

- Christel Cederberg, Chalmers University of Technology, Sweden, Chapter 3, Chapter 10 
- Kenneth F. Drinkwater, Institute of Marine Research, Bergen, Norway, Chapter 4

- Arne Eide, Faculty of Biosciences, Fisheries and Economics / Norwegian College of Fishery Science, University of Tromsø, Norway, Chapter 4

- Emma Eythorsdottir, Faculty of Land and Animal Resources, Agricultural University of Iceland, Iceland, Chapter 6, Chapter 9

- Sigurður Guðjónsson, Institute of Freshwater Fisheries, Iceland, Chapter 4, Chapter 9, Chapter 11.5

- Leo A. Gudmundsson, Institute of Freshwater Fisheries, Iceland, Chapter 4, Chapter 9

- Per Gundersen, Department of Geosciences and natural Resource Management, University of Copenhagen, Denmark, Chapter 11.2

- Alf Håkon Hoel, Institute of Marine Research, Tromsø, Norway, Chapter 4

- Jorun Jarp, Norwegian Veterinary Institute, Norway, Chapter 8

- Rikke Bagger Jørgensen, Technical University of Denmark, Denmark, Chapter 9, Chapter 11.1

- Juha Kantanen, University of Eastern Finland, Finland, Chapter 6, Chapter 9

- Anne Kettunen-Præbel, NordGen Farm Animals - The Nordic Genetic Resource Center, Norway, Chapter 6, Chapter 9

- Peter Løvendahl, Department of Molecular Biology and Genetics, Aarhus University, Denmark, Chapter 6, Chapter 9

- Theo Meuwissen, NMBU Norwegian University of Life Sciences, Norway, Chapter 6, Chapter 9, Chapter 11.4

- Jørgen E. Olesen, Aarhus University, Denmark, Chapter 5

- Anders Portin, Indufor Oy, Finland, Chapter 7

- Odd Arne Rognli, NMBU Norwegian University of Life Sciences, Norway, Chapter 9, Chapter 11.5

- Jan Erik Stiansen, Institute of Marine Research, Norway, Chapter 4, Chapter 11.3

- Erling Strandberg, Department of Animal Breeding and Genetics, Swedish University of Agricultural Sciences, Sweden, Chapter 6

- Borgar Aamaas, Center for International Climate and Environmental Research - Oslo CICERO, Norway, Chapter 2 


\section{Preface}

Climate change will have considerable and complicated impacts on the Nordic Primary Industries. The Nordic countries are very much aware that although climate change is a global issue it has local consequences and the impacts need to be addressed locally. The Nordic countries have been among the leaders in addressing adaptation and mitigation of climate change in all its complexity both locally and globally.

In the light of this it is my pleasure to be able to present the final report and policy recommendations of the research programme, Climate Change Impacts, Adaptation and Mitigation in Nordic Primary Industries, the first attempt to comprehensively evaluate the impacts of climate change on the Nordic primary industries. The programme was developed and implemented in cooperation with NordForsk and has been active between 2010 and 2014 .

The report states that it is expected that climate change will have significant impact on living natural resources on land and in the sea, and thereby have significant impacts on fisheries, agriculture and forestry in the Nordic region. Climate change impacts present serious threats to ecosystems that need to be addressed, but on the other hand the anticipated changes present opportunities for new land and marine based production systems within the framework of the sustainable bioeconomy. The foreseen climate changes furthermore pose serious challenges for political decision making processes and natural resource management.

Climate change challenges the existing knowledge on natural resources in the Nordic region. There is a need to focus on research that supports decision making processes for new policies, new policy instruments. We need new thinking to address these challenges, but we also need to continue to support better monitoring systems, research strategies and international cooperation. 
The report and policy recommendations provide a baseline and a way forward, a focus for the activities that can help the Nordic region to address the threats and opportunities of climate change for our primary production systems.

I would like to thank the extensive Nordic networks that have done the heavy lifting behind this report and policy recommendation.

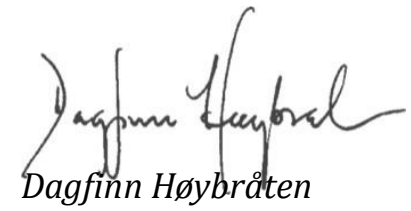

Secretary General

Nordic Council of Ministers 


\section{Summary}

The global demand for high-quality foods such as meat and fish is projected to greatly increase as a consequence of a rise in global wealth and a rapidly growing middle class, leading to nearly a doubling of demand by 2050. This will lead to corresponding increases in emissions of biogenic greenhouse gases (GHG) $\left(\mathrm{CO}_{2}\right.$, methane and nitrous oxide) from crop and livestock production as well as from fossil fuels used in the primary industries unless new technologies and management schemes to reduce emissions are developed.

The agriculture industry dominates GHG emissions from the primary industries in the Nordic countries. Emissions from the primary sector vary roughly between $5 \%$ of total national GHG emissions in Iceland to more than $20 \%$ of total national GHG emissions in Denmark. Globally, fisheries and shipping contribute $1-2 \%$ of the emissions of $\mathrm{CO}_{2}$. On the other hand, Nordic forests capture as much as $43 \%$ of total carbon emissions in increasing biomass.

The projected temperature increase towards the end of the 21st century depends largely on future emissions. With the current trend in emissions, the global mean temperature is projected to increase by $2.6^{\circ} \mathrm{C}$ to $4.8{ }^{\circ} \mathrm{C}$, and with lower emissions by $1.4{ }^{\circ} \mathrm{C}$ to $3.1^{\circ} \mathrm{C}$. The warming in the Nordic region will be similar to the global mean in the south and west and nearly double this in the north and east. The increase will be greatest in winter and in areas with a continental climate. More and heavier extreme precipitation events are expected, while change in wind conditions is uncertain. Warm water transported northwards with the North Atlantic Current may decrease by $20-30 \%$ by the end of the century. The warming will also reduce snow and ice cover. It is estimated that by the end of the century the duration of snow cover will be reduced by 1-3 months throughout the region, although changes in thickness may vary.

The Nordic region is the only place on earth where climatic conditions allow productive agriculture, forestry and fisheries at high latitudes with dark winters. The high latitudes are projected to warm at a higher rate than the global average. This will lead to winter conditions outside of those currently known and understood. The effects of such changes are difficult - if not impossible - to predict, and there is little research or evidence on which to base assessments of potential 
effects on the functioning of ecosystems and how this will affect productivity and management in agriculture, forestry and fisheries.

Soils in the Nordic region generally have carbon contents that are considerably higher than in other parts of Europe. An increase in temperature will enhance the decomposition of soil organic matter, which in turn may increase the supply of nitrogen in both agricultural and forest ecosystems. In forestry systems, this enhancement of nutrient turnover, together with the prolonging of the growing season, will boost forest growth, timber yield and carbon sequestration. The carbon sequestration rate in biomass is expected to increase steadily as well, as a consequence of higher atmospheric $\mathrm{CO}_{2}$ concentrations. However, changes in soil carbon in agricultural and forest soils are uncertain.

The most prominent impact of climatic warming in the Nordic region will probably be spatial shifts in ecosystem and species ranges and resultant changes in the suitability of production systems for agriculture, forestry and fisheries.

The warming will affect phytoplankton production in the ocean which, along with changes in sea temperature and salinity, will lead to shifts in distribution and production of major marine fish species. Different fish species will tend to move northwards at different rates, thereby altering the overlap between predators, prey and competitors. This will lead to new interactions between species, which will in turn affect stock productivity. Changes in location and migrations of fish stocks may also put pressure on existing agreements on fish stock sharing or necessitate entirely new ones. Freshwater fish species will also be subject to changes in range distribution, which will affect the use of these species in commercial and recreational fisheries.

Agricultural crops and cropping systems will experience a substantial northward expansion, leading to an increase in productivity and a wider selection of crops being grown in most regions, provided that the terrain and soils are suitable. Forestry will see a shift in the suitability of tree species at higher latitudes and higher elevations in mountainous terrain. The extension of the growing season is also expected to enhance the growth and productivity of forests in the Nordic region.

While climate change provides improved conditions for agriculture, forestry and fisheries in the Nordic countries, it will also give rise to new risks associated with biotic and abiotic stresses to plants and animals. Increased inter-annual variability and higher frequency of extreme weather events such as heat waves, droughts, storms and intense and persistent rainfall will mean new and changed threats to production systems. In agriculture, this will affect not only crops but also livestock 
production, partly in relation to feed availability and partly as a result of the effects of heat stress on animals. In forestry, the risk of fire and damage due to wind and storms are expected to increase. The risk of outbreaks of pests and diseases causing defoliation, growth loss, timber damage and even massive forest dieback may increase as well. In freshwater systems, weather extremes, such as floods and droughts, can decrease recruitment and survival of fish.

The warming will not only affect plants and animals on which the primary industries depend, but also the suitability of pests and diseases that thrive on these. This will in turn affect crop production, where it will be necessary to cope with new species of weeds, pests and diseases that are better adapted to warmer conditions. In general, the need to control these will call for new approaches to avoid increased use of pesticides. In addition, livestock production will need to cope with new and changed vector- and food-borne diseases adapted to the changed climatic conditions. Some of these diseases may also be transmitted between humans and animals, which means, close surveillance will be essential.

Giving consideration to adaptation is particularly important where there are long lead times before new technologies, materials or management schemes can be implemented or where the involvement of several actors or institutions is required. This is a particular concern in land-use planning and management, use of genetic resources for both plants and animals, and management and prevention of plant and animal disease. These areas of concern will therefore need particular attention to ensure that government planning and incentive structures are well aligned with the needs of private actors to facilitate efficient adaptation. When developing new technologies and management measures for adapting to climate change, consideration should also be given to the need to reduce GHG emissions and increase carbon capture for sequestration and feeding the bio-based society. 



\section{Introduction}

\subsection{Background for the programme}

The research programme Climate Change Impacts, Adaptation and Mitigation in Nordic Primary Industries is a thematic, network-based research programme established by the Nordic Council of Ministers as part of its globalisation agenda. It was launched at a meeting of the Nordic prime ministers in Punkaharju, Finland, in June 2007.

The programme was developed in collaboration with NordForsk, which hosts the programme secretariat. NordForsk is an independent body for research and education under the Nordic Council of Ministers of Education and Research. The organisation facilitates cooperation between the five Nordic countries when this will add value to activities being conducted.

The programme has its origins in concerns about the profound impact that climate change is expected to have on natural resources and hence on the primary industries in the Nordic region. Climate change induces risks and generates opportunities for production systems on land as well as at sea. This represents a great challenge in relation to policy-making and management. Climate change has thus given rise to a need to improve the knowledge base in the Nordic region.

Climate change is by nature global and cross-sectoral and will require a broad-based approach. In the long term, climate change is expected to have major societal consequences about which little is known. An optimal knowledge base for formulating initiatives and adaptations to address anticipated climate change is of vital importance for the sectors involved. There is a great need for policy-oriented research that can promote and be utilised for the development of monitoring systems, research strategies, international cooperation and political instruments.

The programme's overall objective is to create a Nordic knowledge base on climate change impacts in the Nordic region. This knowledge will provide a basis for the development of an adaptation policy for relevant areas in the individual Nordic countries and for the Nordic region as a whole. The programme is targeted towards the Nordic region and the need for advice that can contribute to the development of an over- 
arching climate policy for the region. The results of the programme will be used in the preparation of climate policy within the relevant areas.

\subsection{Research funding}

The programme had a budget of about NOK 18 million for the core period 2011-2013. Projects were required to provide self-financing of minimum $60 \%$ of the total budget. Funded projects were required to involve collaboration between at least three Nordic countries, or between at least two Nordic countries and one Baltic country.

As a general principle, funded activities are to support genuine Nordic cooperation, enhance relevant national activities and add important Nordic dimensions. The programme has five themes encompassing the main Nordic production systems of fisheries, agriculture, forestry and food:

- Plant and animal health (cross-sector theme).

- Conservation, adaptation and utilisation of genetic resources (crosssector theme).

- Adaptation and mitigation in milk, meat and cereal production systems (sector-specific theme).

- Impacts and adaptation in fish production systems (sector-specific theme).

- Sustainable biomass production and carbon storage in terrestrial ecosystems (sector-specific theme).

\subsection{The networks}

Two calls for proposals, issued in 2009 and 2010 respectively, resulted in the funding of the six following networks under the programme:

\section{Network 1: Sustainable Primary Production in a Changing Climate}

The aim of the network is to develop common and regionally tailored measures and strategies, plant material and decision-making tools. The main objectives are plant health, conservation, adaptation and utilisation of genetic resources, adaptation and mitigation in the cereal production system, and sustainable biomass production.

Networking between the participants and their already ongoing major national and international projects on climate change is fundamental 
for joint activities on researcher training, research and development of agricultural strategy. Researchers and plant breeders collaborate closely to help to prepare Nordic society for future climate change. Plant genetic resources, mainly from NordGen, are selected on the basis of realistic future scenarios.

The results will be used to provide decision support tools for a future sustainable, stable and safe primary production of food, feed and bioenergy.

The network has published four articles in peer-reviewed journals, and eight articles are in preparation or have been submitted.

\section{Network 2: Forest Soil C Sink Nordic Network}

Forests cover $60 \%$ of the land area in the five Nordic countries, and forestry is one of the most important primary industries in the Nordic region. These forests store massive amounts of carbon in soil organic matter, and it is important to protect and possibly enhance this storage through forest management.

The aim of the network is to increase understanding of factors affecting accumulation or loss of soil organic matter. Research activities examine in particular the potential impacts on soil carbon sequestration of increased bioenergy harvesting from forests, nitrogen deposition that appears to increase carbon accumulation, afforestation or natural regrowth of forests after cessation of agricultural use, and reconstruction of forest drainage infrastructure. By combining databases on soil carbon content in forests, long-term forest management experiments and mathematical simulation models, the network helps to improve understanding within the area of soil carbon sequestration.

The results will be used to advise the forestry sector on best management practices and strategies for protecting and increasing the carbon sink of soils.

\section{Network 3: Nordic network: Climate impacts on fish, fishery industry and management in the Nordic Seas}

A consortium of 13 Nordic institutions have joined forces in this network with the objective of conducting research on the effects of climate change on the distribution and abundance of marine fish stocks in the Nordic Seas, with emphasis on pelagic stocks in the Norwegian Sea. The network is also dedicated to investigating fisheries management issues as well as the economic and societal consequences of the anticipated changes in the fish stocks for the fishing industry and local communities. An important issue is how potential changes in fish stocks that cross national boundaries will affect fish treaties and international relations. 
The network provides interdisciplinary studies on the link between physical climate systems, geographical distribution of fish, and effects on the management systems and economic potential for harvesting. Understanding these links will provide a strong basis for developing sound, long-term fisheries management and policy capable of effective adaptation to and mitigation of future climate change.

The project has published 41 articles in peer-reviewed journals, four articles are in preparation or have been submitted, and one Ph.D. thesis and five Master's theses have been completed.

\section{Network 4: Nordic Research Network on Animal Genetic Resources in the Adaptation to Climate Change}

Livestock production contributes to and will be affected by climate change, and domestic animal genetic resources for food and agriculture have not yet been properly integrated into strategies on the impacts of climate change on primary industries and adaptation. Increased accessibility to a wide diversity of animal genetic resources will be needed in order to increase the sustainability of animal production systems and strengthen food security in light of the effects of climate change.

The network is helping to develop a Nordic knowledge base for policy-making for the conservation, utilisation and investigation of animal genetic resources in the context of adaptation and mitigation issues. The network has compiled current knowledge of climate change effects on primary industries, especially on Nordic agroecosystems and livestock production.

The network has published, or submitted, a total of 17 articles in peer-reviewed journals.

\section{Network 5: Nordic Forage Crops Genetic Resource Adaptation Network (NOFOCGRAN)}

In the Nordic countries, a major proportion of agricultural land is used for forage production. The dominating crops are perennial grasses and legumes. Climate change constitutes a great challenge for perennial plants. Improved, adapted and high-yielding cultivars with good quality and disease resistance are key elements for ensuring sustainable agriculture in the Nordic region.

The network brings together experts in plant genetics, plant physiology, crop modelling and plant breeding from three Nordic countries, all of whom are engaged in ongoing national and international activities related to Nordic forage production and the adaptation of perennial forage crops to a changing climate. The objective of the network is to develop knowledge, methods and germplasm as the basis for future develop- 
ment of cultivars of perennial forage grasses and legumes adapted to the expected changes in climate.

\section{Network 6: Arctic char: A species under threat and with great potential in the age of climate change (NORDCHAR)}

The Arctic char is a species under threat, and is well-suited for use as a model species for monitoring changes in the Nordic areas due to climate change.

The aim of the NORDCHAR project is to use new genetic methodologies as well as conventional life history ecology methods to promote model-based analyses on the effects of climate change as a valuable resource for the Nordic countries. The network focuses on threats as well as opportunities linked to climate change. Leading scientists in freshwater ecology and genetics from each participating country have joined forces to add value to the available data on Arctic char as well as to produce new data.

The aim is to use the results for policy-making for the fish farming industry, the recreational fishing industry, genetic resource preservation, conservation strategies and the management authorities. 



\section{Climate and climate change in the Nordic countries}

\subsection{Introduction}

This chapter provides an introduction to the climate of the Nordic countries (see Figure 2.1) as well as an overview of past climatic variations and estimates of future changes.

Climate comprises the slowly varying aspects of the atmospherehydrosphere-land system and is characterised statistically in terms of long-term (typically 30-year) averages and variability of climate elements such as temperature, precipitation, winds, etc. Climate variability is the temporal variation around this average state with timescales of months to millennia. Natural climate variability occurs due to factors such as changes in solar radiation, volcanic eruptions, or internal dynamics within the climate system. Human effects on climate, such as those caused by GHG emissions or land use, are termed anthropogenic influences. Climate change is any systematic change in the long-term statistics of climate elements from one state to another, where the new state is sustained over several decades or longer. In recent years, the term climate change has often been used exclusively to refer to those causes arising directly or indirectly from human activity alone and in this sense has been used interchangeably with global warming.

Warming of the climate system is unequivocal, and since the 1950s, many distinct changes have been observed. Changes in the atmosphere, ocean, snow and ice conditions, sea level and GHG concentrations are all consistent with human-made global warming (IPCC 2013). According to the IPCC, it is extremely likely ( $>95 \%$ ) that human influence has been the dominant cause of the observed warming since 1950. 


\subsection{The climate of the Nordic region}

The most important factor for the climate in the Nordic region is the region's geographical position on the western coastal zone of the Eurasian continent (Tveito et al. 2000). The region has both a maritime and continental climate, depending on the direction of the air flow. The further east, the more continental the climate is.

The main wind direction is westerly, bringing mild airflows from the Atlantic Ocean to the Nordic region in winter. The ocean currents off the coast of Western Europe, named the Norwegian Atlantic Current west of Norway, carry warm and salty waters in relation to their latitude as they are remnants of the warm Gulf Stream. The Nordic region is heated by these mild currents. On the other side of the Nordic Seas, the East Greenland Current transports cold water and sea ice southwards and towards Iceland. Hence, the Nordic region is the warmest area this far north. The average temperature is several degrees higher than in any other areas at the same latitude. The northernmost ice edge is on the west coast of Svalbard. In addition, the open waters of the Baltic Sea and large lakes contribute to mild winters. The climate in the Nordic region can periodically be continental as easterly winds bring dry air from the Eurasian continent. Such events cause cold periods during winter and hot periods during summer.

Another important factor for the climate in the Nordic region is the polar front, where warm subtropical and cold polar air masses meet. This front is normally situated over the Nordic region, moving southwards during winter and northwards during summer. The temperature difference between these two air masses is especially great during winter, which can cause large fluctuations in temperature as the polar front often moves in waves.

According to the Köppen climate classification, most of the mainland of the Nordic region belongs to the temperate coniferous-mixed forest zone with cold, wet winters. Greenland, Svalbard, parts of Iceland, the very northeastern tip of Norway, as well as the highest mountains in Norway and Sweden have a polar climate. On the other side, the west coast of Denmark, Sweden and Norway fall under the maritime temperate climate. Most of the ocean area has this maritime climate as well.

Since the Nordic region is situated far north, the seasons are very distinct. The winters are dark with very short days, while summers are light with almost no night. North of the Arctic Circle (66 $\left.33^{\prime} \mathrm{N}\right)$, the sun is continuously under the horizon during winter solstice and continuously over the horizon during summer solstice. Since the days are long in 
summer, the daily incoming solar radiation is comparable to more southerly locations even though the sun is always low on the horizon.

Figure 2.1: The Nordic region seen from the North Pole

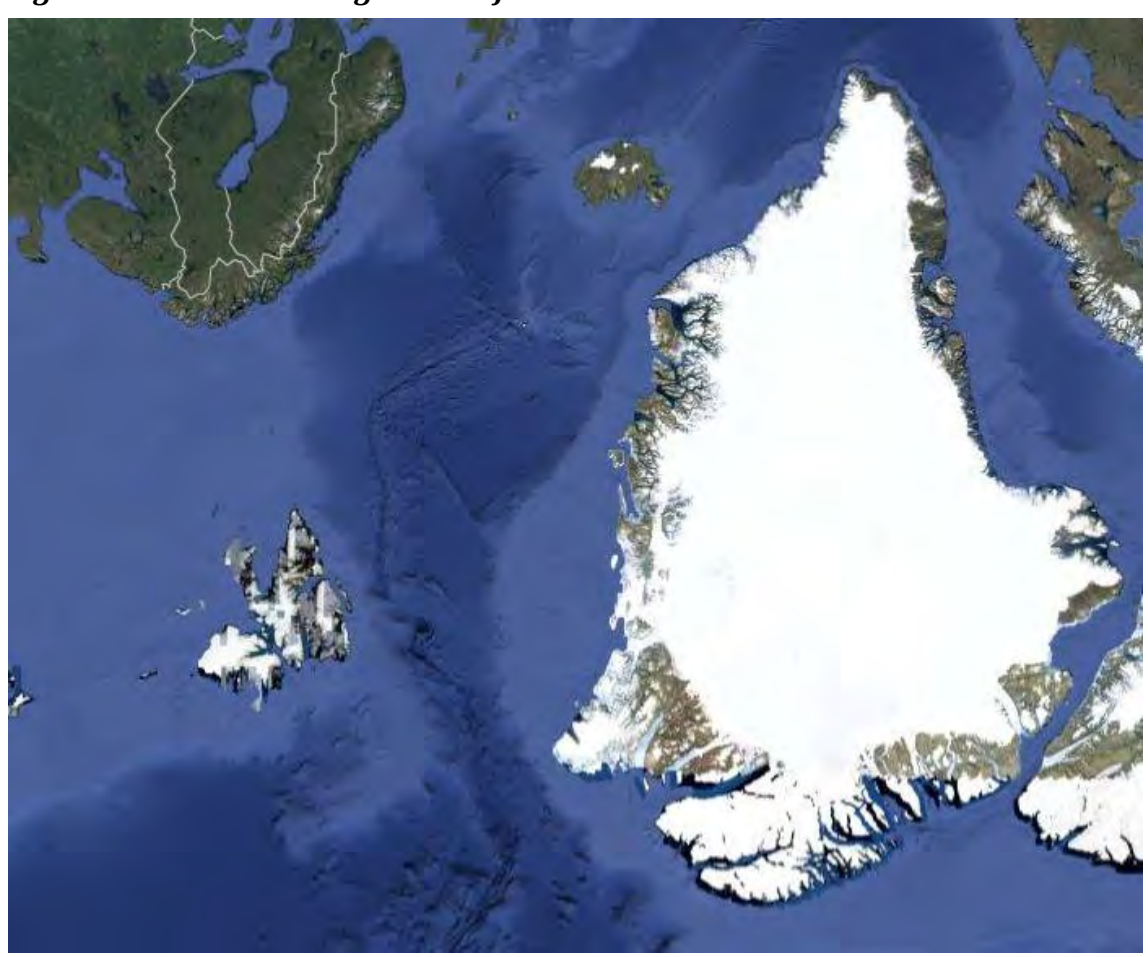

Source: Google Maps.

\subsection{Impacts of climate change in the Nordic region}

The Nordic region is affected by both natural and human-made climate change and variations. Examples of natural climate change include shifts between ice ages and warmer interglacial periods, multicentennial changes such as the "Medieval Warm Period" (890-1170 AD) and "Little Ice Age" (1580-1850 AD) (Osborn and Briffa 2006), and multidecadal scales such as the Atlantic Multidecadal Oscillation (AMO) (Kerr 2000). The AMO is the variability in the North Atlantic sea surface temperatures (SSTs) within a 60-80 year period that includes cool periods in the early 1900 s and the 1970s to mid-1990s and warm periods in the 1920 s to 1960s and the mid-1990s to present. The AMO fits within the definition of climate change as it is multidecadal, but it is actually an example of longer-term climate variability. Another example of climate variability includes the strong decadal fluctuations associated with changes in the 
North Atlantic Oscillation (NAO). The NAO is related to changes in the subpolar (Icelandic) Low and the subtropic (Azores) High, which tend to intensify or weaken at the same time (Hurrell 1995). In the positive NAO phase, stronger southerly flows produce warmer than normal air and sea temperatures and higher precipitation over Northern Europe, including the Barents Sea, whereas the northerly winds between Eastern Canada and Greenland cause cooler than normal air temperatures and drier conditions there. The mild and wet weather in the Nordic region in December 2013 was an example of this positive NAO. The opposite pattern occurs during the negative phase of the NAO.

Climate changes resulting from increased atmospheric GHGs generate a small but steady temperature increase, which accumulates over the years and eventually produces a significant rise throughout the globe. This is especially noticeable in the Arctic, where the rate of change in temperature is double that of the global average. In the short term, changes from natural variability are much larger than the anthropogenic-induced changes, which may be undetected. There may be times in the future when cooling caused by natural variability will dominate the rise in temperature from anthropogenic effects, and such conditions may last for several years or even decades. This does not mean the end of anthropogenic warming, because it will ultimately prevail and temperatures are expected to rise well above present-day values. Natural variability will always occur, however.

The global surface temperature increase since 1901 is $0.89^{\circ} \mathrm{C}$ (IPCC 2013). Each of the last three decades has been warmer than all of the previous decades in the instrumental record. Since 1951, the decadal warming has been $0.12{ }^{\circ} \mathrm{C}$ per decade. The global sea surface temperature has increased by $0.07{ }^{\circ} \mathrm{C}$ per decade during the same period. The confidence in observed precipitation changes is smaller, but an increase in precipitation in the Northern Hemisphere's mid-latitude land areas has been observed since 1900. An increase has also been seen in the high latitudes of the Northern Hemisphere since 1951, but the confidence in this result is low due to the low number of measuring stations. The number of cold days and nights has decreased, with an increase in the number of warm days and nights since 1950. As expected, the increase is larger for minimum temperature extremes than maximum temperature extremes. Further, the number of heavy precipitation events over land has likely increased during the same period as well. In Europe, the increase has been greatest during winter.

Circulation features such as storm tracks and the jet stream, as well as a contraction of the northern polar vortex, have moved northwards 
since the 1970s. Studies show that the Atlantic cyclone activity during the past 60 years has shifted northwards and eastwards. The wintertime cyclones are more frequent and more intense in the high-latitude Atlantic and less frequent in the mid-latitude Atlantic. An increase in westerly winds in the northern mid-latitude as well as an increase in the NAO index was observed from the 1950s to the 1990s, which gives wetter and milder winters in the Nordic region. This increase in pressure differences observed in the 1980s and 1990s was followed by a decrease to the long-term mean state in the 2000s. Confidence in other long-term global circulation changes, such as surface winds over land, is low.

The temperature increase both globally and in the Northern Hemisphere mainly occurred in two periods, from 1900 to around 1940 and from 1970 to 2000 (Figure 2.2). The warming early in the 20th century happened largely in the mid and high latitudes of the Northern Hemisphere. The same trend has been observed in the Nordic countries, but with some variation. The warm periods in the 1930s were more pronounced in the northern and western part of the Nordic region than the southern and eastern part.

The Arctic sea ice extent has decreased. Since the first satellite observations in 1979, the summer minimum extent of Arctic sea ice (in September) has decreased by about $11.5 \%$ each decade. The decrease has also been observed in winter, but to a lesser degree. The average winter sea ice thickness has decreased, with a large drop in the amount of multiyear ice. Almost all glaciers have shrunk, including in the Nordic region. The melting of the Greenland Ice Sheet is accelerating, and the melting in the 2002-2011 period was $215 \mathrm{Gt} / \mathrm{yr}$ or $0.59 \mathrm{~mm} / \mathrm{yr}$ sea-level equivalent. The snow cover extent has decreased in the Northern Hemisphere, especially in spring. Freshwater lakes in the Northern Hemisphere freeze up later than before, while breakup is earlier. Permafrost temperatures have been increasing in most regions, while the depth of the seasonally frozen ground has also changed. 
Figure 2.2: Changes in surface temperature

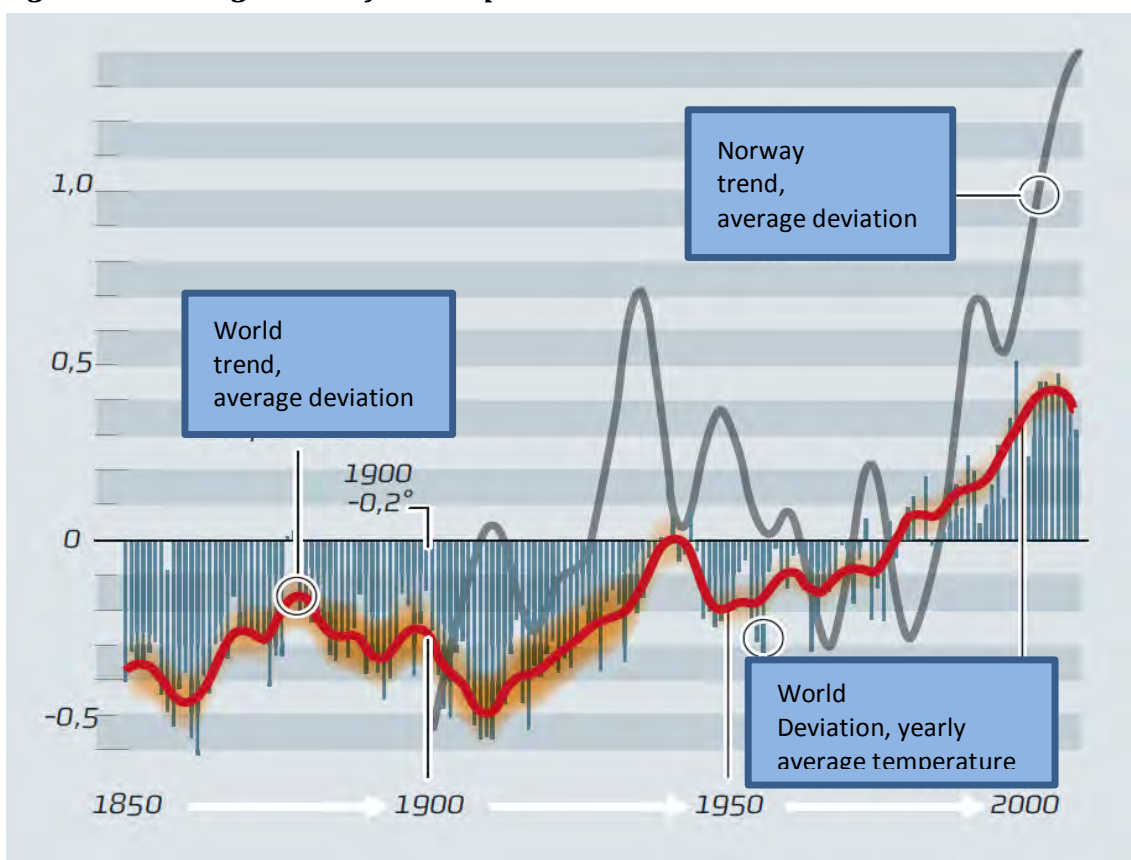

Red line: Global. Grey line: Norway.

Source: Bjørnæs (2010).

\subsection{Nordic climate in the future}

The future climate in the Nordic region will depend on a number of factors with considerable uncertainties. For long-term climate change, the greatest uncertainty is associated with the level of future emissions. A number of scenarios have been selected to illustrate possible emissions in the future. Emission scenarios and climate projections from IPCC (2007) and IPCC (2013) are presented below. Generally, the predictions are more certain for global conditions than for conditions in a small region such as the Nordic countries.

\subsubsection{Emission scenarios}

The emissions scenarios in AR4 (IPCC 2007) are based on the Special Report on Emissions Scenarios (SRES) (IPCC 2000). These scenarios are based on economic activity, population growth, and technological improvements and implementations in the 2000-2100 period. The three main scenarios can be defined as low (B1), middle (A1B), and high sce- 
narios (A2) with regard to emissions and climate change. The focus here is on the middle scenario.

\subsubsection{Emission pathways}

The new generation of scenarios, Representative Concentration Pathways (RCPs), are not scenarios, but pathways indicating possible emissions (IPCC 2013). The four RCPs are named according to their impact on radiative forcing in 2100. Radiative forcing is a measure of potential climate change. The pathway similar to business-as-usual gives a radiative forcing of $8.5 \mathrm{~W} / \mathrm{m}^{2}$ in 2100 , thus the name RCP8.5. This pathway gives the most dramatic climate change. On the other end, RCP2.6 indicates how a warming of less than $2{ }^{\circ} \mathrm{C}$ is possible. RCP4.5 and RCP 6.0 are pathways in the middle. The main focus here is on RCP4.5; however, RCP6.0 is the pathway that is closest to the scenario A1B.

\subsubsection{Climate projections in IPCC 2007}

The global temperature increase from 2011 to 2030 compared to 1980 to 1999 is estimated to be in the range $+0.64{ }^{\circ} \mathrm{C}$ to $+0.69{ }^{\circ} \mathrm{C}$. Most of the warming is due to emissions that have already been emitted, and the differences between the scenarios are small at the beginning of the period. From 2046 to 2065 , the global temperature increase is $+1.8^{\circ} \mathrm{C}$ for the A1B scenario, but somewhat smaller for the low emission scenario. About a third of this warming has already taken place. By the end of the century (2090-2099), the temperature increase is predicted to be $+2.8^{\circ} \mathrm{C}$, ranging between $+1.7^{\circ} \mathrm{C}$ and $+4.4{ }^{\circ} \mathrm{C}$ when uncertainty range is included. The low emission scenario, B1, predicts a temperature increase of $+1.8^{\circ} \mathrm{C}\left(1.1^{\circ} \mathrm{C}\right.$ to $\left.2.9^{\circ} \mathrm{C}\right)$, while the high emission scenario, $\mathrm{A} 2,+3.4^{\circ} \mathrm{C}\left(2.0^{\circ} \mathrm{C}\right.$ to $\left.5.4^{\circ} \mathrm{C}\right)$.

The predicted change in temperature and precipitation in Northern Europe for the different seasons from the 1980-1999 period to the 2080-2099 period is given in Table 2.1. In Northern Europe, the annual temperature change will likely be greater than globally $\left(3.2^{\circ} \mathrm{C}\right.$ compared to $2.8^{\circ} \mathrm{C}$ globally), with the largest temperature increase in winter $\left(4.3^{\circ} \mathrm{C}\right)$. In the Arctic, the annual temperature increase is predicted to be $5{ }^{\circ} \mathrm{C}$. Changes in atmospheric circulation have significant potential to affect temperature in Europe, but these changes will not be the main cause of the projected warming. The temperature variability in summer on interannual and daily timescales will likely increase in most areas. However, the temperature variability in winter is projected to decrease, on both interannual and daily timescales. In 
areas where snow cover is reduced, the minimum temperature increase will be largest. In addition, heat waves are predicted to increase in frequency, intensity and duration. On the other hand, the number of frost days will decrease.

Annual precipitation is very likely to increase in most of Northern Europe, with an increase generally north of $50{ }^{\circ} \mathrm{N}$. This increase will be due to circulation changes and thermodynamic factors. In a warmer climate, the air can hold and transport more moisture, thus giving more rain and snow. If the westerly winds increase in winter, which a majority of models predict, winter precipitation will increase. The precipitation increase for Northern Europe is largest in winter (+15\%) and smallest in summer $(+2 \%)$. When uncertainties are included, precipitation may even decrease in summer. A decrease in summer is typically predicted south of $55^{\circ} \mathrm{N}$ which includes most of Denmark.

Since a warmer climate leads to increased evaporation, this moves the line between wetter and drier climate (precipitation minus evaporation) northwards by a few hundred kilometres. Whether summer soil moisture will increase or decrease in the Nordic region is uncertain. Increased precipitation leads to wetter soil, while earlier snowmelt and increased evaporation leads to drier soil. The extremes of daily precipitation are very likely to increase, both in magnitude and frequency. Changes in precipitation may vary on relatively small horizontal scales in areas with complex topography, for instance along the west coast of Norway. This small-scale variability in precipitation may dominate over more general changes for larger areas.

\begin{tabular}{|c|c|c|c|c|}
\hline Parameter & Season & $25 \%$ quartile & Median response & $75 \%$ quartile \\
\hline \multirow[t]{5}{*}{ Temperature change $\left({ }^{\circ} \mathrm{C}\right)$} & Winter & 3.6 & 4.3 & 5.5 \\
\hline & Spring & 2.4 & 3.1 & 4.3 \\
\hline & Summer & 1.9 & 2.7 & 3.3 \\
\hline & Autumn & 2.6 & 2.9 & 4.2 \\
\hline & Annual & 2.7 & 3.2 & 4.5 \\
\hline \multirow[t]{5}{*}{ Precipitation change (\%) } & Winter & 13 & 15 & 22 \\
\hline & Spring & 8 & 12 & 15 \\
\hline & Summer & -5 & 2 & 7 \\
\hline & Autumn & 4 & 8 & 11 \\
\hline & Annual & 6 & 9 & 11 \\
\hline
\end{tabular}

Difference between the 2080-2099 period and the 1980-1999 period. The median response is the most likely response, while there is a $50 \%$ chance that the actual responses will be between the $25 \%$ and $75 \%$ quartile. 
The snow season will likely be 1-3 months shorter in Northern Europe, with a $50-100 \%$ decrease in snow depth in most areas by the end of the century. An increase in total winter precipitation may counteract and give deeper snow cover in some areas for shorter periods. Snow conditions in the coldest part, such as northern Scandinavia, are less sensitive to temperature and precipitation changes. The Baltic Sea is likely to lose a large share of its seasonal ice cover during this century. The climate models have underestimated the observed sea ice loss in the Arctic; thus, there is large uncertainty as to how fast the reduction of Arctic sea ice will take place.

The change in wind conditions in the Nordic region is uncertain, but more likely than not there will be an increase in average and extreme wind speeds in Northern Europe. A key factor for wind is the large-scale atmospheric circulation. Some models predict the north-south pressure gradient over Scandinavia will increase, causing stronger winds and a northward shift in cyclone activity. Other models show small changes in pressure gradients.

An earlier report goes into detail on how the individual countries in the Nordic region will be affected by a warming of $2{ }^{\circ} \mathrm{C}$ compared to a pre-industrial world (Aaheim et al. 2008). This temperature increase is smaller than that predicted by the A1B scenario by the end of the century, but the trends are similar. If warming is greater, the trends will be even more distinct. The temperature increase will in general be larger or slightly larger in the Nordic region than globally, with increasing sensitivity northward. Over the North Atlantic Ocean, the warming will be about half of the global warming.

In Denmark, the temperature increase will be close to the global temperature increase. The annual precipitation is not predicted to change much, but there will be more precipitation in winter and less in summer. In Finland, the temperature increase in summer will be slightly larger than the global annual increase, while the winter temperature increase will be roughly double the global increase. The precipitation increase is predicted to be similar to the general increase in Northern Europe (see Table 2.1). In Norway, the temperature increase will be largest in the northern part of the country and smallest along the west coast. Precipitation will increase in all regions during all seasons with the possible exception of a small decrease in summer in Eastern Norway. Climate changes in Sweden will be similar to those in Norway and Finland. The ocean around the Faroe Islands will dampen the temperature increase on those islands; hence, the increase will not be larger than the global temperature increase. Precipitation will increase more than the average 
for Northern Europe. The changes predicted for Iceland are similar, but the eastern side of the island has a slightly more continental climate and thus will experience a larger temperature increase.

\subsubsection{Climate projections in IPCC 2013}

Temperature and precipitation changes in the Nordic region are illustrated in Figures 2.3 and 2.4 respectively. Changes for the RCP4.5 pathway are shown for early, middle and late 21st century relative to the 1986-2005 period. The changes predicted in IPCC (2013) are similar to those predicted in IPCC (2007), but the findings presented in the previous section are found to be more robust.

The period from 1986 to 2005 was $0.61{ }^{\circ} \mathrm{C}$ warmer than the preindustrial level. The well-known target of avoiding an average global warming of $2{ }^{\circ} \mathrm{C}$ is in relation to the pre-industrial level; thus, this must be taken into account if the future conditions presented in this section are to be compared with pre-industrial conditions. The period from 2016 to 2035 is predicted to be $0.39^{\circ} \mathrm{C}$ to $0.87^{\circ} \mathrm{C}$ warmer globally, relative to 1986 to 2005. Predicted warming in the 2046-2065 period and the 2081-2100 period globally, over land, over the ocean and in the Arctic is shown in Table 2.2. The RCP4.5 pathway gives an increase in global temperature of $1.8^{\circ} \mathrm{C}$ from $2081-2100$ relative to $1986-2005$. Warming over land is a factor 1.4-1.7 higher than warming over the ocean. The largest warming will occur in the Arctic, fuelled by the snow albedo feedback. The Atlantic Meridional Overturning Circulation (AMOC), which is the pump that determines how much warm water is transported northwards with the Gulf Stream, will likely decrease by $20-30 \%$ by the end of the century according to RCP4.5. This weakening will slow down the warming slightly in the Nordic region.

Table 2.2: The temperature increase relative to $1986-2005$ predicted in the different RCPs. The uncertainties are given for one standard deviation

\begin{tabular}{lllll} 
& RCP2.6 & RCP4.5 & RCP6.0 & RCP8.5 \\
\hline Global, 2046-2065 & $1.0^{\circ} \mathrm{C} \pm 0.3$ & $1.4^{\circ} \mathrm{C} \pm 0.3$ & $1.3^{\circ} \mathrm{C} \pm 0.3$ & $2.0^{\circ} \mathrm{C} \pm 0.4$ \\
Global, 2081-2100 & $1.0^{\circ} \mathrm{C} \pm 0.4$ & $1.8^{\circ} \mathrm{C} \pm 0.5$ & $2.2^{\circ} \mathrm{C} \pm 0.5$ & $3.7^{\circ} \mathrm{C} \pm 0.7$ \\
Land, 2081-2100 & $1.2^{\circ} \mathrm{C} \pm 0.6$ & $2.4^{\circ} \mathrm{C} \pm 0.6$ & $3.0^{\circ} \mathrm{C} \pm 0.7$ & $4.8^{\circ} \mathrm{C} \pm 0.9$ \\
Ocean, 2081-2100 & $0.8^{\circ} \mathrm{C} \pm 0.4$ & $1.5^{\circ} \mathrm{C} \pm 0.4$ & $1.9^{\circ} \mathrm{C} \pm 0.4$ & $3.1^{\circ} \mathrm{C} \pm 0.6$ \\
Arctic, 2081-2100 & $2.2^{\circ} \mathrm{C} \pm 1.7$ & $4.2^{\circ} \mathrm{C} \pm 1.6$ & $5.2^{\circ} \mathrm{C} \pm 1.9$ & $8.3^{\circ} \mathrm{C} \pm 1.9$ \\
\hline
\end{tabular}

As a rule of thumb, global precipitation will increase by 1-3\% per degree in global temperature increase (IPCC 2013). The sea level pressure difference between the Arctic and the tropics will likely increase. In addition, the polar jet may shift northwards. These changes will tend to give more westerly 
winds and precipitation in the Nordic region. A shift to more intense individual storms is predicted, but at the expense of fewer weak storms. Snow cover extent during spring in the Northern Hemisphere will decrease by $13 \%$ according to RCP4.5 from the period 1986-2005 to the period 2081-2100. Some models predict that the Arctic will be ice-free in summer by 2040-2060, while other models predict a slower decrease in sea ice.

Figure 2.3: The predicted temperature changes

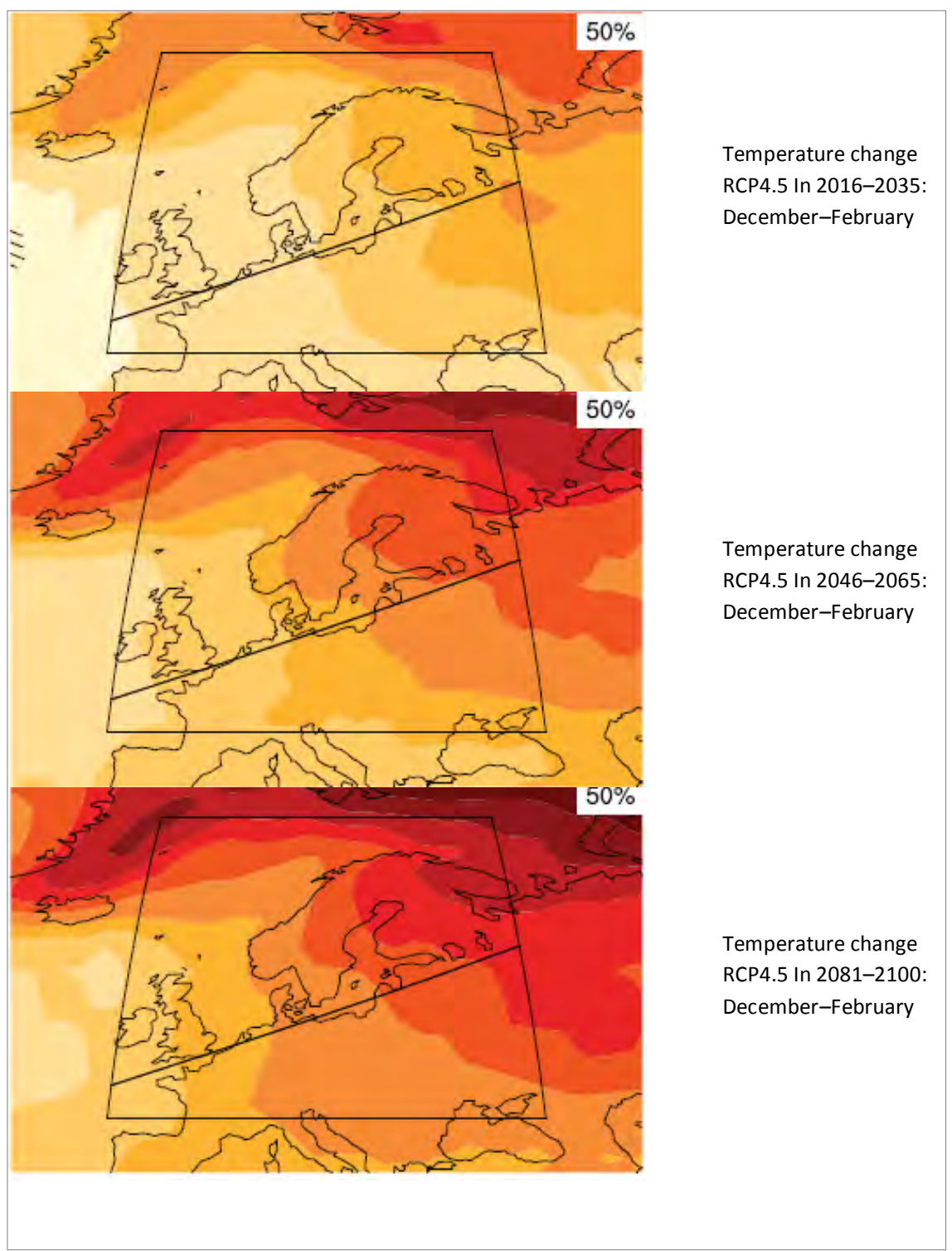

In winter (left) and summer (right) in Northern Europe according to RCP4.5. The time periods are 2016-2035 (upper), 2046-2065 (middle), and 2081-2100 (lower) relative to 1986-2005. 
Figure 2.4: The predicted precipitation changes

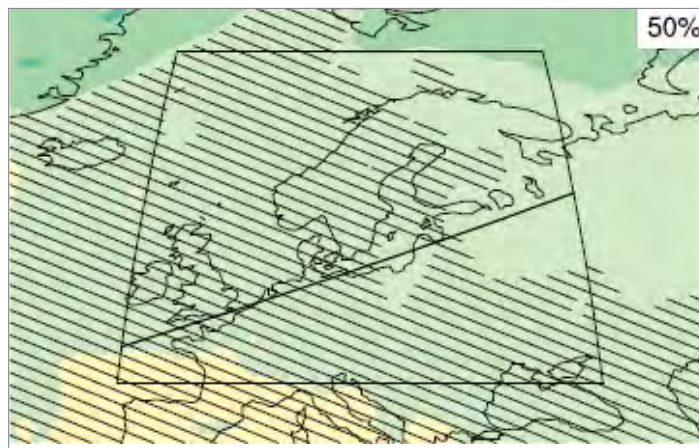

Precipitation change

RCP 4.5 In 2015-2035:

October-March

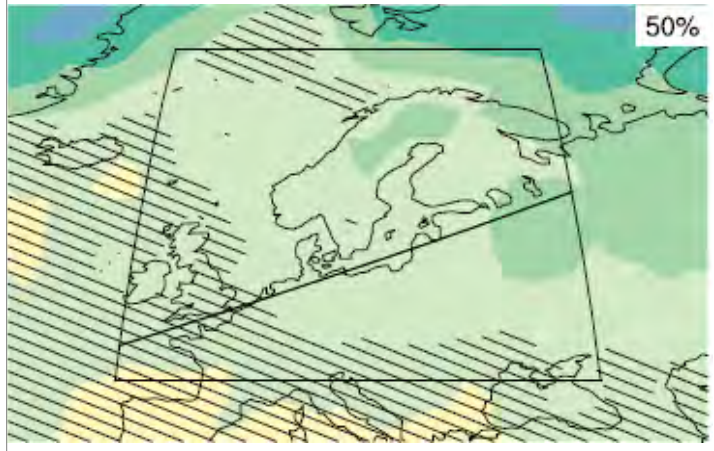

Precipitation change RCP 4.5 In 2046-2065:

October-March

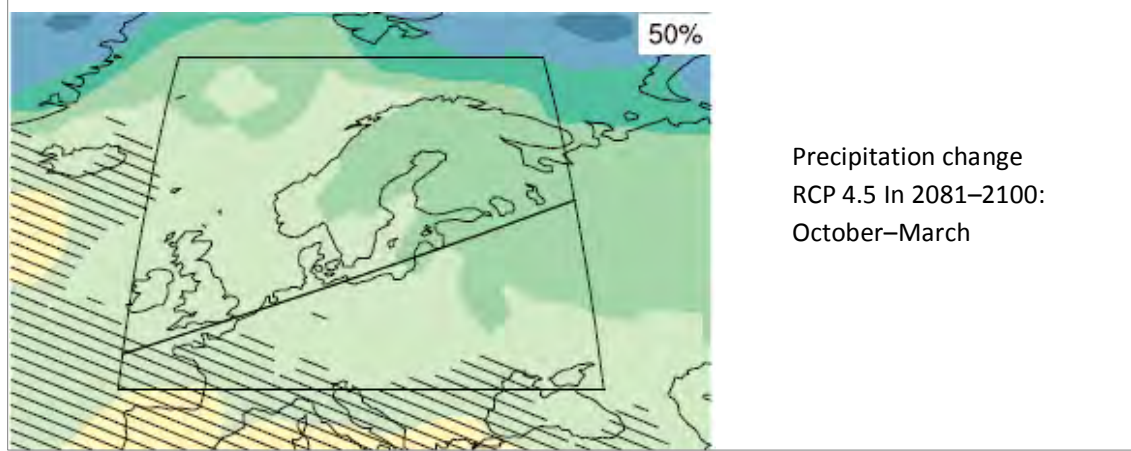

In winter (left) and summer (right) in Northern Europe according to RCP4.5. The time periods are 2016-2035 (upper), 2046-2065 (middle), and 2081-2100 (lower) relative to 1986-2005. Hatching denotes uncertainty in whether there will be an increase or decrease in precipitation.

\subsection{Conclusions}

This chapter has presented the climate of the Nordic countries, including past and future climate change. Natural variations play an important role in the Nordic climate, but the gradual warming caused by humanmade emissions is estimated to result in a significant rise in temperature in the 21st century. Climate change has been observed in the entire cli- 
mate system, with a global temperature increase of $0.89{ }^{\circ} \mathrm{C}$ since 1901 . According to the RCP4.5 pathway, the increase in global temperature by the end of the century will be $2.4^{\circ} \mathrm{C}$ relative to the pre-industrial level, compared to a $4.3{ }^{\circ} \mathrm{C}$ increase in a business-as-usual scenario. In the Nordic region, the temperature increase is estimated to be similar to the global mean in the south and west and near double in the north and east. The increase will be largest in winter and in regions with a continental climate. Precipitation is predicted to increase in most of the Nordic region, especially in winter. In the southern part of the Nordic region, especially Denmark, summer precipitation may decrease. More and heavier extreme precipitation events are expected. The change in wind conditions in the Nordic region is uncertain. The Atlantic Meridional Overturning Circulation (AMOC), which governs how much warm water is transported northwards with the Gulf Stream, will likely decrease by $20-30 \%$ by the end of the century according to the RCP4.5 pathway, but a collapse is very unlikely.

\subsection{References}

Bjørnæs, C. (2010): Klima forklart, Unipub.

IPCC (2000): Special Report on Emission Scenarios. Cambridge, United Kingdom, and New York, NY, USA, Cambridge University Press.

IPCC (2007): Climate Change 2007: The Physical Science Basis. Contribution of Working Group I to the Fourth Assessment Report of the Intergovernmental Panel on Climate Change. Cambridge, United Kingdom and New York, NY, USA, Cambridge University Press.

IPCC (2013): The Physical Science Basis. Contribution of Working Group I to the Fifth Assessment Report of the Intergovernmental Panel on Climate Change. Cambridge, United Kingdom and New York, NY, USA, Cambridge University Press.

Tveito, O. E., Førland, E., Heino, R., Hanssen-Bauer, I., Alexandersson, H. and coauthors (2000): Nordic temperature maps. Norwegian Meteorological Institute. 



\section{Emissions and carbon footprint}

\subsection{Introduction}

Over the period 1990-2011, GHG emissions in the Nordic countries decreased from 267 to 244 million tonnes of $\mathrm{CO}_{2}$ equivalents, excluding land use and land use change (LULUC) activities (see Figure 3.1). Including carbon sinks, the net emissions are significantly lower and the reduction over time larger (see Section 10.2).

The reduction was most significant in Denmark and Sweden, with an $18 \%$ and $16 \%$ reduction respectively, while emissions increased by $6 \%$ in Norway and $26 \%$ in Iceland. Reduced energy intensity is the main reason for the decreasing emissions. In Denmark, energy efficiency improvements over the past two decades mean that each unit of GDP required 30.7\% less energy in 2012 than in the 1990s (Danish Energy Agency 2014). In Norway, growth was largely the result of the petroleum sector, while the sharp rises in Iceland's emissions are due to the addition of new aluminium smelters (Norden 2014).

Most of the emissions stem from $\mathrm{CO}_{2}$, which comprised about $80 \%$ of total emissions (see Figure 3.2). The four largest countries each contribute $22-27 \%$ of Nordic emissions, while Iceland contributes only $2 \%$. 
Figure 3.1: GHG emissions in the Nordic countries, 1990-2011, in million tonnes $\mathrm{CO}_{2}$-equivalents

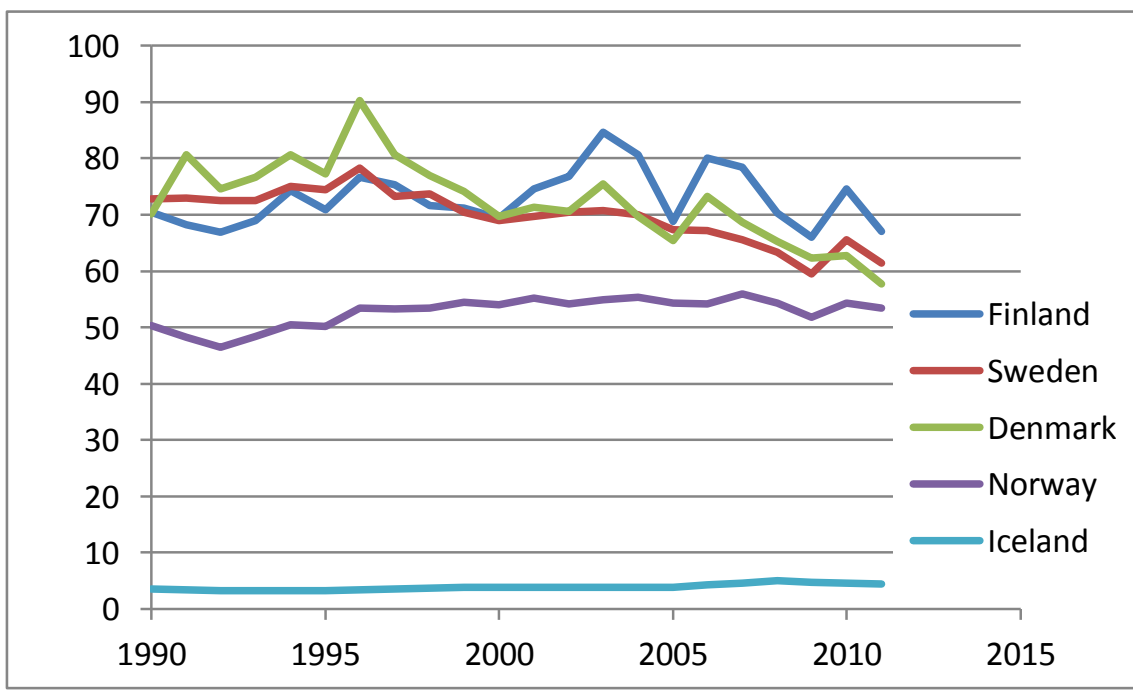

Source: OECD database.

Figure 3.2: Main GHG emissions in the Nordic countries in 2011, in million tonnes $\mathrm{CO}_{2}$-equivalents

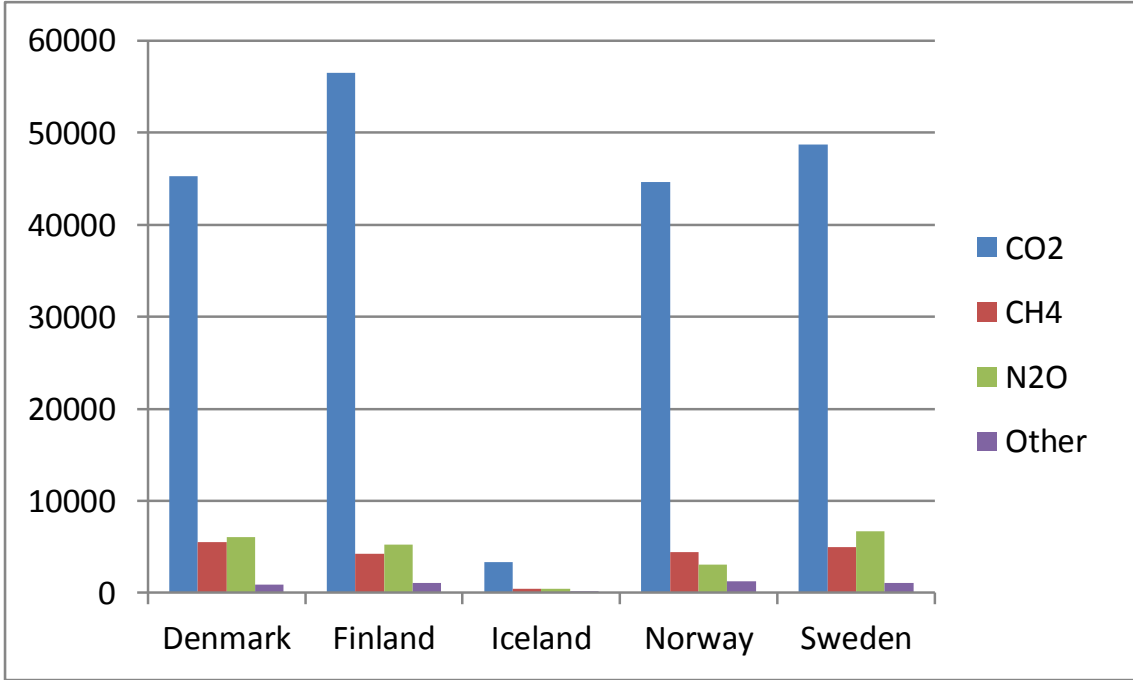

Source: OECD database.

Table 3.1 provides an overview of GHG emissions in the Nordic countries' primary sectors. The type of emission per sector is shown as a percentage of total GHG emissions in each country. The agriculture sector dominates emissions among the primary sectors in the Nordic countries, and globally the agricultural sector is the primary source of $\mathrm{CH}_{4}$ 
(methane) emissions. $\mathrm{CH}_{4}$ emissions stem from normal digestive processes in domestic livestock and from $\mathrm{CH}_{4}$ produced when manure is stored or managed in lagoons or holding tanks. Because humans raise these animals for food, the emissions are considered human-related. The contribution from the agriculture sector is particularly large in Denmark, where it accounts for $21 \%$ of GHG emissions.

\begin{tabular}{|c|c|c|c|c|c|}
\hline & $\begin{array}{r}\text { CO2 excl. } \\
\text { biomass }\end{array}$ & $\mathrm{CH} 4$ & N2O & Other & Total \\
\hline \multicolumn{6}{|l|}{ Denmark } \\
\hline Agriculture & 3 & 9 & 9 & & 21 \\
\hline Forestry & 0 & 0 & 0 & & 0 \\
\hline Fishing & 1 & 0 & 0 & & 1 \\
\hline \multicolumn{6}{|l|}{ Finland } \\
\hline Agriculture, fishing and aquaculture, hunting & 1 & 4 & 6 & & 11 \\
\hline Forestry & 0 & 0 & 0 & & 0 \\
\hline \multicolumn{6}{|l|}{ Iceland } \\
\hline Agriculture & & & & & 15 \\
\hline \multicolumn{6}{|l|}{ Norway } \\
\hline Agriculture & 1 & 0 & 3 & 4 & 8 \\
\hline Forestry & 0 & 0 & 0 & 0 & 0 \\
\hline Fishing & 2 & 0 & 0 & 0 & 2 \\
\hline \multicolumn{6}{|l|}{ Sweden } \\
\hline Agriculture & 2 & 0 & 0 & & 2 \\
\hline Forestry & 2 & 0 & 0 & & 2 \\
\hline Fishing & 0 & 0 & 0 & & 0 \\
\hline
\end{tabular}

Sources: databanks in OECD and national statistical bureaus; statbank.dk, stat.fi, statice.is, ssb.no, scb.se

\subsection{Carbon footprints of food}

Food production systems as a group are very diverse, the range of products is huge and production systems vary within product groups. Emissions of fossil $\mathrm{CO} 2$ from this group are less significant compared to N2O and $\mathrm{CH} 4$, the largest emissions of biogenic GHGs. These two GHGs are very potent, as $1 \mathrm{~kg}$ of $\mathrm{CH} 4$ is equivalent to $28 \mathrm{~kg}$ of $\mathrm{CO} 2$ while $1 \mathrm{~kg}$ of $\mathrm{N} 20$ is equivalent to $265 \mathrm{~kg}$ of $\mathrm{CO} 2$ (Myhre et al. 2013). The sum of GHGs, weighed and calculated into CO2-equivalents in a product's life cycle, is referred to as the product's carbon footprint (CF). Estimates of product CFs are used in analysis of mitigation options to ensure that suggested measures may actually result in an overall reduction of GHG emissions. Food product CFs are used commercially to inform consumers, e.g. a Swedish hamburger restaurant provides customers with in- 
formation on CFs for its different meals. In Sweden, national agencies have suggested climate taxes on food based on product CFs.

Large emissions of $\mathrm{CH} 4$ and $\mathrm{N} 2 \mathrm{O}$ from livestock production systems result in high carbon footprints of animal products. The Food and Agriculture Organization (FAO) estimates that world animal agriculture comprised 14.5\% of total GHG emissions in 2005 (Gerber et al. 2013). The livestock sector in the EU is estimated to have comprised $12.8 \%$ of total GHG emissions in 2004 (Leip et al. 2010)

Compared to animal products from agriculture, the correlation between energy use (and thus fossil $\mathrm{CO} 2$ emissions) and climate impact is often high for seafood products, especially for wild-caught fish. The climate impact of products from capture fisheries is dominated by fossil CO2 emissions from fuel use on fishing boats (Ziegler et al. 2012).

Global livestock production is a major driver of deforestation in South America as it has led to continued expansion of agricultural land for soybean cultivation (an important, high-protein ingredient for feed exported worldwide) and as pasture (for beef production). Due to lack of uniform methodology, GHG emissions from LULUC activities are seldom included in CF studies of agricultural products.

\subsubsection{Meat}

GHG emissions for production of meat worldwide have recently been reported by the FAO (Gerber et al. 2013) and the results from major production regions, including Europe, are shown in Figure 3.3. Methane from ruminants' enteric fermentation is generally the dominating source for beef CFs. However, for South American beef, land use change (LUC) emissions from expansion of pasture into natural forest ecosystems are also very important. Feed production is the largest emission source for pork and chicken, including LUC emissions from expanding soybean acreage for Western European and South American pork and chicken.

There is a large difference in carbon footprint between beef on the one hand and pork and chicken meat on the other, as illustrated in Figure 3.3, regardless of where in the world production takes place. Beef from South America has significantly higher CF than European beef due to high $\mathrm{CO} 2$ emissions from LUC as well as high $\mathrm{CH} 4$ emissions due to low animal productivity.

On average, European beef has the lowest carbon footprint in the world, due to its very high proportion (80\%) sourced from the dairy sector (slaughtered dairy cows, bull dairy calves) and generally high animal productivity (Gerber et al. 2013). The average CFs for beef in 
Figure 3.3 are in close agreement with studies by Cederberg et al. (2013) estimating GHG emissions from Swedish and Brazilian beef.

Figure 3.3: Life-cycle GHG emissions

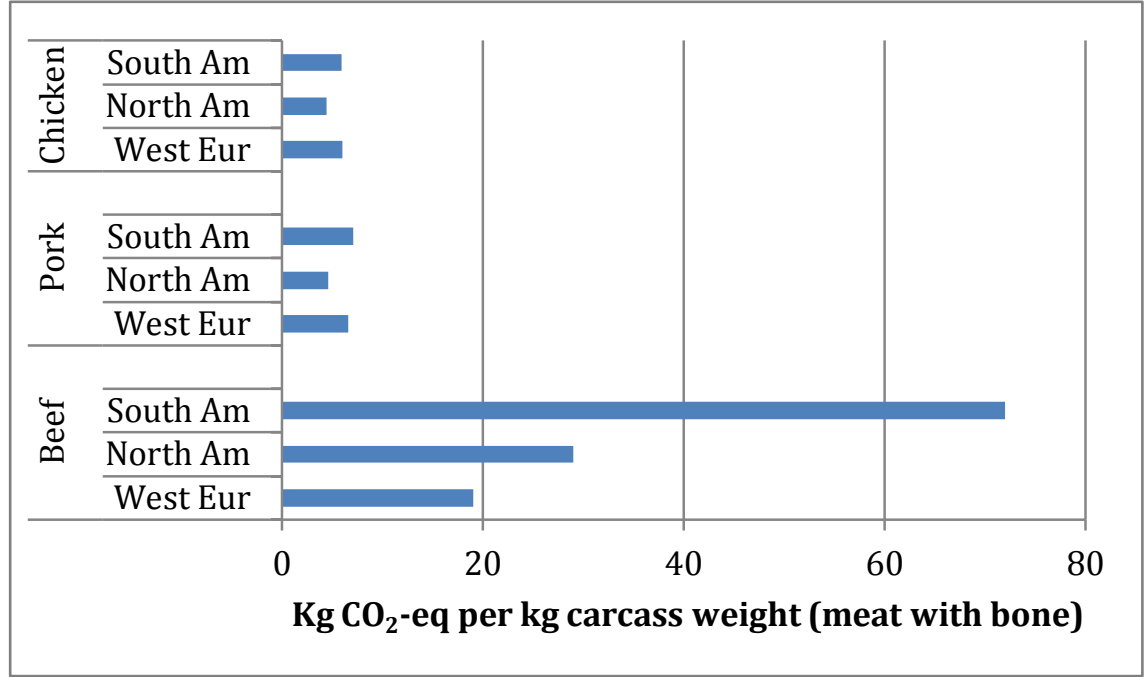

$\mathrm{Kg} \mathrm{CO} 2$-eq per kg meat with bone at retailer for beef, pork and chicken in the regions Western Europe, North America and South America (to be added: see Figures).

Source: Gerber et al. (2013).

The variation in CFs of pork and chicken meat from different regions in the world is smaller than for beef (Gerber et al. 2013). Dalgaard et al. (2012) report a significantly lower CF (3.5 kg CO2-eq per kg CW) for Danish pork than the European average, according to the recent FAO study (6.6 kg C02-eq per kg CW; see Figure 3.3), but the European average includes LUC emissions corresponding to $1.5 \mathrm{~kg}$ CO2-eq per kg CW. Adding this LUC estimate to Dalgaard's results yields a CF for Danish pork at roughly $5 \mathrm{~kg}$ CO2-eq per $\mathrm{kg}$ meat with bone, indicating a $\mathrm{CF}$ slightly below the European average.

\subsubsection{Dairy products and eggs}

As is the case with beef, $\mathrm{CH} 4$ from ruminants' enteric fermentation dominates the CF of milk, which varies in different regions of the world (see Figure 3.4). In egg production, feed production is the dominating source of GHG, as it is with chicken meat production.

Dairy production in Europe has the world's lowest GHG emissions, due to high animal productivity and high feed efficiency. Studies of GHG emissions from dairy farms in Norway, Sweden and Denmark point to a carbon 
footprint of milk at the farm-gate at roughly $1 \mathrm{~kg}$ CO2-eq per $\mathrm{kg}$ milk (Bonesmo et al. 2013, Cederberg et al. 2013, Kristensen et al. 2011), not including emissions from LUC. Adding these emissions (the FAO estimates close to $0.1 \mathrm{~kg} \mathrm{CO} 2$ per kg milk from LUC for European milk) as well as post-farm emissions suggests that milk production from Nordic countries lies in the lower range of European milk production and thus worldwide.

A lower CF for Swedish eggs (1.5 kg CO2-eq per kg at farm-gate) than the European average given by the FAO has been reported by Cederberg et al. (2013), but again not including emissions from LUC, which the FAO study estimates at $1.5 \mathrm{~kg} \mathrm{CO} 2$ per kg eggs as an average for European egg production. Adding these emissions and post-farm phase yields a slightly lower CF for Swedish eggs than the average European egg production.

Figure 3.4: Life-cycle GHG emissions

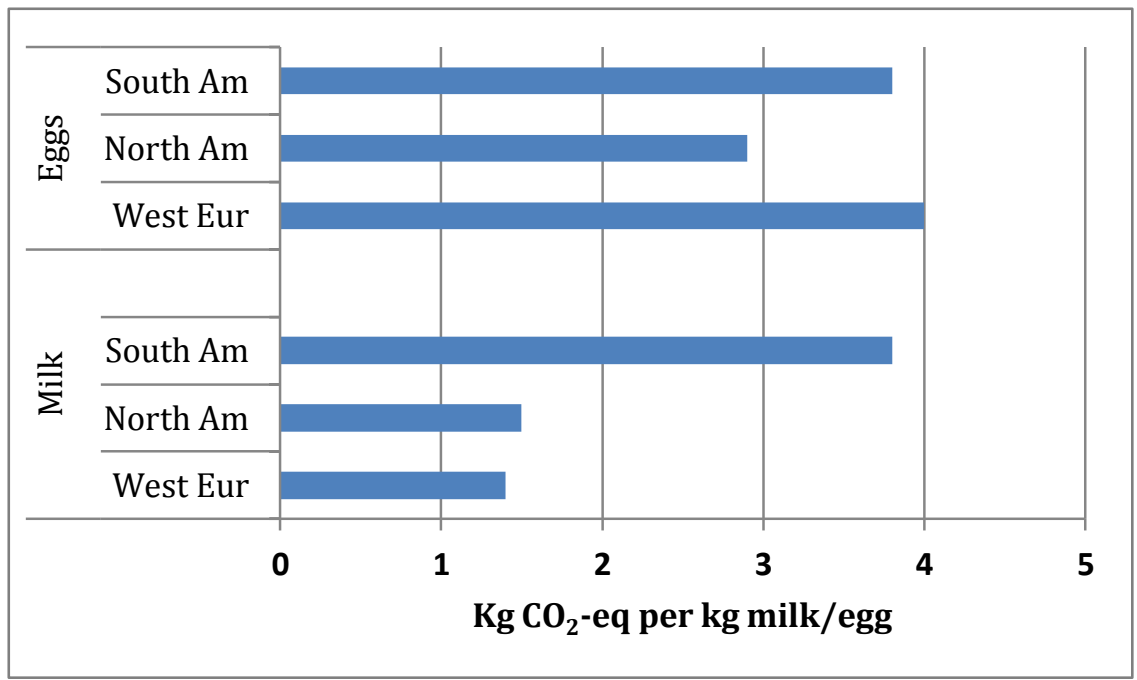

$\mathrm{Kg} \mathrm{CO}$-eq per kg at retailer for milk and eggs in the regions Western Europe, North America and South America (to be added: see Figures).

Source: Gerber et al. (2013).

\subsubsection{Vegetable products}

In general, vegetables are associated with fairly low GHG emissions and have generally lower life-cycle GHG emissions than animal products (examples of some vegetable products' CF are shown in Figure 3.5). Grain products, e.g. wheat flour, have a typical CF around $0.5 \mathrm{~kg} \mathrm{CO2-eq}$ per $\mathrm{kg}$, and use of primarily nitrogen fertilisers as well as diesel in the cultivation phase contributes to the dominating GHG emissions. Well- 
managed fertilisation and favourable yield levels are thus important for cereals' GHG emissions.

Potatoes and other root vegetables such as carrots are particularly efficient in cultivation, since the yield level is high per ha, resulting in low GHG emissions per kg product. However, depending on soil type the emissions can vary; cultivation in peat soils (which are quite common in some regions of the Nordic countries) leads to quite significant losses of $\mathrm{CO} 2$ and $\mathrm{N} 20$ from the soil and increase a product's final CF significantly.

GHG emissions from greenhouse products, such as tomatoes, are very sensitive to the source of heating of the greenhouse. Substituting fossil fuels with biofuels will thus have a significant impact on the product's CF. Generally, vegetables grown in open air have a lower CF than products grown in greenhouses using fossil fuels, but transport of such products can be of importance for vegetables imported to the Nordic countries. For example, for Spanish tomatoes imported to Sweden, transport emissions represent almost half of the tomatoes' $\mathrm{CF}$, resulting in a slightly higher CF than Swedish tomatoes cultivated in greenhouse with biofuels but significantly lower CF than tomatoes grown in greenhouse using fossil fuels (see Figure 3.5). Generally, life-cycle GHG emissions of vegetable foods are more sensitive to alternative energy use and efficiencies and transport modes in the supply chain than an animal food's CF since emissions of methane and nitrous oxide are so significant in milk and meat supply chains.

Figure 3.5: Life-cycle GHG emissions

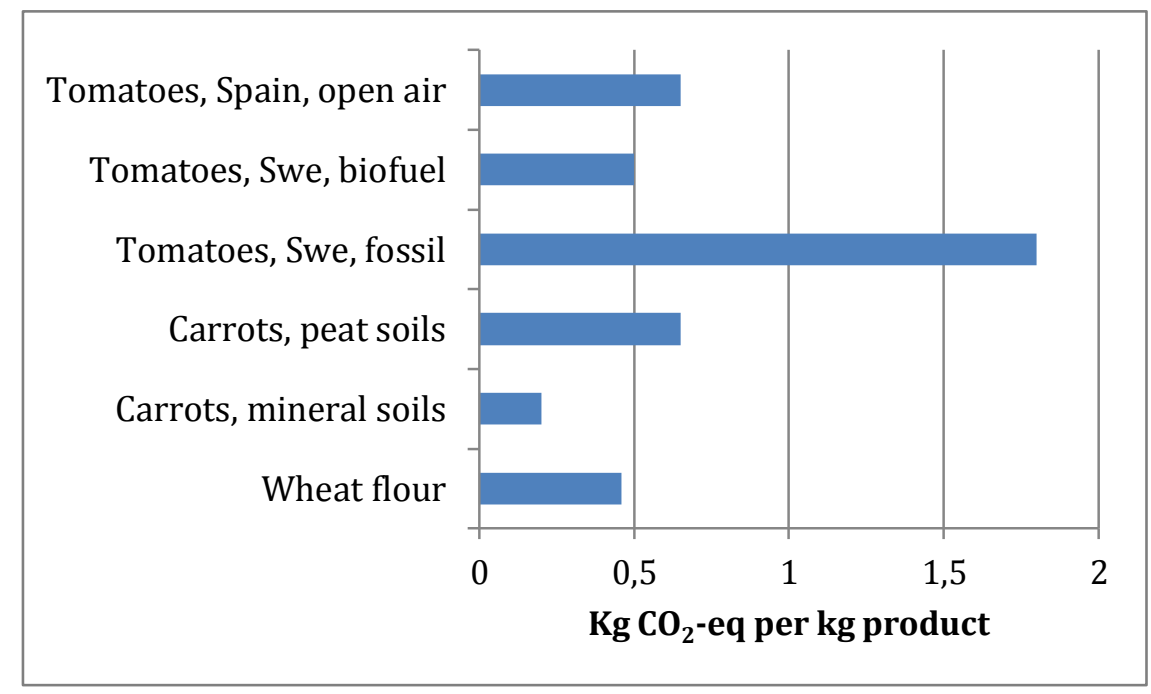

Kg CO2-eq per kg for some vegetable products at retailer in Sweden.

Source: Sonesson et al. (2010). 


\subsubsection{Aquaculture}

GHG emissions from Norwegian farmed salmon are estimated at around $2 \mathrm{~kg}$ CO2-eq per kg live weight fish; depending on processes and transports, the final consumer products end up in the range of $2.5-3.6 \mathrm{~kg}$ CO2-eq per kg edible product at wholesalers in Northern Europe (see Figure 3.6). Norwegian salmon has a lower CF than farmed salmon in Canada, Chile and the UK, which is a result of high feed efficiency and lower use of farm-level energy in the Norwegian production (Pelletier et al. 2009). Average feed consumption is estimated at $1.2 \mathrm{~kg}$ dry feed per $\mathrm{kg}$ live weight salm-on in Norway and $60 \%$ of the feed is of marine origin (fish meal, fish oil) while $40 \%$ is from agricultural production (most importantly soymeal, rapeseed oil and wheat) (Winter et al. 2009).

Mussels feed on planktonic organisms filtered through water flowing through the farm site and relatively small volumes are produced. The GHG emissions come from maintenance and harvest boats using diesel for the production of blue mussels and are in the same range per $\mathrm{kg}$ of edible product as fresh salmon (Ziegler et al. 2012).

\subsubsection{Captured fish}

Besides emissions from fossil fuels, leakage of refrigerants from the cooling system in fishing vessels contributes to the overall carbon footprint for seafood from capture fisheries. As seen in Figure 3.6, herring and mackerel have the lowest climate impact; the fishing methods used to harvest pelagic fish such as these species include purse seining and pelagic trawling, which are among the most energy-efficient fishing methods. Bottom trawlers, frequently used for cod and haddock, require considerably more fuel per kg landed fish (Zigler et al. 2012, Winter et al. 2009).

There are strong indications that overfishing leads to increased fuel use and thereby a higher CF of fish products (Schau et al. 2009). The CFs of captured fish reported in the Norwegian study are low in an international perspective, due to relatively low fuel use in the demersal fishery and relatively well-managed fish stocks (Winter et al. 2009). CFs of 6.1 $\mathrm{kg}$ CO2-eq and $4.8 \mathrm{~kg} \mathrm{CO2}$-eq per $\mathrm{kg}$ edible cod are reported for the western Baltic and the eastern Baltic cod stock respectively. These numbers are higher than the Norwegian results shown in Figure 3.6, and they reveal a significant difference in CF between cod from different stocks. The west-ern Baltic stock is more intensively fished than the eastern stock and there is a strong correlation between fuel consumption and level of fishing for cod in the Baltic (Emanuelsson 2012). 
Figure 3.6: Life-cycle GHG emissions

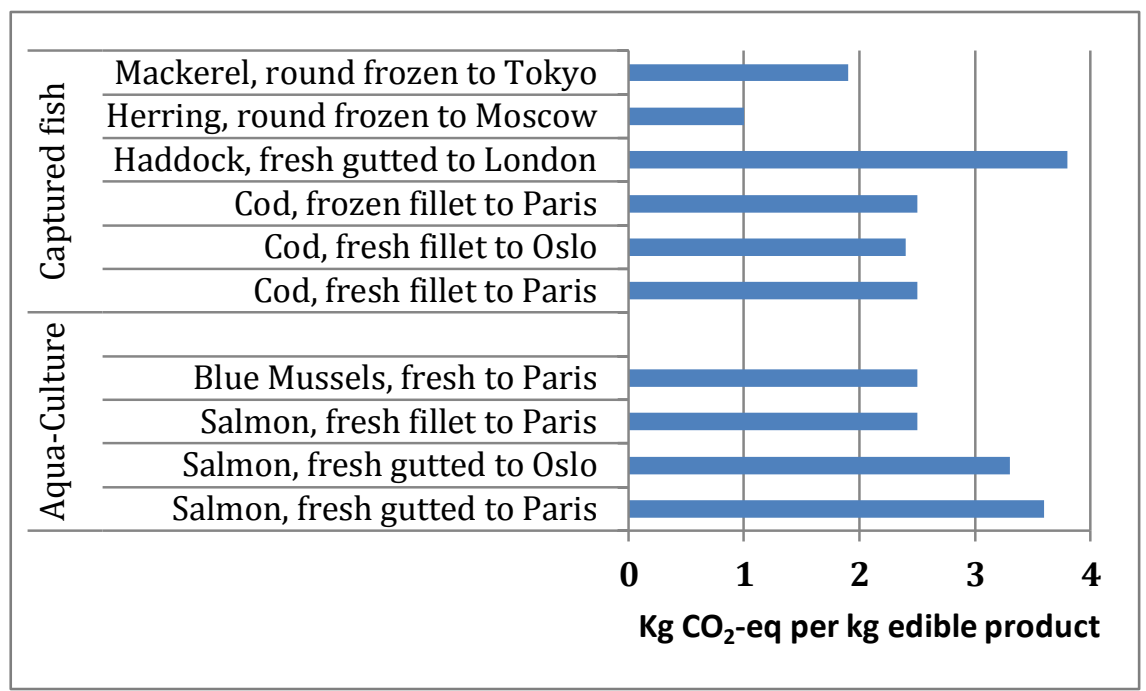

$\mathrm{Kg} \mathrm{CO} 2$-eq per kg edible product for Norwegian seafood at wholesaler.

Source: Winther et al. (2009), Ziegler et al. (2012).

\subsubsection{Reducing the impact from food chains}

Despite the large uncertainties associated with estimates of biogenic GHG emissions (N2O, CH4 and non-fossil CO2), there is well-supported, con-sistent information from the many LCA/CF studies published so far on how to reduce the climate impact from food production. Deforestation associated with expanding agricultural land into pristine ecosystems needs to be slowed and stopped since it is associated with large GHG emissions and also considerable biodiversity losses. Nitrogen manage-ment needs to be improved in order to significantly reduce reactive $\mathrm{N}$ emissions and input of synthetic fertilisers that result in not only GHG emissions but also eutrophication problems. Use and dependency of fossil fuels in cultivation, fishing, processing and transport need to be reduced in order to cut $\mathrm{CO} 2$ emissions and the extraction of fossil resources. 


\subsection{Mitigation}

\subsubsection{General policy}

Cost efficiency and the polluter-pays principle are key criteria in Nordic climate policy, and taxes on greenhouse gases and the tradable allowances are the main instruments. Carbon taxes have existed internationally for over 20 years, with Finland as the first nation to adopt a carbon tax in 1990. Subsequently, Norway (1991), Sweden (1991), Denmark (1992) and Iceland (2010) implemented carbon taxes. No country applies a costefficient, flat, uniform tax rate as recommended by economic theory. Instead, the taxes vary highly among countries and between sources within each country. Primary industries are normally exempt from taxation. Industries are sheltered from carbon taxes or are allowed to pay lower tax rates; gasoline, coal and natural gas face the highest taxes.

All the Nordic countries participate in the EU emission trading system EU ETS. A cap is set on the total amount of certain GHGs that can be emitted by the installations in the system. The cap is reduced over time so that total emissions fall. In 2020, emissions from sectors covered by the system will be $21 \%$ lower than in 2005 . Within the cap, companies receive or buy emission allowances which they can trade with one another as needed. The flexibility inherent in this trading ensures that emissions are cut where it costs least to do so.

The primary industries are not included in the ETS nor are they subject to carbon taxes. Still, the sectors are indirectly influenced by these instruments. For example, the primary industries use production equipment manufactured by industries facing higher energy costs from the regulations. In addition, many sources for biofuels are also sources for feedstuffs for livestock, and thus biofuel production increases the prices of livestock feeds. Thus, the industries indirectly meet incentives to substitute carbonintensive inputs. Also, the energy prices increase due to the ETS, and carbon taxes stimulate lower energy use and transition to energy-efficient equipment in primary industries. Such indirect effects are difficult to isolate from other factors influencing the industries, but the incentives are clearly towards lower emission impact. In future policy formulation, GHG emissions may be covered by economic incentives. A growing number of emission trading schemes and initiatives around the world allow emission reductions from forestry to be traded (Portin et al. 2013). Any changes to include such sector enlargements, and the inclusion of new GHGs such as methane from agriculture, would be after the third phase of the EU ETS (2013-2020) (Portin et al. 2013). 


\subsubsection{Sector-specific policies}

Forestry has potentially the most influential impact on GHG emissions (see Section 2.2). Norway aims to decrease deforestation, and increase reforestation and forest density by fertilisation (Ministry of Environment 2012). In contradiction of this policy, biofuels from forest harvests are frequently suggested alternatives to fossil fuels. However, the recent literature increasingly points out the net effect of accounting carbon storage in forests. A high level of harvest implies that the carbon stock in the forest stabilises at a lower level. Therefore, wood harvesting is not a carbon-neutral activity (Holtsmark 2012). The climate impact of biofuels vs. forest growth is hence presently an ongoing debate in climate policy formulation.

In 2010, agriculture contributed $10 \%$ of Norwegian emissions. Instruments to reduce these emissions include development of biogas collection from manure and waste.

Apart from efforts to increase forest growth and utilise biogas, direct instruments to reduce GHGs in the primary industries are rather weak. Table 3.2 summarises the environmental policy instruments in the agricultural sector. According to Prestvik et al. (2013), Denmark, Sweden and Norway focus on GHG emissions among several issues, while Finland mainly focuses on nutrient leakage and Iceland on soil conservation.

\begin{tabular}{|c|c|c|}
\hline Country & $\begin{array}{l}\text { Environmental } \\
\text { concern }\end{array}$ & Main type of agri-environmental subsidies \\
\hline $\begin{array}{l}\text { Denmark. } \\
\text { Rural development } \\
\text { programme } \\
2007-2013\end{array}$ & $\begin{array}{l}\text { Rich nature and } \\
\text { clean environ- } \\
\text { ment }\end{array}$ & $\begin{array}{l}\text { Extensive farming } \\
\text { Biogas } \\
\text { Set-aside buffer zones } \\
\text { Energy crops } \\
\text { Maintaining wetlands } \\
\text { Rare livestock breeds } \\
\text { Municipal wetland projects } \\
\text { Environment conditional grants } \\
\text { Environmentally friendly technologies } \\
\text { Nature and environment projects } \\
\text { Natura } 2000 \text { projects } \\
\text { Conversion to organic farming } \\
\text { Management of EB-grassland } \\
\text { Management of pasture and natural areas } \\
\text { Organic fruit trees and berry production } \\
\text { Island support }\end{array}$ \\
\hline
\end{tabular}




\begin{tabular}{|c|c|c|}
\hline Country & $\begin{array}{l}\text { Environmental } \\
\text { concern }\end{array}$ & Main type of agri-environmental subsidies \\
\hline $\begin{array}{l}\text { Sweden. } \\
\text { Rural development } \\
\text { programme } \\
2007-2013\end{array}$ & $\begin{array}{l}\text { Sustainable } \\
\text { development in } \\
\text { agriculture }\end{array}$ & $\begin{array}{l}\text { Environmental compensation for: } \\
\text { Pastures and hayfields } \\
\text { Forage cultivation } \\
\text { Certified organic or recycling-oriented production } \\
\text { Natural and cultural environments in the agricultural landscape } \\
\text { Reduced nitrate leaching } \\
\text { Brown beans on Öland } \\
\text { Endangered livestock breeds } \\
\text { Buffer zones } \\
\text { Environmental precautions } \\
\text { Natural promotion efforts on farmland } \\
\text { Compensation within designated environments (pastures and } \\
\text { hay meadows, arable land, water, cultural heritage) }\end{array}$ \\
\hline Norway & $\begin{array}{l}\text { Sustainable } \\
\text { agriculture }\end{array}$ & $\begin{array}{l}\text { Acreage and cultural landscape payments } \\
\text { Payments for animals on pasture } \\
\text { Support for preserving rare livestock breeds } \\
\text { Support for organic farming } \\
\text { Regional environmental programmes (cultural landscapes, } \\
\text { cultural heritage, biodiversity, recreational values, runoff to } \\
\text { water, reduced use of pesticides) } \\
\text { Payments for environmentally friendly spreading of manure } \\
\text { Special environmental measures in agriculture (cultural land- } \\
\text { scape, pollution and facilitation) } \\
\text { Selected cultural landscapes }\end{array}$ \\
\hline $\begin{array}{l}\text { Finland. } \\
\text { Rural development } \\
\text { programme } \\
2007-2013\end{array}$ & $\begin{array}{l}\text { Reduce nutrient } \\
\text { loadings from } \\
\text { agricultural lands } \\
\text { to water }\end{array}$ & $\begin{array}{l}\text { Basic measures: monitoring and planning of farm practices, } \\
\text { fertilisation of arable land, and headlands and filter strips } \\
\text { Additional measures: reduced fertiliser use, more accurate } \\
\text { nitrogen fertilisation, plant cover in winter, reduced tillage, } \\
\text { extensive grassland production, spreading of manure in } \\
\text { growing season, calculation of nutrient balances, cultivation of } \\
\text { catch crops. } \\
\text { Special measures: Establishment and management of riparian } \\
\text { buffer zone, management of multifunctional wetlands, arable } \\
\text { farming in groundwater areas, more efficient reduction of } \\
\text { nutrient loadings, runoff water treatment methods, and } \\
\text { incorporation of liquid manure in the soil }\end{array}$ \\
\hline Iceland & Soil conservation & $\begin{array}{l}\text { Payments that aim to enhance sustainable land use and } \\
\text { restoration of degraded land }\end{array}$ \\
\hline
\end{tabular}

Source: Prestvik et al. (2013).

\subsection{References}

Bonesmo, H., Beauchemin, K.A., Harstaad, O.M. and Skjelvåg, A.O., 2013. Greenhouse gas emission intensities of grass based silage dairy and beef production: A system analysis of Norweigan farms. Livestock Science, 152(2-3), 239-252.

Cederberg, C., Hedenus, F., Wirsenius, S. and Sonesson, U., 2013. Trends in greenhouse gas emissions from consumption and production of animal products in Sweden - implications for a long-term climate target. Animal, 7(2), 330-340.

Dalgaard, R., 2007. The environmental impact of pork production from a life cycle perspective. Ph.D. Faculty of Agricultural Sciences, University of Aarhus.

Danish Energy Agency, 2014. Energy statistics 2012. 
Emanuelsson, A., 2012. Quantifying Overfishing and Ecosystem Impacts Related to Seafood Products. Licentiate. Department of Biological and Environmental Sciences, University of Gothenburg.

Gerber, P.J., Steinfeld, H., Henderson, B., Mottet, A., Opio, C., Dijkman, J., Falcucci, A. and Tempio, G., 2013. Tackling climate change through livestock - A global assessment of emissions and mitigation opportunities. Rome: Food and Agricultural Organization of the United Nations (FAO).

Holtsmark, B., 2012. Harvesting in boreal forests and the biofuel carbon debt, Climatic Change, 112(2), 415-428.

Kristensen, T., Mogensen, L., Knudsen, M.T. and Hermansen, J.E., 2011. Effect of production system and farming strategy on greenhouse gas emissions from commercial dairy farms in a life cycle approach. Livestock Science, 140(1-3), 136-148.

Leip, A. et al., 2010. Evaluation of the livestock sector's contribution to EU greenhouse gas emissions (GGELS) - final report. European Commission, Joint Research Centre.

Meld. St. 21 (2011-2012) Norwegian Climate Policy, white paper from the Ministry of the Environment.

Myhre, G. et al., 2013. Anthropogenic and Natural Radiative Forcing. In: Stocker, T.F.D. et al., eds. Climate Change 2013: The Physical Science Basis. Contribution to Working Group I to the Fifth Assessment Report on the Intergovernmental Panel on Climate Change. Cambridge, UK, and New York, NY, USA: Cambridge University Press.

Norden, 2014. The Nordic way: Visualising energy in the Nordic region. Available at: http://www.nordicenergy.org/thenordicway/country/iceland/

Pelletier, N., Tyedmers, P.H., Sonesson, U., Scholz, A., Ziegler, F., Flysjö, A., Kruse, S., Cancino, B. and Silverman, S., 2009. Not all salmon are created equal: Life cycle assessment (LCA) of global salmon farming systems. Environmental Science and Technology, 43(23), 8730-8736.

Portin, A., Barua, S., Clarke, M., Camargo, M., Viding, J. and Pekkanen, M., 2013. The Role of Forests in Climate Change: Nordic Experience. TemaNord 2013:559.

Prestvik, A.S., Kvakkestad, V. and Skutevik, Ø., 2013. Agriculture and the environment in the Nordic countries: Policies for sustainability and green growth. TemaNord 2013:558.

Schau, E.M., Ellingsen, H., Endal, A. and Aanondsen, S.A., 2009. Energy consumption in Norwegian fisheries. Journal of Cleaner Production, 17(3), 325-334.

Sonesson, U., Davis, J. and Ziegler, F., 2010. Food production and emissions of greenhouse gases. Report 802. Gothenburg: Swedish Institute for Food and Biotechnology (SIK).

Winther, U., Ziegler, F., Skontorp Hognes, E., Emanuelsson, A., Sund, V. and Ellingsen, H., 2009. Carbon footprint and energy use of Norwegian seafood products. SFH80 A09 - Open Report. Trondheim, Norway: SINTEF Fisheries and Aquaculture.

Ziegler, F., Winther, U., Skontorp Hognes, E., Emanuelsson, A., Sund, V. and Ellingsen, H., 2012. The Carbon Footprint of Norwegian Seafood Products on the Global Seafood Market. Journal of Industrial Ecology, 17(1), 103-116. 



\section{Fisheries}

\subsection{Introduction}

This chapter focuses upon the roles of climate variability and climate change on fish and fisheries within the Nordic region. First there is a brief discussion of ocean climate variability and climate change, accompanied by a description of some of the large-scale climate indices and their connection to regional marine climate variability. The effects of climate forcing on marine and freshwater ecosystems are then described, with an emphasis on fish populations, and several examples of observed responses of these ecosystems to past and recent climate changes are presented. Also presented are likely future scenarios of fish and fisheries under expected anthropogenic climate change. Based on these results, the fisheries and ecosystem management issues and how they might change under a future climate are discussed. The potential economic and social implications of climate change for the coastal communities and the Nordic nations are also considered. A summary includes a number of identified knowledge gaps that need to be filled.

\subsection{Projections of future ocean climate variations}

The IPCC reports $(2007,2013)$ conclude that anthropogenic-induced global warming is well under way. As discussed in Chapter 1, annual air temperatures in Europe will rise, with the largest increases relative to recent conditions in the north. The ocean, because of its higher capacity to store heat, will not warm quite as much as the land. Thus, ocean temperatures are projected to rise by $1-3{ }^{\circ} \mathrm{C}$ in the Nordic Seas through the 21st century (Melsom et al. 2010, IPCC 2013). As with the atmosphere, the frequency of extreme high-ocean and freshwater temperatures will increase and extreme low temperatures will decrease (IPCC 2013).

As temperatures rise, sea-ice coverage in the north will decrease (Figure 4.1) with the possibility of a summer ice-free Arctic by 2050 or earlier (Stroeve et al. 2007). In the Barents Sea, the winter ice edge is projected to retreat at an approximate rate of $10 \mathrm{~km}$ per year northward and there will be a significant loss of ice cover in the western Nordic 
Seas, which by 2070 will be restricted to the northwestern Greenland Sea (Furevik et al. 2002). Increased ice melt, precipitation and river runoff in northern latitudes will lead to decreases in surface salinity of the order 0.5 to 1 in the western regions of the Nordic Seas (Furevik et al. 2002). In the eastern sections and the Barents Sea, salinities may increase (Bethke et al. 2006) as Atlantic waters spread farther east and north. These Atlantic waters are expected to be higher in salinity than at present because of increased evaporation in their source region of the tropics. Continental runoff will increase in the Nordic regions, which will more than compensate for the influx of high-salinity Atlantic water. Near-surface stratification is expected to increase in the Norwegian Sea and perhaps elsewhere in the Nordic Seas due to heating and added fresh water but this is highly uncertain and will depend upon the change in winds and extent of wind mixing. In freshwater systems, ice will form later on the lakes and in rivers in the autumn or winter and will clear earlier in the spring.

Figure 4.1: The winter

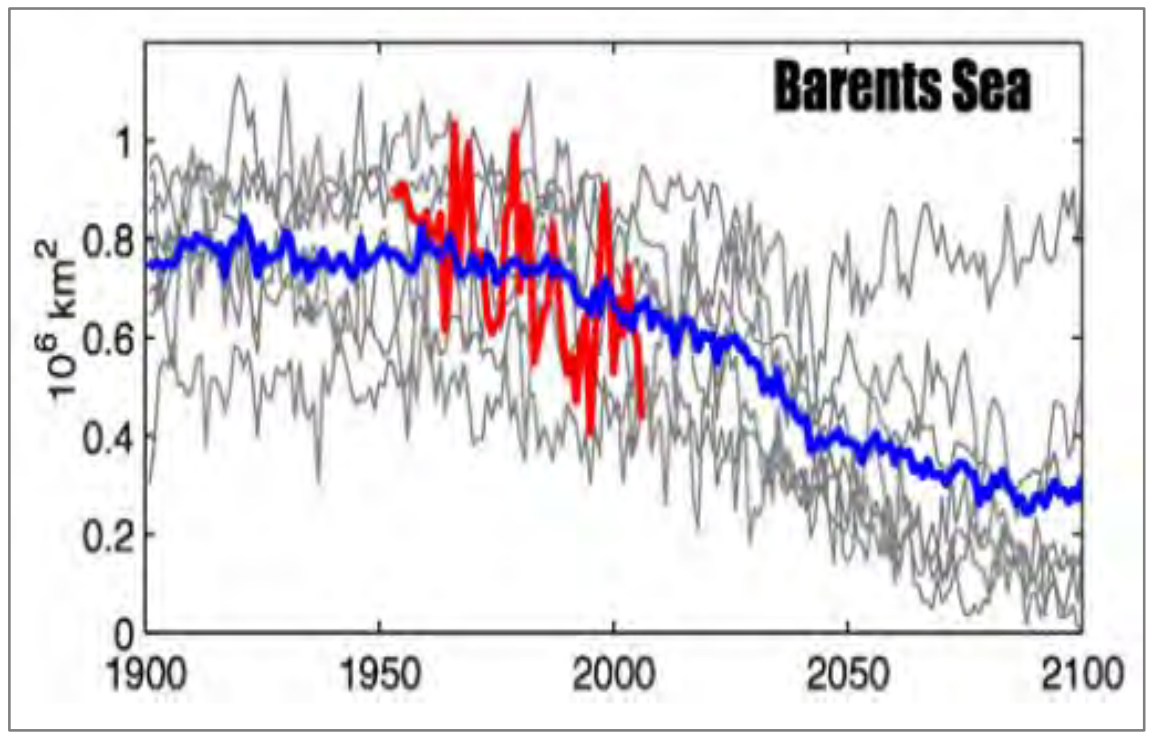

(March and April average) sea ice area for the Barents Sea (1900-2100) based on different model results (grey lines). The blue line represents the ensemble mean and the red line the observed.

Source: Overland and Wang (2007).

The position of the Arctic and Polar fronts in the Nordic Seas that separate the warmer, saltier Atlantic-derived waters from the colder, lowersalinity Arctic waters are generally not expected to change greatly as they are strongly controlled by bottom topography. However, the Polar 
Front in the Barents Sea will, on average, likely be slightly farther north and east than at present (Huse and Ellingsen 2008) or may even move to the continental slope of the Barents Sea adjacent to the Arctic Ocean (Wassmann et al., submitted). If this occurs, the entire Barents Sea would become much warmer and saltier.

During the 21st century there is expected to be a gradual weakening by about $20-30 \%$ in the Meridional Overturning Circulation (MOC) (IPCC 2013). The MOC involves the northward flow near surface of warm water from the south, cooling and sinking in the northern North Atlantic including in the Nordic Seas, and the subsequent flow back south in subsurface layers. The density-driven component of this flow is referred to as the thermohaline circulation and together with wind forcing makes up the MOC. Most modelling studies suggest that in spite of its expected weakening, the current warming trend is likely to continue with increases of $2^{\circ} \mathrm{C}$ or more over this century. However, the model by Keenlyside et al. (2008) predicts that the weakening of the MOC over the next decade will result in a cooling effect on climate around the North Atlantic. Such a cooling could temporarily offset the longer-term warming trend from increasing levels of GHGs in the atmosphere (Wood 2008).

In addition to the increasing upward trend of sea surface temperatures, there is high variability at a multitude of time scales. The annual to decadal temperature variations are of large amplitude with smaller amplitude fluctuations at multidecadal scales (Figure 4.2). The impact of these changes on the marine ecosystems differs. As the time scale of the physical forcing increases, there is a tendency for the nature of ecological changes to progress from local effects on individuals at synoptic weather scales, towards regional effects on population dynamics at monthly to decadal scales, and over basins and even across basins on ecological systems at multidecadal time scales and longer (Stenevik and Sundby 2007). For example, the annual to decadal temperature variations may have an impact on production on lower trophic levels as well as fish recruitment and year-class strength, while multidecadal variations will have greater impact through habitat expansion and production, especially on higher trophic levels such as fish. It is important to take these different frequencies into consideration when discussing future development in the Nordic ecosystems. 
Figure 4.2: The 0-200 m depth averaged current from the Kola section in the Barents

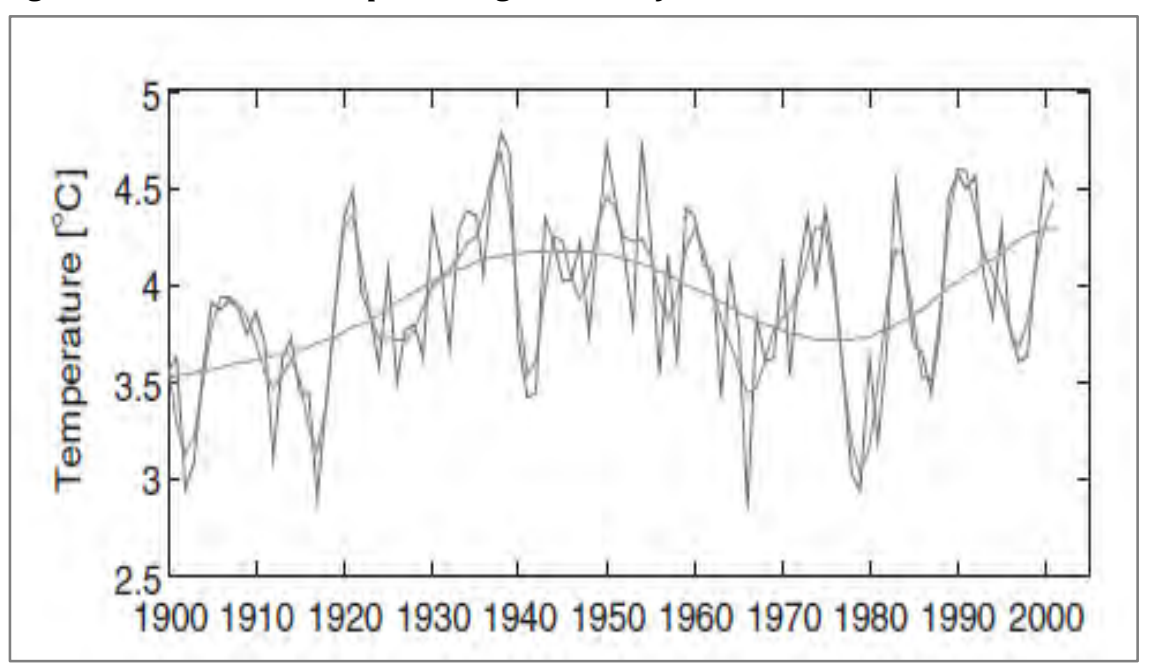

Sea showing annual means (blue), 3-year running means (red) and the 60-year trend (green)

Source: Stenevik and Sundby (2007).

\subsection{Fish and fisheries responses to past and recent climate variability}

Climate variability has historically led to significant fluctuations in fish and fishery yields in the Nordic regions. These climate effects can be direct, such as through inducing physiological changes, or indirect through, for example, effects on predators or prey.

\subsubsection{Marine species}

Given that marine fish production ultimately depends upon plankton and benthic production (in the case of demersal fish species), it is useful to begin this section by documenting some of their changes induced by climate.

\section{Plankton and benthos}

Plankton production depends upon available nutrients, sufficient light levels, and strong enough vertical stratification of the water column to keep the plankton near the surface where light levels are high. If mixing is too strong the plankton can be mixed below depths with sufficient light and production will be limited (Sverdrup 1953). If the stratification is too strong it prevents nutrients from being mixed from the subsurface depths into the upper layers. Vertical stratification of the water column is largely determined by the opposing forces of mixing (most often by 
the wind), solar heating and freshwater supply, with their relative importance depending upon location (Olsen et al. 2003, Rey 2004). In regions with sea ice, the ice decreases phytoplankton production by limiting light levels (Rey and Loeng 1985). Primary production in the Barents Sea can be as much as $400 \%$ higher in a warm year with reduced ice compared to a cold year with increased ice coverage (Slagstad and Wassmann 1997). In the recent warm years with reduced ice, primary production in the Barents Sea has increased because of higher light levels and a longer production period (Mueter et al. 2009).

Zooplankton form the link between primary producers and planktivorous fish. Their abundance depends upon phytoplankton production as well as the ocean climate. Sea temperatures affect their survival rate by influencing the duration of their various life stages. A $0.5^{\circ} \mathrm{C}$ rise in temperature has been suggested to increase the survival of the subarctic copepod Calanus finmarchicus, the dominant zooplankton species throughout the northern North Atlantic including the Nordic Seas, by 30\% (Tittensor et al. 2003). The circulation can also affect zooplankton. In the mid-1990s a weakening of the anticlockwise circulation in the northern North Atlantic, known as the subpolar gyre, resulted in decreased abundances of $C$. finmarchicus that inhabit the gyre (Hátún et al. 2009). This weakening also allowed more subtropical waters and its associated zooplankton fauna to flow into the Nordic Seas as well as south of Iceland (Hátún et al. 2009). C. finmarchicus also overwinters in the Iceland Basin (Heath et al. 2000) and changes in their biomass are known to vary with the amount of subarctic water in the basin.

Benthic populations (those living on or near bottom) also respond to long-term variations in marine climate. Benthic production depends upon the amount of primary production that sinks to the ocean floor. Benthic species are temperature-dependent and are therefore influenced by changes in near-bottom temperatures. For example, during the extended warm period that began in the 1920s and extended into the 1950s, Arctic benthic species retreated along the Murman coast in the Barents Sea, while the number of boreal species increased as the influence of Atlantic waters increased. The relative number of Atlantic species doubled between the period prior to and during the peak of the warming (Nesis 1960). In the Norwegian Sea west of Spitsbergen, Atlantic benthic species on the shelf spread northward approximately $500 \mathrm{~km}$ between studies before and after the warming (Blacker 1957, 1965). Similar northward movement is occurring during the present warming period. An example is the blue mussel (Mytilus edulis) that was discovered in northern Spitsbergen after an absence of almost 1000 years. Its presence is attributed to 
warming caused by the increased transport of Atlantic waters into the near-shore regions of Spitsbergen (Berge et al. 2005).

\section{Fish}

Climate plays an important role in producing changes in the distribution and production of the major fish species. The world's largest Atlantic cod (Gadus morhua) population, the Northeast Arctic stock, spawns off the coast of Norway and drifts as larvae northward, eventually entering the Barents Sea, where it spends its entire adult life. Good recruitment of cod is dependent on higher than average temperatures (Sætersdal and Loeng 1987, Ottersen and Sundby 1995). This is caused by (i) higher primary production (Svendsen et al. 2007), (ii) a larger influx of zooplankton into the Barents Sea (Skjodal and Rey 1989, Sundby 2000) and (iii) higher temperatures promoting higher biological activity at all trophic levels (Sakshaug 1997).

Distributional shifts also accompany temperature changes, e.g. young cod in the Barents Sea are distributed more southwestward during cold conditions and northeastward during warm periods (Midttun et al. 1981). Cod moved north during the warm periods of the 1930s and 1940s. During cooler periods in the 1960s, cod retreated farther south, especially off West Spitsbergen (Blacker 1957). During the recent warming period, cod in the Barents Sea set a new northward record during the late summer, reaching above $80^{\circ} \mathrm{N}$ in 2012 (see Figure 4.3). Also, during warm years, more cod spawn in northern regions of Norway relative to cold periods (see Figure 4.4).

Figure 4.3: The abundance of cod during the fall surveys showing the distribution during (A) 2004 and (B) 2012. Note the high abundances to the north during 2012 that set new historic high-latitude records for cod in the Barents Sea

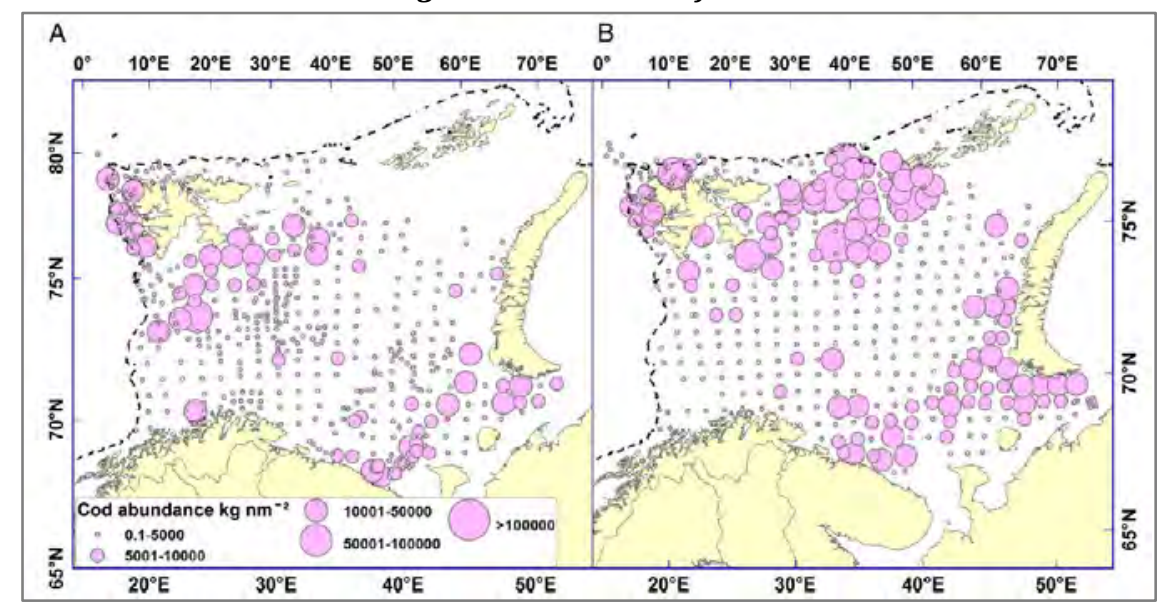

Source: Kjesbu et al. (2014). 
Figure 4.4: The spawning sites (green areas) of the Northeast Arctic cod stock off the coast of Norway. During warm periods there is increased spawning northwards (red arrow) and in cold periods there is more spawning to the south (blue arrow)

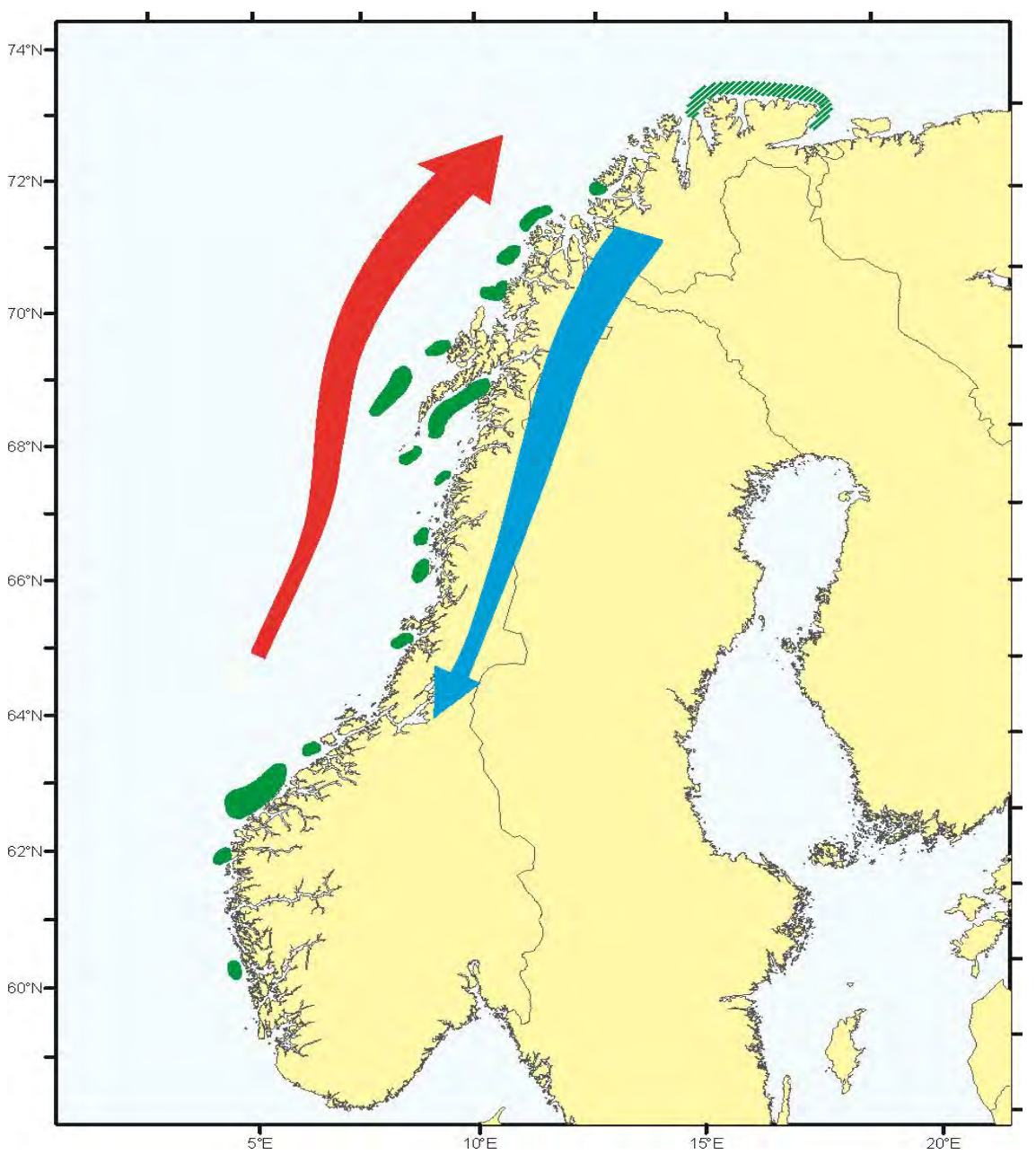

Source: Sundby and Nakken (2008).

Norwegian spring-spawning herring (Clupea harengus) spawn along the coast of Norway and drift as larvae and young juveniles into the southern Barents Sea, where they spend the first 1-3 years of life. During the warm 1930s, they expanded their distribution eastward in such numbers that a herring fishery developed along the Murman coast where previously this species was almost unknown (Beverton and Lee 1965). By age 2-3, the herring leave the Barents Sea and move into the Norwegian Sea. As adults, they spawn along the coasts of Norway in spring, and during the late spring and summer head into the Norwegian Sea to feed. 
The abundance of herring has tended to increase in parallel with the temperature increases, as observed in the 1930s and the 1990s (see Figure 4.5). During warm periods the adults move farther westward in the Norwegian Sea and into Icelandic waters (Vilhjálmsson 1997). During the warm 1930s, a large Icelandic herring fishery developed and prospered until the stock collapsed in the late 1960s owing to poor environmental conditions and heavy fishing pressure. A fishing moratorium was imposed for almost 20 years and the herring did not recover until temperatures improved, with abundance increasing in parallel with the rise in temperature (Toresen and Østvedt 2000).

Figure 4.5: The smoothed time series of the spawning stock biomass of herring in the Norwegian Sea (red line) and the Kola section temperatures (blue)

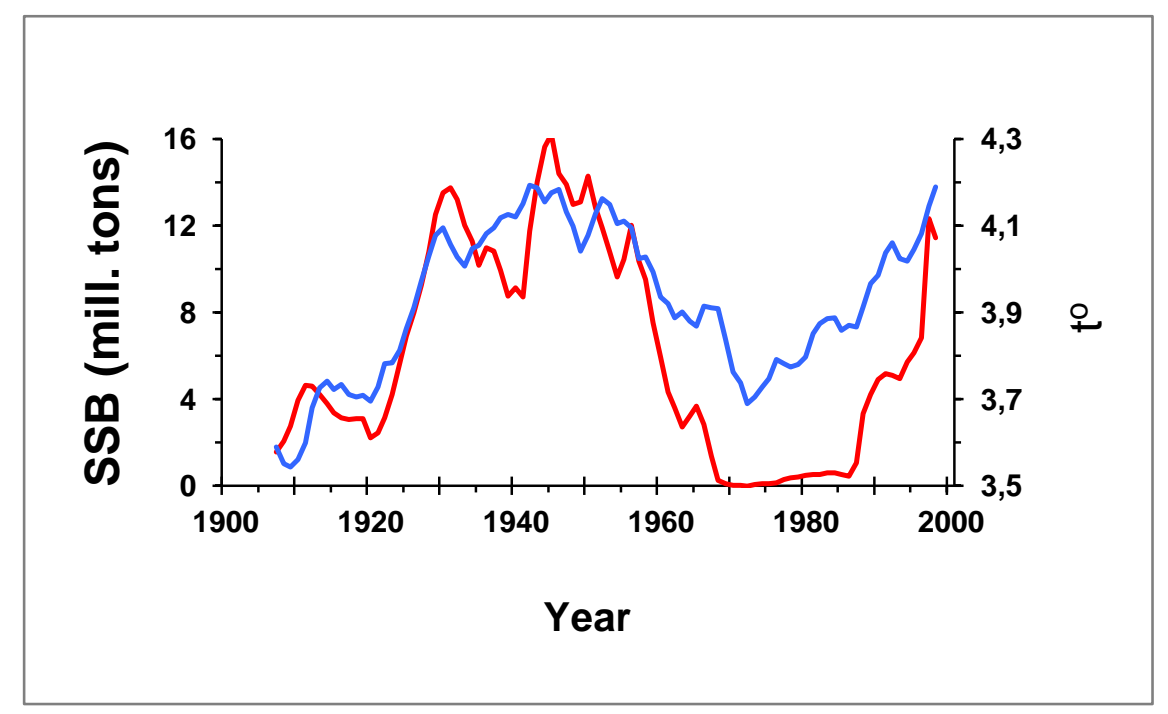

Source: Toresen and $\emptyset$ stvedt (2000).

Changes in climate also affect predator-prey interactions. In the Barents Sea an increase in the basic metabolic rate of Atlantic cod, associated with higher temperature, results in an increase in consumption of capelin by 100,000 tonnes per degree centigrade (Bogstad and Gjøsæter 1994). While the capelin can move farther north and eastwards so as to partly escape cod predation, moving into these colder waters causes slower growth and later maturity, thus leading to a smaller spawning stock biomass of capelin and ultimately a weak year-class. This is a prime example of how species interactions can change under different climate regimes. This is further highlighted by the fact that different species will tend to move northward at different rates, thereby changing 
the overlap between predators, prey and competitors (Mueter and Litzow 2008). This will lead to new interactions between species.

\subsubsection{Freshwater and anadromous species}

The freshwater fish fauna of Northern Europe is highly influenced by glaciation history (Griffiths 2006). Northern Europe was repeatedly glaciated by ice sheets during the Pleistocene epoch (Ice Age), which began around 1.8 million years ago and ended about 10,000 years ago. The current native fish fauna is therefore composed of species that could expand into the area following the retreat of the last ice sheet, through rivers, ice lakes or from the ocean. Due to various reasons, not all species from the nonglaciated parts of Europe managed to colonise the formerly glaciated region. As a consequence, the freshwater fish fauna of Northern Europe is less diverse than in Central and Southern Europe and is largely characterised by habitat generalists that tend to be migratory (Griffiths 2006, Reyjol et al. 2007). Although species richness is less in the formerly glaciated regions, sympatric ecomorphs of some species such as Arctic char (Salvelinus alpinus) and European whitefish (Coregonus lavaretus) (Østbye et al. 2005) are relatively common, putatively reflecting early stages of speciation. Such ecomorphs are virtually nonexistent in southern species (Bernatchez and Wilson 1998), which are more specialised (Griffiths 2006). The relatively recent colonisation of Northern Europe is also reflected in the makeup of the species, as genetic variation and population differentiation are less than in the non-glaciated parts of Europe (Bernatchez and Wilson 1998). After the last retreat of ice sheets and later, some populations became landlocked as the route from sea or other watersheds became impassable for fish. Also, the cold-water species Arctic char retreated in Southern Europe but is still found in mountain lakes and rivers such as in the Alps (Brunner et al. 1998).

The most economically valuable freshwater species in the Nordic countries are the salmonids Atlantic salmon (Salmo salar), brown trout (Salmo trutta) and Arctic char. All of these species have anadromous populations that go to sea for feeding (Klemetsen et al. 2003). The temperature preferences of these species differ. Atlantic salmon prefer the warmest and the most nutrient-rich rivers and Arctic char the coldest and most unproductive watersheds. Brown trout prefer intermediate temperatures and nutrient concentrations compared to the other two species (Elliott and Elliott 2010, Jonsson and Jonsson 2009).

Salmonid species are plastic generalist species which form distinct genetic populations among rivers (or among tributaries within large 
river systems) and lakes. Salmonid populations are adapted to their local environments, including temperature regimes or temperaturecorrelated environmental factors (Fraser et al. 2 2011, Vincent et al. 2013). Temperature can have direct effects on physiology and lifehistory traits, as well as indirect effects, such as influencing food availability, competition, predation, spread of pathogens and water quality (Jonsson and Jonsson 2009). Distribution and population trends of different fish species have changed because of recent climate changes (Comte et al. 2013). For example, the observed declines in population size of Atlantic salmon stock complexes in Europe and North America in recent decades have been associated with the AMO index (see above) and warming ocean surface temperature, causing ecological regime shifts (Friedland et al. 2013). In fresh water, recent changes in thermal freshwater habitats have also affected population size and distribution of several salmonid species, e.g. negatively affecting brown trout in the Mediterranean region and in the Alps (Comte et al. 2013 and references therein). In Iceland and Norway, many anadromous Arctic char populations have been declining (Svenning et al. 2012, Guðbergsson 2013). In Great Britain, southern non-migratory fish species displayed a mean of $47 \mathrm{~km}$ northward shift of range margin during the last quarter of the 20th century (Hickling et al. 2006). Although it is clear that recent climate changes have affected abundance and distribution of fish species and populations, the overall impact is unknown.

\subsection{Fish and fisheries responses to future climate change}

\subsubsection{Marine species}

\section{Plankton and benthos}

Rising temperatures in the Norwegian Sea will increase vertical stratification of the water column, which in turn will reduce the amount of nutrients reaching the upper surface layers. Thus, primary production is expected to decrease over much of the North Atlantic, including the Nordic Seas, except where sea ice will be reduced or disappear (Kristiansen et al. 2014). Enhanced annual primary production will occur in these latter regions because of increased light levels and an extended growing season. In regions where the seabed or the depth of mixing is $<40 \mathrm{~m}$, diatom blooms would be favoured. If mixing is extended to about $80 \mathrm{~m}$ it would likely favour Phaeocystis, and if the surface mixed layer extended 
beyond about $80 \mathrm{~m}$, it is possible that a low-productive community dominated by nanoflagellates would be favoured (Loeng et al. 2005). The latter would imply little transfer of carbon to herbivores and the sediments because the grazers would be largely ciliates (Sakshaug and Walsh 2000). Reductions in sea ice will also result in the loss of iceassociated algae, which makes up around $10 \%$ of the total production in the Barents Sea and other areas near the southern limit of the ice but up to $50 \%$ in the high Arctic.

Expected earlier phytoplankton blooms under a warming scenario could result in a mismatch with zooplankton and thus potentially less zooplankton prey for fish larvae and young juveniles (Hansen et al. 1996). The reduced grazing on phytoplankton could increase the sinking flux of particulate matter from the sea ice to the sediments (Arrigo et al. 2008). However, if advection of increasingly warm surface waters is responsible for the early losses of sea ice, zooplankton growth may not be negatively affected and carbon export may remain unchanged or even diminish. Furthermore, reduced sea-ice cover has been proposed to favour a pelagic-dominated ecosystem over the more typical sea-ice algae to benthos ecosystem (Piepenburg 2005). Such an ecosystem switch would reduce the vertical export of organic carbon and decrease pelagicbenthic coupling. Thus what will happen in regards to pelagic-benthic coupling remains unclear.

The abundance of zooplankton in the Nordic Seas (principally C. finmarchicus) greatly depends on phytoplankton production and growth rate. The latter will increase due to rising temperatures but as indicated above, model studies indicate that phytoplankton production may decrease over much of the Nordic Seas, except in regions with reduced sea ice, where it will likely increase (Krisitiansen et al. 2014). Increases in Atlantic zooplankton abundance are expected in the eastern and northern regions of the Barents Sea, while the biomass of larger Arctic species will decrease, leading to an overall decrease in zooplankton (Ellingsen et al. 2008). However, this does not take into account possible changes in predation of zooplankton by higher trophic levels, although it is well known that zooplankton abundance varies with the population size of capelin (Gjøsæter et al. 2002, 2009).

\section{Fish}

Early studies of fish production in the Nordic and Barents Seas suggested that production will increase under climate change, as was the case during past warm periods, owing to anticipated higher phytoplankton production because of the loss of seasonal sea ice (Svendsen et al. 2007). For example, cod recruitment in the northern areas would increase and 
coupled with higher temperature-dependent growth rates would result in an increase in total cod biomass, which in turn could lead to increased fish catches there (Drinkwater 2005, Stenevik and Sundby 2007, Filin and Oganin 2008). Salmon abundance in Russian waters has also been projected to increase, as previously observed under warm conditions (Lajus et al. 2005). However, more recent modelling studies suggest that at least cod recruitment throughout the North Atlantic, including the Northeast Arctic cod stock, is likely to decline (Kristiansen et al. 2014). This is due to modelled declines in the zooplankton in the region of spawning as a result of lower nutrient concentrations in the surface layers from reduced phytoplankton production through increased stratification. While there are some data to suggest that zooplankton did increase during the earlier warm periods (Colebrook 1978, Drinkwater 2006), the abundance of zooplankton under increasing warming and stratification may indeed decline. However, this is still a scientifically debated topic and not yet fully resolved.

A northward expansion of fish has been suggested under climate change (Stenevik and Sundby 2007, Cheung et al. 2008), including more spawning in northern regions and less in the south (Sundby and Nakken 2008, Huse and Ellingsen 2008). In the Barents Sea, distributional shifts of fish such as cod, haddock (Melanogrammus aeglefinus) and herring towards the east and north would result in a higher proportion of the population moving into Russian waters (Loeng et al. 2005). If substantial numbers of Atlantic mackerel (Scomber scombrus) expanded northward and into the Barents Sea, they could act to reduce the cod population through predation on their larvae and young juveniles. Whether the cod population in the Barents Sea ultimately increases or decreases thus depends on several factors and the balance between recruitment, growth and predation, all of which are still highly uncertain. Also, new species entering the Barents Sea will compete for food with the existing species. Cheung et al. (2009) suggested that the Nordic and Barents Seas would be expected to see a relatively large number of invasive species, local extinctions and hence species turnover related to distributional shifts. Species whose northward extension could have important ecosystem consequences are blue whiting (Micromesistius poutassou) and Atlantic mackerel through competition for food with the existing species. One population that has been estimated to disappear from the Nordic and Barents Seas within approximately 30 years is polar cod, Boreogadus saida (Cheung et al. 2008). It should be noted that the ultimate fate of many of the fish species, even under climate change, will also depend upon the fisheries and thus fisheries management. 
Vikebø et al. (2007) examined the potential impact of a reduction in the large-scale thermohaline circulation (THC) in the North Atlantic on the drift and hence growth and distribution of larvae and juveniles of the Northeast Arctic cod. The THC brings warm water north which cools, sinks and returns as a deep water current. The authors imposed a threetimes-present river discharge to the Nordic Seas and the Arctic Ocean, which reduces the strength of the THC by $35 \%$. This is near the projected reduction of around $25 \%$ in the THC predicted by the end of the $21 \mathrm{st}$ century in the IPCC report (2007). Vikebø et al. (2007) found that this reduction results in fewer juvenile cod transported eastwards in the Barents Sea, and those that were transported were considerably smaller in body size because of cooler temperatures. More juvenile cod were transported to the western parts of Spitsbergen, where feeding conditions are poorer and survival rate is lower than in the Barents Sea, which led to an overall increase in cod mortality for the year class. Some juveniles would possibly reach into the Arctic Ocean but were not expected to survive.

\section{Marine mammals and seabirds}

Seals, such as the ringed seals that breed and raise their young on or near the ice edge, would experience a loss of habitat under climate change. If this resulted in a significant decrease in their abundance levels, it would lead to reduced predation on fish species such as polar cod, capelin and Atlantic cod. Durner et al. (2009) suggested that within the Arctic, the greatest rate of loss of polar bear habitat over the 21st Century would occur in the Barents Sea with a rate of $6.5 \%$ per decade. Polar bears, which hunt seals near the ice edge, would have to move farther north in search of prey. The earlier spring ice break-up and later fall freeze-up would force the polar bears either to leave the ice earlier in the spring or to deal with an unstable ice edge, leading to a general reduction in body condition. Female bears would have to go longer distances in pursuit of food, leaving cubs unattended and vulnerable (Stirling et al. 1999). Walruses and whales, which rely on sea ice of a relative thickness that they can break through to create breathing holes, would benefit from a thinner ice sheet, but walruses would then encounter the problem of finding adequate sea ice to support their weight during their resting periods.

Seabirds are also susceptible to climate change. Changing fish distributions may require seabirds to alter their foraging range in an attempt to locate suitable prey or adapt to a different food source. This could result in recruitment failure. Generally, seabirds feed only within $100 \mathrm{~km}$ of their breeding sites but this range may have to be extended 
under climate change. In the Barents Sea, future projections have suggested that there will be a shift away from the plankton feeding seabirds, such as puffins, towards species that feed on small forage fish (FalkPetersen et al. 2007).

\subsubsection{Freshwater and anadromous species}

Climate change is predicted to affect the distribution and abundance of many freshwater and anadromous fish species. Freshwater systems in Northern Europe will be subjected to higher temperatures, altered precipitation patterns and likely more frequent extreme weather events (see above). The projected effects of climate change on fish are species/population-specific and will range from positive to negative. The effects may depend on factors such as physiological thermal preference and tolerance, availability of thermal refugia, migration possibilities, prey availability, inter- and intraspecific competition, predation, impact of diseases and pathogens, phenotypic responses (plasticity) and the ability to adapt to changing environmental conditions (e.g. Jonsson and Jonsson 2009, Moss et al. 2009, Comte et al. 2013). Higher temperatures may increase overall productivity in fresh water, which may increase fish production but may also decrease it if lakes become eutrophic and oxygen-depleted. Many rivers and lakes may become too warm for salmonid and coregonid species, which could be replaced by cyprinid species (Moss et al. 2009). Other weather extremes, such as floods and droughts, can decrease recruitment and survival of fish (Jonsson and Jonsson 2009). Possible displacement of salmonid and coregonid species with more warm-adapted species would likely have major negative consequences for recreational fisheries (Moss et al. 2009).

Simulation studies have been used to predict the effects of climate change on culturally and economically important fish species, such as Atlantic salmon and Arctic char. For example, Hedger et al. (2013) predicted that Atlantic salmon abundance might increase in northern and western Norway but decrease in southern Norway. Overall, higher temperatures were predicted to induce faster growth of juveniles, earlier smolting and elevated smolt production, which eventually might result in increased egg deposition and elevated recruitment. However, low summer water levels in southern Norwegian rivers were predicted to increase density-dependent mortality of parr (Hedger et al. 2013). Compared to other salmonids, Arctic char is most sensitive to warm water and is expected to suffer in large regions from rising temperatures (Reist et al. 2006). In the study by Hein et al. (2012), it was predicted that Arctic char 
might lose $73 \%$ of its range in Sweden by 2100 , whereas its distribution might become limited to large lakes and mountainous regions. The distribution shrank not only because of increased temperatures but also because of the projected invasion of the top predator pike (Esox lucius) (Hein et al. 2012). Similarly, although brown trout is expected to outcompete Arctic char in lakes becoming warmer and more productive (Finstad et al. 2011), expansion of pike might eliminate brown trout from thousands of lakes in Sweden (Hein et al. 2014), as well as species such as crucian carp (Carassius carassius) and stickleback (Pungitius pungitius).

\subsection{Socio-economic and institutional issues}

\subsubsection{Institutional issues: spatial and substantive coverage of existing international arrangements and decision-making}

The potential effects of climate change are under discussion in all economic sectors, including living marine resources. Several international institutions related to fisheries have voiced their concern in this regard, such as the FAO Committee of Fisheries (COFI) ${ }^{1}$ and the UN General Assembly in its 2007 fisheries resolution. ${ }^{2}$ The implications of climate change for fisheries is not an area where it is easy to provide definite answers (Browman 2008).

As discussed earlier, changes in the geographic distribution of various fish species are expected under climate change (see also ACIA 2005). It is now recognised that this is an extremely complex issue. Fish have always moved and changes in migratory ranges are nothing new. But what is new, in a historical perspective, is the establishment since the 1970s of boundaries in the oceans out to 200 nautical miles, defining who owns what and who decides what can be fished and where. While a fishing vessel 40 years ago could follow the fish, today it cannot necessarily do so if the fish enter the waters of another country or the high seas where quotas are set by regional fisheries management organisa-

\footnotetext{
${ }^{1}$ Climate Change and Fisheries and Aquaculture. COFI/2009/8, FAO, Rome.

2 Resolution adopted by the General Assembly 62/177. Sustainable fisheries, including through the 1995 Agreement for the Implementation of the Provisions of the United Nations Convention on the Law of the Sea of 10 December 1982 relating to the Conservation and Management of Straddling Fish Stocks and Highly Migratory Fish Stocks, and related instruments. A/RES/62/177.
} 
tions or arrangements. A permit to fish in such waters would be needed. Historically, this is an entirely new situation where the effects of climate change raise new issues.

Previous studies have shown that management measures turned out to have a greater impact on the economic performance of fisheries than assumed changes caused by climate change (e.g. Eide 2008). However, these studies did not take into account the possibility of spatial shifts, which may be the most important factor in terms of climate change impacts. Four major issues arise in this context:

1. Bioeconomic theory and issues involving spatial distribution, including how spatial models could be set up for fisheries targeting sedentary species.

2. Other achievements in bioeconomic research, including different types of theoretical developments in resource economics with relevance in the discussion of climate change impacts.

3. Management issues related to spatial distribution when discussing fisheries agreements under exogenous change in conditions on which the Baltic Sea cod fishery is based, as well as the impact that subsidies may have on the exploited ecosystems.

4. Modelling spatial distribution, which has been addressed by ideas from inter alia bioeconomic modelling.

\subsubsection{Socioeconomic issues: harvesting strategies, spatial distribution, and energy consumption}

Climate variability in the oceans is nothing new. The fluctuations in fish landings observed in the past have been associated with fluctuations in the underlying fish stocks caused by environmental fluctuations (see above). In some cases fish stock collapses have been caused by failed or absent management, but usually in combination with declining environmental conditions (Lilly et al. 2013). For example, the collapse of the northern cod of Newfoundland was caused by a management failure, but much helped by a cooling of ocean temperature that decreased productivity and increased the availability of fish in areas where the water was still relatively warm. The obvious lesson to draw from these stories, and many others untold here, is that climate variability in the oceans is an important factor to take into account in managing fisheries. This poses difficult questions about the meaning attached to the concept of sustainability.

Changes in ocean climate produce two major kinds of changes in fish stocks and fisheries. First, they affect stock productivity, negatively or 
positively. Secondly, shifts in stock distribution may occur and migration patterns may be altered. Changes in fish stock productivity will obviously have important economic implications. Reductions in productivity will reduce the total fish catch, leading to loss of markets and redundancies of labour and capital equipment in the fishing industry. Positive changes in productivity are easier to live with, but will necessitate expansion of markets and investment in equipment in the fishing industry to take advantage of new opportunities. Changes in location and migrations of fish stocks may also strain existing agreements on fish stock sharing or necessitate entirely new ones. Both types of change can lead to a fish stock moving partly or wholly out of the economic zone of Country A and into the zone of Country $B$, or change the extent to which the stock is located in the two countries' respective zones. A number of such changes have occurred in the recent past, such as with Atlantic mackerel (Hannesson 2013).

With regard to climate change and its effects on fisheries, the research has mainly been focused on changes in distribution of fish stocks that straddle the boundaries between different jurisdictions (Miller and Munro 2004, Hannesson 2007a, b, Miller 2007, Ekerhovd 2010). However, Brandt and Kronbak (2010) evaluated the possibilities of achieving a cooperative agreement for a jointly exploited resource if the resource itself is subject to an exogenous change. Applying this to Baltic cod they show that if climate change increases the biomass of the stock, then there is an increased possibility of achieving a cooperative agreement (Brandt and Kronbak 2010). In reality, Russia and Norway share the total allowable catch (TAC) of the Northeast Arctic cod equally. (In addition, the treaty between Norway and Russia also includes haddock and capelin and allows for some minor share to be fished by third-country vessels).

The global emissions reduction regime, as laid down in the 1997 Kyoto Protocol, requires developed countries to cut their emissions to an average of $5.2 \%$ of 1990 levels by 2008-12. This is a tall order and is not likely to be achieved. In a longer-term perspective (2050), emissions have to be reduced to $50 \%$ or less of 1990 levels in order to avoid $\mathrm{CO}_{2}$ concentrations in the atmosphere and therefore temperature increases that are incompatible with the maintenance of the current state of the natural environment.

Climate mitigation in the context of fisheries is about reduction of emissions from fishing operations. Globally, shipping contributes $2-3 \%$ of the emissions of $\mathrm{CO}_{2}$. The role of fisheries in that picture is very small (1-2\%) but nevertheless significant. While the fishing industry today is subject to $\mathrm{CO}_{2}$ levies to varying degrees, it is unrealistic that any industry 
in the future can escape this. Among the potential direct measures in this regard are $\mathrm{CO}_{2}$ taxes, requirements to fish in more energy-friendly ways, and purchase of $\mathrm{CO}_{2}$ quotas. There are also indirect effects: capacity reduction in the fishing fleet may generally contribute to reduced emissions, as will regulatory programmes that encourage short trips and fuel-efficient fishing practices. An important point here is also to keep stocks at high abundance levels but to fish at a low fishing mortality rate (F), which results in larger stock sizes and makes fishing more efficient, thereby requiring less energy during fishing.

\subsection{Concluding remarks}

It is clear that climate variability has a pronounced effect on various components of the marine and freshwater ecosystems. Analysis of historical data has documented changes in hydrographic and freshwater conditions as well as circulation patterns in the Nordic and Barents Seas. These in turn have influenced the abundance and distribution of planktonic species and the composition of the plankton community structure and function. Distribution of marine fish species show significant shifts in response to climate fluctuations. Although much less prominent, distributional shifts can also occur in freshwater and anadromous species, due less to active movement and more related to changes in survival rates. Species biomass is affected through changes in growth rates and recruitment. Phenological changes, such as timing of the phytoplankton blooms or fish migrations, occur in response to ocean conditions, particularly temperature.

One of the present grand challenges is to apply this knowledge to the development of marine and freshwater ecosystem scenarios under future climate change. This is required for planning purposes by the fishing industry, fisheries managers, the oil and gas industry, governments and the public. To facilitate this, scientists require regional models of future climate scenarios and ecosystem responses. Presently, future climate scenarios for regional models are obtained through downscaling of global models. While some downscaling has been carried out for the Barents Sea, improvements in the global models are needed before better regional model scenarios will be forthcoming. At the same time the understanding of the processes linking climate to ecological changes needs to be improved in order to reduce the uncertainty of predictions of the ecological consequences of future climate change. Research to improve knowledge of the mechanism linking climate and changes to the 
ecosystem structure and functioning is under way but more is required. In addition, long-term time series need to be maintained and new time series should be established in areas not presently monitored or for variables for which there are inadequate data. These will allow documentation of the changes that occur. While the task is daunting, given the progress in recent years, the future looks promising.

\subsection{References}

ACIA, 2005. Arctic Climate Impact Assessment. Cambridge, UK: Cambridge University Press. 1042 pp.

Arrigo, K.R., van Dijken, G. and Pabi, S., 2008. Impact of a shrinking Arctic ice cover on marine primary production. Geophysical Research Letters, 35, L19603, doi:10.1029/ 2008GL035028.

Berge, J., Johnsen, G., Nilsen, F., Gulliksen, B. and Slagstad, D., 2005. Ocean temperature oscillations enable reappearance of blue mussels Mytilus edulis in Svalbard after a 1000 year absence. Marine Ecology Progress, Series 303, 167-175.

Bernatchez, L. and Wilson, C.C., 1998. Comparative phylogeography of Nearctic and Palearctic fishes. Molecular Ecology, 7, 431-452.

Bethke, I., Furevik, T. and Drange, H., 2006. Towards a more saline North Atlantic and a fresher Arctic under global warming. Geophysical Research Letters, 33, L21712.

Beverton, R.J.H. and Lee, A.J., 1965. Hydrographic fluctuations in the North Atlantic Ocean and some biological consequences. In: C.G. Johnson and L.P. Smith, eds. The Biological Significance of Climate Changes in Britain. Symposia of the Institute of Biology, 14. London: Academic Press. pp.79-109.

Blacker, R.W., 1957. Benthic animals as indicators of hydrographic conditions and climatic change in Spitzbergen waters. Fisheries Investigations, Series 2(20), 1-49.

Blacker, R.W., 1965. Recent changes in the benthos of the West Spitsbergen fishing grounds. Special Publication of the International Commission on the Northwest Atlantic Fisheries, 6, 791-794.

Bogstad, B. and Gjøsæter, H., 1994. A method for estimating the consumption of capelin by cod in the Barents Sea. ICES Journal of Marine Science, 51, 273-280.

Brandt, U.S. and Kronbak, L.G., 2010. On the stability of fishery agreements under exogenous change: An example of agreements under climate change. Fisheries Research, 101, 11-19.

Browman, H., ed. 2008. Fisheries Management and Climate Change in the Northeast Atlantic Ocean and the Baltic Sea: Implications for resource management policy. TemaNord 2008, 595. 74 pp.

Brunner, P.C., Douglas, M.R. and Bernatchez, L., 1998. Microsatellite and mitochondria DNA assessment of population structure and stocking effects in Arctic charr Salvelinus alpinus (Teleostei: Salmonidae) from central alpine lakes. Molecular Ecology, 7, 209-223.

Cheung, W.W.I., Lam ,V.W.Y. and Pauly, D., 2008. Modelling present and climateshifted distribution of marine fishes and invertebrates. UBC Fisheries Centre Research Report 16(3). 72 pp. 
Cheung, W.W.I., Lam, V.W.Y., Sarmiento, J.L., Kearney, K., Watson, R. and Pauly, D., 2009. Projecting global marine biodiversity impacts under climate change scenarios. Fish and Fisheries, 3, 235-251.

Colebrook, J.M., 1978. Continuous plankton records: zooplankton and environment, North-East Atlantic and North Sea, 1948-1975. Oceanologica Acta, 1, 9-23.

Comte, L., Buisson, L., Daufresne, M. and Grenouillet, G., 2013. Climate-induced changes in the distribution of freshwater fish: observed and predicted trends. Freshwater Biology, 58, 625-639.

Drinkwater, K.F., 2005. The response of Atlantic cod (Gadus morhua) to future climate change. ICES Journal of Marine Science, 62, 1327-1337.

Drinkwater, K.F., 2006. The regime shift of the 1920s and 1930s in the North Atlantic. Progress in Oceanography, 68, 134-151.

Durner, G.M., Douglas, D.C., Nielson, R.M., Amstrup, S.C., McDonald, T.L., Stirling, I., Mauritzen, M., Born, E.W., Wiig, Ø., DeWeaver, E., Serreze, M.C., Belikov, S.E., Holland, M.M., Maslanik, J., Aars, J., Bailey, D.A. and Derocher, A.E., 2009. Predicting 21st-century polar bear habitat distribution from global climate models. Ecological Monographs, 79, 25-58.

Eide, A., 2008. An integrated study of economic effects of and vulnerabilities to global warming on the Barents Sea cod fisheries. Climate Change, 87, 251-262.

Ekerhovd, N.A., 2010. The stability and resilience of management agreements on climate-sensitive straddling fishery resources: the blue whiting (Micromesistius poutassou) coastal state agreement. Canadian Journal of Fisheries and Aquatic Sciences, 67(3), 534-552.

Ellingsen, I.H., Dalpadad, P., Slagstad, D. and Loeng, H., 2008. Impact of climatic change on the biological production in the Barents Sea. Climatic Change, 87, 155-175.

Elliott, J.M. and Elliott, J.A., 2010. Temperature requirements of Atlantic salmon Salmo salar, brown trout Salmo trutta and Arctic charr Salvelinus alpinus: predicting the effects of climate change. Journal of Fish Biology, 77, 1793-1817.

Falk-Petersen, S., Pavlov, V., Timofeev, S. and Sargent, J.R., 2007. Climate variability and possible effects on arctic food chains: The role of Calanus. In: J.B Ørbæk, R. Kallenborn, I. Tombre, E.N. Hegseth, S. Falk-Petersen and A.H. Hoel, eds. Arctic Alpine Ecosystems and People in a Changing Environment. Berlin, Heidelberg: Springer. pp.147-166.

Filin, A. and Oganin, I., 2008. Modeling the consequences of expected warming in the Barents Sea on the Atlantic cod stock. In: K. Drinkwater and C. Shrum, eds. Report of the Workshop on Cod and Future Climate Change (WKCFCC). ICES Oceanography Committee, ICES CM 2008/OCC:09. pp.72-74.

Finstad, A.G., Forseth, T., Jonsson, B., Bellier, E., Hesthagen, T., Jensen, A.J., Hessen, D.O. and Foldvik, A., 2011. Competitive exclusion along climate gradients: energy efficiency influences the distribution of two salmonid fishes. Global Change Biology, 17, 1703-1711.

Fraser, D.J., Weir, L.K., Bernatchez, L., Hansen, M.M. and Taylor, E.B., 2011. Extent and scale of local adaptation in salmonid fishes: review and meta-analysis. Heredity, 106, 404-420.

Friedland, K.D., Shank, B.V., Todd, C.D., McGinnity, P. and Nye, J.A., 2013 (in press). Differential response of continental stock complexes of Atlantic salmon (Salmo salar) to the Atlantic Multidecadal Oscillation. Journal of Marine Systems, doi:10.1016/ j.jmarsys.2013.03.003.

Furevik, T., Drange, H. and Sorteberg, A., 2002. Anticipated changes in the Nordic Seas marine climate: Scenarios for 2020, 2050 and 2080. Fisken og Havet, 4, 1-13. 
Gjøsæter, H., Bogstad, B. and Tjelmeland, S., 2009. Ecosystem effects of the three capelin stock collapses in the Barents Sea. Marine Biology Research, 5, 40-53.

Gjøsæter, H., Dalpadado, P. and Hassel, A., 2002. Growth of Barents Sea capelin (Mallotus villosus) in relation to zooplankton abundance. ICES Journal of Marine Science, 59, 959-967.

Griffiths, D., 2006. Pattern and process in the ecological biogeography of European freshwater fish. Journal of Animal Ecology, 75, 734-751.

Guðbergsson, G., 2013. Catch statistics for Icelandic rivers and lakes 2012. Report from the Institute of Freshwater Fisheries, VMST/13040. 33 pp.

Hannesson, R., 2007a. Geographical distribution of fish catches and temperature variations in the Northeast Atlantic since 1945. Marine Policy, 31, 32-39.

Hannesson, R., 2007b. Global warming and fish migrations. Natural Resource Modeling, 20, 301-319.

Hannesson, R., 2013. Sharing the Northeast Atlantic mackerel. ICES Journal of Marine Science, 70, 259-269.

Hansen, B., Christiansen, S. and Pedersen, G., 1996. Plankton dynamics in the marginal ice zone of the central Barents Sea during spring: carbon flow and structure of the grazer food chain. Polar Biology, 16, 115,-218.

Hátún, H., Payne, M., Beaugrand, G., Reid, P.C., Sandø, A.B., Drange, H., Hansen, B., Jacobsen, J.A. and Bloch, D., 2009. Large bio-geographical shifts in the north-eastern Atlantic Ocean: From the subpolar gyre, via plankton, to blue whiting and pilot whales. Progress in Oceanography, 80, 149-162.

Heath, M.R., Astthorsson, O.S., Dunn, J., Ellertsen, B., Gaard, E., Gislason, A., Gurney, W.S.C. and Hind, A.T., 2000. Comparative analysis of Calanus finmarchicus demography at locations around the Northeast Atlantic. ICES Journal of Marine Science, 57, 1562-1580.

Hedger, R., Sundt-Hansen, L., Forseth, T., Ugedal, O., Diserud, O., Kvambekk, A. and Finstad, A., 2013. Predicting climate change effects on subarctic-Arctic populations of Atlantic salmon (Salmo salar). Canadian Journal of Fisheries and Aquatic Sciences, 70, 159-168.

Hein, C.L., Öhlund, G. and Englund, G., 2011. Dispersal through stream networks: modelling climate-driven range expansions of fishes. Diversity and Distributions, 17, 641-651.

Hein, C.L., Öhlund, G. and Englund, G., 2012. Future distribution of Arctic Char Salvelinus alpinus in Sweden under climate change: effects of temperature, lake size and species interactions. Ambio, 41, 303-312.

Hein, C.L., Öhlund, G. and Englund, G., 2014. Fish introductions reveal the temperature dependence of species interactions. Proceedings of the Royal Society, B: Biological Sciences, 281, 20132641.

Hickling, R., Roy, D.B., Hill, J.K., Fox, R. and Thomas, C.D., 2006. The distributions of a wide range of taxonomic groups are expanding polewards. Global Change Biology, $12,450-455$.

Huse, G. and Ellingsen, I., 2008. Capelin migrations and climate change - a modeling analysis. Climatic Change, 87, 177-197.

IPCC, 2007. Climate Change 2007: The physical science basis. Contribution of Working Group I to the Fourth Assessment Report of the Intergovernmental Panel on Climate Change. S. Solomon, D. Qin, M. Manning, Z. Chen, M. Marquis, K.B. Averyt, M. Tignor and H.L. Miller, eds. Cambridge, UK: Cambridge University Press. 996 pp. 
IPCC, 2013. Climate Change 2013: The physical science basis. Contribution of Working Group I to the Fifth Assessment Report of the Intergovernmental Panel on Climate Change. T.F. Stocker, D. Qin, G.-K. Plattner, M. Tignor, S.K. Allen, J. Boschung, A. Nauels, Y. Xia, V. Bex and P.M. Midgley, eds. Cambridge, UK, and New York, USA: Cambridge University Press. 1535 pp.

Jonsson, B. and Jonsson, N., 2009. A review of the likely effects of climate change on anadromous Atlantic salmon Salmo salar and brown trout Salmo trutta, with particular reference to water temperature and flow. Journal of Fish Biology, 75, 2381-2447.

Keenlyside, N.S., Latif, M., Jungclaus, J., Kornblueh, L. and Roeckner, E., 2008. Advancing decadal-scale climate prediction in the North Atlantic sector. Nature, 453, 84-88.

Kjesbu, O.S., Bogstad, B., Devine, J.A., Gjøsæter, H., Howell, D., Ingvaldsen, R.B., Nash, R.D.M. and Skjæraasen, J.E., 2014. Synergies between climate and management for Atlantic cod fisheries at high latitudes. Proceedings of the National Academy of Science, doi:10.1073/pnas.1316342111.

Klemetsen, A., Amundsen, P.-A., Dempson, J.B., Jonsson, B., Jonsson, N., O'Connell, M.F. and Mortensen, E., 2003. Atlantic salmon Salmo salar L., brown trout Salmo trutta L. and Arctic charr Salvelinus alpinus (L.): a review of aspects of their life histories. Ecology of Freshwater Fish, 12, 1-59.

Kristiansen, T., Stock, C., Drinkwater, K. and Curchitser, E.N., 2014. Mechanistic insights into the effects of climate change on larval cod. Global Climate Change, doi: 10.1111/gcb.12489.

Lajus, D.L., Lajus, J.A., Dmitrieva, Z.V., Kraikovski, A.V. and Alexandrov, D.A., 2005. The use of historical catch data to trace the influence of climate on fish populations: examples from the White and Barents Sea fisheries in the 17th and 18th centuries. ICES Journal of Marine Science, 62, 1426-1435.

Lilly, G.R., Nakken, O. and Brattey, J., 2013. A review of the contributions of fisheries and climate variability to contrasting dynamics in two Arcto-boreal Atlantic cod (Gadus morhua) stocks: Persistent high productivity in the Barents Sea and collapse on the Newfoundland and Labrador Shelf. Progress in Oceanography, 114, 106-125.

Loeng, H., Brander, K., Carmack, E., Denisenko, S., Drinkwater, K., Hansen, B., Kovacs, K., Livingston, P., McLaughlin, F. and Sakshaug, E., 2005. In: Arctic Climate Impact Assessment. Cambridge, UK: Cambridge University Press. Chapter 8: Marine systems. pp.451-538.

Melsom, A., Lien, V.S. and Budgell, W.P., 2010. Using the Regional Ocean Modeling System (ROMS) to improve the ocean circulation from a GCM 20 th century simulation. Ocean Dynamics, 59, 969-981.

Midttun, L., Nakken, O. and Raknes, A., 1981. Variations in the geographical distribution of cod in the Barents Sea in the period 1977-1981. Fisken og Havet, 4, 1-16. (In Norwegian with English abstract.)

Miller, K.A., 2007. Climate variability and tropical tuna: management challenges for highly migratory fish stocks. Marine Policy, 31, 56-70.

Miller, K.A. and Munro, G.R., 2004. Climate and cooperation: A new perspective on the management of shared fish stocks. Marine Resource Economics, 19, 367-393.

Moss, B., Hering, D., Green, A.J., Aidoud, A., Becares, E., Beklioglu, M. et al., 2009. Climate change and the future of freshwater biodiversity in Europe: a primer for policymakers. Freshwater Reviews, 2, 103-130.

Mueter, F.J., Broms, C., Drinkwater, K.F., Friedland, K.D., Hare, J.A., Hunt Jr., G.L., Melle, W. and Taylor, M., 2009. Ecosystem responses to recent oceanographic variability in highlatitude Northern Hemisphere ecosystems. Progress in Oceanography, 81, 93-110. 
Mueter, F.J. and Litzow, M.A., 2008. Sea ice retreat alters the biogeography of the Bering Sea continental shelf. Ecological Applications, 18, 309-320.

Nesis, K.N., 1960. Variations in the bottom fauna of the Barents Sea under the influence of fluctuations in the hydrological regime. pp. 129-138. In: Yu. Marti, ed. Soviet Fisheries Investigations in the North European Seas. Moscow: VNIRO/PINRO Press. (In Russian with English abstract.)

Olsen, A., Johannessen. T. and Rey. F., 2003. On the nature of the factors that control spring bloom development at the entrance to the Barents Sea and their interannual variability. Sarsia, 88, 379-393.

Otero, J., L'Abee-Lund, J.H., Castro-Santos, T., Leonardsson, K., Storvik, G.O., Jonsson, B. et al., 2014. Basin-scale phenology and effects of climate variability on global timing of initial seaward migration of Atlantic salmon (Salmo salar). Global Change Biology, 20, 61-75.

Ottersen, G. and Sundby, S., 1995. Effects of temperature, wind and spawning stock biomass on recruitment of Arcto-Norwegian cod. Fisheries Oceanography, 4, 278-292.

Overland, J.E. and Wang, M., 2007. Future regional Arctic sea ice declines. Geophysical Research Letters, 34, L17705, doi:10.1029/2007GL030808.

Piepenburg, D., 2005. Recent research on Arctic benthos: common notions need to be revised. Polar Biology, 28, 733-755.

Prowse, T.D., Wrona, F.J., Reist, J., Gibson, J.J., Hobbie, J.E., Levesque, L.M.J. and Vincent, W.F., 2006a. Climate change effects on hydroecology of arctic freshwater ecosystems. Ambio, 35, 347-358.

Prowse, T.D., Wrona, F.J., Reist, J., Gibson, J.J., Hobbie, J.E., Levesque, L.M.J. and Vincent, W.F., 2006b. Historical changes in arctic freshwater ecosystems. Ambio, 35, 339-346.

Reist, J.D., Wrona, F.J., Prowse, T.D., Power, M., Dempson, J.B., King, J.R. and Beamish, R.J., 2006. An overview of effects of climate change on selected Arctic freshwater and anadromous fishes. Ambio, 35, 381-387.

Rey, F., 2004. Phytoplankton: the grass of the sea. In: H.R. Skjoldal, ed. The Norwegian Sea Ecosystem. Trondheim, Norway: Tapir Academic Press. pp.97-136.

Rey, F. and Loeng, H., 1985. The influence of ice and hydrographic conditions on the development of phytoplankton in the Barents Sea. In: J.S. Gray and M.E. Christiansen, eds. Marine Biology of Polar Regions and Effects of Stress on Marine Organisms. John Wiley and Sons Ltd. pp.49-64.

Reyjol, Y., Hugueny, B., Pont, D., Bianco, P.G., Beier, U., Caiola, N., Casals, F., Cowx, I., Economou, A., Ferreira, T., Haidvogl, G., Noble, R., De Sostoa, A., Vigneron, T. and Virbickas, T., 2007. Patterns in species richness and endemism of European freshwater fish. Global Ecology and Biogeography, 16, 65-75.

Sakshaug, E., 1997. Biomass and productivity distributions and their variability in the Barents Sea. ICES Journal of Marine Science, 54, 341-350.

Sakshaug, E. and Walsh, J.J., 2000. Marine biology: Biomass, productivity distributions and their variability in the Barents and Bering Seas. In: M. Nuttall and T.V. Callaghan, eds. The Arctic: Environment, People, Policy. Amsterdam: Harwood. pp.163-196.

Skjoldal, H.R. and Rey, F., 1989. Pelagic production and variability of the Barents Sea ecosystem. In: K. Sherman and L.M. Alexander, eds. Biomass Yields and Geography of Large Marine Ecosystems. AAAS Selected Symposium 111. Colorado, USA: Westview Press. pp.241-286.

Slagstad, D. and Wassmann, P., 1997. Climatic change and carbon flux in the Barents Sea: 3-D simulations of ice-distribution, primary production and vertical export of particulate organic carbon. Memoirs of National Institute of Polar Research, 51(Special Issue), 119-141. 
Stenevik, E.K. and Sundby, S., 2007. Impacts of climate change on commercial fish stocks in Norwegian waters. Marine Policy, 31, 19-31.

Stirling, I., Lunn, N.J. and Iacozza, J., 1999. Long-term trends in the population ecology of polar bears in western Hudson Bay in relation to climate change. Arctic, 52, 294-306.

Stroeve, J., Holland, M.M., Meier, W., Scambos, T. and Serreze, M., 2007. Arctic sea ice decline: Faster than forecast. Geophysical Research Letters. 34, L09501, doi:10.1029/2007GL029703.

Sundby, S., 2000. Recruitment of Atlantic cod stocks in relation to temperature and advection of copepod populations. Sarsia, 85, 277-298.

Sundby, S. and Nakken, O., 2008. Spatial shifts in spawning habitats of ArctoNorwegian cod related to multidecadal climate oscillations and climate change. ICES Journal of Marine Science, 65, 953-962.

Svendsen, E., Skogen, M., Budgell, P., Huse, G., Ådlandsvik, B., Vikebø, F., Stiansen, J.E., Asplin, L. and Sundby, S., 2007. An ecosystem modelling approach to predicting cod recruitment. Deep-Sea Research II, 54, 2810-2821.

Svenning, M.-A., Falkegård, M. and Hanssen, Ø.K., 2012. Sjørøya i Nord-Norge - en fallende dronning? NINA Rapport 780.61 pp. (In Norwegian.)

Sverdrup, H.U., 1953. On conditions for the vernal blooming of phytoplankton. Journal du Conseil International pour l'Exploration de la Mer, 11, 287-295.

Sætersdal, G. and Loeng, H., 1987. Ecological adaptation of reproduction in Northeast Arctic cod. Fisheries Research, 5, 253-270.

Tittensor, D.P., DeYoung, B. and Tang, C.L., 2003. Modelling the distribution, sustainability and diapauses emergence timing of the copepod Calanus finmarchicus in the Labrador Sea. Fisheries Oceanography, 12, 299-316.

Toivonen, A.L., Bengtsson, B., Geertz-Hansen, P., Guðbergsson, G., Kristofersson, D., Kyrkjebo, H., Navrud, S., Roth, E., Tuunaninen, P. and Weissglas, G., 2000. Economic value of recreational fisheries in the Nordic countries. TemaNord, 2000, 604.

Toresen, R. and Østvedt, L.J., 2000. Variation in abundance of Norwegian springspawning herring (Clupea harengus, Clupeidae) throughout the 20th century and the influence of climatic fluctuations. Fish and Fisheries, 1, 231-256.

Vilhjálmsson, H., 1997. Climatic variations and some examples of their effects on the marine ecology of Icelandic and Greenland waters, in particular during the present century. Rit Fiskideildar, 40, 7-29.

Vikebø, F.B., Sundby, S., Ådlandsvik, B. and Otterå, O.H., 2007. Impacts of a reduced thermohaline circulation on transport and growth of larvae and pelagic juveniles of Arcto-Norwegian cod (Gadus morhua). Fisheries Oceanography, 16, 216-228.

Vincent, B., Dionne, M., Kent, M.P., Lien, S. and Bernatchez, L., 2013. Landscape genomics in Atlantic salmon (Salmo salar): searching for gene-environment interactions driving local adaptation. Evolution, 67, 3469-3487.

Wassmann, P., Carmack, E., Kosobokova, K.N., Slagstad, D., Drinkwater, K.F., Hopcroft, R.R., Moore, S.E., Ellingsen, I., Nelson, J., Popova, E. and Berge, J., 2014. The contiguous domains of Arctic Ocean advection: trails of life and death. Submitted to Progress in Oceanography.

Wood, R., 2008. Natural ups and downs. Nature, 453, 43-45.

Østbye, K., Bernatchez, L., Næsje, T.F., Himberg, K.-J.M. and Hinda, K, 2005. Evolutionary history of the European whitefish Coregonus lavaretus (L.) species complex as inferred from mtDNA phylogeography and gill-raker numbers. Molecular Ecology, $14,4371-4387$. 


\section{Agricultural crops}

\subsection{Introduction}

Agricultural crops are used for a range of different purposes, from food and feed to fibre and bioenergy. In the Nordic region, crops for livestock production tend to dominate the cropping systems; however, there is wide variation in the types of crops grown throughout the Nordic countries. In the southern regions, cereal crops tend to dominate, in particular in regions where rainfall is not in excess. Much of the cereal grains are fed to livestock, in particular to monogastric animals such as pigs and poultry. In regions that are less favourable for cereal production, cropping systems tend to sustain ruminant production systems such as dairy farming and cattle and sheep production. Grasslands and forage crop production systems dominate in these agricultural systems.

Changing climatic conditions will alter the suitability of growing various crops in the Nordic countries, as well as the profitability and sustainability of agricultural practices and farming systems. The situation will not only be affected by changes in the Nordic region, but also by the increased demand for food globally (Tilman et al. 2011) as well as by changes in the suitability of crop production in other parts of the world. Conditions for crop production are expected to deteriorate under global warming in large parts of Southern Europe (Olesen et al. 2011), which would call for agricultural expansion and intensification in Northern Europe, including the Nordic countries.

\subsection{Agricultural land use}

Agricultural land use varies greatly among the Nordic countries (Table 5.1). Denmark is an intensively cultivated country with $63 \%$ of the land area used for agriculture, whereas this proportion is $16 \%$ in Iceland and less than $10 \%$ in the other Nordic countries. Of the available agricultural area, only $8 \%$ was used for arable crops in Iceland, compared to more than $80 \%$ in the other Nordic countries. Cereals constitute about $50 \%$ of the agricultural area in Denmark and Finland, but only about 30\% in Norway and Sweden, where forage crops comprise a larger proportion 
of the agricultural area. These differences are to a large extent determined by climatic and soil conditions that favour various cropping systems, primarily through effects on crop yield (Olesen and Bindi 2002).

\begin{tabular}{|c|c|c|c|c|c|}
\hline Land use & Denmark & Finland & Iceland & Norway & Sweden \\
\hline Land area, total & 4,243 & 30,389 & 10,025 & 36,527 & 41,034 \\
\hline Agricultural area, total & 2,690 & 2,286 & 1,591 & 998 & 3,066 \\
\hline Organic farmed area & 162 & 188 & 8 & 56 & 481 \\
\hline Permanent crops & 4 & 5 & - & 4 & 9 \\
\hline Temporary pastures & 566 & 667 & - & 474 & - \\
\hline Permanent pastures & 187 & 32 & 1,468 & 177 & 447 \\
\hline Arable land & 2,499 & 2,249 & 123 & 817 & 2,610 \\
\hline Irrigated area & 435 & 69 & - & 90 & 164 \\
\hline Cereals & 1,490 & 1,036 & - & 293 & 992 \\
\hline Pulses and oilseed & 131 & 57 & - & 181 & 180 \\
\hline Root and tuber & 81 & 32 & - & 13 & 64 \\
\hline Fodder crops & 879 & 650 & 150 & 486 & 1,210 \\
\hline Vegetables & 10 & 9 & - & 6 & 22 \\
\hline Fruits and berries & 11 & 11 & - & 6 & 12 \\
\hline
\end{tabular}

Source: FAOStat.

Cereal grain yields have risen in all of the Nordic countries over the past 50 years (Figure 5.1). However, most of that increase occurred before 1990 due to increased inputs of fertiliser and pesticides along with more productive varieties. Yields of wheat and barley have stagnated in Denmark, Sweden and Norway in the past 20 years and are slowing down in Finland. Throughout the period there have been consistent grain yield differences among the Nordic countries, with the highest yield in Denmark and the lowest in Finland. However, yields of both wheat and barley in Finland have recently been catching up with those in Norway. 
Figure 5.1: Developments in grain yield of wheat and barley in four Nordic countries

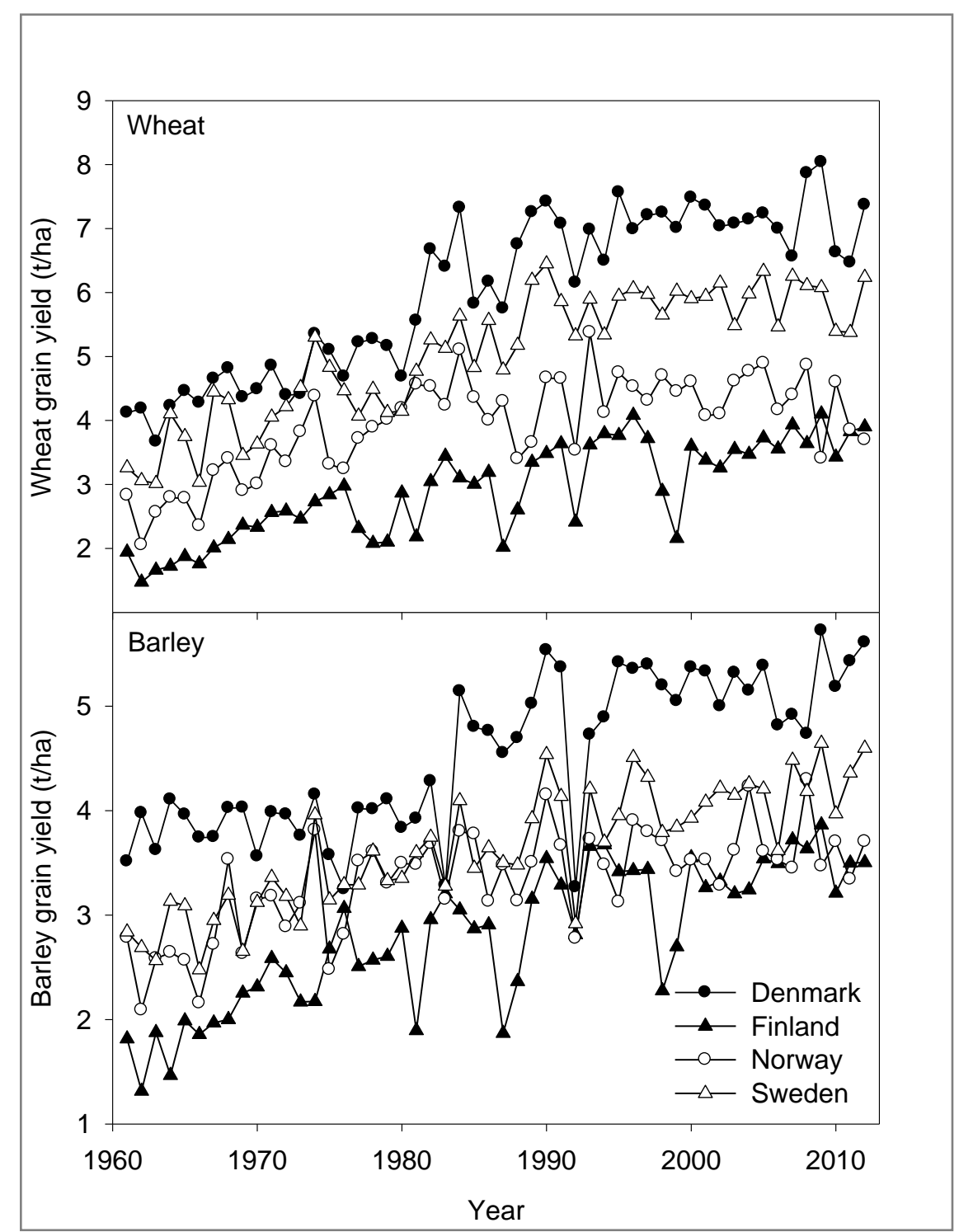

Source: FAOStat.

\subsection{Cropping systems}

The cropping systems across the Nordic region vary greatly in terms of the crops being grown and the intensity of the production and associated inputs of fertiliser and pesticides. In general, the production systems are considerably more intensive in southern parts of the Nordic region, 
such as Denmark and southern Sweden, compared with regions further north. This is an indication of the potential to grow arable crops with high yields in the southern areas, but also of the need to sustain the high yields with higher inputs.

Cultivation of crops, and their productivity and quality are directly dependent on climatic factors, in particular temperature and rainfall. Climate change is already having an impact on agriculture in Europe (Peltonen-Sainio et al. 2010), and has been attributed as one of the factors contributing to stagnation in wheat yields in parts of Europe despite continued progress in crop breeding (Brisson et al. 2010). However, such effects are mainly seen in Central and Southern Europe. In northern parts of Europe, such as Finland, warming has contributed to increased grain yields of both cereals and oilseed crops (Himanen et al. 2013). This may therefore help to explain the continued increase in cereal yields in Finland (Figure 5.1).

Climate change is expected to continue to affect agriculture in the future; the effects will vary greatly in space and may also change over time. It is generally accepted that productivity will increase in cool temperate regions such as Northern Europe due to a lengthened growing season and an extension of the frost-free period as well as to increasing $\mathrm{CO}_{2}$ concentrations (Olesen and Bindi, 2002). However, year-to-year variability in yields may also be expected to increase in regions with intensive crop production due to extreme climatic events and other factors, including pests and diseases (Kristensen et al. 2011).

\subsection{Observed changes}

The arable cropping systems in the Nordic countries are dominated by cereals, in particular winter wheat and spring barley in southern parts of the region and spring barley and oats further north. Oilseed crops, such as oilseed rape, and root and tuber crops, such as sugar beet and potato, are also among the crops grown over wider areas. Over the past decades the cultivation of high-yielding crops such as winter wheat has increased. Very recently, the cultivation of grain maize has started in southern parts of Denmark, reflecting the warming trends (Elsgaard et al. 2012). The warming has also meant a northward expansion of the area of silage maize in Northern Europe into southern Scandinavia, where the system of grass and silage maize for intensive dairy production has to a large extent replaced the traditional fodder production systems (Odgaard et al. 2011, Eckersten et al. 2014). 
Analyses of the effects of observed climate change on yield potential in Europe have shown positive effects for maize and sugar beet, which have benefited from an increase in the duration of the growing season (Supit et al. 2010). The yield benefits have been greatest in Northern Europe. The warming may also have contributed to higher yields of potato in northern regions of Europe. In contrast to this, warmer and more variable climatic conditions that also increase the risk of drought have led to a decrease in crop yields in parts of central Europe.

In parts of the Nordic countries with wet and cool climates, cropping systems with grasslands and food production for ruminant livestock tend to dominate. At higher latitudes, timothy and perennial ryegrass are the most important forage grasses, and in cold and snow-rich regions, timothy outcompetes perennial ryegrass due to better winter survival (Höglind et al. 2013). Due to the higher productivity and better feed quality of ryegrass compared to timothy, the observed warming leading to lower risk of winter kill may be expected to have already shifted the cultivation of grassland species in Norway and Sweden northwards. This is also related to extended duration of the grazing season (Uleberg et al. 2014).

\subsection{Climate effects on crops}

Increasing GHG emissions and associated climate changes will affect agroecosystems either directly (primarily by increasing photosynthesis at higher $\mathrm{CO}_{2}$ ) or indirectly via effects on the climate (e.g. temperature and rainfall that affect several aspects of the functioning of cropping systems) (Table 5.2). The effects may also be direct through changes in crop physiology or indirect through effects on soil fertility, crop protection (weeds, pests or disease) or on the ability to perform crop management in the right time window. The exact responses will depend on the sensitivity of the particular agricultural system and on the relative changes in controlling factors. 
Table 5.2: Influence of $\mathrm{CO}_{2}$, temperature, rainfall and wind on various components of the agroecosystem

\begin{tabular}{|c|c|c|c|}
\hline \multirow[t]{2}{*}{ Component } & \multicolumn{3}{|c|}{ Influence of factor } \\
\hline & $\mathrm{CO} 2$ & Temperature & Rain/wind \\
\hline Plants & $\begin{array}{l}\text { Higher } \mathrm{CO} 2 \text { leads to in- } \\
\text { creased dry matter growth } \\
\text { and decrease in water use. }\end{array}$ & $\begin{array}{l}\text { Increase of temperature boosts } \\
\text { yield up to a threshold beyond } \\
\text { which yield declines. }\end{array}$ & $\begin{array}{l}\text { Decreasing precipita- } \\
\text { tion or increasing wind } \\
\text { decreases dry matter } \\
\text { growth. }\end{array}$ \\
\hline Water & $\begin{array}{l}\text { Higher } \mathrm{CO} 2 \text { conserves soil } \\
\text { moisture by reducing } \\
\text { transpiration. }\end{array}$ & $\begin{array}{l}\text { Higher temperatures increase } \\
\text { evaporation, leading to higher } \\
\text { irrigation demands and in dry } \\
\text { environments to salinisation. }\end{array}$ & $\begin{array}{l}\text { Higher rainfall will } \\
\text { increase groundwater } \\
\text { supply and in some } \\
\text { areas increase } \\
\text { groundwater levels. }\end{array}$ \\
\hline Soil & $\begin{array}{l}\text { Higher carbon concentra- } \\
\text { tions of plant residues under } \\
\text { higher } \mathrm{CO} 2 \text { will lead to } \\
\text { higher soil carbon content. }\end{array}$ & $\begin{array}{l}\text { Higher temperatures boost soil } \\
\text { organic matter turnover, leading } \\
\text { to reduced soil carbon content } \\
\text { but temporarily higher nutrient } \\
\text { supply for plants. }\end{array}$ & $\begin{array}{l}\text { Drier and windier } \\
\text { environments may lead } \\
\text { to enhanced wind } \\
\text { erosion, whereas more } \\
\text { intense rainfall will } \\
\text { enhance water erosion. }\end{array}$ \\
\hline Pests/disease & $\begin{array}{l}\text { Higher } \mathrm{CO} 2 \text { reduces the } \\
\text { quality of plant biomass for } \\
\text { pests and disease, leading to } \\
\text { fewer pests. }\end{array}$ & $\begin{array}{l}\text { Higher temperatures reduce the } \\
\text { generation time of pests and } \\
\text { disease and cause attacks to } \\
\text { occur earlier in the year, making } \\
\text { pests and disease more prob- } \\
\text { lematic. }\end{array}$ & $\begin{array}{l}\text { Some diseases are } \\
\text { spread by wind or } \\
\text { rainfall. Therefore } \\
\text { more rainy and windy } \\
\text { conditions will favour } \\
\text { some diseases. }\end{array}$ \\
\hline Weeds & $\begin{array}{l}\text { Enhanced } \mathrm{CO} 2 \text { concentra- } \\
\text { tions will differentially } \\
\text { favour crop and weed } \\
\text { species. This may make } \\
\text { some weeds more problem- } \\
\text { atic. Higher } \mathrm{CO} 2 \text { will also } \\
\text { reduce the efficacy of some } \\
\text { herbicides. }\end{array}$ & $\begin{array}{l}\text { Higher temperatures will lead to } \\
\text { invasive weed species in some } \\
\text { regions and will also affect the } \\
\text { efficacy of herbicides. }\end{array}$ & $\begin{array}{l}\text { More rainy conditions } \\
\text { may make some weed } \\
\text { species more difficult } \\
\text { to control with herbi- } \\
\text { cides. }\end{array}$ \\
\hline
\end{tabular}

\subsubsection{Carbon dioxide}

Increasing atmospheric $\mathrm{CO}_{2}$ concentrations stimulate yield of crops that have a C3 photosynthesis pathway. This constitutes almost all crops grown in the Nordic region. A doubling of atmospheric $\mathrm{CO}_{2}$ concentration will lead to yield increases of $20-40 \%$ for most of these crops. The response is considerably smaller for C4 plants, which include tropical grasses such as maize. Higher $\mathrm{CO}_{2}$ concentrations not only increase photosynthesis, but also reduce plant water consumption. This may improve tolerance of plants to drier conditions, thus resulting in higher yields under dry or drought conditions.

Higher $\mathrm{CO}_{2}$ concentrations also affect the quality of the plant biomass because plants accumulate more sugar which leads to higher carbon content in leaves, stems and reproductive organs. This will in some cases have negative consequences for the quality of the food and feed. The attractive- 
ness of plants to pests and disease will also change; in some cases it may make the plants more resistant to attack. However, weeds will also benefit from increased $\mathrm{CO}_{2}$, and in some cases new measures will be needed to control them, as the efficacy of herbicides may be reduced.

\subsubsection{Temperature and rainfall}

Temperature affects crops in different ways, including the timing of crop phenological phases (crop development), the efficiency of energy capture, conversion and storage (crop growth), and the crop water supply, since temperature affects evapotranspiration. With warming, the start of active growth is advanced, plants develop faster, and the potential growing season is extended. This may have the greatest effect in colder regions (Trnka et al. 2011), and may be beneficial for perennial crops or crops that remain in their vegetative phase, e.g. sugar beets and grasslands.

Increased temperature reduces crop duration of determinate species (plants that flower and mature). This applies to all cereals and seed plants such as pulses and oilseed crops. With regard to wheat, an increase of $1^{\circ} \mathrm{C}$ during grain fill reduces the length of this phase by $5 \%$, and yield declines by a similar amount (Olesen et al. 2000). However, in the Nordic countries such reductions in crop duration can often be more than offset by shifting to cultivars with longer growth duration (Olesen et al. 2012), and this may even lead to improved yields with potentially longer growing seasons at high latitudes (Montesino-San Martin et al. 2014).

The different crop yield responses to increasing temperature in plants with different crop development responses are illustrated in Figure 5.2. The largest reduction in grain yield was simulated for winter wheat, where growth duration is reduced, because any changes in sowing date would have little effect on the duration of the vegetative and reproductive phases in spring and summer. This response concurs well with the observed response of winter wheat yields in Denmark, where the largest reductions were found to be related to high temperatures during the grain filling phase (Kristensen et al. 2011). Figure 5.2 shows a smaller response of spring barley to higher temperatures because this crop can be sown earlier in spring, thus maintaining a productive growing season. In contrast, the simulation showed an increase in yields for a grass crop, which represents crops with a non-determinate growth pattern where the yields depend on the total duration of the growing season as well as suitable temperatures and rainfall. 
Figure 5.2: Mean simulated change in yield of winter wheat, spring barley and ryegrass at increasing temperatures for a site in Denmark. The simulations were performed with the CLIMCROP model assuming that water shortages would not affect yields

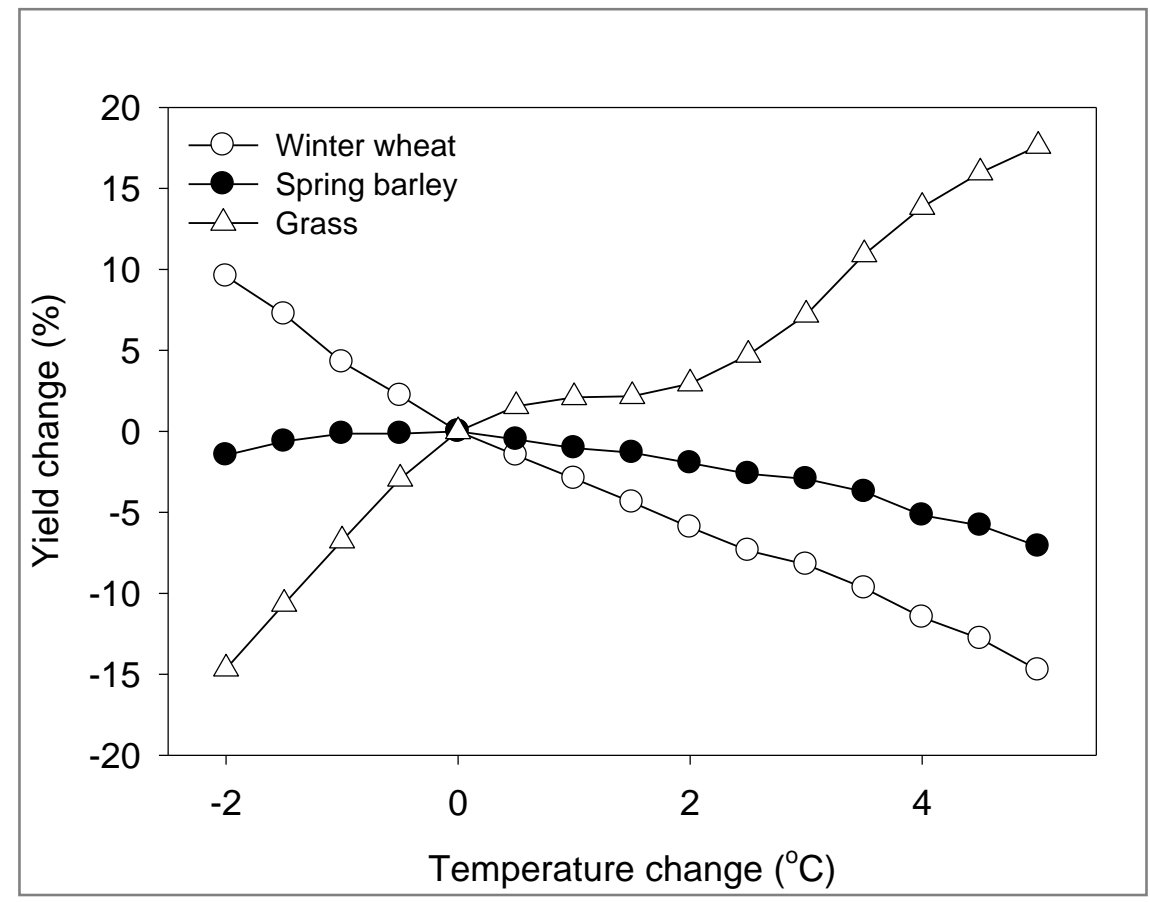

Source: Olesen et al. (2000), Olesen (2005).

Crops also show threshold responses to high temperatures. This may lead to drastic reductions in yield from short episodes of high temperatures during sensitive crop growth phases such as the reproductive period. Temperatures above $35^{\circ} \mathrm{C}$ during the flowering period can thus severely affect seed and fruit set and in turn greatly reduce yields (Porter and Semenov 2005). High temperatures will also greatly increase evapotranspiration, leading to higher risk of drought if rainfall is insufficient to compensate for water losses. Such high temperature stresses are less likely to have a severe impact on crop yields in the Nordic countries.

Peltonen-Sainio et al. (2010) characterised the coincidence of yield variations with weather variables for major field crops using long-term datasets to reveal whether there are commonalities across the European agricultural regions. Long-term national and/or regional yield datasets from 14 European countries were used for spring and winter barley and wheat, winter oilseed rape, potato and sugar beet. Harmful effects of high precipitation during grain filling in grain and seed crops and at flowering in oilseed rape were recorded. In potato, reduced precipita- 
tion at tuber formation was associated with yield penalties. Elevated temperature had harmful effects on cereals and rapeseed yields. Similar harmful effects of rainfall and high temperature on grain yield of winter wheat were found by Kristensen et al. (2011) in a study using observed winter wheat yields from Denmark.

\subsubsection{Projected changes}

Climate change is projected to lead to more favourable conditions for crop production in the Nordic countries as can be seen from effects on agroclimatic indicators (Table 5.3). These indicators show a substantial lengthening of the growing season by one month in 2050 in the northern regions, but by much less in the southern parts of Scandinavia. There will be fewer effects on the potential for crop yield, since growth during the winter half-year will still be constrained by low solar radiation. The Nordic region is expected to be less affected by summer drought than regions further south in Europe, although this risk may increase in eastern parts of the Nordic region.

\begin{tabular}{|c|c|c|c|c|c|}
\hline Zone & $\begin{array}{r}\text { Effective solar } \\
\text { radiation (\%) }\end{array}$ & $\begin{array}{r}\text { Effective growing } \\
\text { days (days) }\end{array}$ & $\begin{array}{l}\text { Date of last } \\
\text { frost (days) }\end{array}$ & $\begin{array}{r}\text { Dry days in } \\
\text { spring (\%) }\end{array}$ & $\begin{array}{r}\text { Dry days in } \\
\text { summer (\%) }\end{array}$ \\
\hline $\begin{array}{l}\text { Alpine North (Norway and } \\
\text { northern Sweden) }\end{array}$ & 8 & 29 & -10 & 1 & -2 \\
\hline $\begin{array}{l}\text { Boreal (Finland, central } \\
\text { Sweden, parts of Norway) }\end{array}$ & 8 & 16 & -11 & -1 & 2 \\
\hline $\begin{array}{l}\text { Nemoral (south-central } \\
\text { Sweden) }\end{array}$ & 8 & 12 & -10 & 1 & 11 \\
\hline $\begin{array}{l}\text { Atlantic North (western } \\
\text { Denmark) }\end{array}$ & -1 & 5 & -11 & -4 & 21 \\
\hline $\begin{array}{l}\text { Continental (eastern } \\
\text { Denmark, southern Sweden) }\end{array}$ & -6 & -6 & -12 & -2 & 20 \\
\hline
\end{tabular}

Source: Trnka et al. (2011).

Global warming will expand the area of cereal cultivation northwards, and in the Nordic region into areas previously dominated by grassland and fodder production. It will also mean a shift in the cereals crops being grown, towards winter cereals and spring cereals with a longer growth duration, including maize in southern parts of the region (Elsgaard et al. 2012). However, with more extreme climate changes, crop yields of cur- 
rent cereal crops such as spring barley may decrease, even in Finland (Rötter et al. 2011, 2013).

The composition of grasslands and the growth of fodder crops such as silage maize will also shift northwards, not only in response to higher yields, but also in response to changes in crop quality (Eckersten et al. 2014). For grasslands, a warmer and wetter winter climate in northern parts of the Nordic region may bring with it increasing problems relating to ice cover and encasement due to more variable temperatures in winter, which in turn will lead to repeated melting and refreezing cycles of snow (Höglind et al. 2010). This will favour the grassland species that best tolerate such conditions, and may halt the northward expansion of perennial ryegrass, since timothy generally tolerates such winter conditions better.

\subsection{Soils}

Soils have many functions, including the supply of water and nutrients to growing crops, which are essential for sustaining crop production. Soils are also important for regulating the water and nutrient cycles for carbon storage and GHG emissions. In addition, soils are habitats for many organisms that contribute to the functioning of soils and agroecosystems, including effects on crop yield. Increasing temperatures will speed up decomposition where soil moisture allows, so direct climate impacts on cropland soils will tend to decrease soil organic stocks, unless this is counterbalanced by larger inputs of organic matter in crop residues (Falloon and Betts 2010).

Any reduction in soil organic matter stocks can lead to a decrease in fertility and biodiversity, loss of soil structure, reduced soil water infiltration and retention capacity, and increased risk of erosion and compaction. All of this may potentially lead to lower productivity of crops growing in the soils. Changes in rainfall and wind patterns can lead to an increase in erosion in vulnerable soils, in particular where poor cover from crops and crop residues increases susceptibility to erosion. Also, increasing frequency of freeze and thawing cycles during winter in combination with enhanced rainfall may greatly intensify soil erosion (Ulén et al. 2014). In addition to depleting soil fertility, this erosion may also heighten nutrient runoff to sensitive aquatic ecosystems (Jeppesen et al. 2009).

Faster decomposition of soil organic matter at higher temperatures increases degradation of soil organic nitrogen, which may increase the risk of nitrate leaching during periods of no or little crop cover when there is a precipitation surplus and runoff or percolation through the 
soil profile. Particularly in the Nordic region, this may increase the risk of nitrate leaching to surface and groundwater systems, thus leading to a decline in environmental quality (Patil et al. 2012).

\subsection{Crop protection}

The majority of pest and disease problems are closely linked to their host crops. Introduction of new crops will therefore also mean new pest and disease problems. Also, in currently cool regions, higher temperatures favour the proliferation of insect pests because many insects can complete a greater number of reproductive cycles. Warmer winter temperatures will also allow pests to overwinter in areas where they are now limited by cold, thus causing greater and earlier infestation during the following crop season (Roos et al. 2011). Climate warming will lead to earlier insect spring activity and proliferation of some pest species, and will also favour some of the viral diseases spread by insects. A similar situation may be seen for plant diseases, leading to an increased demand for pesticide control.

Unlike pests and diseases, weeds are directly influenced by changes in atmospheric $\mathrm{CO}_{2}$ concentrations. Differential effects of $\mathrm{CO}_{2}$ and climate changes on crops and weeds will alter the weed-crop competitive interactions, sometimes to the benefit of the crop and sometimes to the weeds. Interaction with other biotic factors and with changing temperature and rainfall may also influence weed seed survival and thus weed population development.

Changes in climatic suitability will lead to invasions of weeds, pests and diseases that are adapted to warmer climatic conditions. The speed at which such invasive species invade will depend on the rate of climatic change, on the dispersal rate of the species and on measures taken to combat non-indigenous species. The dispersal rate of pests and diseases is often so high that the geographical extent is determined by the range of climatic suitability. The Colorado beetle and the European cornborer are examples of pests and diseases that are expected to show a considerable northward expansion in Europe under climatic warming (Olesen et al. 2011). 


\subsection{Extreme events and climatic variability}

Extreme weather events, such as spells of high temperature, heavy storms or droughts, can severely disrupt crop production. Individual extreme events will usually not have lasting effects on the agricultural system. However, when the frequency of such events increases, agriculture needs to respond either by adapting or by ceasing activity.

Crops often respond nonlinearly to changes in growing conditions and have threshold responses, which greatly increase the importance of climatic variability and frequency of extreme events for absolute yield, yield stability and quality. Thus an increase in temperature variability will increase yield variability and also result in a reduction in mean yield. Even in the Nordic region there may be an increase in climatic variability that will significantly affect crop yields (Kristensen et al. 2011), although this is expected to be more severe in other parts of the world.

\subsection{Adaptation}

Farmers are already adapting to climate change, as they continually experiment with new cropping techniques. The most successful techniques quickly spread throughout the farming community, where agricultural advisors and researchers are ready to compile and disseminate new results. This also leads to adaptation to changing climatic conditions, as can be seen in the northward spread of silage maize into Denmark and southern Sweden.

Adaptation only works to the extent that the basic resources for crop growth are maintained and the climate allows for proper soil and crop management (Table 5.4). In northern areas, climate change may produce positive effects on agriculture through the introduction of new crop species and varieties, higher crop productivity and expansion of suitable areas for crop cultivation. Potential disadvantages include an increased need for plant protection, the risk of nutrient leaching and the turnover of soil organic matter. 
Table 5.4: Resource-based policies to support adaptation of agricultural systems to climate change

\begin{tabular}{|c|c|}
\hline Resource & Policy \\
\hline Land & $\begin{array}{l}\text { Reforming agricultural policy to encourage flexible land use. The great extent of } \\
\text { cropland in diverse climates in the Nordic countries will provide diversity for adapta- } \\
\text { tion. }\end{array}$ \\
\hline Water & $\begin{array}{l}\text { Reforming water management to ensure balance between maintaining the amount } \\
\text { and quality of water resources and the ecosystems they support with the water } \\
\text { resources needed for agricultural production. Climate change will affect the need for } \\
\text { both irrigation and drainage, and depending on location this will have consequences } \\
\text { for water resources and their ecological quality and will affect the need to revise } \\
\text { management and governance schemes. }\end{array}$ \\
\hline Nutrients & $\begin{array}{l}\text { Improving nutrient use efficiencies through changes in cropping systems and devel- } \\
\text { opment and adoption of new nutrient management technologies. Nutrient manage- } \\
\text { ment must be tailored to the changes in crop production resulting from climate } \\
\text { change, and utilisation efficiencies must be increased, especially for nitrogen, in order } \\
\text { to reduce emissions to water and air. }\end{array}$ \\
\hline Agrochemicals & $\begin{array}{l}\text { Support for integrated pest management systems (IPMS) should be increased through } \\
\text { a combination of education, regulation and taxation. There will be a need to adapt } \\
\text { existing IPMS to changing climatic regimes. }\end{array}$ \\
\hline Energy & $\begin{array}{l}\text { Improving the efficiency of food production and exploring new biological fuels and } \\
\text { ways to store more carbon in trees and soils. A reliable and sustainable energy supply } \\
\text { is essential for many climate adaptations and for mitigation policies. There are also } \\
\text { many options for reducing energy use in agriculture. }\end{array}$ \\
\hline Genetic diversity & $\begin{array}{l}\text { Assembling, preserving and characterising plant and animal genes and conducting } \\
\text { research on alternative crops and animals. Genetic diversity and new genetic material } \\
\text { will provide important basic material for adapting crop species to changing climatic } \\
\text { conditions, e.g. by improving tolerance to adverse conditions. }\end{array}$ \\
\hline Research capacity & $\begin{array}{l}\text { Encouraging research on adaptation, developing new farming systems and developing } \\
\text { alternative foods. Greater investment in agricultural research may provide new } \\
\text { sources of knowledge and technology for adaptation to climate change. }\end{array}$ \\
\hline Information systems & $\begin{array}{l}\text { Enhancing national systems that disseminate information on agricultural research and } \\
\text { technology, and encouraging information exchange among farmers. Fast and efficient } \\
\text { dissemination and exchange of information to and among farmers using new tech- } \\
\text { nologies (e.g. the Internet) will speed up the rate of adaptation to climatic and market } \\
\text { changes. }\end{array}$ \\
\hline Culture & $\begin{array}{l}\text { Integrating environmental, agricultural and cultural policies to preserve the heritage } \\
\text { of rural environments in a new environment. Integration of policies will be required } \\
\text { to maintain and preserve the heritage of rural environments that are dominated by } \\
\text { agricultural practices influenced by climate. }\end{array}$ \\
\hline
\end{tabular}

Source: Olesen and Bindi (2002).

The responsiveness of cropping systems to climate change depends on many factors, including how current crops are being affected by changes in the climate and what the options are for modifying the cropping system to reduce negative consequences and take advantage of new opportunities. The capacity of agriculture in the Nordic countries to adapt to future changes is generally believed to be good because in many cases changes may be favourable to production and the region has high re- 
search, educational and advisory capability (Table 5.4). However, there may be obstacles to adaptation, not least posed by current agricultural and environmental policies, which may have to be adjusted to ensure effective adaptation.

\subsection{Perspectives}

Contributing successfully to global food security and optimising the potential for mitigating agricultural GHG emissions will require a focus on sustainable intensification of the agricultural production (Tilman et al. 2011). Since the Nordic region in agricultural terms will generally be favourably affected by modest climate change, this puts this region at a relative advantage in relation to food production. It may also be said that areas in which the effect of climate change will be favourable have a moral responsibility to sustain global food production, thereby making up for losses in areas where the effect is less favourable.

The challenge in the Nordic region will be to ensure sustainable growth in agricultural production without negatively affecting the environment and natural resources. This will most likely require the development of new production systems based on perennial crops such as grasses, miscanthus and willow for processing in biorefineries before use as food, feed, biomaterials and bioenergy (Smith and Olesen 2011). Predicted climate changes in the Nordic region, together with a highly skilled farming industry, will provide good opportunities for implementing new agricultural production systems with substantially higher productivity at lower environmental costs.

\subsection{References}

Brisson, N., Gate, P., Gouache, D., Charmet, G., Oury, F.X. and Huard, F., 2010. Why are wheat yields stagnating in Europe? A comprehensive data analysis for France. Field Crops Research, 119, 201-212.

Eckersten, H., Herrmann, A., Kornher, A., Halling, M., Sindhøj, E. and Lewan, E., 2014. Predicting silage maize yield and quality in Sweden as influenced by climate change and variability. Acta Agriculturae Scandinavica, Section B - Soil and Plant Science, 62, 151-165.

Elsgaard, L., Børgesen, C.D., Olesen, J.E., Siebert, S., Ewert, F., Peltonen-Sainio, P., Rötter, R.P. and Skjelvåg, A.O., 2012. Shifts in comparative advantages for maize, oat, and wheat cropping under climate change in Europe. Food Additives and Contaminants, 29, 1514-1526. 
Falloon, P. and Betts, R., 2010. Climate impacts on European agriculture and water management in the context of adaptation and mitigation - The importance of an integrated approach. Science of the Total Environment, 408, 5667-5687.

Himanen, S.J., Hakala, K. and Kahiluoto, H., 2013. Crop responses to climate and socioeconomic change in northern regions. Regional Environmental Change, 13, 17-32.

Höglind, M., Bakken, A.K., Jørgensen, M. and Østrem, L., 2010. Tolerance to frost and ice encasement in cultivars of timothy and perennial ryegrass during winter. Grass and Forage Science, 65, 431-445.

Höglind, M., Thorsen, S.M. and Semenov, M.A., 2013. Assessing uncertainties in impact of climate change on grass production in Northern Europe using ensembles of global climate models. Agricultural and Forest Meteorology, 170, 103-113.

Jeppesen, E., Kronvang, B., Meerhoff, M., Søndergaard, M., Hansen, K.M., Andersen, H.E., Lauridsen, T.L., Liboriussen, L., Bekioglu, M., Ozen, A. and Olesen, J.E., 2009. Climate change effects on runoff, phosphorus loading and lake ecological state, and potential adaptations. Journal of Environmental Quality, 38, 1930-1941.

Kristensen, K., Schelde, K. and Olesen, J.E., 2011. Winter wheat yield response to climate variability in Denmark. Journal of Agricultural Science, 149, 33-47.

Montesino-San Martin, M., Olesen, J.E. and Porter, J.R., 2014. A genotype, environment and management (GxExM) analysis of adaptation in winter wheat to climate change in Denmark. Agricultural and Forest Meteorology, 187, 1-13.

Odgaard, M.V., Bøcher, P.K., Dalgaard, T. and Svenning, J.-C., 2011. Climatic and nonclimatic drivers of spatiotemporal maize-area dynamics across the northern limit for maize production. A case study for Denmark. Agriculture, Ecosystems and Environment, 142, 291-302.

Olesen, J.E. and Bindi, M., 2002. Consequences of climate change for European agricultural productivity, land use and policy. European Journal of Agronomy, 16, 239-262.

Olesen, J.E., Jensen, T. and Petersen, J., 2000. Sensitivity of field-scale winter wheat production in Denmark to climate variability and climate change. Climate Research, $15,221-238$.

Olesen, J.E., 2005. Climate change and $\mathrm{CO}_{2}$ effects on productivity of Danish agricultural systems. Journal of Crop Improvement, 13, 257-274.

Olesen, J.E., Trnka, M., Kersebaum, K.C., Skjelvåg, A.O., Seguin, B., Peltonen-Sainio, P., Rossi, F., Kozyra, J. and Micale, F., 2011. Impacts and adaptation of European crop production systems to climate change. European Journal of Agronomy, 34, 96-112.

Olesen, J.E., Børgesen, C.D., Elsgaard, L., Palosuo, T., Rötter, R., Skjelvåg, A.O., Peltonen-Sainio, P., Börjesson, T., Trnka, M., Ewert, F., Siebert, S., Brisson, N., Eitzinger, J., van der Fels-Klerx, H.J. and van Asselt, E., 2012. Changes in flowing and maturity time of cereals in Northern Europe under climate change. Food Additives and Contaminants, 29, 1527-1542.

Patil, R., Lægdsmand, M., Olesen, J.E. and Porter, J.R., 2012. Sensitivity of crop yield and $N$ losses in winter wheat to changes in mean and variability of temperature and precipitation in Denmark using the FASSET model. Acta Agriculturae Scandinavica, Section B - Plant and Soil, 62, 335-351.

Peltonen-Sainio, P., Jauhianinen, J., Trnka, M., Olesen, J.E., Calanca, P.L., Eckersten, H., Eitzinger, J., Gobin, A., Kersebaum, C., Kozyra, J., Kumar, S., Marta, A., Micale, F., Schaap, B., Seguin, B., Skjelvåg, A. and Orlandini, S., 2010. Coincidence of variation in yield and climate in Europe. Agriculture, Ecosystems and Environment, 139, 483-489.

Porter, J.R. and Semenov, M.A., 2005. Crop responses to climatic variation. Philosophical Transactions of the Royal Society, B 360, 2021-2035. 
Roos, J., Hopkins, R., Kvarnheden, A. and Dixelius, C., 2011. The impact of global warming on plant diseases and insect vectors in Sweden. European Journal of Plant Pathology, 129, 9-19.

Rötter, R.P., Palosuo, T., Pirttioja, N.K., Dubrovsky, M., Salo, T., Fronzek, S., Aikasalo, R., Trnka, M., Ristolainen, A. and Carter, T.R., 2011. What would happen to barley production in Finland if global warming exceeded $4^{\circ} \mathrm{C}$ ? A model-based assessment. European Journal of Agronomy, 35, 205-214.

Rötter, R.P., Höhn, J., Trnka, M. Fronzek, S., Carter, T.R. and Kahiluoto, H., 2013. Modelling shifts in agroclimate and crop cultivar response under climate change. Ecology and Evolution, 3, 4197-4212.

Smith, P. and Olesen, J.E., 2010. Synergies between mitigation of, and adaptation to, climate change in agriculture. Journal of Agricultural Science, 148, 543-552.

Supit, I., van Diepen, C.A., de Wit, A.J.W., Wolf, J., Kabat, P., Baruth, B., and Ludwig, F., 2012. Assessing climate change effects on European crop yields using the Crop Growth Monitoring System and a weather generator. Agricultural and Forest Meteorology, 164, 96-111.

Tilman, D., Balzer, C., Hill, J. and Befort, B.L., 2011. Global food demand and the sustainable intensification of agriculture. Proceedings of the National Academy of Sciences of the United States of America, 108, 20260-20264.

Trnka, M., Olesen, J.E., Kersebaum, K.C., Skjelvåg, A.O., Eitzinger, J., Seguin, B., Peltonen-Sainio, P., Orlandini, S., Dubrovsky, M., Hlavinka, P., Balek, J., Eckersten, H., Cloppet, E., Calanca, P., Rötter, R., Gobin, A., Vucetic, V., Nejedlik, P., Kumar, S., Lalic, B., Mestre, A., Rossi, F., Alexandrov, V., Kozyra, J., Schaap, B. and Zalud, Z., 2011. Agroclimatic conditions in Europe under climate change. Global Change Biology, 17, 2298-2318.

Uleberg, E., Hassen-Bauer, I., van Oort, B. and Dalmannsdottir, S., 2014. Impact of climate change on agriculture in Northern Norway and potential strategies for adaptation. Climatic Change, 122, 27-39.

Ulén, B., Bechmann, M., Øygaarden, L. and Kyllmar, K., 2014. Soil erosion in Nordic countries - future challenges and research needs. Acta Agriculturae Scandinavica, Section B - Soil and Plant Science, 62, Supplement 2, 176-184. 


\section{Livestock}

\subsection{Background}

Climate change resulting in increased temperature and more frequent extreme weather events is expected to have an impact on animal production through:

- Changes in production of feed.

- Changes in possibilities for grazing.

- Direct heat effects on animals.

- Increased risk of disease.

- In addition, animal production can contribute to the mitigation of climate change through.

- Reduction of GHG emissions.

- Carbon sequestration in soils through grazing.

Climate change may have a severe impact on world agriculture and livestock production due to increases in air temperature and rainfall and a higher incidence of extreme weather events such as drought and floods. The latter may disrupt regular agricultural practice, including livestock losses due to heat stress, disease outbreaks and feed shortages. However, in the Nordic countries some benefits of climate change are expected: higher temperatures may give higher yields and more favourable conditions for growing protein-rich crops such as peas and rapeseed. The warming climate may also lead to a longer thermal growing season due to earlier springs, which may provide an opportunity to increase the frequency of harvesting, e.g. of roughages. On the other hand, increased rainfall may reduce yields and complicate harvesting that depends on heavy machinery. As a consequence, climate change overall is expected to limit feed availability both nationally and internationally and increase the price of feed and livestock products imported to the Nordic countries. This may force livestock production into production systems where a larger amount of feed comes from by-products (e.g. straw) and marginal land (e.g. pastures) (Åby et al. 2014). 
Increasing exposure of the animals to vector- and food-borne diseases and the introduction of new diseases may also be expected in the wake of climate change. Examples of diseases that may spread northwards include bluetongue, several tick-borne diseases, West Nile fever, leishmaniasis and African horse sickness (Åby et al. 2014).

There is a risk that livestock-related GHG emissions will increase in the future. The human population will continue to grow and the demand for animal products will increase both globally and in the Nordic countries. This may lead to an increase in domestic animal populations, and the mitigation and adaptation issues related to livestock production will become increasingly important (Åby et al. 2014, Kantanen et al., in preparation).

Air temperature, humidity, air movement, solar radiation and precipitation are environmental factors that affect daily weather conditions and thus have a direct impact on animal welfare, especially of animals prone to heat stress (Robinson 2001, Nardone et al. 2006). In the Nordic countries, ruminant farm animal species typically graze, either continuously (small ruminants) or periodically (cattle), from spring to the late autumn (reindeer and honeybees are kept outside all year round) and thus are subjected to the direct effects of climate change more than monogastric species, where farming is more industrialised.

\subsection{Climate change effects on livestock production}

\subsubsection{Disease risks}

An already existing problem associated with climate change is the occurrence of new and increased frequency of existing animal diseases. The unfavourable effects of this on animal welfare and livestock production will increase. Global warming and more frequent extreme meteorological events (droughts and increased rainfall) will facilitate favourable microenvironments and microclimates for various viruses, their vector species, fungal or bacterial pathogens. New viral vector-borne diseases may not necessarily originate from nearby geographical regions but may instead spread from outside Europe. An example here is bluetongue disease, where climate change has allowed the midge (Culicoides imicola) that acts as a vector for the disease-causing virus to expand its distribution northwards in Europe (Purse et al. 2006). Models based on predicted temperature change have been used to document the risk of bluetongue and other potentially emerging pathogens and vectors becoming established in the Nordic region (see www.nordrisk.dk). This calls for a 
continued cross-national surveillance programme and optimisation of management routines to prevent and/or detect previously unknown diseases. In general, blood-sucking midges (Culicoides spp.) are one of the major threats to animal welfare, as they spread viruses that cause serious diseases in animals. Furthermore, ticks, mosquitoes and lymnaeid snails can transmit extremely harmful diseases to livestock. The increased annual temperature, milder winters and higher rainfall will favour the propagation of helminth parasites, resulting in disease and pronounced negative effects on the welfare of grazing cattle and sheep (Kantanen et al., in preparation).

\subsubsection{General heat stress}

Animals can suffer from occasional heat stress during the summer seasons even in Northern Europe. Ravagnolo et al. (2000) estimated that when the temperature is $+25{ }^{\circ} \mathrm{C}$ and relative humidity is around $50 \%$, lactating cows are outside of their optimal ambient temperature. When relative humidity increases, the threshold temperature decreases. There are differences between species and breeds within species in tolerating heat stress. The ability of ruminants to thermoregulate is typically better than that of monogastric species (Nardone et al. 2006). In addition, modern, highly-productive farm animal breeds, which typically show increased metabolic heat production, may tolerate extreme climatic conditions less well than moderate and low-output breeds (Nardone et al. 2006, Hoffman 2010 and references therein).

A clear negative relationship between the Thermal Heat Index (a combination of temperature and humidity) and both milk yield and fertility has been found in dairy cattle. Several energy-requiring physiological and metabolic functions, such as an increase in respiration, increase in water intake and reduced feed intake, are needed to keep body temperature at a comfortable level, resulting in lower productivity and fertility (Ravagnolo et al. 2000, Nardone et al. 2006). Highly productive cows were found to be more vulnerable to the negative effects of high temperatures than lower yielding cows, as a result of their high metabolic rate. In addition to production losses, heat stress will also increase the risk of disease and mortality. Negative effects have also been documented on the growth rate of pigs under hot conditions (Wettemann and Bazer 1985). Severe economic losses in productivity of livestock in the USA have been estimated to be a consequence of heat stress (St-Pierre et al. 2003). Similar effects are likely to occur more frequently with increasing summer temperatures in the Nordic countries. 


\subsubsection{Feed quality and feed security}

More variable weather and more extreme weather events are likely to result in more variable quantities and quality of crops such as cereals, roughages and protein crops, with the consequence of unstable feed prices both globally and locally. This has already occurred in recent years, with large fluctuations in grain prices as a result of droughts in wheat-producing regions.

In the Nordic countries, imported fodder is important, particularly in animal production based on monogastric species (Åby et al. 2014). Global warming and extreme meteorological events are expected to lead to a decrease in crop yields and agricultural productivity in southern countries, leading in turn to reduced availability and higher prices of grains for animal feed in the future. Hence, self-sufficiency in fodder production needs to be increased in the Nordic countries to ensure future food and feed security. This may involve the utilisation of less productive marginal land for fodder production and pastures, resulting in more extensive production systems with lower production levels than at present (Kantanen et al., in preparation). At the same time, total production needs to be increased due to human population growth in the Nordic countries, which is estimated to be about $20 \%$ by 2030 .

Climate change is expected to create opportunities for growing crops in the Nordic countries that do not currently thrive in the region. This may reinforce the current trend of maize cultivation in the Nordic countries. However, variable weather, and in some cases extremes in weather, may lead to insecurity of harvests and very variable feed quality, which will hamper any boost in the degree of self-sufficiency. Highly productive animals may be particularly vulnerable in this situation, as they require high-quality feed to perform according to their genetic ability. Increased use of marginal land for livestock production will also require animals that can produce under extensive conditions with low quality feed.

\subsubsection{Genotype-environment interaction}

The interaction of genotype with the environment is defined as different performance of the same genotypes in different environments. G x E may become increasingly important under climate change because the ability of animals to adapt to changes may prove to be different both between breeds and between individuals. Research on dairy cattle has shown genetic antagonism between traits recorded under normal conditions and heat stress conditions, both for fertility and for milk yield (Ravagno- 
lo et al. 2000a). There is some evidence of G x E for fertility traits with respect to an environmental index based mainly on temperature, rainfall and herd production levels in the UK (Strandberg et al. 2009). The same principle may apply to feed of different quality, for example, as discussed above. This implies that performance needs to be recorded under the same conditions as the actual production environment for selective breeding to be most efficient.

\subsection{Mitigation of and adaptation to climate change}

Adaptation is a relatively loosely defined concept. It generally refers to the process or changes in behaviour, physiology and structure of an organism to become better suited to an environment. Adaptation is thus a relative concept, and in the context of climate change refers to changes that make individuals better suited to the anticipated environment. Thus, adaptation does not exclude the possibility that additional changes could further increase suitability to a given environment.

\subsubsection{Feed security}

At present, Nordic livestock production relies significantly on imported feed resources. In 2011, the proportion of imported carbohydrates, fat and protein for the Norwegian concentrate industry was $22 \%, 48 \%$ and $60 \%$, respectively (reviewed by Åby et al. 2014). Imports are likely to increase in the future as a consequence of higher fat and protein content in concentrates in order to meet the higher energy demands for increased production. Reliance on feed imports makes Nordic food production vulnerable to climatic, political, demographic and other changes in other parts of the world.

Low self-sufficiency of feed resources in the developed world results in undesirable usage of arable land at the global level. Globally important feed resources, such as soybeans, are mainly produced on land area that would be suitable for human food production for a growing local population. Additionally, to meet the increasing demand for high-quality protein feed resources, more arable land is needed, resulting in the cutting down of forests with a high capacity for retaining $\mathrm{CO}_{2}$, thereby counteracting mitigation policies.

Improved food security can be achieved through increased selfsufficiency of feed ingredients for livestock production, in particular 
concentrates. This calls for comprehensive changes in feed production in the Nordic countries.

To increase the self-sufficiency of carbohydrates for livestock feed, more arable land has to be used for cereal production directed towards production of concentrates. This boils down to whether such changes in arable land use are possible in a particular country. Alternative protein (e.g. peas, rapeseed) and fat sources should be investigated, in addition to those currently available. This is not a question of land use only (from human consumption to feed production), as there is a need to adopt and develop potentially novel varieties of cultivated plants or alternative feed resources whose exploitation may require further technological development.

An alternative or a supplement to current feeding strategies would be to allow more extensive production systems with increased use of roughage or alternative feed sources such as by-products of agriculture or other waste products. This would be accompanied by a trade-off in the form of lower production, but could be counteracted by selective breeding and optimal utilisation of animal genetic resources.

Utilisation of novel feed ingredients, including waste products, will require technological development that should concentrate on sideproducts of plants already in production or new plant varieties cultivated with very low input of mineral fertilisers, as production of fertilisers requires a lot of energy (Åby et al. 2013).

Modelling of production systems in a changing climate should include different scenarios of feed self-sufficiency. Additionally, "feed flexibility" of livestock, indicated by G x E (breed by feed) interactions should be investigated.

Genetically modified organisms (GMOs) comprise a steadily increasing share of the world's crops. Nordic countries have varying policies on GMO feedstuffs. Norway does not permit GMO feedstuffs for use in animal feeds. In Sweden and Finland, the use of GMO soy is minor, whereas in Denmark, approximately $80 \%$ of the soy used for animal feeds is GMO (Åby et al. 2014). A Nordic GMO policy that differs from policies in other (feed-producing) parts of the world may be hindered by a low degree of self-sufficiency with respect to feed production.

The price of protein and energy feed resources is likely to increase in the future. Additionally, any global climate, food, water, energy or land use crisis could hamper the import of food and feed ingredients if exporting countries prioritise their own needs. Improved food safety will result in increased sustainability and predictability of livestock production based on a stable supply of feed ingredients. Additionally, the cli- 
mate-smart agriculture advocated here, with appurtenant technological developments, is expected to have positive socio-economic effects by creating jobs that support rural livelihoods (FAO 2013).

\subsubsection{Modelling livestock production systems}

Life cycle assessment (LCA) models are increasingly being used for comparing the effects of intervention strategies in cattle production and comparing conventional and organic systems (deBoer 2003, Kristensen et al. 2011, Guerci et al. 2013). LCA models should ideally include all relevant steps in the production chain, and they should be able to assess effects of changes to the components in the chain, such as changes in feeding strategies or use of altered and improved livestock genotypes. A study comparing US dairy production in 1944 and 2007 (Capper et al. 2009) demonstrates how numerous factors acting together result in more efficient production with less methane emission per kg milk. Although that report was not a strict LCA, the principle of including as many items as possible opens for a more holistic evaluation. LCA has been applied to GHG emission studies (e.g. Kristensen et al. 2011), but consideration of genetic variation in key traits, which was for brevity omitted, should be included. Consequently, modelling tools need to be improved to include genetics as well as other animal-related features, such as fertility, production and functional traits.

The LCA approach is also relevant when considering the interaction between livestock production and plant crop production at the farm or local level. For instance, the available genotypes of dairy animals may affect the choice between intensive feeding and grazing pastures. Or, the other way around, using pastures will require cows with a suitable genotype. Such dependencies will extend to changes in the management system, and eventually affect the output product. The impact could even include effects on biodiversity in the production environments.

As an example, replacing dual purpose red cattle with Jersey cows has numerous consequences: milk with higher fat and lower protein content is produced and less meat is obtained per slaughtered cow. While less feed is needed to maintain the smaller cows and raise young stock, male calves have so little economic value for meat production that they are considered waste.

LCA will be an effective tool for estimating the total consequences of such a breed replacement because it takes into consideration all aspects of the life cycle, and all inputs and outputs from the production chain. Simi- 
larly, LCA will be a useful tool for estimating the consequences of genetic selection applied to a given breed and subsequent changes in production.

\subsubsection{Changes in the production system}

In some situations, mitigation of GHG emissions is possible by changing the production system. For instance, in the case of cattle production, an increasing level of specialisation is taking place through specialised dairy and beef breeds. However, beef production by specialised beef breeds in particular is generating large GHG emissions relative to the amount of human edible food produced. The main problem is that suckler cows consume large amounts of feed and are producing only one calf per year and no milk for human consumption. In contrast, dual-purpose breeds, which combine milk and beef production, are producing more human food for the same GHG emissions. However, this change conflicts with the aforementioned strategy of adaptation to climate changes by utilising more marginal pasture land, since beef cattle can utilise more marginal pastures than dairy and dual-purpose cattle. Another change to production systems that may be envisaged is the replacement of beef production with sheep and horse meat production, both of which are more efficient in terms of GHG emissions. But this will also require increased consumption of sheep and horse meat relative to beef. Whether these and other potential changes to production systems will result in significant GHG emission reductions requires further investigation.

\subsubsection{Intensive vs. extensive production systems}

Technological advances to reduce GHG emissions are often more easily implemented in intensive production systems because the animals are housed indoors in confined areas and there are more opportunities for handling both manure and gas emissions. Additionally, the high costs of implementing new technologies in an intensive high-input/high-output system can be justified, whereas a similar increase in costs will turn a low-input/low-output system into an unprofitable enterprise. Breeding schemes can be employed to reduce GHG emissions in both intensive and extensive production systems, although the recording of GHG emissions may be easier in intensive systems.

Intensive production systems result in higher total production levels, meeting the general increased demand for food due to increased human population in the Nordic countries, and higher feed efficiency (based on higher quality feeds) in intensive production systems results in lower 
GHG emissions per kg of product compared to extensive systems. On the other hand, in extensive grazing systems the sequestration of GHG may balance the generally higher GHG emissions. Taking all these aspects into consideration, it appears that an efficient combination of intensive and extensive production systems, combined with an increased use of local (sometimes marginal) land, is the most promising plan of action in order to meet the increased demand for food.

\subsubsection{Carbon sequestration and grazing}

Carbon sequestration in soils has potential to mitigate climate change by reversing the current trends of reduced carbon in cropland (and correspondingly more $\mathrm{CO}_{2}$ in the atmosphere). Converting arable land to grazing land is one of the changes that would contribute to increased carbon storage (Smith 2004). This being said, the conversion of arable land into grassland may bring about a global net loss in cropland. This in turn may increase the deforestation of tropical areas as more land is needed for growing crops. Such a shift in land use would have a negative net effect on mitigation since reforestation has the largest potential for terrestrial carbon sequestration, followed by agricultural soils and then pastureland activities (Thomson et al. 2008). Grassland carbon sequestration has strong potential to partially mitigate the GHG balance of ruminant production systems by net carbon storage in soils (Soussana et al. 2010). Effects are highly dependent on management strategies, so more knowledge is needed to balance increased carbon storage with increased GHG production from the grazing ruminants, e.g. effects of species and breeds.

Cattle production has been identified as one of the causes of climate change because of cows emitting methane, which is a GHG with a warming potential about 25 times that of $\mathrm{CO}_{2}$. Consequently, a number of strategies that could reduce methane emissions have been the focus of research. These strategies include choice of feedstuff or diet composition, feed additives and genetic strategies for breeding animals with lower emissions. When emissions were calculated per $\mathrm{kg}$ of product, high-producing dairy cows were shown to have the lowest emission rates (Capper et al. 2009). Furthermore, high-producing cows are also more efficient at converting animal feed into human edible food (e.g. Capper et al. 2009), basically because maintenance costs are diluted over a higher production. Consequently, and fortunately, dairy farmers will seek to raise efficient cows that concomitantly have lower methane emissions, so there appears to be no conflict of interest. However, it may 
not be so simple, and objections to this claim have been raised by Gerber et al. (2011). This underlines the need to perform LCAs for a thorough evaluation of consequences. Genetic selection for more productive dairy cows is already on-going by selection for higher yields. However, dedicated selection for better feed utilisation and reduced methane emission are hampered by a lack of inexpensive data-recording routines. Suggested prototype methods for GHG measurements on individual cows are currently being investigated, but are only available on a few experimental farms thus far.

Previously, pasture was the main feed source for all cattle, at least during the grazing season. However, dairy cattle are increasingly being kept indoors all year round in highly intensive systems, e.g. in Denmark, Holland and Germany, whereas in other regions grazing still prevails and is expected to continue (e.g. Ireland, New Zealand). Thus, strategies for mitigation should address both systems, but possibilities are dependent on the individual system. Intensive systems are ideal for applying a range of control technologies, such as new automated data-recording systems and decision support tools, and technologies that reduce methane emissions from animals, farms and/or manure. For extensive systems, genetic selection for improved efficiency and reduced methane emissions is a more feasible option. There should be no conflict of interest in using the same genetic material in both systems because the intensive systems would similarly benefit from having more efficient cows. This assumes that efficiency is defined similarly in both systems; an assumption that needs to be verified experimentally.

Grazing of marginal areas would generally be more feasible in a warmer climate that allows for longer grazing seasons and/or higher feed production. The exception to this is reindeer farming. Global warming may increase the frequency of deep or hard snow in reindeer ranges due to increased precipitation and more frequent mild periods in winter. Potential benefits from increased plant productivity due to global warming will be counteracted by shifts in the distribution of preferred lichen forage, reduction of the area of suitable winter ranges and generally reduced forage accessibility in winter (Heggberget et al. 2010). Making use of increased possibilities for grazing requires the use of species and breeds suited to local conditions. A shift from beef cattle to sheep production would be beneficial with respect to lowering GHG emissions from livestock production, and a lighter species may also be better suited to relatively wet pasture areas in many cases. 


\subsection{References}

Capper, J.L., Cady, R.A. and Bauman, D.E., 2009. The environmental impact of dairy production: 1944 compared with 2007. Journal of Animal Science, 87, 2160-2167.

FAO, 2013. Climate-smart agriculture sourcebook. Available at: www.fao.org/climatechange/climatesmart.

de Boer, I.J.M., 2003. Environmental impact assessment of conventional and organic milk production. Livestock Production Science, 80, 69-77.

Guerci M., Knudsen, M.T., Bava, L., Zucali, M., Schönbach, P. and Kristensen, T., 2013. Parameters affecting the environmental impact of a range of dairy farming systems in Denmark, Germany and Italy. Journal of Cleaner Production, 54, 133-141.

Heggberget T.M., Gaare, E. and Ball, J.P., 2010. Reindeer (Rangifer tarandus) and climate change: Importance of winter forage. Rangifer, 22(1), 13-31.

Hoffman, I., 2010. Climate change and the characterization, breeding and conservation of animal genetic resources. Animal Genetics, 41 (Suppl. 1), 32-46.

Kantanen, J., Løvendahl, P., Strandberg, E., Eythorsdottir, E., Li, M.-H., KettunenPraebel, A. and Meuwissen, T.H.E., 2014. Changes in agro-ecological circumstances and the role of farm animal genetic resources in mitigation and adaptation issues in the Nordic livestock production (manuscript in preparation).

Kristensen, T., Mogensen, L., Knudsen, M.T. and Hermansen, J.E., 2011. Effect of production system and farming strategy on greenhouse gas emissions from commercial dairy farms in a life cycle approach. Livestock Science, 140, 136-148.

Nardone, A., Ronchi, B., Lacetera, N. and Bernabucci, U., 2006. Climatic effects on productive traits in livestock. Veterinary Research Communications, 30 (Suppl. 1), 75-81.

Purse, B.V., Mellor, P.S., Rogers, D.J., Samuel, A.R., Mertens, P.P. and Baylis M., 2005. Climate change and the recent emergence of bluetongue in Europe. Nature Reviews Microbiology, 3(2), 171-81.

Ravagnolo, O., Misztal, I. and Hoogenboom, G., 2000. Genetic component of heat stress in dairy cattle, development of heat index function. Journal of Dairy Science, 83, 2120-2125.

Smith, P., 2004. Carbon sequestration in croplands: the potential in Europe and the global context. European Journal of Agronomy, 20(3), 229-236.

Soussana, J.F., Tallec, T. and Blanfort, V., 2010. Mitigating the greenhouse gas balance of ruminant production systems through carbon sequestration in grasslands. Animal, 4(3), 334-350.

St-Pierre, N.R., Cobanov, B. and Schnitkey, G., 2003. Economic Losses from Heat Stress by US Livestock Industries. Journal of Dairy Science, 86 (Suppl.), E52-E77.

Strandberg, E., Brotherstone, S., Wall, E. and Coffey, M., 2009. Genotype by environment interaction for first-lactation female fertility traits in UK dairy cattle. Journal of Dairy Science, 92, 3437-3446.

Thomson, A.M., Izaurralde, R.C., Smith, S.J. and Clarke, L.E., 2008. Integrated estimates of global terrestrial carbon sequestration. Global Environmental Change - Human and Policy Dimensions, 18(1), 192-203.

Wettemann, R.P. and Bazer, F.W., 1985. Influence of environmental temperature on prolificacy in pigs. Journal of Reproduction and Fertility, 33, 199-208.

Åby, B.A., Kantanen, J. and Meuwissen, T., 2014. Future trends in livestock production in the Nordic countries with a changing climate and human population growth. (Submitted to Acta Agriculturae Scandinavica.) 



\section{Forestry}

\subsection{Introduction}

The Nordic region has over 61 million ha of forests, which constitutes just under one-third of all forests in Europe excluding the Russian Federation. Finland, Sweden and Norway together are home to practically all of the forests in the region, as shown in Figure 7.1.

Figure 7.1: Distribution of forests in the Nordic region

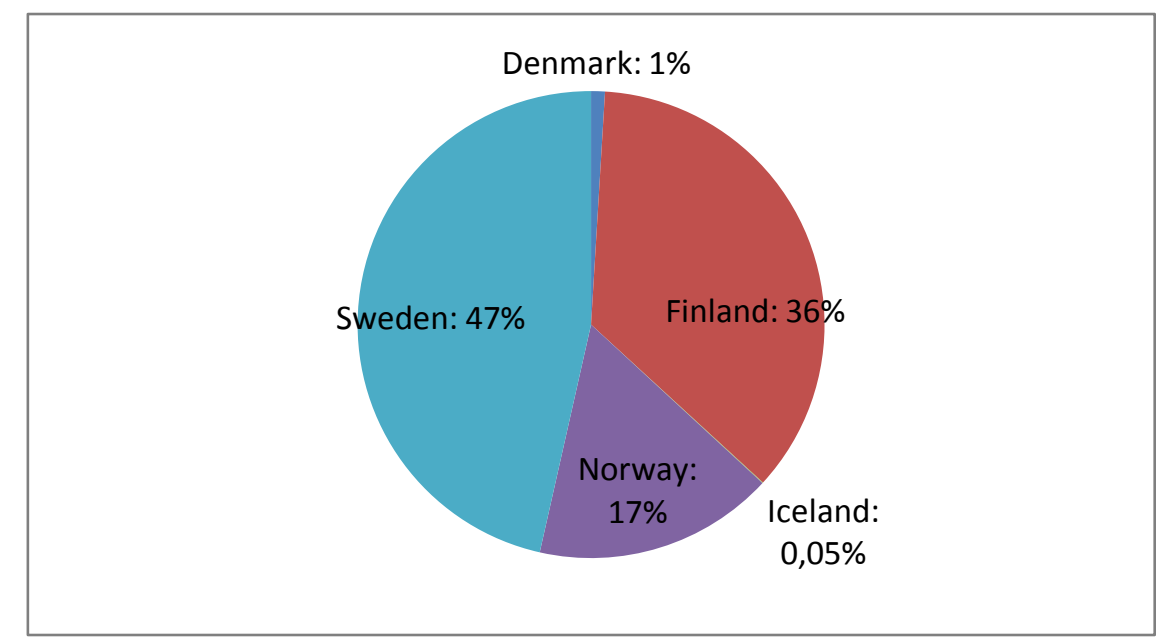

Source: Indufor (2013).

The forests in these three countries, and thus the entire Nordic region, are mainly boreal (see Figure 7.2). Forests in Denmark and some forests in the southern parts of Norway and Sweden fall under the temperate category. 
Figure 7.2: Distribution of boreal forests in the Nordic region

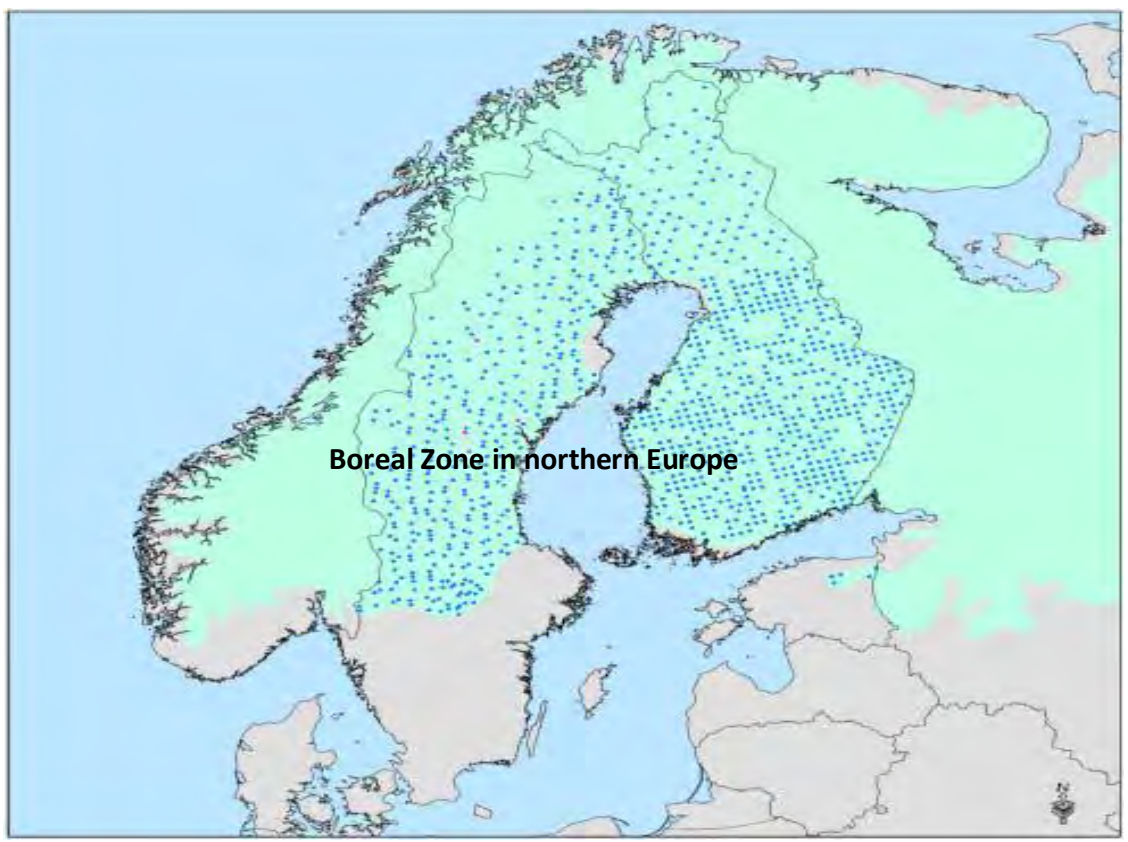

Source: Adapted from Linder et al. (2008).

Climate change is likely to entail both opportunities and risks with regard to the Nordic forests. Against this background, this chapter discusses observed and likely changes and risks induced by climate change to forests in the Nordic countries. The chapter also discusses climate change adaptation of forests and potential mitigation options in the Nordic countries.

\subsection{Observed changes in and impacts of climate change on forest ecosystems}

\subsubsection{Forest phenology, growing season and growth}

It has been observed that the increase in temperature has caused bud burst and flowering in boreal forests to occur earlier than before, i.e. advance in spring onset. Linkosalo et al. (2009) showed that the bud burst in boreal trees has advanced at an average rate of 0.3-1.1 days per decade over the past 160 years. A number of other studies (e.g. Nordli et al. 2008, Pudas et al. 2008) focusing on phenological shifts in recent decades reported a faster rate of advancement in spring onset of 2-14 days per decade in boreal forests. The impacts of climate change on au- 
tumn phenology of boreal forests are a bit more uncertain than that of spring phenology. Nevertheless, studies (e.g. Jeong et al. 2011) suggest that there has been delay in leaf colouring and abscission in boreal forests over the past few decades. The effects of climate change on the spring and autumn phenology of temperate forests is similar to that of boreal forests (Richardson et al. 2013).

The advance in spring onset and delay in autumn phenology sequencing due to the temperature rise induced by climate change in the forests of the Nordic region increase the length of the growing season. Kauserud et al. (2008) reported that the growing season in boreal forests has actually increased by 11 days since 1960, while Peñuelas et al. (2009) estimated an average increase of 3-4 days per decade for the coming decades. For temperate forests, the increase in the growing season due to the temperature rise is estimated to be 2.1-4.2 days per decade over the past few decades (Menzer et al. 2008, Jeong et al. 2008).

The increase in temperature also enhances the decomposition of soil organic matter, which in turn may increase the supply of nitrogen in the forest ecosystem. This, together with the prolonging of the growing season, enhances forest growth, timber yield and carbon sequestration in the Nordic region. For example, in Finland forest growth may increase by $44 \%$ by the end of the current century due to the prolonging of the growing season (Kellomäki et al. 2008). The availability of more $\mathrm{CO}_{2}$ under climate change will not affect phenology itself, but rather contribute to enhancing the growth of and carbon sequestration in forests.

\subsubsection{National forest inventories: biomass production and growing stock}

Between 1925 and 2010, the general trend in the growth of forest biomass stock, ${ }^{3}$ and thus the forest growing stock in Sweden, Finland and Norway, was positive. ${ }^{4}$ In Denmark and Iceland, forest biomass stock increased steadily between 1990 and 2010 (Figure 7.3). This is largely the result of improved forest management over decades in the Nordic countries. The drain on forest growing stock and biomass due to harvesting and natural decomposition has been lower than the growth of the stock, thus the net annual increment of forest growing stock has

\footnotetext{
${ }^{3}$ Forest biomass includes above- and below-ground live biomass and deadwood.

${ }^{4}$ Sweden, Finland and Norway started a forest inventory as far back as the mid-1920s, while Denmark and Iceland have only recently started an inventory.
} 
been positive during past decades in all five countries (Figure 7.4). Moreover, in Sweden, Norway, Denmark and Iceland, the total forest cover has increased over the past two decades, which has also contributed to an increase in forest increment and biomass stock (FAO FRA 2010). Although forest cover in Finland decreased slightly during that period due to construction and building activities, the annual increment in biomass and growing stock was far greater than the annual harvest, and thus the net annual increment in biomass stock was positive.

Figure 7.3: Trends in forest biomass in the Nordic countries

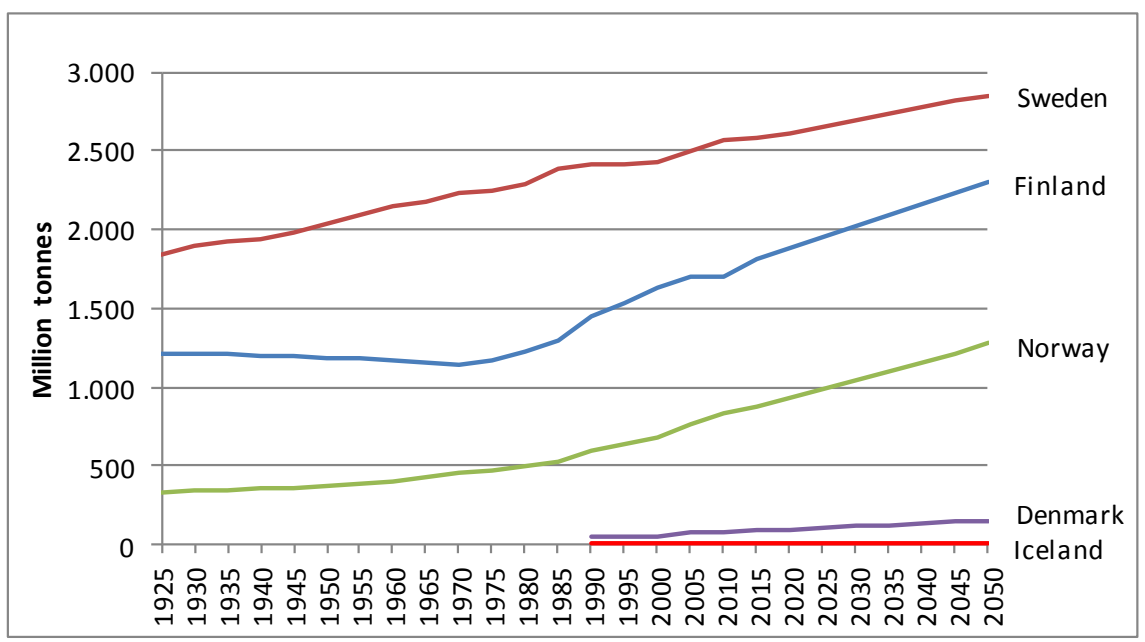

Source: Indufor (2013).

Figure 7.4: General trend in forest growing stock in the Nordic countries

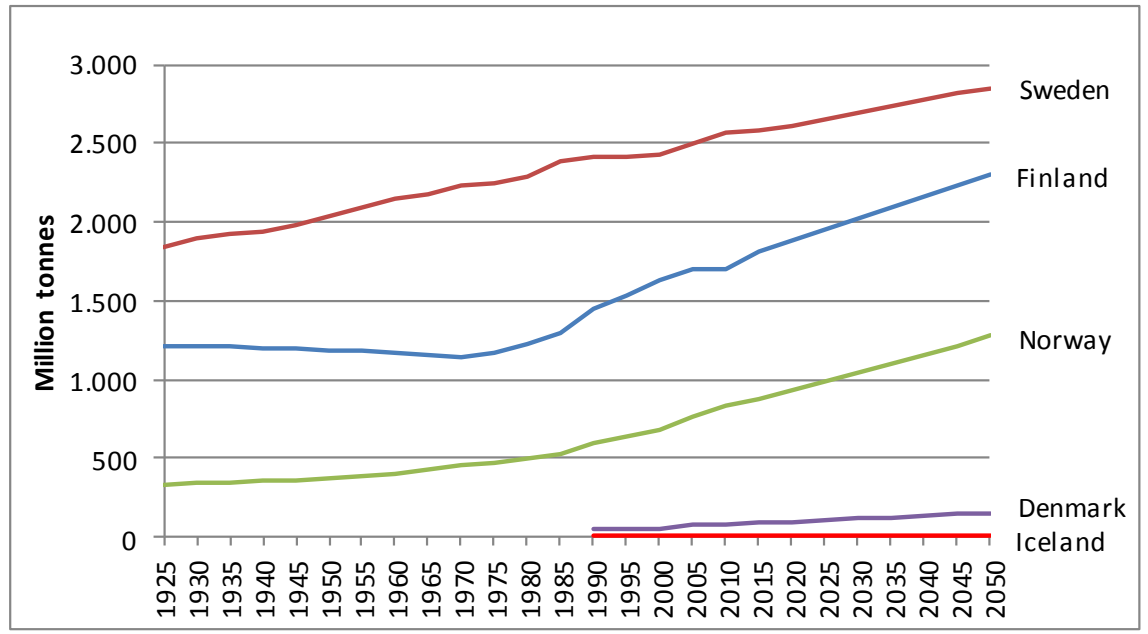

Source: Adapted from FAO FRA (2010). 
In coming decades, the climate change-induced temperature rise may boost forest growth in the Nordic region, and it is anticipated that improvements in forest management in the region will continue. As a result, the growth of forest biomass is expected to exceed harvest and other losses, and thus the standing forest biomass stock in all the Nordic countries is likely to increase steadily in the coming decades as well (Figure 7.3). Faster growth due to climate change may affect the quality of the timber produced in the Nordic forests in the future; however, the exact nature of the effect is highly uncertain.

\subsubsection{Carbon sequestration in forests}

Trees absorb atmospheric carbon (i.e. carbon removal) and use it in photosynthesis. The carbon is released when trees are harvested and burned as well as through the decomposition of dead tree parts. A negative net removal of atmospheric $\mathrm{CO}_{2}$ by forests means that the forests sequestrate carbon and are a carbon sink, while a positive net removal means that the emissions, and thus the forests, are a carbon source.

Between 1990 and 2010, the forests in all the Nordic countries except Denmark 5 were carbon sinks. The rate of forest carbon sequestration in the Nordic countries, as shown in Figure 7.5, has either gradually increased or generally followed a constant path. This mirrors the fact that the rate of positive net annual growth has increased in some Nordic countries and remained constant in others because the growth in forest biomass stock has exceeded the drain by harvest. As can be seen in Figure 7.5, the carbon sequestration rate in Sweden, Finland and Norway has clearly been higher than in Denmark and Iceland. This is due to the fact that the forested area in the first three countries is much bigger than that in the latter two countries.

${ }^{5}$ Denmark's forests were a carbon source through the first half of the 2000s. 
Figure 7.5: Carbon sequestration by the Nordic forests

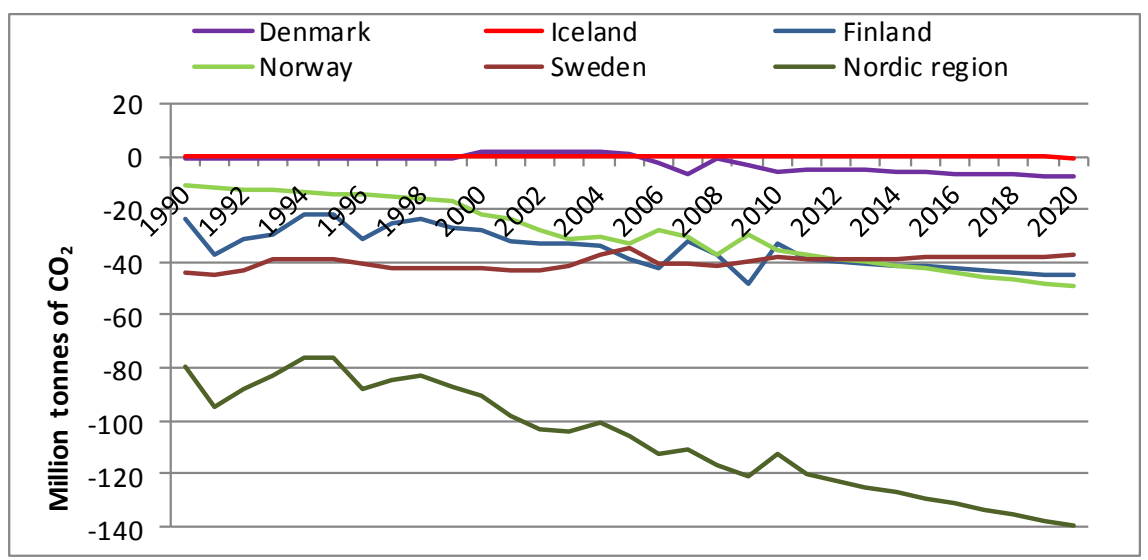

In the future, due to the potential boost in forest growth induced by climate change and the practice of sustainable forest management, the gap between the growth and drain of forest growing stock and biomass from forests is expected to widen. Thus, the rate of positive net growth in biomass is likely to increase. As a result, the carbon sequestration rate (i.e. negative net removal of $\mathrm{CO}_{2}$ ) is expected to increase steadily in the Nordic forests in the future (Figure 7.5).

\subsubsection{Utilisation of wood and avoiding carbon emissions}

Wood is an essential primary material for construction, furnishings, printing, packaging and energy production. It is considered more environmentally friendly than competing materials such as plastic and steel, especially when the entire product life cycle is taken into account. The displacement factor ${ }^{6}$ of wood is about 2 (Sathre and 0'Connor 2010), which implies that the use of $1 \mathrm{~m}^{3}$ of wood products as a substitute for products made of competing materials results in the reduction of approximately two tonnes of carbon emissions (see Figure 7.5)

\footnotetext{
${ }^{6}$ A displacement factor refers to the efficiency with which the use of biomass reduces net GHG emissions. It quantifies the amount of emission reduction achieved per unit of wood use. A higher displacement factor indicates a higher level of GHG emission reduction; a negative displacement factor indicates a higher level of emissions from using the wood product.
} 
Figure 7.6: Carbon emissions reduction through wood use
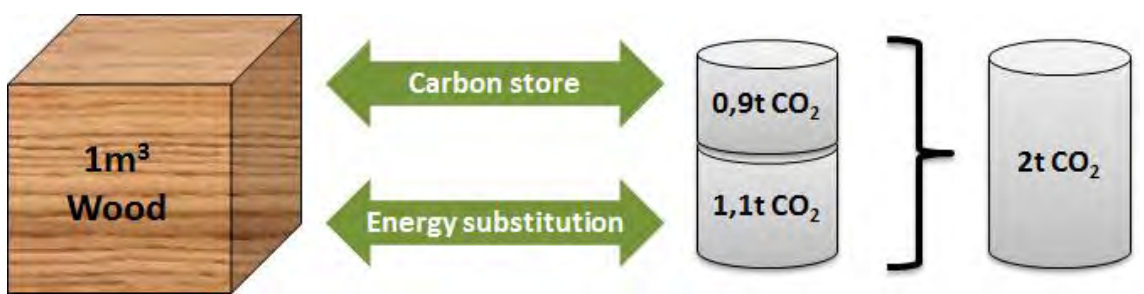

Source: Indufor (2013)

As Figure 7.6 suggests, emissions reduction through the use of wood is a result of both storage and substitution. Wood products provide a physical storage of carbon that would otherwise be released into the atmosphere and act as a GHG. The longer the product life cycle, the longer the carbon storage. Therefore, the carbon storage benefits of products such as solid wood furniture and wood used in construction are higher than those of products with a relatively short life cycle, such as paper products. In addition, in some cases, wood products are used for landfill at the end of their life cycle, instead of being recycled or burned as biofuel. The decay of wood used for such purposes may be so slow that the landfill can be considered semi-permanent carbon storage.

The use of wood products can also have a substitution effect on carbon emissions. This is because the manufacture of wood products usually consumes relatively less fossil energy than the manufacture of products from competing materials such as cement, concrete and plastic.

To enhance the carbon benefits of wood products, initiatives have already been launched to increase the use of wood in Europe. For example, Sweden has recently implemented the Trästad 2012 project that aims to change the country's architectural methods by developing an architecture, technology and business model for timber structures, ultimately promoting the use of wood in construction. France passed a decree increasing the use of wood in building in 2010 .

\subsubsection{Bioenergy}

As members of the European Union (EU), Denmark, Finland and Sweden are obligated to adopt the EU target of $20 \%$ final energy consumption from renewable energy by 2020, as set out in the EU Renewable Energy Sources (RES) Directive. Although Norway and Iceland are not EU member states, they must comply with the directive pursuant to commitments under the European Economic Area (EEA) Agreement. The di- 
rective has already become a strong driving force in promoting the use of wood for energy in Europe.

Figure 7.7: Use of woody biomass for energy production in the Nordic countries

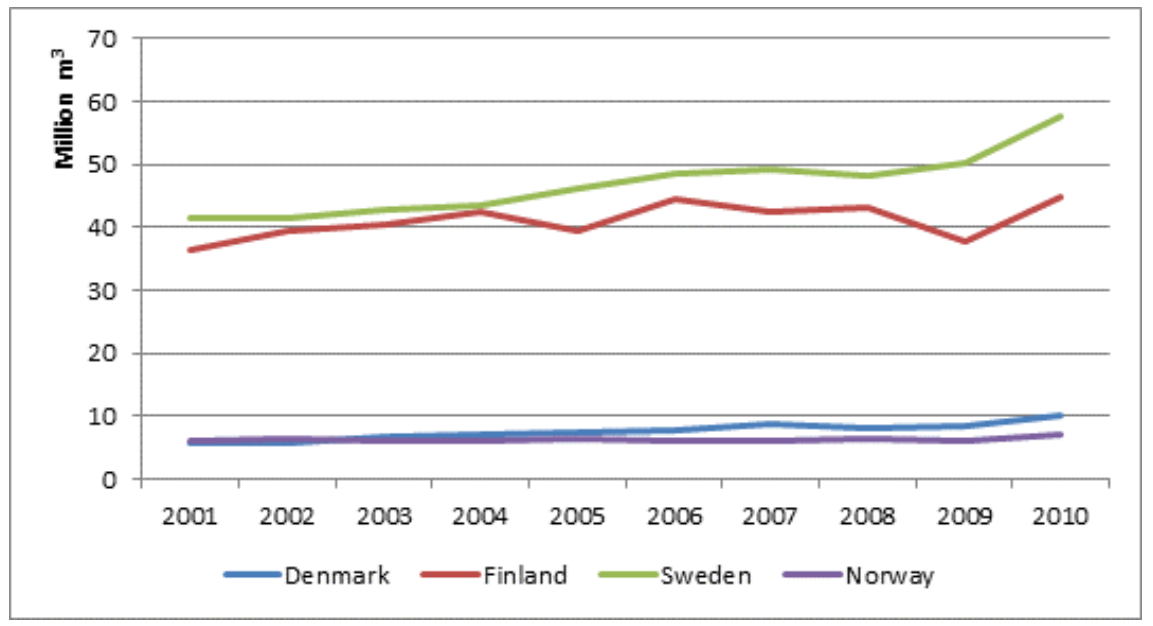

Source: Adapted from Eurostat 2013.

The use of wood and wood waste for energy production in the Nordic countries has followed an increasing trend over the past decade. The figure also illustrates the impact of adopting policies promoting renewable energy. Sweden and Finland clearly use more wood for energy than the other Nordic countries. A lion's share of the wood energy in these countries is produced using black liquor, bark and sawmilling byproducts as fuel. The use of forestry residues from e.g. thinning and harvesting, and of wood pellets, has also been increasing in recent years. Moreover, Finland has implemented the KEMERA subsidy scheme that encourages the harvesting of young stands of trees for energy production purposes (Barua and Bonilha 2013). It should also be noted that both Sweden and Finland have a longstanding tradition of using firewood in energy production in small-sized dwellings. In Denmark, the level of wood used for energy production was higher than in Norway in the second half of the past decade. This is mainly due to an increase in wood pellet consumption (in part imported). In Iceland, use of wood for energy production has been marginal. 


\subsubsection{Biodiversity}

Forests are a key component of landscape diversity in Finland, Norway and Sweden as these countries are abundantly forested. Forests are an important feature of the landscape in Denmark as well. Although forests are not the most common feature of the landscape of Iceland, they used to cover $25 \%$ of the land before human colonisation.

The forests in the Nordic region are home to about 25000 floral and faunal species. ${ }^{7}$ These constitute approximately half of all species found in the region, including colourful wildlife such as moose (Alces alces) and brown bear (Ursus arctos). The Nordic forest species diversity also consists of 54 tree species (Stokland et al. 2003). The most common and most commercially exploited trees are, however, limited to just a few species. Norway spruce (Picea abies), scots pine (Pinus sylvestris), silver birch (Betula pendula) and downy birch (B. pubescens) are the most common and commercially important tree species in Finland, Norway and Sweden. In fact, these four species constitute over $90 \%$ of the volume and annual increment of the growing stock in Finland and Sweden (Statistics Finland 2012, Environmental Protection Agency (EPA) of Sweden 2012). In Denmark, beech and oak are also commonly found (NFF 2013).

The species distribution in the Nordic forests may change under future climate change. According to the most extreme warming scenarios, the climate in northern parts of Sweden, Finland and Norway may start to resemble that of the southern parts, while conditions in the southern parts may resemble those of central Europe by the end of this century (e.g. Kinnunen et al. 2013). As a result, broadleaved deciduous trees in the boreal forests of the Nordic region may expand their potential distribution ranges, which could increase tree species diversity and functional diversity. In the region's temperate forests, a shift in the natural species composition from coniferous dominated forests to broadleaved species may occur. Biotic and abiotic factors such as insects, pathogens, fire and wind are also likely to affect the structure and composition of forests in the Nordic region under climate change (see also Section 7.3.2).

Intensive forest management as currently practised in the Nordic region will, however, strongly influence the transitional forest structure by maintaining economically important species outside their natural range

\footnotetext{
${ }^{7}$ As reported by the Centre of Advanced Research on Environmental Services on Nordic forest ecosystems. Available at: http://www.nordicforestry-cares.org/index.htm.
} 
(e.g. Norway spruce) or by supporting the regeneration of new target species (Linder et al. 2008). Strict forest conservation may not be a solution either, although it is usually beneficial for forest biodiversity conservation. Forests under such conservation become unavailable for harvesting, thereby reducing the timber supply both in the short and the long term. An ideal solution would incorporate forest conservation measures within forest management to benefit biodiversity without reducing the timber supply.

\subsection{Climate change-induced risks to forests}

\subsubsection{Abiotic risks}

In Northern Europe, the temperature is projected to rise in the future due to climate change, and the mean annual precipitation is projected to increase as well, with most of the increase concentrated in the winter months (see Chapter 1). While higher temperature enhances evaporation and thus the potential for forest fires, an increase in precipitation does the opposite. Nevertheless, studies (e.g. Wotton et al. 2010, Kilpeläinen et al. 2010) have concluded that forest fire risk will increase in the Nordic countries with the changing climate. For example, in Finland, there was an average of 60-100 forest fire warning days per year in the late 20th century. This is projected to rise by $30 \%$ in the coming decades, thereby increasing the actual number of forest fire incidents by $20 \%$. In Russia and Canada, burned forest area has increased considerably in the past two decades (cf. Kirilenko and Sedjo 2007).

Due to climate change, the snow season will probably become shorter (Räisänen and Eklund 2012), while the amount of snowfall is likely to increase during the mid-winter months in Northern Europe. This could increase the risk of snow-induced forest damage. Increased precipitation during the winter months is likely to increase soil waterlogging and the occurrence of winter flooding, which could in turn increase the susceptibility of forest to windthrow as the waterlogging loosens the support of the roots in soil (Linder et al. 2008). There are some indications of this in the recent past. In Sweden, Hurricane Gudrun, which had a maximum gust speed of $43 \mathrm{~m} / \mathrm{s}$, damaged more than 60 million $\mathrm{m}^{3}$ of timber in 2005 .

The risk of forest damage due to wind and storms is expected to increase in the future. More waterlogging and winter flooding and a shorter frozen soil (i.e. soil frost) period will pave the way to greater damage due to wind and storms. For example, the duration of soil frost is ex- 
pected to decrease from 4-5 months to 2-3 months in southern Finland (Kellomäki et al. 2010), thereby increasing the susceptibility of forests to wind-induced damage, particularly uprooting (Peltola et al. 2010). The shortening of the period of frozen soils and snow cover is also likely to adversely affect forest management operations, e.g. by limiting the accessibility of forests in wet organic soils or decreasing the possibilities to use heavy machinery on slopes (Linder et al. 2008).

\subsubsection{Biotic risks}

Outbreaks of pests and disease are major sources of natural disturbance to forests. Such outbreaks can cause defoliation, growth loss, timber damage and even massive forest dieback. For example, about 14 million ha of forests was adversely affected by insect attack in Canada between 1998 and 2002. Climate change enhances the risk of such forest damage (cf. Kirilenko and Sedjo 2007). It may actually alter the physiology and possibly weaken the defence mechanisms of trees in boreal forests, making them increasingly susceptible to insect and pathogen attack (e.g. Marini et al. 2010). It may also dramatically shift or extend the natural habitats of insects and pathogens, damaging vast forest areas. There is already evidence that forest insects such as mountain pine beetles shift their habitat in Canada when the temperature rises. Likewise, the European spruce bark beetle (Ips typographus), which is commonly univoltine in southern Sweden, may produce a second generation in the area at an annual average temperature rise as low as $2-3^{\circ} \mathrm{C}$.

A rise in winter temperature in the boreal zone, which is likely under climate change, can shift habitats further north and cause outbreaks of defoliating insects, such as European pine sawfly (Neodiprion sertifer) and autumnal moth (Epirrita autumnata), because their egg survival rate will increase. Moreover, gypsy moth (Lymantria dispar) and nun moth (Lymantria monacha) may expand their habitats northwards by 500$700 \mathrm{~km}$, causing outbreaks in northern deciduous forests in particular. The higher probability of forest defoliation will increase the risk of outbreaks of secondary pest insects dependent upon weakened host trees, such as the common pine shoot beetle (Tomicus piniperda). Moreover, Norway spruce forests are likely to be increasingly prone to large-scale infestation by the European spruce bark beetle (Ips typographus), as rising winter and summer temperatures speed up beetle development and may allow a transition from univoltine to multivoltine populations. In addition, increasing incidence of storm events and high winds can make pine forests in Denmark, southern Norway and southern Sweden 
more susceptible to bark beetle (e.g. Tomicus piniperda, I. sexdentatus, I. acuminatus) attacks (Linder et al. 2008).

Pathogenic fungi such as Gremmeniella abietina cause disease in pine forests in southern Finland and northern Sweden, especially on sites with high humidity and cold air. Mild winters combined with high precipitation during summer are likely to increase the risk of such pathogen outbreaks. Moreover, longer growing seasons associated with higher temperature may increase the incidence of root and butt rot in Norway spruce caused by Heterobasidion parviporum and H. annosum (Linder et al. 2008).

\subsection{Adaptation to and mitigation of climate change in forests}

\subsubsection{Forestry measures to adapt to climate change}

Forestry adaptation measures comprise forest-based responses to the risks and opportunities accompanying climate change. These measures usually aim at minimising the adverse effects of climate change induced by biotic and abiotic disturbance agents and ensuring wood production and continuous flow of other ecosystem services. Forestry adaptation measures can be categorised into three different levels with different action areas and potential measures at each level, as illustrated in Tables 7.1-7.3.

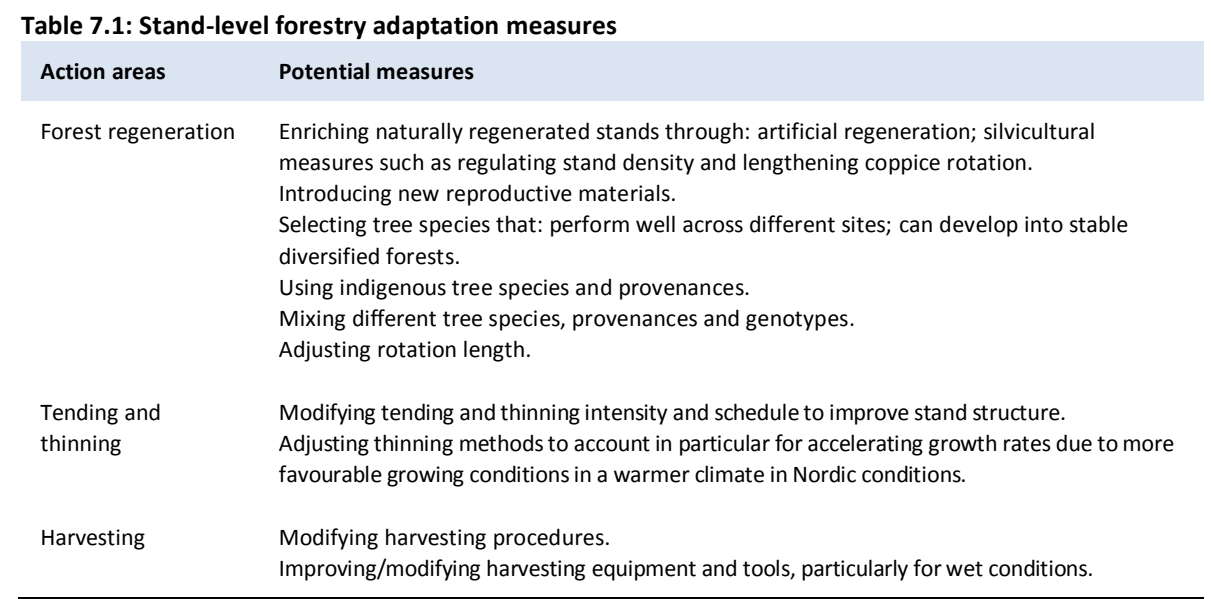

Source: Adapted from Linder et al. (2008), Carina and Keskitalo (2011). 
Table 7.2: Management-level forestry adaptation measures

$\begin{array}{ll}\text { Action areas } & \text { Potential measures } \\ \begin{array}{l}\text { Management } \\ \text { planning }\end{array} & \begin{array}{l}\text { Developing and applying innovative planning and decision support tools to deal with risk } \\ \text { and uncertainty. } \\ \text { Flexible adaptive planning, taking into account all conceivable scenarios and multiple options. } \\ \text { Increased cooperation between scientists, forest managers and stakeholders. }\end{array} \\ \text { Forest protection } & \begin{array}{l}\text { Establishing and sustaining forest ecosystems with highly diverse tree composition, age and } \\ \text { structure. } \\ \text { Replacing highly flammable species and regulating age-class distribution to minimise fire risk. } \\ \text { Avoiding heavy thinning to avoid snow and wind damage. } \\ \text { Using special thinning methods and suitable tree species to decrease the risk of erosion. } \\ \text { Adjusting afforestation activities to ensure water protection. } \\ \text { Reducing fuel accumulation in the forests to avoid forest fires. }\end{array}\end{array}$

Source: Adapted from Linder et al. (2008), Carina and Keskitalo (2011).

Table 7.3: Policy-level forestry adaptation measures

\begin{tabular}{|c|c|}
\hline Action areas & Potential measures \\
\hline $\begin{array}{l}\text { Infrastructure and } \\
\text { transport }\end{array}$ & $\begin{array}{l}\text { Excavating storage lakes and digging irrigation canals. } \\
\text { Deactivating drainage systems to restore the water regimes. } \\
\text { Developing appropriate road networks, especially in mountain areas, for the smooth } \\
\text { operation of small-scale management activities. } \\
\text { Reconstruction and regular maintenance of roads to minimise sediment runoff due to } \\
\text { increased precipitation and shortened frost period. } \\
\text { Improving forest road density. }\end{array}$ \\
\hline $\begin{array}{l}\text { Nurseries and } \\
\text { forest tree breeding }\end{array}$ & $\begin{array}{l}\text { Mixing seedlings from different seed stands already at the nursery stage. } \\
\text { Identifying seedlots to be mixed, based on provenance test results. } \\
\text { Monitoring genetic fingerprints using molecular markers and other biotechnological methods. }\end{array}$ \\
\hline $\begin{array}{l}\text { Adaptation integra- } \\
\text { tion in risk man- } \\
\text { agement and policy }\end{array}$ & $\begin{array}{l}\text { Reducing institutional and policy barriers to ensure prompt response to climate change. } \\
\text { Applying participatory development and evaluation of adaptation strategies involving } \\
\text { decision-makers, forest managers, stakeholders and experts. } \\
\text { Establishing forest reserves for investigation and monitoring of climate change impacts to } \\
\text { help with adaptation at the operation level. }\end{array}$ \\
\hline
\end{tabular}

Source: Adapted from Linder et al. (2008), Carina and Keskitalo (2011).

Apart from the above, regular monitoring of forest health, pests and diseases constitutes a crucial part of forest adaptation strategy. This not only helps to identify any new pests quickly, but also reduces the risk of any secondary damage agents becoming a large-scale threat.

\subsubsection{Climate change mitigation through forest management}

Climate change is likely to affect the carbon stock in forests by altering forest growth and soil processes. Thus, forest management practices are an important component of forest-based climate change mitigation strategy. The limited availability of nitrogen acts as a limiting factor for the growth of Nordic forests (e.g. Kellomäki et al. 1997), therefore nitrogen 
fertilisation is considered an effective silvicultural practice to enhance forest growth and increase carbon sequestration, particularly in less fertile sites (Norden 2013, Hyvönen et al. 2007). In the 1960s and 1970s, fertilisation played an important role in Finland in enhancing timber production (Kukkola and Nöjd 2000). In the southern part of Scandinavia, atmospheric nitrogen deposition is elevated and the supply is sufficient or sometimes in excess of what is needed. Here, the addition of other nutrients to increase carbon sequestration in biomass may be considered.

Silvicultural practices such as cleaning make more space and nutrients available for the remaining saplings or trees in young stands, and thus increase carbon sequestration in the forests in the long term. Likewise, increasing thinning thresholds may enhance biomass production and carbon stock, especially in boreal forests (e.g. Alam et al. 2012). Increasing the rotation length also has a similar effect (e.g. Ericsson 2003). Long rotations, on the other hand, increase the risk of biotic and abiotic damage. Management of forest landscapes initially dominated by young stands with longer rotation ensures higher wood productivity and thus higher carbon sequestration. It should be noted, however, that optimal rotation for maximising carbon sequestration often differs from economically optimal rotation. As a result, economic incentives such as payment for carbon sequestration are often needed to persuade forest owners to lengthen the rotation in order to maximise carbon sequestration. Multi-objective forest management, e.g. combining energy wood production and timber production, not only enhances higher carbon sequestration but also reduces $\mathrm{CO}_{2}$ emissions from forest management (Routa et al. 2012), thereby ensuring greater removal of atmospheric $\mathrm{CO}_{2}$. Similarly, combining several practices such as prolonged rotation, retention of old trees and dead wood, and keeping buffer zones around the wetlands have positive effects on biodiversity as well as on the carbon stock. Management practices should also strive to protect or possibly enhance carbon storage in soil organic matter, although more knowledge is needed to wisely combine this with goals to increase production in and biomass removal from forests. 


\subsection{References}

Alam, A., Kilpeläinen, A. and Kellomäki, S., 2012. Impacts of initial stand density and thinning regimes on energy wood production and management-related $\mathrm{CO}_{2}$ emissions in boreal ecosystems. European Journal of Forest Research, 131, 655-667.

Barua, S.K. and Bonilha, R., 2013. Economic competitiveness of forest biomass energy. In: S. Kellomöki, A. Kilpeläinen and A. Alam, eds. Management, Carbon Sequestration and Adaptation of Forest Bioenergy Production. New York, USA: Springer.

Carina, E. and Keskitalo, H., 2011. How can forest management adapt to climate change? Possibilities in different forestry systems. Forests, 2, 415-430.

Ericsson, E., 2003. Carbon accumulation and fossil fuel substitution during different rotation scenarios. Scandinavian Journal of Forest Research, 18, 269-278.

EuroStat., 2013. Available at: http://epp.eurostat.ec.europa.eu/portal/page/ portal/eurostat/home/.

FAO FRA, 2010. Global forest resource assessment. Rome, Italy.

Hyvönen, R., Persson, T., Andersson, S., Olsson, B., Ågren, G.I. and Linder, S., 2007. Impact of long-term nitrogen addition on carbon stocks in trees and soils in northern Europe. Biogeochemistry, 89, 121-137.

Indufor, 2013. Indufor databank.

Jeong, S.-J. et al., 2011. Phenology shifts at start vs. end of growing season in temperate vegetation over the Northern Hemisphere for the period 1982-2008. Global Change Biology, 17, 2385-2399.

Kellomäki, S., Maajärvi, M., Strandman, H., Kilpeläinen, A. and Peltola, H., 2010. Model computations on the climate change effects on snow cover, soil moisture and soil frost in the boreal conditions over Finland. Silva Fennica, 44, 213-233.

Kellomäki, S., Peltola, H., Nuutinen, T., Korhonen, K.T. and Strandman, H., 2008. Sensitivity of managed boreal forests in Finland to climate change, with implications for adaptive management. Philosophical Transactions of the Royal Society, B: Biological Sciences, 363(1501), 2341-2351.

Kilpeläinen, A., Kellomäki, S., Strandman, H. and Venäläinen, A., 2010. Climate change impacts on forest fire potential in boreal conditions in Finland. Climatic Change, 103, 383-398.

Kinnunen, R. et al., 2013. Impact of climate change on the boreal forest in Finland and Sweden. Helsinki University Centre for Environment (HENVI).

Kirilenko, A.P. and Sedjo, R.A., 2007. Climate change impacts on forestry. PANS, 104(50), 19697-19702.

Kukkola, M. and Nöjd, P., 2000. Increase in growth of the Finnish upland forests in 1950-1998 due to fertilisation. Metsätieteen aikakauskirja, 4, 603-612. (In Finnish.)

Linder, M. et al., 2008. Impacts of climate change on European forests and options for adaptation. Report to the European Commission Directorate-General for Agriculture and Rural Development.

Linkosalo, T., Leppalainen, H.K. and Hari, P., 2008. A comparison of phenological models of leaf bud burst and flowering of boreal trees using independent observations. Tree Physiology, 28, 1873-1882.

Marini, L., 2012. Climate affects severity and altitudinal distribution of outbreaks in an eruptive bark beetle. Climatic Change, 115(2), 327-341. 
Menzel, A., Estrella, N., Heitland, W., Susnik, A., Schleip, C. and Dose, V., 2008. Bayesian analysis of the species-specific lengthening of the growing season in two European countries and the influence of an insect pest. International Journal of Biometeorology, 52, 209-218.

Nikulin. G., Kjellström, E., Hansson, U., Strandberg, G. and Ullerstig, A., 2011. Evaluation and future projections of temperature, precipitation and wind extremes over Europe in an ensemble of regional climate simulations. Tellus A, 63, 41-55.

Norden, 2013. Biodiversity, carbon storage and dynamics of old northern forests. Copenhagen, Denmark: Norden.

Nordic Family Forestry (NFF), 2013. Available at: http://www.nordicforestry.org/ default.asp.

Nordli, O., Wielgolaski, F.E., Bakken, A.K., Hjeltnes, S.H., Mage, F., Sivle, A. and Skre, O., 2008. Regional trends for bud burst and flowering of woody plants in Norway as related to climate change. International Journal of Biometeorology, 52, 625-639.

Peltola, H., Ikonen, V.-P., Gregow, H., Strandman, H., Kilpeläinen, A., Venäläinen, A. and Kellomäki, S., 2010. Impacts of climate change on timber production and regional risks of wind-induced damage to forests in Finland. Forest Ecology and Management, 260, 833-845.

Peñuelas, J., Rutishauser, T. and Filella, I., 2009. Phenology feedbacks on climate change. Science, 324, 887-888.

Pudas, E., Leppala, M., Tolvanen, A., Poikolainen, J., Venalainen, A. and Kubin, E., 2008. Trends in phenology of Betula pubescens across the boreal zone in Finland. International Journal of Biometeorology, 52, 251-259.

Räisänen, J. and Eklund, J., 2012. 21st century changes in snow climate in Northern Europe: a high-resolution view from ENSEMBLES regional climate models. Climate Dynamics, 38, 2575-2591.

Richardsona, A.D., Keenana, T.F., Migliavaccab, M., Ryua, Y., Sonnentaga, O. and Toomeya, M., 2013. Climate change, phenology, and phenological control of vegetation feedbacks to the climate system. Agriculture and Forest Meteorology, 169, 156-173.

Routa, J., Kellomäki, S. and Peltola, H., 2012. Impacts of intensive management and landscape structure on timber and energy wood production and net $\mathrm{CO}_{2}$ emissions from energy use of Norway spruce. Bioenergy Research, 5, 106-123.

Sathre, R. and O'Connor, J., 2010. A synthesis of research on wood products and greenhouse gas impacts. Technical Report, 2nd Edition. Vancouver, Canada: FPInnovations.

Statistics Finland, 2012. Greenhouse gas emissions in Finland 1990-2010. National inventory report under the UNFCCC and the Kyoto Protocol.

Stokland, J.N. et al., 2003. Forest biodiversity indicators in the Nordic countries - status based on national inventories. Copenhagen, Denmark: Nordic Council of Ministers.

Wotton, B.M., Nock, C.A. and Flannigan, M.D., 2010. Forest fire occurrence and climate change in Canada. International Journal of Wildland Fire, 19, 253-271. 


\section{Plant and animal health and food safety}

\subsection{Introduction - health impacts of climatic factors}

In Europe, spring now starts 2-3 weeks earlier than it did before the 1980 s, thus increasing the length of the vegetation season (Trenberth et al. 2007). Long time series (130 years of monthly mean temperatures from seven Norwegian stations) show that the vegetation season has increased for all stations by 10-20 days/100 years in the 1871-1990 period (Hanssen-Bauer and Førland 2000).

In addition to the increase in mean temperature, current climate change is expected to increase climate variability (Trenberth et al. 2007). Predictive disease models typically use means and ignore fluctuations. In order to predict climate change responses it is necessary to understand how the individual species in different parts of the world respond to climate variability (Dillon et al. 2010). Random temperature variations are poorly understood, but may represent underappreciated links between climate change and disease transmission.

Approximately $60 \%$ of all human pathogens are zoonoses, infectious diseases transmitted from animals to humans or vice-versa (http://www.cdc.gov/nczved/), and climate is an important factor affecting the diversity and abundance of pathogens. At least 900 different zoonotic diseases are known, with reservoirs mainly among wild animals (Taylor et al. 2001). Transmission of infectious diseases between wild and domestic animals has become an issue of major interest.

Understanding the magnitude of the impact of climate change is challenging because the understanding of disease ecology is incomplete. Moreover, it is difficult to disentangle the effects of climate change alone. Determining the role of climate will require greater understanding of pathogen persistence. Another complicating factor is that in addition to its potential effect on species performance, climate change may also affect species interactions. Biotic interactions can mask the climatic change effect on populations (Araujo and Luoto 2007). Social, political, anthropogenic, economic and land-use changes also influence the ecology of disease (Randolph 2004). Knowledge of the relationship between 
climate and disease is a prerequisite for any attempt to forecast how future climate change is likely to affect human and animal health.

\subsection{Vector-borne diseases}

Vector-borne diseases are the most likely to be affected by, and the most studied candidates with regard to the effect of, climatic factors because vectors, such as insects and ticks, are unable to regulate their own body temperature, and are thus sensitive to variation in temperature and moisture (Macleod 1932). The development of pathogens within the vectors is also temperature dependent. These direct links between biological and climatic parameters make vector-borne diseases particularly interesting in the context of environmental and climate change. To predict or assess the outcome of interactions between vector, pathogen, host and environment, which is also embedded in a social and economic framework, is certainly far from easy. The complexity, scale and natural variability of the systems involved are inherently challenging. Organisms that cause disease in humans and animals are part of every ecosystem, but disease dynamics has mainly been studied using mathematical models that often do not take complex environmental information into account.

\subsection{Bluetongue}

Bluetongue (BT) is a vector-borne, non-contagious viral disease affecting ruminants. The virus (BTV) is transmitted by biting midges (Culicoides spp). Before 1998, BT was present worldwide between the latitudes of $35^{\circ} \mathrm{S}$ and $40^{\circ} \mathrm{N}$. Since then, the disease has also become endemic in Southern Europe (Maclachlan et al. 2009).

In 2006, BT caused by bluetongue virus serotype 8 (BTV 8) was discovered in the Netherlands and the disease spread rapidly to the neighbouring countries of Germany, Belgium, France and Luxembourg. Over the subsequent three years, BTV 8 spread to most European countries, including Denmark, Sweden and Norway. The original source of the BTV 8 infection and the route of introduction into the Netherlands were thoroughly studied, but investigations were fruitless. However, molecular genetic studies led to the assumption that the origin of the virus was in sub-Saharan Africa (Carpenter et al. 2009). The BTV 8 strain caused serious symptoms in cattle, with feverish, generalised disease and reproductive disorders such as abortion, stillbirth and congenital deformi- 
ties of the offspring. The outbreak was controlled by vaccination of at least $80 \%$ of the ruminant population in most of the affected countries (Ganter 2014).

The vector is the key for transmission of BTV between animals. The female midge requires a blood meal each time it lays eggs. The midge must complete at least two blood meals in order to pass the BTV infection on to a new susceptible animal. Between those two meals, the virus has to replicate and be released in the salivary gland of the midge. Viral replication is temperature dependent, and the virus ceases to replicate at temperatures below $12-15^{\circ} \mathrm{C}$. Midges survive the winter as larva, but for larva to become adult midges, the middle temperature during the day must be above $10-12{ }^{\circ} \mathrm{C}$.

Before 2006, the assumption was that only a few defined species of biting midges from tropical or subtropical areas were able to transmit BTV. When BT infections became endemic in the Mediterranean area of Europe, the most likely explanation was a range expansion of the vector (Culicoides imicola) into Europe due to a warmer climate. The 2006 outbreak was unexpected because the appropriate midge species was not present in the Netherlands or elsewhere in Northern Europe. However, it appears that some of the species already located in Northern Europe were capable of transmitting BTV 8. Meteorological data from Europe shows an increase in the middle temperature by $1.2^{\circ} \mathrm{C}$ in the past 100 years. As in the rest of Europe, Norway has seen approximately the same pattern of temperature increase (Miljøstatus i Norge 2006). In addition to temperature, humidity plays an important role in the midge's survival, but it is not normally a limiting factor in Northern Europe.

The effect of a milder climate with shorter winter periods and higher summer temperatures may have contributed to increased density of biting midges and extended the vector active period during the year. The habitat in which the midges can survive has been extended as well. Higher mean temperature will also prolong the periods in which virus replication can occur. These factors may have enabled the midge species in Northern Europe to become efficient BTV transmitters.

In Norway, four BTV-positive cattle herds were identified in the southern part of the country after testing of bulk milk samples collected in 2008. An examination of meteorological data from Denmark and Norway proved that the infected midges were transferred from Denmark to Norway by the wind only once, in August or September. Only a small number of cattle were found to be infected in three of the herds, whereas in the fourth herd almost all of the lactating cows were seropositive. There is reason to believe that a local virus replication had oc- 
curred in the midges at this location, and that these subsequently infected other susceptible cattle. Denmark and Sweden began vaccinating the ruminant population in 2008. Norway decided not to vaccinate. The infected geographical area was quite small and the long winter makes survival of infected adult midges impossible, in contrast to warmer parts of the world where survival of infected adult midges ensures BTV transmission from one season to the next. The birth of BTV-infected calves would probably be the only way the virus could survive the winter in Norway. A thorough surveillance programme successfully detected infected herds and animals. The comprehensive vaccination programmes implemented in Norway's neighbouring countries prevented airborne carriage of infected midges. After two years of extensive surveillance, Norway regained its official status as bluetongue-free.

\subsection{Tick-borne diseases}

Figure 8.1: Distribution of Ixodes ricinus, the castor bean tick, in Norway

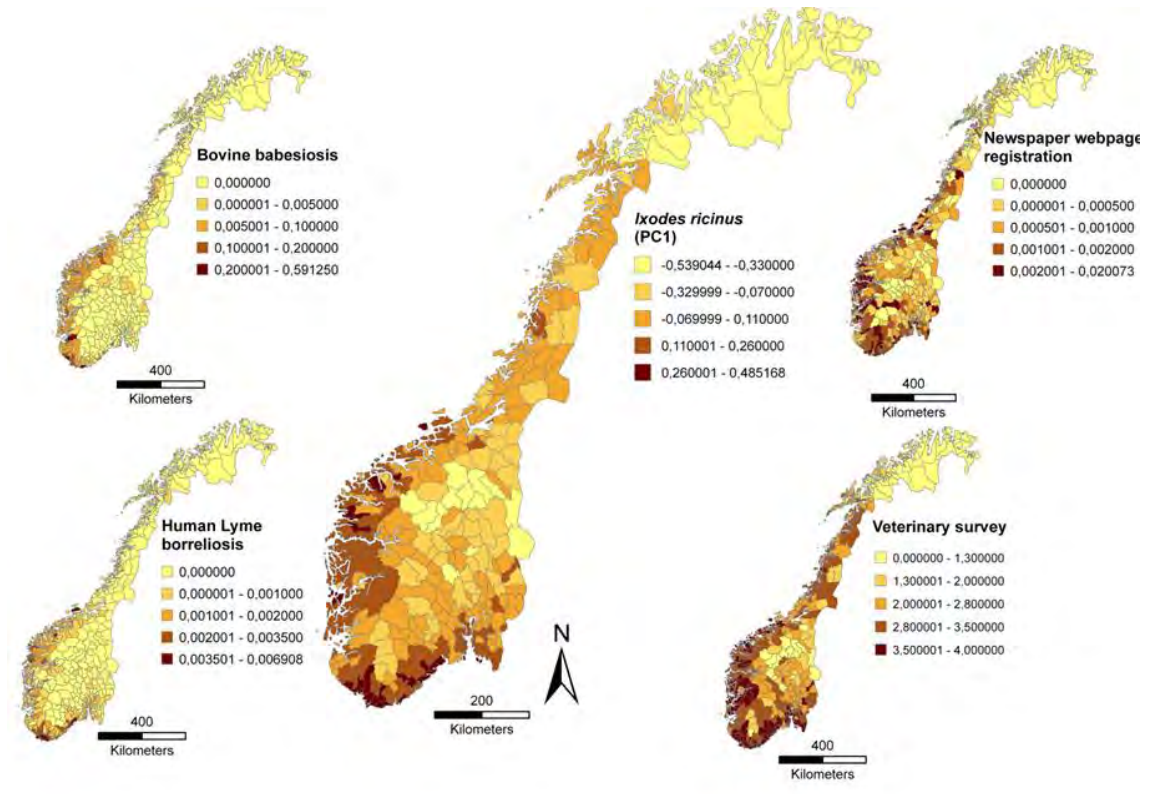

Figure 8.1 shows the present distribution of Ixodes ricinus (I. ricinus), the castor bean tick, in Norway, depicted by (a) the first principal component (PC1) of four different sources (b-e). The PC1 map displays tick abundance within municipalities by increasing darkness of colour. The smaller maps show: (b) the number of registrations of bovine babesiosis in the Norwegian Cattle Health Recording System in the 1996-2008 
period; (c) all notified cases of human Lyme borreliosis in the Norwegian Surveillance System for Communicable Diseases in the 1990-2008 period; (d) tick observations registered via a newspaper webpage during summer 2009; and (e) the frequency of tick observations from the veterinary survey performed in 2009, categorised as 0: never observed, 1: rarely ( $<3$ tick observations during a year), 2: monthly observation, 3 : weekly observation, 4 : daily observation. Each of the variables is depicted on a municipal basis.

Vector-borne diseases were recently identified by 30 European ministries of health as the biggest health threat arising from environmental change (Randolph 2009). The two most prevalent tick-borne human diseases in Europe, Lyme borreliosis (LB) and Tick-borne encephalitis (TBE), were ranked first and second respectively (Randolph 2009). This highlights the importance of learning more about current and future distribution ranges of the vector of these diseases: the castor bean tick, $I$. ricinus. In recent years, there has been an undocumented view in Norway that tick abundance has increased and the tick distribution range has expanded. There is also increasing evidence of a latitudinal and altitudinal shift in the distribution range of I. ricinus in other European countries (Gray et al. 2009). The reported incidence of tick-borne disease in humans is on the rise in many European countries, generating political concern and attracting media attention. The factors that are responsible for these trends are disputed, but many ascribe shifts in distribution range to climate change. Impacts are likely to be biggest at the fringe of the distribution of vectors and diseases. Detecting changes in distribution of vectors and diseases can facilitate understanding of the relationship between climate and zoonotic diseases.

A 2009 study (see Figure 8.1) described the distribution of I. ricinus in Norway and evaluated whether any range shifts had occurred relative to historical descriptions. Multiple data sources, such as tick-sighting reports from veterinarians, hunters and the general public, and surveillance of human and animal tick-borne diseases were compared in order to describe the present distribution of I. ricinus in Norway. The tick has expanded its northern distribution limit by approximately $400 \mathrm{~km}$ and is found at higher altitudes than described in historical records from 1943 to 1983 (Jore et al. 2011).

Modelling of climatic, environmental and demographic variables and abundance of wild cervids and domestic animals revealed that large diurnal fluctuations in ground surface temperature, spring precipitation, duration of snow cover, abundance of red deer/farm animals and bush encroachment were significant predictors of tick presence (Jore et al. 
2014). These results highlight the need to consider year-round climatic variables in order to disentangle seasonal variations, climatic threshold changes and climate variability and to consider broader environmental change. Tick and tick-borne disease distributions are dependent on a complex combination of climatic and environmental factors, including those related to human activities.

\subsection{Campylobacteriosis}

Human campylobacteriosis, caused by the bacterium Campylobacter, is the most reported bacterial diarrheal disease in the EU and the Nordic countries (European Food Safety Authority 2014). It is an acute diarrheal disease, and the infection dose can be low. Campylobacter bacteria are widespread, and are found in the natural environment and in the gastrointestinal tract of birds and mammals. The bacteria cannot grow outside warm-blooded hosts. Because birds and mammals can carry the bacterium without having symptoms, they act as a reservoir, spreading the bacteria to humans, other animals and the environment.

The incidence rate in 2012 for human campylobacteriosis in the Nordic countries varied between 19/100,000 and 83/100,000 inhabitants, where approximately $50 \%$ of the cases were domestic (European Food Safety Authority 2014). The frequency of campylobacteriosis cases and broiler chicken flocks carrying the bacteria follows a seasonal pattern, with a sharp peak in summer. This indicates that climatic factors may be important for the occurrence of the disease (Jonsson et al. 2012, Jore et al. 2010, Nylen et al. 2002).

A number of studies have identified drinking water, especially undisinfected drinking water, and food items such as poultry meat as sources of campylobacteriosis (Domingues et al. 2012, Ethelberg et al. 2005, Kapperud et al. 2003, Kapperud et al. 1992). The European Food Safety Authority (2010) reported that $20-30 \%$ of the human cases may be the direct result of handling and consumption of broiler meat, whereas 50$80 \%$ may be indirectly associated with broilers acting as a reservoir of the pathogen.

Norwegian studies of Campylobacter in broiler flocks showed that the proportion of infected flocks was higher at daily mean temperatures above $+6{ }^{\circ} \mathrm{C}$. Furthermore, the proportion of infected animals increased significantly with increasing temperatures above $+6{ }^{\circ} \mathrm{C}$ (Jonsson et al. 2012). A higher proportion of infected flocks led to a higher proportion of infected meat and a higher degree of spread into the environment. 
These findings correspond well with an Icelandic study in which outdoor temperatures above $+4{ }^{\circ} \mathrm{C}$ were associated with a higher risk of infection to a flock (Guerin et al. 2008).

A Danish study showed that there is a large influx of flies that carry Campylobacter into broiler houses despite bio-security measures (Hald et al. 2004). Houseflies cease egg laying at $+10{ }^{\circ} \mathrm{C}$ and are totally inactive below $+7^{\circ} \mathrm{C}$ (Guerin et al. 2008). Thus, there is reason to believe that the infection of broiler flocks in the Nordic countries is strongly dependent on temperature-driven fly activity. Moreover, environmental Campylobacter itself is sensitive to low temperatures. Temperatures below $0{ }^{\circ} \mathrm{C}$ have been shown to be protective against Campylobacter infection in broilers (Jonsson et al. 2012).

Rainfall appears to be another environmental factor influencing Campylobacter infection rates. Heavy rain ( $>15 \mathrm{~mm}$ in one day) has been shown to be associated with a substantially higher risk of infection to a broiler flock (Jonsson et al. 2012). Flooded farmyards could be a source of runoff of Campylobacter into the broiler house, water supply, the surroundings and nearby streams (Edwards et al. 2008, Ogden et al. 2007). It is also difficult to maintain bio-security in a flooded farmyard, and contaminated boots etc. can easily transmit the bacteria into the house.

\subsection{Moulds and mycotoxins}

Fungi are present in almost all environments and have immense ability to adapt to their surroundings. Moulds (filamentous microfungi) may have diverse impacts on humans and animals, and are the subject of increasing attention for their role as agents of human health problems (Beck-Sauget et al. 1993, Jacob et al. 2002, Patterson 2005, Zander 2005, Denning et al. 2006). Moulds may be implicated in three categories of disease in humans and animals: infections (mycoses), allergies and toxicoses. It is estimated that about $10 \%$ of the US population has IgE antibodies to fungi, with half of these expected to show clinical illness. The anticipated warmer, wetter and wilder climate will likely lead to qualitative and quantitative changes in fungal diversity, and subsequently to more and different mycotoxins as well.

Particular attention has been given to the possible health effects of fungi and mycotoxins in food, feed, drinking water and indoor air. Mycotoxins can induce toxic responses in vertebrates or other animals when fed at low concentrations. They can provoke mutagenic, teratogenic, oestrogenic and carcinogenic effects, and may damage cells of major 
organs such as the liver, kidney and lungs, as well as the nervous, endocrine and immune systems (Bhatnagar et al. 2002). So far, more than 300 mycotoxins have been identified, but only a limited number of these have been studied in detail.

Most mycotoxins of concern are produced by three genera of fungi, namely Aspergillus, Penicillium and Fusarium. The two latter genera constitute the largest problem in temperate regions of the world, while the genus Aspergillus is the main problem in warmer climates (Samson et al. 2004). However, it may take only small changes in the climate to alter this picture.

Climate change has already had an impact on mycotoxigenic fungal diversity. A change in fungal species, such as Fusarium, has been observed in Norway, implying a subsequent change in the mycotoxins produced (see Figure 8.2). Up to now, aflatoxins have not been produced in Norway, but only slight climatic changes could provide the right conditions for Aspergillus to produce these toxins, as aflatoxin production has already been confirmed in Skåne, Sweden (Petterson et al. 1989). Climatic changes may thus lead to new feed and food safety concerns of significance for society, the business sector and the authorities.

Figure 8.2: The amount of Fusarium and one of their mycotoxins in Norwegian oat in 2005-2013

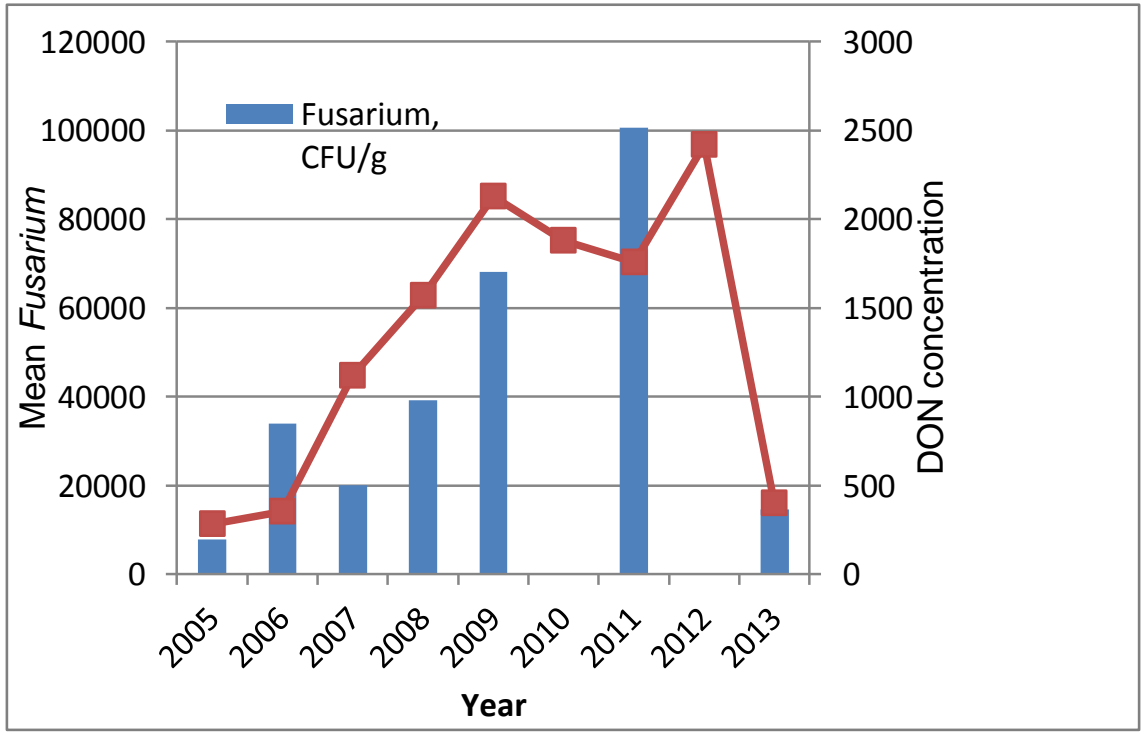

Among all the fungal species described, about 500 are allergenic, toxigenic or opportunistic fungi associated with human disease. Fungal diseases in humans usually originate from an exogenous source in the envi- 
ronment and are acquired through inhalation, ingestion or traumatic implantation.

There is increasingly greater focus on moulds as agents of infection in immunocompromised individuals, such as AIDS, cancer or transplant recipient patients undergoing hospital treatment (Gené et al. 2001, White 2005, Kauffman 2006, Nucci and Anaissie 2006). The costs of using antifungal medicine have skyrocketed in many hospitals in recent years.

Chronic rhinosinusitis (CRS) is a common disease in humans all over the world, including Norway. The cause of CRS is not well understood, but the potential role of fungi in causing CRS has likely been underestimated. Aspergillus species appear to be the main causal agent both in humans and in animals such as dogs, and thus a warmer and more humid climate may increase problems with CRS.

Mould growth on building materials in private homes and indoor work environments is an emerging problem in relation to fungi and human environments. Climate change in combination with tightly sealed and well-insulated buildings may increase problems with moulds in the indoor environment. Such mould growth may result in adverse health effects referred to as the "sick building syndrome" (Cooley et al. 2004). Symptoms include, but are not limited to, allergies, asthma, eye irritation, cough, dry or sore throat, nasal congestion, headaches, muscle pain, memory loss, concentration difficulties, skin rashes, nosebleeds, balance difficulties and extreme fatigue.

To learn more about the risk of exposure as well as the effect and fate of fungi and their metabolites in the body, it will be necessary to study fungi and mycotoxins in the context of climate change across a broad spectrum of disciplines.

\subsection{References}

Araujo, M.B. and Luoto, M., 2007. The importance of biotic interactions for modelling species distributions under climate change. Global Ecology and Biogeography, 16, 743-753.

Beck-Sauget, C.M., Jarvis, W.R. and the National Nosocomial Infections Surveillance System, 1993. Secular trends in the epidemiology of nosocomial fungal infections in the United States, 1980-1990. Journal of Infectious Diseases, 167, 1247-1251.

Bhatnagar, D., Yu, J. and Ehrlich, K.C., 2002. Toxins of filamentous fungi. In: M. Breitenbach, R. Crameri and S.B. Lehrer, eds. Fungal Allergy and Pathogenicity. Basel, Switzerland: Karger. pp.167-206.

Carpenter, S., Wilson, A. and Mellor, P.S., 2009. Culicoides and the emergence of bluetongue virus in northern Europe. Trends in Microbiology, 17, 172-178. 
Cooley, J.D., Wong, W.C., Jumper, C.A. and Straus, D.C., 2004. Fungi and the indoor environment: Their impact on human health. Advances in Applied Microbiology, 55, 3-30.

Denning, D.W., O’Driscoll, B.R., Hogaboam, C.M., Bowyer, P. and Niven, R.M., 2006. The link between fungi and severe asthma: a summary of the evidence. European Respiratory Journal, 27, 615-626.

Dillon, M.E., Wang, G. and Huey, R.B., 2010. Global metabolic impacts of recent climate warming. Nature, 467, 704-706.

Domingues, A.R., Pires, S.M., Halasa, T. and Hald, T., 2012. Source attribution of human campylobacteriosis using a meta-analysis of case-control studies of sporadic infections. Epidemiology and Infection, 140, 970-981.

Edwards, A.C., Kay, D., McDonald, A.T., Francis, C., Watkins, J., Wilkinson, J.R. and Wyer, M.D., 2008. Farmyards, an overlooked source for highly contaminated runoff. Journal of Environmental Management, 87, 551-559.

Ethelberg, S., Simonsen, J., Gerner-Smidt, P., Olsen, K.E. and Molbak, K., 2005. Spatial distribution and registry-based case-control analysis of Campylobacter infections in Denmark, 1991-2001. American Journal of Epidemiology, 162, 1008-1015.

European Food Safety Authority, 2014. The Community Summary Report on Trends and Sources of Zoonoses and Zoonotic Agents in the European Union in 2012. EFSA Journal.

Ganter, M., 2014. Bluetongue disease - Global overview and future risks. Small Ruminant Research. Available at: http://dx.doi.org/10.1016/j.smallrumres.2013.12.011.

Gené, J., Azón-Masoliver, A., Guarro, J., De Febrer, G., Martínez, A, Grau, C., Ortoneda, M. and Ballester, F., 2001. Cutaneous infection caused by Aspergillus ustus, an emerging opportunistic fungus in immunosuppressed patients. Journal of Clinical Microbiology, 39, 1134-1136.

Gray, J.S., Dautel, H., Estrada-Pena, A., Kahl, O. and Lindgren, E., 2009. Effects of climate change on ticks and tick-borne diseases in Europe. Interdisciplinary Perspectives on Infectious Diseases, 2009, 593232.

Guerin, M.T., Martin, S.W., Reiersen, J., Berke, O., McEwen, S.A., Fridriksdottir, V., Bisaillon, J.R., Lowman, R. and the Campy-on-Ice Consortium, 2008. Temperature-related risk factors associated with the colonization of broiler-chicken flocks with Campylobacter spp. in Iceland, 2001-2004. Preventive Veterinary Medicine, 86, 14-29.

Hald, B., Skovgard, H., Bang, D.D., Pedersen, K., Dybdahl, J., Jespersen, J.B. and Madsen, M., 2004. Flies and Campylobacter infection of broiler flocks. Emerging Infectious Diseases, 10, 1490-1492.

Hanssen-Bauer I., Drange, H., Førland, E.J., Roald, L.A., Børsheim, K.Y., Hisdal, H. et al., 2009. Climate in Norway: Background material to the NOU Climate Adaption. Oslo, Norway: Norsk klimasenter.

Hanssen-Bauer, I. and Førland, E.J., 2000. Temperature and precipitation variations in Norway 1900-1994 and their links to atmospheric circulation. International Journal of Climatology, 20, 1693-1708.

Jacob, B., Ritz, B., Gehring, U., Koch, A., Bischof, W., Wichmann, H.E. and Heinrich, J., 2002. Indoor exposure to molds and allergic sensitization. Environmental Health Perspectives, 110, 647-653.

Jonsson, M.E., Chriel, M., Norstrom, M. and Hofshagen, M., 2012. Effect of climate and farm environment on Campylobacter spp. colonisation in Norwegian broiler flocks. Preventive Veterinary Medicine, 107, 95-104. 
Jore, S., Viljugrein, H., Hofshagen, M., Brun-Hansen, H., Kristoffersen, A., Nygard, K., Brun, E., Ottesen, P., Saevik, B. and Ytrehus, B., 2011. Multi-source analysis reveals latitudinal and altitudinal shifts in range of Ixodes ricinus at its northern distribution limit. Parasites \& Vectors, 4, 84.

Jore, S., Vanwambeke, S.O., Viljugrein, H., Isaksen, K., Kristoffersen, A.B., Woldehiwet, Z., Johansen, B., Brun, E., Brun-Hansen, H., Westermann, S., Larsen, I.L., Ytrehus, B. and Hofshagen, M., 2014. Climate and environmental change drives Ixodes ricinus geographical expansion at the northern range margin. Parasites \& Vectors, 7, 11

Jore, S., Viljugrein, H., Brun, E., Heier, B.T., Borck, B., Ethelberg, S., Hakkinen, M., Kuusi, M., Reiersen, J., Hansson, I., Engvall, E.O., Lofdahl, M., Wagenaar, J.A., van Pelt, W. and Hofshagen, M., 2010. Trends in Campylobacter incidence in broilers and humans in six European countries, 1997-2007. Preventive Veterinary Medicine, 93, 33-41.

Kapperud, G., Espeland, G., Wahl, E., Walde, A., Herikstad, H., Gustavsen, S., Tveit, I., Natas, O., Bevanger, L. and Digranes, A., 2003. Factors associated with increased and decreased risk of Campylobacter infection: a prospective case-control study in Norway. American Journal of Epidemiology ,158, 234-242.

Kapperud, G., Skjerve, E., Bean, N.H., Ostroff, S.M. and Lassen, J., 1992. Risk factors for sporadic Campylobacter infections: results of a case-control study in southeastern Norway. Journal of Clinical Microbiology, 30, 3117-3121.

Kauffman, C.A., 2006. Fungal infections. Proceedings of the American Thoracic Society, 3, 35-40.

Macleod, J.A.J., 1932. The binomics of Ixodes ricinus L., the "sheep tick" of Scotland. Parasitology, 24, 382-400.

Maclachlan, N.J., Drew, C.P., Darpel, K.E. and Worwa, G., 2009. The pathology and pathogenesis of bluetongue. Journal of Comparative Pathology, 141, 1-16.

Miljøstatus i Norge. Middeltemperatur i Norge. Available at: http://www.mijostatus.no/templates/status_5171.aspx (12.12.2006).

Nucci, M. and Anaissie, E., 2006. Emerging fungi. Infectious Disease Clinics of North America, 20, 563-579.

Nylen, G., Dunstan, F., Palmer, S.R., Andersson, Y., Bager, F., Cowden, J., Feierl, G., Galloway, Y., Kapperud, G., Megraud, F., Molbak, K., Petersen, L.R. and Ruutu, P., 2002. The seasonal distribution of campylobacter infection in nine European countries and New Zealand. Epidemiology and Infection, 128, 383-390.

Ogden, I.D., MacRae, M., Johnston, M., Strachan, N.J., Cody, A.J., Dingle, K.E. and Newell, D.G., 2007. Use of multilocus sequence typing to investigate the association between the presence of Campylobacter spp. in broiler drinking water and Campylobacter colonization in broilers. Applied and Environmental Microbiology, 73, 5125-5129.

Patterson, T.F., 2005. Advances and challenges in management of invasive mycoses. The Lancet, 366, 1013-1025.

Pettersson, H.A., Holmberg, T., Larsson, K. and Kaspersson, A., 1989. Aflatoxins in acid-treated grain in Sweden and occurrence of aflatoxin M1 in milk. Journal of the Science of Food and Agriculture, 48, 411-420. doi: 10.1002/jsfa.2740480403.

Randolph, S.E., 2004. Evidence that climate change has caused "emergence" of tickborne diseases in Europe? Internal Journal of Medical Microbiology, 293, Suppl. 37, 5-15.

Randolph, S.E., 2009. Tick-borne disease systems emerge from the shadows: the beauty lies in molecular detail, the message in epidemiology. Parasitology, 136, 1403-1413.

Samson, R.A., Hoekstra, E.S. and Frisvad, J.C., 2004. Introduction to food- and airborne fungi. Utrecht, the Netherlands: Centraalbureau voor Schimmelcultures. 
Taylor, L.H., Latham, S.M. and Woolhouse, M.E., 2001. Risk factors for human disease emergence. Philosophical Transactions of the Royal Society, B: Biological Sciences, 356(1411), 983-989.

Trenberth, K.E., Jones, P.D., Ambenje, R., Bojariu, D., Easterling, A., Tank, K. et al., 2007. Observations: Surface and Atmospheric Climate Change. In: Climate Change 2007: The Physical Science Basis. Contribution of Working Group I to the Fourth Assessment Report of the Intergovernmental Panel on Climate Change. Cambridge, UK, and New York, NY, USA: Cambridge University Press.

White, D.A., 2005. Aspergillus pulmonary infections in transplant recipients. Clinics in Chest Medicine, 26, 661-674.

Zander, M.D., 2005. Allergic bronchopulmonary aspergillosis. An overview. Archives of Pathology \& Laboratory Medicine, 129, 924-928. 


\section{Genetic resources}

\subsection{Plant genetic resources}

\subsubsection{Climate change and challenges for plant production}

Future climate changes will have clear ramifications for agricultural production. Elevated temperature and atmospheric concentrations of $\mathrm{CO}_{2}$ and ozone $\left(\mathrm{O}_{3}\right)$ have already been found to affect crop yields considerably (Pleijel et al. 1992, Long et al. 2006, Lobell and Field 2007, Trnka et al. 2012, Wilkinson et al. 2012). At the end of the 21st century, the temperature, $\mathrm{CO}_{2}$ and $\mathrm{O}_{3}$ levels and the frequency of extreme events are likely to increase; see Chapter 2 and IPCC (2013). This variation in the climate will pose challenges to primary production.

In the Nordic region, precipitation is projected to be more unevenly distributed during the summer and more frequent during the winter. The potential risk of summer drought alternating with heavy rain showers will require cultivars bred for a new rainfall pattern and may prompt changes in management practice, e.g. the date of sowing may be changed (Christensen et al. 2011). Changes in temperature, $\mathrm{CO}_{2}$ and $\mathrm{O}_{3}$ levels and precipitation may occur at an unprecedented pace, putting pressure on breeders for rapid delivery of crops fit for the new and more extreme environments. At the same time, nutrients (e.g. phosphorus) comprise a limiting factor for production improvements in relation to the ongoing environmental changes influencing primary production.

Societal demands to reduce the use of pest control agents, fertiliser and irrigation need to be dealt with as well (Tilman et al. 2001, Tilman et al. 2002, Foley et al. 2011). Due to the impacts of climate change, depletion of resources, demand for sustainability and growing production costs, FAO expects a slower growth in global agricultural production of $1.5 \%$ per year on average, compared with an annual growth of $2.1 \%$ between 2003 and 2012 (FAOSTAT 2012). Obviously, the challenge of feeding the increasing world population is enormous. 


\subsubsection{Cereal crops in the Nordic region}

Approximately 9 million ha is cultivated in the Nordic countries, and close to half of this area is currently used for growing cereals. Barley (Hordeum vulgare L.) is cultivated on $19 \%$ of the area, wheat (Triticum aestivum L.) on $14 \%$, oat (Avena sativa L.) on $7 \%$, and rye (Secale cereale L.) and triticale (Triticum ssp. $x$ Secale cereale) on $1 \%$ of the area, respectively (FAOSTAT 2012). Both winter and spring types of barley, wheat, rye and triticale are grown in the Nordic countries, with the spring types used more frequently in the northern parts of the region. Rye and triticale are mainly winter types, whereas oat is only a spring type in the Nordic countries; winter barley is only common in Denmark.

These cereal crops are used for feed, as well as for food, e.g. wheat and rye for bread, barley for malt and oats to some extent for functional foods. Intensive breeding to improve these crops has been carried out in the Nordic region for more than a century with the exception of triticale, which is a relatively new crop (Harlan 1976, Larter 1976, Høst 1982). It is expected that cultivation of winter cereals will move further north in the Nordic region due to higher temperatures, milder winters and longer growth seasons.

\subsubsection{Genetic diversity of cereal crops}

The genetic diversity of these cereal crops is essential for future breeding, since a decrease in genetic variability in general may result in a reduction in the ability of the crop to respond to environmental and agricultural changes (Hakala et al. 2012, Manifesto et al. 2001). The question is whether the diversity present in the Nordic breeding materials of cereal crops is sufficiently broad to meet the demands of the future climate conditions. Climate change may require adaptation to new combinations of abiotic and biotic stresses, e.g. high temperature and drought, and new pathogens or new races of existing pathogens (Parikka et al. 2012). Future quality needs for cereals will also create new challenges for breeders in the Nordic region.

The above emphasises the fundamental importance of phenotypic plasticity, e.g. adaptability acquired through high genetic variability. Studies of genetic diversity in Nordic spring barley and wheat indicate that genetic variation among modern varieties is not reduced compared with old accessions, e.g. landraces (Brantestam et al. 2007; Ortiz et al. 2002; Hysing et al. 2008). This is probably due to frequent introduction of exotic breeding lines by the Nordic cereal breeders during the latter part of the $20^{\text {th }}$ century. However, although genetic diversity is not di- 
minished by cereal breeding, diversity still not be sufficient to cope with the new and previously unencountered challenges. For example, stable production will be required across a range of different environments with an increasing frequency of climate extremes, e.g. where drought and heavy rains alternate during the growing period.

Landraces and older cultivars of cereal crops are obvious sources of genetic variation to be exploited in future breeding of cereals. Variation in environmental stress tolerance between and within landraces and cultivars has been little explored thus far (Luo et al. 2009, Ceccarelli et al. 2010, Anderson et al. 2011). Targeted breeding efforts should therefore involve screening of existing accessions for abiotic and biotic stress tolerance needed under climate change.

In the Nordic region, pre-breeding and breeding exploring the potential of genetic resources in barley is performed by the Nordic Council of Ministers-funded network Sustainable Primary Production in a Changing Climate and by the Public-Private Partnership (PPP) on barley. In these two projects, more than 300 barley accessions are being phenotyped to record their tolerance to environmental stresses (e.g. temperature and changed atmospheric composition) and their resistance to plant disease. The observed phenotypes are linked to genetic markers of the accessions, as array-based single-nucleotide polymorphism (SNP) profiling makes association mapping possible. After verification of the linkage between the trait of interest and the SNP markers, markers can be transformed into easy-to-use PCR-based markers that can be handled efficiently in the laboratories of the breeding companies. Thus the use of these molecular techniques constitutes the foundation for effective cereal breeding for disease resistance and harvest stability under changing climatic conditions in the Nordic region.

\subsubsection{Perennial forage crops}

A major proportion of agricultural land in the Nordic countries is used for forage production. Forage-based milk and livestock production is very important economically, e.g. in 2007 the sector contributed $70 \%$ of the income from agriculture in Norway (Rognstad and Steinset 2008). The situation is similar in the other Nordic countries. In Norway, grasslands constitute about $68 \%$ of agricultural land, of which $35 \%$ is classified as short-term (temporary) leys (< 10 years old), $12.5 \%$ as leys over 10 years old, and about $20 \%$ as semi-natural and pasture grassland (Daugstad 2013). 
In northern and highland regions of Norway, northern parts of Sweden and Finland, and Iceland, more than $90 \%$ of agricultural land is grassland. Perennial grasses and legumes are the dominating forage crops in the Nordic region. Since grasslands constitute such a large part of the cultivated land in Northern Europe, the management and productivity of grasslands will have a great impact on society and the environment.

\subsubsection{Adaptational strategies for perennial grasses under climate change}

The forecasted climate change will have a profound effect on perennial grasses both during the growing season and during the winter season. Changes in the pattern of abiotic stress factors due to climate change will require development of new cultivars through adaptation and breeding. Higher temperature during the growing season will increase the developmental rate. Changed autumn and winter conditions will affect winter survival. Control of flowering time is highly important for effective utilisation of the extended growing season.

By delaying flowering time, and thereby utilising the extended growing season for vegetative growth, grasses would maintain a higher fodder quality for a longer period of time. A high proportion of elongating stems increases dry matter production per season in regions where few cuts can be taken; however, stems have lower nutritive value than leaves due to lignification. The dry matter yield can be increased by inducing more tiller elongation in late summer. To adapt to the extension of summer growth, it is necessary to search for genotypic variation in the formation of high-yielding elongating stems as well as to identify genes inhibiting/promoting stem elongation under restricting conditions.

The new cultivars should also be sufficiently winter hardy to withstand the expected winter stresses (Thorsen and Höglind 2010). Understanding the genetic regulation of adaptive traits such as flowering time, cold acclimation and winter survival is therefore crucial to developing new, improved and persistent high-yielding cultivars with optimum feeding value. Higher temperatures during the growing season, increased $\mathrm{CO}_{2}$ concentration and extended growing seasons should lead to higher biomass production with the possibility of increasing the number of cuts and extending the grazing season. This is especially important for grassland-based agriculture at higher latitudes where the effects of climate change are expected to be greatest.

At the same time, the seasonal distribution of precipitation is expected to change, with a general increase in climate variability among 
years. This poses great challenges for harvesting, conservation and grazing of the increased grassland biomass. In order to utilise the predicted longer growing season in the northern part of Scandinavia, cultivars that cease growth later in the autumn compared to the currently adapted cultivars are needed. The genotypes will have to use temperature relatively more extensively as an environmental cue indicating autumn, unlike the currently adapted cultivars, which use photoperiod. However, there is a trade-off between extended growth in the autumn and attainment of sufficient freezing tolerance through cold acclimation. Higher temperatures during autumn at short photoperiods will also hamper cold acclimation and lead to lower freezing tolerance.

\subsubsection{Genetic resources of perennial forage species}

Development of improved, adapted and high-yielding cultivars requires well characterised germplasms and knowledge about genetic and physiological regulation of traits that are important for sustainable forage production under expected climate change. It should be kept in mind that the combination of temperature and photoperiod, the two main environmental cues determining the seasonal growth pattern and winter survival of perennial plants, is unique in the north due to the influence of the North Atlantic Current.

There is very little or no commercial plant production at similar circumpolar latitudes. This means that there are very few potential sources for exotic germplasms if the decision is taken to enlarge the genetic diversity of the breeding materials in the Nordic region. The current understanding is that all plant species in Europe radiated from a few refuge regions (the Alps, Pyrenees and Caucasus) after the last glaciation. Most of the crop species have been introduced naturally or by humans in the south and have moved northwards in the past few hundred years. Thus it is highly possible that the current genetic diversity, especially in perennial crops, is rather restricted due to introduction from only a few sources. Genetic diversity studies of meadow fescue (Festuca pratensis) and timothy (Phleum pratense), two key forage grass species in the Nordic region, support this hypothesis (Rognli et al. 2013 and references therein).

\subsubsection{Available genetic resources}

Forage grasses and legumes are semi-wild crops with a large number of natural populations in the Nordic countries; many of them have been collected and are stored in the Nordic gene bank (NordGen). A large 
number of the NordGen accessions of forage grass species have been phenotyped and genotyped using molecular markers. Forage grasses and legumes are outbreeding species, and an overwhelming proportion (63-98\%) of the genetic variation is found within populations (Rognli et al. 2013 and references therein).

There are several reasons for this: extensive gene flow through pollen and seed (both natural and human-mediated), common ancestry of local populations, and gene flow from a few improved cultivars into local populations as indicated for continental local populations of meadow fescue (Festuca pratensis Huds.) in Norway (Fjellheim and Rognli 2005). These factors, combined with large effective population sizes that make genetic drift negligible, will effectively prevent population differentiation. The geographical structuring of molecular and phenotypic variation often does not coincide, and phenotypic variation in ecotypes is often as large as or larger than in cultivars (Fjellheim and Rognli 2005). Spatial differentiation for phenotypic traits is often found, indicating local adaptation to pedoclimatic factors and management. Local adaptation is evident among European timothy populations for traits such as winter survival, growth habit and traits related to seed production capacity, the latter being a sign of human-mediated selection influence (Fjellheim et al., unpublished).

Large genomes among forage grass species, population structure, low and variable linkage disequilibrium (LD), and a general lack of historical information about the origin of populations of forage crops make it challenging to link phenotype and genotype in these species. The rapid development of low-cost next-generation sequencing (NGS) techniques, e.g. genotyping-by-sequencing (GBS), holds great promise for genomewide, high-resolution SNP marker screening of populations (Poland and Rife 2012). This will make it possible to obtain an extremely detailed picture of the genetic architecture of populations and bridge the current genotype-phenotype gap.

Development of efficient methods for utilisation of wild adapted genetic resources and un-adapted exotic germplasm is necessary in order to develop new cultivars rapidly enough to keep pace with the altered growing conditions due to climate change. An example of how genetic diversity can be increased to secure adaptation to future climates is the Public-Private Partnership (PPP) on pre-breeding of perennial ryegrass (Lolium perenne). In the project $\sim 400$ accessions of perennial ryegrass are being phenotyped at several locations in the Nordic region, recombined to introgress exotic germplasms for two generations in Denmark and Norway, and genotyped by sequencing to estimate relatedness and 
develop tools for associating genome regions with traits. This long-term project is expected to develop both locally adapted germplasms with adaptations to specific climates/sites and germplasms with wide adaptations (phenotypically stable).

\subsection{Animal genetic resources}

\subsubsection{Introduction}

The goals of breeding programmes for commercial breeds should be critically evaluated in order to adapt to and mitigate the effects of climate change. In general, adaptation of livestock production and mitigation issues call for robust animals that have high productivity and efficiency, high fertility, good health and robustness, and produce less GHG emissions. The genetic variation within the active breeds should be maintained in order to preserve the potential for future genetic gains in animal breeding programmes. In addition, in order to meet future challenges and maintain flexibility in future livestock production, maximum genetic diversity within the domestic animal species and diversity among breeds should be maintained, i.e. locally adapted breeds and populations should be conserved and their traits investigated.

\subsection{Mitigation and adaptation require robust animals}

Livestock production is responsible for a significant share of the GHG emissions in the Nordic countries (see Chapter 2). It is necessary to adjust production systems, including the use of farm animal genetic resources and animal breeding, to reduce emissions from livestock production. The key issue is the reduction of $\mathrm{CH}_{4}$ emissions from ruminants, especially from beef and dairy cattle. Microbial fermentation of feed components in rumen results in high amounts of enteric $\mathrm{CH}_{4}$. Manipulation of feeding affecting rumen microbial populations is one promising approach for decreasing the level of $\mathrm{CH}_{4}$ emissions. For example, increasing the energy density of the diet decreases $\mathrm{CH}_{4}$ production per unit of digestible energy consumed. Selection is the other major option for mitigation of GHG emissions from livestock (ruminant) production systems.

Variation in $\mathrm{CH}_{4}$ emissions exists both within and between cattle breeds, indicating a potential for improvement of the trait through genetic selection. However, repeatability between successive measure- 
ments of $\mathrm{CH}_{4}$ emissions in experiments has been low and heavily dependent on the diet and physiological stage of the animals. Developing methods for collecting data on $\mathrm{CH}_{4}$ emissions on farms for inclusion as a trait in breeding programmes is very challenging.

Nevertheless, the trait can be improved indirectly through selection of traits that have correlated effects on emissions. Valuable traits of domestic animals under changing agroecological conditions are fertility, health, residual feed intake, longevity and production efficiency. Higher productivity leads to improved feed conversion into products, and thus fewer animals will be needed to meet the demand for animal products. If animals are fertile and healthy, there will be less culling and fewer animals will be needed for replacement. Improving fertility will improve pregnancy rates and reduce calving intervals, resulting in shorter unproductive periods. Improving calving and maternal traits will reduce emissions by improving survival of offspring. All these improvements will reduce both total and per unit product GHG emissions from livestock production systems. Fertility, health and other fitness traits have a genetic component and are therefore possible to improve by genetic selection. However, these traits are not easy to breed, as they typically have low heritability. Also, the breeding goal is generally based on an appraisal of the economic value of the traits. Economic incentives are needed to encourage farmers to include GHG emission in the breeding goal. In the Nordic countries, breeding goals are generally broad and incorporate production issues as well as many health characteristics that will help to breed the animals needed for future livestock production.

Breeds can become more adapted to specific environments through natural and artificial selection, enabling them to survive and be productive in these environments. Adaptations such as increased disease and heat resistance, improved water scarcity tolerance, ability to cope with poor quality feed etc. are valuable characteristics of a breed and will be important for adapting to and mitigating environmental changes. The important breeding goals for adaptation, such as fertility, feed conversation rate and particular health traits, are very similar to those for mitigation. These are typically either directly or indirectly considered in Nordic breeding programmes. However, good fertility e.g. in dairy cows is known to correlate negatively with genetic merit for milk production, so there is some conflict between different breeding goals of importance for future livestock production. 


\subsection{Available animal genetic resources}

There are three types of livestock breeds currently available: (1) the majority breeds, which are breeds that are most commonly used in commercial livestock production; (2) the minority breeds, which are also used in commercial herds but not very often (sometimes to create specialised, niche products, sometimes in special production circumstances); and (3) the rare breeds, which are generally kept for recreational purposes and rarely for production purposes.

The minority and rare breeds may possess genes that code for specific traits, such as disease resistance, that may become desirable to the majority breed owners if the majority breed does not possess the genetic variation that confers this trait. However, most of the time the majority breed can be selected for any desired trait, just like the rare breed was once selected for this trait, but it may take many generations to establish the desired trait in the majority breed. A rare or minority breed, in which the desired trait is established at a high frequency, may be used to establish the trait in commercial production circumstances. In this process, the minority breeds that possess the trait provide a much more useful resource than the rare breeds because when crossed with the majority breed their offspring will combine the desired trait with commercial viability (since both parental breeds are commercially viable).

Examples of this scenario are the use of Scandinavian Red bulls for US Holstein cows to improve the cows' fertility (Scandinavian Reds are considered a minority breed on the global cattle breeding scale), the use of Chinese Meishan pigs to improve fertility in some European pig breeding programmes, and the crossing of less fertile sheep breeds with the highly prolific Finnsheep. In general, minority and rare breeds comprise a valuable resource for enabling commercial breeding schemes to increase the rate at which desirable traits can be established in majority breeds. The minority breeds are especially beneficial in this context. Thus, to address future unforeseen production challenges such as those resulting from climatic changes and which require new, desired traits in majority breeds, it is important to maintain a large number of minority breeds that are improved for specialised production environments, as well as a smaller number of rare breeds. In the wake of climate change, the commercial and widespread breeds may exhibit shortcomings, e.g. insufficient resistance to a new disease. Minority breeds may have resistance to the new disease, and in extreme cases the minority breed will have to replace the commercial breed. In most cases, however, some form of introgression of the new trait into the commercial breed is 
needed. If the trait is due to a single or a few genes, these genes can be mapped and introgressed into the commercial breed (Ødegård et al. 2009). Although generally successful in plant breeding, this approach is often infeasible in livestock because most livestock traits are complex, i.e. highly multi-genic, and introgression takes $\sim 5$ generations, which in livestock can easily take 10 years or more. Crossbreeding systems can be devised that at least partly transfer the desired trait from the rare breed into the commercial breed. Alternatively, genomic selection introgression (GSI) can be employed (see below).

\subsubsection{Applications of the genomic selection approach}

Adaptation to and mitigation of climate change will require rapid adjustments of the genetics of livestock because many of the consequences of the changing climate are unforeseen. The fastest rate of genetic improvement is probably achieved by genomic selection (Meuwissen et al. 2001). Genomic selection is especially effective when the desired trait cannot be recorded on the animal that is being selected, and/or when the generation interval of the animals can be reduced, which increases the speed of the breeding scheme, e.g. in the case of genotype by environment ( $\mathrm{G} \times \mathrm{E}$ ) interactions. Here, the desired trait may be recorded in a different environment, e.g. production under different climatic conditions than the one where the elite breeding animal is living. Genomic selection schemes can be devised that accommodate these $\mathrm{G} \times \mathrm{E}$ interactions and/or record difficulties and then can be optimised with respect to their expected rates of genetic improvement (e.g. Lillehammer et al. 2011).

GSI is an efficient way to include a desired trait from a rare breed in a commercial, widespread breed. The assumption is that the rare breed is inferior to the commercial breed in terms of most traits, except for the desired trait. Thus neither the rare breed nor crossbreds between the rare and the commercial breed are commercially viable. The crossbreds may, however, be genetically improved through a genomic selection scheme and overtake the commercial breed (Ødegård et al. 2009), due to their increased genetic variance, especially for the desired trait. More research on the design and effectiveness of GSI is needed, since it appears to be a very effective strategy for the use of animal genetic resources. In crop plants, similar back-crossing schemes have been utilised extensively, especially for introgression of disease resistance genes from wild relatives into elite breeding lines (Goodman et al. 1987). Today, backcrossing and reconstitution of the desired recipient genotype is 
much more efficient than previously, due to the use of molecular marker assisted selection.

\subsubsection{Conservation of animal genetic resources}

In a situation where a majority breed widely dominates a production system, it is very important that the breed does not run into inbreeding problems, otherwise inferior alternative breeds, if they still exist, will have to be introduced into the production system. Inbreeding problems will also have to be avoided in the alternative minority and rare breeds in order to maintain viability over many future generations. Long-term selection experiments have shown that managed populations can be sustained without significant loss of genetic variation for $>100$ generations when the effective population size is maintained at 100 or more. Thus, to be on the safe side, the effective population size needs to be maintained at $100-200$, resulting in an inbreeding rate of $0.5-1 \%$ per generation. Optimal contribution theory provides a framework for maximising response to selection while controlling the effective population size (Meuwissen 1997). Software for optimum contribution selection exists, but improvements are needed in order to address the different situations that occur in practical breeding schemes.

In the conservation of animal genetic resources, characterisation of conservation values and adaptations of different breeds and populations is an important issue for more efficient use of genetic resources in the future. Modern research approaches in genomics provide useful tools for characterisation. Tens or hundreds of thousands of SNP markers can currently be analysed in farm animals using SNP BeadChips, which increases the probability of detecting loci under selection as well. Breeds showing adaptations in specific environments typically have a high conservation value for various future purposes. In addition to SNPs, wholegenome DNA sequencing provides valuable insights into evolution of domestic animal species. For example, the genome sequencing project on cattle breeds revealed that genes associated with reproduction, immunity, lactation and digestion have undergone remarkable changes during the evolution of cattle. The AnGR-NordicNET project has developed a new measure of valuing breeds for conservation called "adaptivity coverage." Adaptivity coverage quantifies how well a set of breeds could be adapted to a wide range of environments within a limited timespan. In this quantification, adaptivity coverage considers both neutral and non-neutral genetic variation. 


\subsection{Genetic resources in fish populations}

In the North Atlantic Ocean, and in rivers and lakes in the countries surrounding it, there are many ecologically and economically important fish stocks. Fish, as a class of vertebrates, show large genetic variation. Genetic variation is the raw material of evolution and a prerequisite for adaptation of populations due to natural selection. As such, genetic variation is essential for the potential of populations and species to adapt to changing environmental conditions such as global warming. Genetic techniques are increasingly being applied in various management and conservation activities throughout the world (e.g. Waples 1995, Fraser and Bernatchez 2001, Therkildsen et al. 2013). These activities include characterisation of genetic structure of populations and gene flow patterns, estimation of effective population sizes and studies on humaninduced hybridisation. In general, the main goal is to preserve or restore the evolutionary potential of populations and species, thus preserving biodiversity and often economically valuable resources. Furthermore, knowledge about structure and evolutionary potential of populations may improve modelling responses of populations and species to climate change (D'Amen et al. 2013, Therkildsen et al. 2013).

Salmonid species such Atlantic salmon (Salmo salar), brown trout (Salmo trutta) and Arctic char (Salvelinus alpinus) exploit a diverse range of environments and display considerable life-history and phenotypic variability (Klemetsen et al. 2003). This is exemplified through the complete freshwater residency of some populations vs. anadromy of others and through different age and timing of life-history events such as breeding, smolting and duration of ocean feeding. Phenotypic variation is most evident in Arctic char, where e.g. sympatric morphs (or phenotypes) are not uncommon and up to four morphs can be found within a single lake (Sandlund et al. 1992). The great phenotypic diversity and ecological segregation found among Arctic char morphs has created taxonomic problems where different morphs have often been considered different species (Adams and Maitland 2007, Klemetsen 2010). Indeed, Arctic char diversity is probably the best example of the adaptive divergence observed among post-glacial fish inhabiting the relatively species- poor and diverse environments in the Nordic countries and elsewhere in the Northern Hemisphere. Genetic studies have shown that different Arctic char morphs have evolved independently in multiple lakes (Gíslason et al. 1999), i.e. sympatric divergence, although allopatric divergence of sympatric populations has been observed as well (e.g. Verspoor et al. 2010). In the latter case, lakes have probably been colo- 
nised by different evolutionary lineages, i.e. by groups that may have been isolated for thousands of years in ice-free regions known as glacial refugia. Today, phylogeographic patterns of different salmonids have been linked to colonisation from different glacial refugium (Brunner et al. 2001, Säisä et al. 2005, McKeown et al. 2010, Finnegan et al. 2013). Although the phylogeography of salmonids has become clearer in recent years (Crête-Lafrenière et al. 2012), further studies are needed to resolve the full history (including mapping the geographical distribution of different lineages) and to characterise biological differences among intraspecific lineages. Importantly, do different lineages vary in characteristics that may affect their ability to respond to climate change?

Salmonids have been studied with genetic methods for decades. Overall, these studies show that salmonid species are highly structured, with varying levels of population differentiation (Allendorf et al. 1976, Hindar et al. 1986, Ståhl 1987, Primmer et al. 2006, Vähä et al. 2008). Comparative studies show that resident salmonids generally display lower levels of genetic diversity than marine fish species and higher levels of population differentiation, whereas anadromous salmonid populations display intermediate levels (Gyllensten 1985, DeWoody and Avise 2000). These trends are likely the result of comparatively lower effective population size of salmonid populations, which may be due not only to differences in census population size but also to limited or restricted gene flow among salmonid populations (Gyllensten 1985, DeWoody and Avise 2000). Gene flow among populations can be restricted by geographical factors and minimised by site fidelity or accurate homing to natal spawning areas (Taylor 1991). Restricted gene flow among salmonid populations enables local adaptation (Taylor 1991), which can be evidenced on small and large geographical scales (Fraser et al. 2011). Earlier salmonid studies on genetic diversity and population structure were mostly based on analysis of protein coding (allozyme) loci (e.g. Verspoor et al. 2005). Allozymes have generally lower resolution power than the more recently developed nuclear DNA markers, e.g. microsatellites (O'Connel and Wright 1997, Estoup et al. 1998). Also, DNA markers do not require fresh tissue samples, and polymerase chain reaction (PCR) technology enables the amplification of markers with a minute amount of DNA. As a result, historical samples, such as fish scales, are now commonly used sources of DNA for genetic studies of fish populations (Nielsen and Hansen 2008). Powerful statistical methods have also been developed for highly polymorphic markers, such as multilocus assignment and admixture analysis (e.g. Cornuet et al. 1999, Pritchard et al. 2000). Collectively, 
these advances have facilitated robust studies on factors that may influence the genetic diversity and population structure of salmonids, such as effects of habitat stability (Garant et al. 2000, Østergaard et al. 2003), riverscape (Ozerov et al. 2012) and landscape features (Dillane et al. 2008), carrying capacities of rivers (Ozerov et al. 2012), and lifehistory characteristics (Vähä et al. 2008). Furthermore, these methods have been used to assess the genetic effects of stocking with nonnative strains (Hansen et al. 2009, Perrier et al. 2013) and introgression of farmed salmon into wild populations (Glover et al. 2012, Gudmundsson et al. 2013), which may result in both breakdown of local adaptation and fitness reduction in wild populations (McGinnity et al. 2003, Bourret et al. 2011).

Historically and ongoing, anthropogenic disturbances have caused declines and extinctions of many salmonid populations (e.g. Parrish et al. 1998). How climate change will affect the present genetic resources of salmonid populations is largely unknown, and will depend on multiple factors, such as how fast and whether populations are able to adapt to new thermal conditions and to environmental and ecological changes overall. Ecological factors may involve changed predator-prey relationships, spread of disease and competition, either between native species or between native and alien species (Laikre et al. 2006, Hein et al. 2011). It is expected that generation time will get shorter at higher temperature, which may accelerate the process of natural selection and local adaptation. In contrast, global warming may induce migration and gene flow (Horreo et al. 2011), putatively counteracting such processes. Science-based management and conservation of salmonid populations, including their habitats, is one of the key factors in preserving their genetic variability and evolutionary potential in the face of climate change. 


\subsection{References}

Allendorf, F., Ryman, N., Stennek, A. and Ståhl, G., 1976. Genetic variation in Scandinavian brown trout (Salmo trutta L.): evidence of distinct sympatric populations. Hereditas, 83, 73-42.

Adams, C.E. and Maitland, P.S., 2007. Arctic charr in Britain and Ireland - 15 species or one? Ecology of Freshwater Fish, 16, 20-28.

Anderson, J.T., Willis, J.H. and Mitchell-Olds, T., 2011. Evolutionary genetics of plant adaptation. Trends in Genetics, 27, 258-266.

Bourret, V., O'Reilly, P.T., Carr, J.W., Berg, P.R. and Bernatchez, L., 2011. Temporal change in genetic integrity suggests loss of local adaptation in a wild Atlantic salmon (Salmo salar) population following introgression by farmed escapees. Heredity, 106, 500-510.

Brantestam, A.K., von Bothmer, R., Dayteg, C., Rashal, I., Tuvesson, S. and Weibull, J., 2007. Genetic diversity changes and relationships in spring barley (Hordeum vulgare $\mathrm{L}$.) germplasm of Nordic and Baltic areas as shown by SSR markers. Genetic Resources and Crop Evolution, 54, 749-758.

Brunner, P.C., Douglas, M.R., Osinov, A., Wilson, C.C. and Bernatchez, L., 2001. Holarctic phylogeography of Arctic charr (Salvelinus alpinus L.) inferred from mitochondrial DNA sequences. Evolution, 55, 573-586.

Ceccarelli, S, Grando, S., Maatougui, M., Michael, M., Slash, M., Haghparast, R., Rahmanian, M., Taheri, A., Al-Yassin, A., Benbelkacem, A., Labdi, M., Mimoun, H. and Nachit, M., 2010. Plant breeding and climate changes. Journal of Agricultural Science, 148, 627-637.

Christensen, O.B, Goodess, C.M., Harris, I. and Watkiss, P., 2011. European and Global Climate Change Projections: Discussion of Climate Change Model Outputs, Scenarios and Uncertainty in the EC RTD ClimateCost Project. In: P. Watkiss, ed. 2011. The ClimateCost Project. Final Report. Volume 1: Europe. Stockholm, Sweden: Stockholm Environment Institute. ISBN 978-91-86125-35-6.

Cornuet, J.-M., Piry, S., Luikart, G., Estoup, A. and Solignac, M., 1999. New methods employing multilocus genotypes to select or exclude populations as origins of individuals. Genetics, 153, 1989-2000.

Crête-Lafrenière, A., Weir, L.K. and Bernatchez, L., 2012. Framing the Salmonidae family phylogenetic portrait: a more complete picture from increased taxon sampling. PLoS ONE, 7(10), e46662.

D’Amen, M., Zimmermann, N.E. and Pearman, P.B., 2013. Conservation of phylogeographic lineages under climate change. Global Ecology and Biogeography, 22, 93-104.

Daugstad, K., 2013. Genetiske ressursar i engvekstene. Bevaring av artsfattige enger (kunstmarkseng) Bioforsk Report. Vol 6, Nr. X.

DeWoody, J.A., and Avise, J.C., 2000. Microsatellite variation in marine, freshwater and anadromous fishes compared with other animals. Journal of Fish Biology, 56, 461-473.

Dillane, E., McGinnity, P., Coughlan, J.P., Cross, M.C., Eyto, E.D., Kenchington, E., Prodöhl, P. and Cross, T.F., 2008. Demographics and landscape features determine intrariver population structure in Atlantic salmon (Salmo salar L.): the case of the River Moy in Ireland. Molecular Ecology, 17, 4786-4800.

Estoup, A., Rousset, F., Michalakis, Y., Cornuet, J.-M., Adriamanga, M. and Guyomard, R., 1998. Comparative analysis of microsatellite and allozyme markers: a case study investigating microgeographic differentiation in brown trout (Salmo trutta). Molecular Ecology, 7, 339-353. 
FAOSTAT, 2012. Food and Agriculture Organization of the United Nations. Available at: http://faostat3.fao.org/home/index.html\#HOME

Finnegan, A.K., Griffiths, A.M., King, R.A., Machado-Schiafno, G., Porcher, J.-P., GarciaVazquez, E., Bright, D. and Stevens, J.R., 2013. Use of multiple markers demonstrates a cryptic western refugium and postglacial colonisation routes of Atlantic salmon (Salmo salar L.) in northwest Europe. Heredity, 111, 34-43.

Fjellheim, S. and Rognli, O.A., 2005. Molecular diversity of local Norwegian meadow fescue (Festuca pratensis Huds.) populations and Nordic cultivars - consequences for management and utilisation. Theor. Appl. Genet., 111, 640 - 650.

Foley, J.A., Ramankutty, N., Brauman, L.A., Cassidy, E.S., Gerber, J.S., Johnston, M., Mueller, N.D., O’Connell, C., Ray, D.K., West, P.C., Balzer, C., Bennett, E.M., Carpenter, S.R., Hill, J., Monfreda, C., Polasky, S., Rockström, J., Sheehan, J., Siebert, S., Tilman, D. and Zaks, D.P.M., 2011. Solutions for a cultivated planet. Nature, 478, 337-342.

Fraser, D.J. and Bernatchez, L., 2001. Adaptive evolutionary conservation: towards a unified concept for defining conservation units. Molecular Ecology, 10, 2741-2752.

Fraser, D.J., Weir, L.K., Bernatchez, L., Hansen, M.M. and Taylor, E.B., 2011. Extent and scale of local adaptation in salmonid fishes: review and meta-analysis. Heredity, $106,404-420$.

Garant, D., Dodson, J.J. and Bernatchez, L., 2000. Ecological determinants and temporal stability of the within-river population structure in Atlantic salmon (Salmo salar L.). Molecular Ecology, 9, 615-628.

Gíslason, D., Ferguson, M.M., Skúlason, S. and Snorrason, S.S., 1999. Rapid and coupled phenotypic and genetic divergence in Icelandic Arctic char (Salvelinus alpinus). Canadian Journal of Fisheries and Aquatic Sciences, 56, 2229-2234.

Glover, K.A., Quintela, M., Wennevik, V., Besnier, F., Sørvik, A.G.E. and Skaala, Ø., 2012. Three decades of farmed escapees in the wild: a spatio-temporal analysis of Atlantic salmon population genetic structure throughout Norway. PLoS ONE, 7(8), e43129.

Goodman, R.M., Hauptli, H., Crossway, A. and Knauf, V.C., 1987. Gene transfer in crop improvement. Science, 236, 48-54.

Gudmundsson, L.A., Gudjónsson, S., Marteinsdóttir, G., Scarnecchia, D.L., Daníelsdóttir, A.K. and Pampoulie, C., 2013. Spatio-temporal effects of stray hatchery-reared Atlantic salmon Salmo salar on population genetic structure within a $21 \mathrm{~km}$-long Icelandic river system. Conservation Genetics, 14, 1217-1231.

Gyllensten, U., 1985. The genetic structure of fish: differences in the intraspecific distribution of biochemical genetic variation between marine, anadromous, and freshwater species. Journal of Fish Biology, 26, 691-699.

Hakala, K., Jauhiainen, L., Himanen, S.J., Rötter, R., Salo, T. and Kahiluoto, H., 2012. Sensitivity of barley varieties to weather in Finland. Journal of Agricultural Science, 150, 145-160.

Hansen, M.M., Fraser, D.J., Meier, K. and Mensberg, K.-L.D., 2009. Sixty years of anthropogenic pressure: a spatio-temporal genetic analysis of brown trout populations subject to stocking and population declines. Molecular Ecology, 18, 2549-2562.

Harlan, J.R., 1976. Barley. In: N. W. Simmonds, ed. 1976. Evolution of Crop Plants. London, UK: Longman.

Hein, C.L., Öhlund, G. and Englund, G., 2011. Future distribution of Arctic char Salvelinus alpinus in Sweden under climate change: effects of temperature, lake size and species interactions. Ambio, 41, 303-312.

Hindar, K., Ryman, N. and Ståhl, G., 1986. Genetic differentiation among local populations and morphotypes of Arctic charr, Salvelinus alpinus. Biological Journal of the Linnean Society, 27, 269-285. 
Horreo, J.L., Machado-Schiaffino, G., Ayllon, F., Griffiths, A.M., Bright, D., Stevens, J.R. and Garcia-Vazquez, E., 2011. Impact of climate change and human-mediated introgression on southern European Atlantic salmon populations. Global Change Biology, $17,1778-1787$.

Hysing, S.-C., Säll, T., Nybom, H., Liljeroth, E., Merker, A., Orford, S. and Koebner, R.M.D., 2008. Temporal diversity changes among 198 Nordic bread wheat landraces and cultivars detected by retrotransposon-based S-SAP analysis. Plant Genetic Resources, 6, 113-125.

Høst, 0., 1982. Danske kulturplanter. Frederiksberg, Denmark: DSR Forlag.

IPCC, 2013. Summary for Policymakers. In: Climate Change 2013: The Physical Science Basis. Contribution of Working Group I to the Fifth Assessment Report of the Intergovernmental Panel on Climate Change. T.F Stocker, D. Qin, G.-K. Plattner, M. Tignor, S. K. Allen, J. Boschung, A. Nauels, Y. Xia, V. Bex and P.M. Midgley, eds. Cambridge, UK, and New York, NY, USA: Cambridge University Press.

Klemetsen, A., 2010. The charr problem revisited: exceptional phenotypic plasticity promotes ecological speciation in postglacial lakes. Freshwater Reviews, 3, 49-74.

Klemetsen, A., Amundsen, P.-A., Dempson, J.B., Jonsson, B., Jonsson, N., O'Connell, M.F. and Mortensen, E., 2003. Atlantic salmon Salmo salar L., brown trout Salmo trutta L. and Arctic charr Salvelinus alpinus (L.): a review of aspects of their life histories. Ecology of Freshwater Fish, 12, 1-59.

Laikre, L., Palmé, A., Josefsson, M., Utter, F. and Ryman, N., 2006. Release of alien populations in Sweden. Ambio, 35, 255-261.

Larter, E.N., 1976. Triticale. In: N.W. Simmonds, ed. 1976. Evolution of Crop Plants. London, UK: Longman.

Lillehammer, M., Meuwissen, T.H.E. and Sonesson, A.K., 2011. A comparison of dairy cattle breeding designs that use genomic selection. Journal of Dairy Science, 94, 493-500.

Lobell, D.B. and Field, C.B., 2007. Global scale climate-crop yield relationships and the impacts of recent warming. Environmental Research Letters, 2, 1-7.

Long, S.P., Ainsworth, E.A., Leakey, A.D.B., Nösberger, J. and Ort, D.R., 2006. Food for Thought: Lower-Than-Expected Crop Yield Stimulation with Rising $\mathrm{CO}_{2}$ Concentrations. Science, 312, 1918-1921.

Luo, Q., Bellotti, W., Williams, M. and Wang, E., 2009. Adaptation to climate change of wheat growing in South Australia: analysis of management and breeding strategies. Agriculture Ecosystems and Environment, 129, 261-267. doi:10.1016/j.agee.2008.09.010

Manifesto, M.M., Schlatter, A.R., Hopp, H.E., Suárez, E.Y. and Dubcovsky, J., 2001. Quantitative evaluation of genetic diversity in wheat germplasm using molecular markers. Crop Science, 41, 682-690.

McGinnity, P., Prodöhl, P., Ferguson, A., Hynes, R., Maoiléidigh, N.Ó., Baker, N., Cotter, D., O'Hea, B., Cooke, D., Rogan, G., Taggart, J. and Cross, T., 2003. Fitness reduction and potential extinction of wild populations of Atlantic salmon, Salmo salar, as a result of interactions with escaped farm salmon. Proceedings of the Royal Society of London, Series B, 270, 2443-2450.

McKeown, N.J., Hynes, R.A., Duguid, R.A., Ferguson, A. and Prodöhl, P.A., 2010. Phylogeographic structure of brown trout Salmo trutta in Britain and Ireland: glacial refugia, postglacial colonization and origins of sympatric populations. Journal of Fish Biology, 76, 319-347.

Meuwissen, T.H.E., 1997. Maximizing the response of selection with a predefined rate of inbreeding. Journal of Animal Science, 75, 934-940.

Meuwissen, T. H. E., Hayes, B. J. and Goddard, M. E., 2001. Prediction of total genetic value using genome-wide dense marker maps. Genetics, 157, 1819-1829. 
Nielsen, E.E. and Hansen, M.M., 2008. Waking the dead: the value of population genetic analyses of historical samples. Fish and Fisheries, 9, 450-461.

O'Connel, M. and Wright, J.M., 1997. Microsatellite DNA in fishes. Reviews in Fish Biology and Fisheries, 7, 331-363.

Ortiz, R., Nurminiemi, M., Madsen, S., Rognli, O.A. and Bjørnstad, Å., 2002. Cultivar diversity in Nordic spring barley breeding (1930-1991). Euphytica, 123, 111-119.

Ozerov, M.Y., Veselov, A.E., Lumme, J. and Primmer, C.R., 2012. "Riverscape" genetics: river characteristics influence the genetic structure and diversity of anadromous and freshwater Atlantic salmon (Salmo salar) populations in northwest Russia. Canadian Journal of Fisheries and Aquatic Sciences, 69, 1947-1958.

Parikka, P., Hakala, K. and Tiilikkala, K., 2012. Expected shifts in Fusarium species' composition on cereal grain in Northern Europe due to climatic change. Food Additives \& Contaminants: Part A, 29 (10), 1543-1555.

Parrish, D.L., Behnke, R.J., Gephard, S.R., McCormick, S.D. and Reeves, G.H., 1998. Why aren't there more Atlantic salmon (Salmo salar)? Canadian Journal of Fisheries and Aquatic Sciences, 55, 281-287.

Perrier, C., Guyomard, R., Bagliniere, J.-L., Nikolic, N. and Evanno, G., 2013. Changes in the genetic structure of Atlantic salmon populations over four decades reveal substantial impacts of stocking and potential resiliency. Ecology and Evolution, 3, 2334-2349.

Pleijel, H., Skärby, L., Ojanperä, K. and Selldén, G., 1992. Yield and quality of spring barley, Hordeum vulgare L., exposed to different concentrations of ozone in open-top chambers. Agriculture, Ecosystems and Environment, 38, 21-29.

Poland, J.A. and Rife, T.W., 2012. Genotyping-by-sequencing for plant breeding and genetics. Plant Gen., 5, 92-102.

Primmer, C.R., Veselov, A.J., Zubchenko, A., Poututkin, A., Bakhmet, I. and Koskinen, M.T., 2006. Isolation by distance within a river system: genetic population structuring of Atlantic salmon, Salmo salar, in tributaries of the Varzuga River in northwest Russia. Molecular Ecology, 15, 653-666.

Pritchard, J.K., Stephens, M. and Donnelly, P., 2000. Inference of population structure using multilocus genotype data. Genetics, 155, 945-959.

Rognli, O.A., Fjellheim, S., Pecetti, L. and Boller, B., 2013. Semi-natural grasslands as a source of genetic diversity. Grassland Science in Europe, 18, 303-313.

Rognstad, O. and Steinset, T.A., 2008. Landbruket i Norge 2007. Statistiske analyser/ Statistical analyses 101, Statistisk sentralbyrå.

Sandlund O.T., Gunnarsson, K., Jónasson, P.M., Jonsson, B. , Lindem, T., Magnússon, K.P., Malmquist, H.J., Sigurjónsdóttir, H., Skúlason, S. and Snorrason, S.S., 1992. The arctic charr Salvelinus alpinus in Thingvallavatn. Oikos, 64, 305-351.

Säisä, M., Koljonen, M.-L., Gross, R., Nilsson, J., Tähtinen, J., Koskiniemi, J. and Vasemägi, A., 2005. Population genetic structure and postglacial colonization of Atlantic salmon (Salmo salar) in the Baltic Sea area based on microsatellite DNA variation. Canadian Journal of Fisheries and Aquatic Sciences, 62, 1887-1904.

Ståhl, G., 1987. Genetic population structure of Atlantic salmon. In: N. Ryman and F. Utter, eds. 1987. Population Genetics and Fishery Management. Seattle, Washington: University of Washington Press. pp.121-140.

Taylor, E.B., 1991. A review of local adaptation in Salmonidae, with particular reference to Pacific and Atlantic salmon. Aquaculture, 98, 185-207.

Therkildsen, N.O., Hemmer-Hansen, J., Hedeholm, R.B., Wisz, M.S., Pampoulie, C., Meldrup, D., Bonanomi, S., Retzel, A., Olsen, S.M. and Nielsen, E.E., 2013. Spatiotemporal SNP analysis reveals pronounced biocomplexity at the northern range margin of Atlantic cod Gadus morhua. Evolutionary Applications, 6, 690-705. 
Thorsen, S. M. and Höglind, M., 2010. Modelling cold hardening and dehardening in timothy. Sensitivity analysis and Bayesian model comparison. Agricultural and Forest Meteorology, 150, 1529-1542.

Tilman, D., Fargione, J., Wolff, B., D’Antonio, C., Dobson, S., Howarth, R., Schindler, D., Schlesinger, W.H., Simberloff, D. and Swackhamer, D., 2001. Forecasting agriculturally driven global environmental change. Science, 292, 281-284.

Tilman, D., Cassman, K.G., Matson, P.A., Naylor, R. and Polasky, S., 2002. Agricultural sustainability and intensive production practices. Nature, 418, 671-677.

Trnka M., Brázdil R., Olesen J. E., Eitzinger J., Zahradníček P., Kocmánková E., Dobrovolný P., Štěpánek P., Možný M., Bartošová L., Hlavinka P., Semerádová D., Valášek H., Havlíček M., Horáková V., Fischer M. and Žalud Z., 2012. Could the changes in regional crop yields be a pointer of climatic change? Agricultural and Forest Meteorology, 166-167, 62-71.

Vähä, J.-P., Erkinaro, J., Niemelä, E. and Primmer, C.R., 2008. Temporally stable genetic structure and low migration in an Atlantic salmon population complex: implications for conservation and management. Evolutionary Applications, 1, 137-154.

Verspoor, E., Beardmore, J.A., Consuegra, S., García de Leániz, C., Hindar, K., Jordan, W.C., Koljonen, M.-L., Mahkrov, A.A., Paaver, T., Sánchez, J.A., Skaala, Ø., Titov, S. and Cross, T.F., 2005. Population structure in the Atlantic salmon: insights from 40 years of research into genetic protein variation. Journal of Fish Biology, 67, 3-54.

Verspoor, E., Knox, D., Greer, R. and Hammar, J., 2010. Mitochondrial DNA variation in Arctic charr (Salvelinus alpinus (L.)) morphs from Loch Rannoch, Scotland: evidence for allopatric and peripatric divergence. Hydrobiologia, 650, 117-131.

Waples, R.S., 1995. Evolutionarily significant units and the conservation of biological diversity under the Endangered Species Act. American Fisheries Society Symposium, $17,8-27$.

Wilkinson, S., Mills, G., Illidge, R. and Davies, W.I., 2012. How is ozone pollution reducing our food supply? Journal of Experimental Botany, 63, 527-536.

Ødegård, J., Sonesson, A.K., Hossein, Y.M. and Meuwissen, T., 2009. Introgression of a major QTL from an inferior into a superior population using genomic selection. Genetics, Selection, Evolution 41, 38.

Østergaard, S., Hansen, M.M., Loeschcke, V. and Nielsen, E.E., 2003. Long-term temporal changes of genetic composition in brown trout (Salmo trutta L.) populations inhabiting an unstable environment. Molecular Ecology, 12, 3123-3135. 



\section{Bioeconomy}

The bioeconomy may be defined as an economy in which the basic building blocks for materials, chemicals and energy are derived from renewable biological resources (McCormic and Kettler 2013). Traditional bioeconomy literature emerged out of a concern about the use of nonrenewable resources and an increasing population, and emphasises increased effectiveness in resource use, i.e. producing more per input.

Several studies look into potential growth in the renewable resource sectors, with emphasis on economic potential and possible growth in employment. Biological resources are also of particular interest as potentials for reducing GHG emissions through accumulation of carbon in biomass and as substitutes for fossil energy.

\subsection{Status}

According to the European Commission (2012), the European bioeconomy has an estimated annual turnover of about EUR 2 trillion and employs more than 22 million people, or approximately $9 \%$ of the total EU workforce (see Table 10.1).

\begin{tabular}{lrr}
$\begin{array}{l}\text { Table 10.1: The bioeconomy of the European Union } \\
\text { Annual turnover in EUR billion }\end{array}$ & $\begin{array}{r}\text { Employment: } \mathbf{1 0 0 0} \\
\text { Food }\end{array}$ \\
Agriculture & 965 & 4,400 \\
Paper/pulp & 381 & 12,000 \\
Forestry/wood industries & 375 & 1,800 \\
Fisheries and aquaculture & 269 & 3,000 \\
Bio-chemicals and plastic & 32 & 500 \\
Enzymes & 50 & 150 \\
Biofuels & 1 & 5 \\
Total & 6 & 150 \\
\hline
\end{tabular}

Source: European Commission (2012).

\subsubsection{Employment}

More than half the employment in the bioeconomic activities listed in Table 10.1 is associated with agriculture. Employment in the agriculture sector has decreased steadily over the past century, along with employ- 
ment in other primary sectors, e.g. forestry and fisheries. For many years, structural development moved towards fewer and larger holdings, and thus less labour-intensive production. For example, the share of employment in the agriculture sector was about 30\% in Norway in 1950. Since then, employment in the sector has steadily decreased in all the Nordic countries, to a level of approximately $3-11 \%$ in 1990, with a further decline to the present level of 2-6\% in 2012 (see Figure 10.1). Employment in the forestry sector is most extensive in Sweden and Finland, with $3.6 \%$ and $2.0 \%$ respectively (Portin et al. 2013). The declining trend in agriculture applies to fisheries and forestry as well. Alongside the decline in the primary industries, new industries such as the aquaculture industry have emerged.

Figure 10.1: Agriculture, forestry and fisheries, percentage of total employment

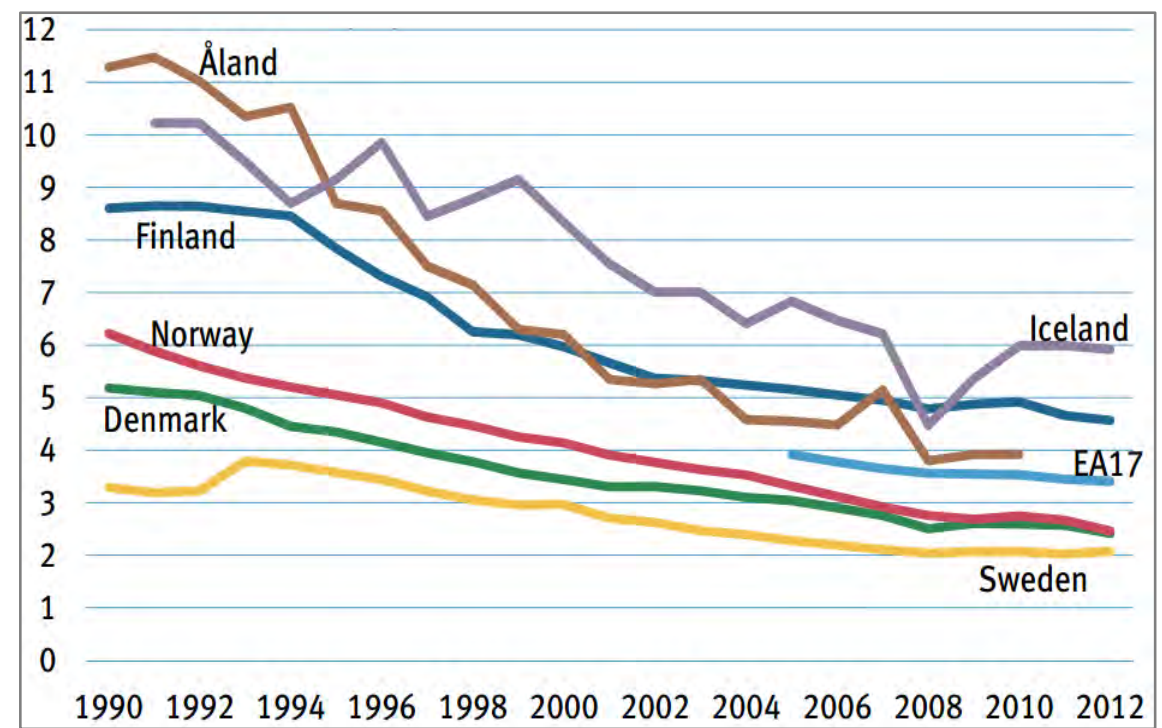

Source: Norden (2013)

\subsubsection{Economic impacts}

The turnover listed in Table 10.1 amounts to about $20 \%$ of GDP in the EU. Looking at the Nordic countries and the forestry sector alone, the share amounts to 5\% in Finland and 3.4\% in Sweden. With the exception of Denmark, the shares are lower for the agricultural sector, ranging from roughly $0.4-1.6 \%$ (see Table 10.2). Due to natural conditions, agriculture production constitutes a significantly lower share in the Nordic countries, with the highest share in Denmark. Turnover has been quite 
stable over the past decade, but due to higher growth in other sectors, the share of total GDP shows an overall decreasing trend over time.

\begin{tabular}{|c|c|c|c|c|}
\hline & Denmark & Finland & Norway & Sweden \\
\hline \multicolumn{5}{|c|}{ Agriculture } \\
\hline 2004 & 1.6 & 1.0 & 0.8 & 0.6 \\
\hline 2012 & 1.6 & 0.9 & 0.6 & 0.4 \\
\hline Forestry & 0.8 & 5.0 & 1.0 & 3.4 \\
\hline
\end{tabular}

${ }^{1}$ The value of produced goods and services in the sector.

Source: Eurostat database (Agriculture), Portin et al. (2013) (Forestry).

Although bioeconomy production is relatively limited compared to the rest of the economy, products from the primary industries constitute a significant share of exports from the Nordic countries. For example, twothirds of all Danish agriculture products are exported, and food and live animal products amount to $18 \%$ of total exports (Norden 2013). Forestry and the wood and paper industries are particularly important exporters in Sweden, Finland and Norway. The fisheries industry plays a major role in Norway, and fisheries is by far the dominant industry in Iceland, the Faroe Islands and Greenland, with respect to both production and exports (Norden 2013).

Table 10.3: Export of food, live animals, animal and vegetable oils, fats and waxes, in percentage of total exports

\begin{tabular}{rrrrr} 
Denmark & Finland & Iceland & Norway & Sweden \\
17.1 & 2.3 & 42.2 & 5.8 & 4.1 \\
0.7 & & 2.3 & 0.2 & 0.2 \\
17.8 & 2.3 & 44.5 & 6.0 & 4.3 \\
\hline
\end{tabular}

Source: Nordic Statistical Yearbook 2013.

\section{Forestry}

Sweden has the largest proportion of forests in the Nordic region, with 46\%, followed by Finland with 36\% and Norway with 17\% (see Figure 7.1 in Chapter 7).

This is reflected in the considerable production of wood for industrial use, particularly in Finland and Sweden. For example, together the two countries account for $12.8 \%$ of world production of wood pulp, which is one of their major export items (see Table 10.4). 


\begin{tabular}{l|crrrr} 
Table 10.4: Production of forest products, in percentage of world production, $\mathbf{2 0 1 1}$ & \\
& Denmark & Finland & Norway & Sweden & Total \\
Industrial round-wood & 0.1 & 2.9 & 0.5 & 4.2 & 7.7 \\
Saw logs and veneer logs & 0.1 & 2.3 & 0.5 & 4.0 & 6.9 \\
Wood-based panels & 0.2 & 0.5 & 0.2 & 0.2 & 1.1 \\
Wood pulp & - & 6.0 & 1.1 & 6.8 & 13.9 \\
Paper and paperboard & 0.1 & 2.8 & 0.4 & 2.9 & 6.2 \\
\hline
\end{tabular}

Source: Norden (2013)

\section{Fisheries}

The three main Nordic fishing nations are Norway, Iceland and Denmark (see Figure 10.2). Atlantic cod (Gadus morhua) and Atlantic herring (Clupea harengus), primarily used for human consumption, dominate the catch. Fish farming is especially important in Norway, where the production of salmon is predominant.

Figure 10.2: Value (EUR million) of commercial catches of marine fish in 2012

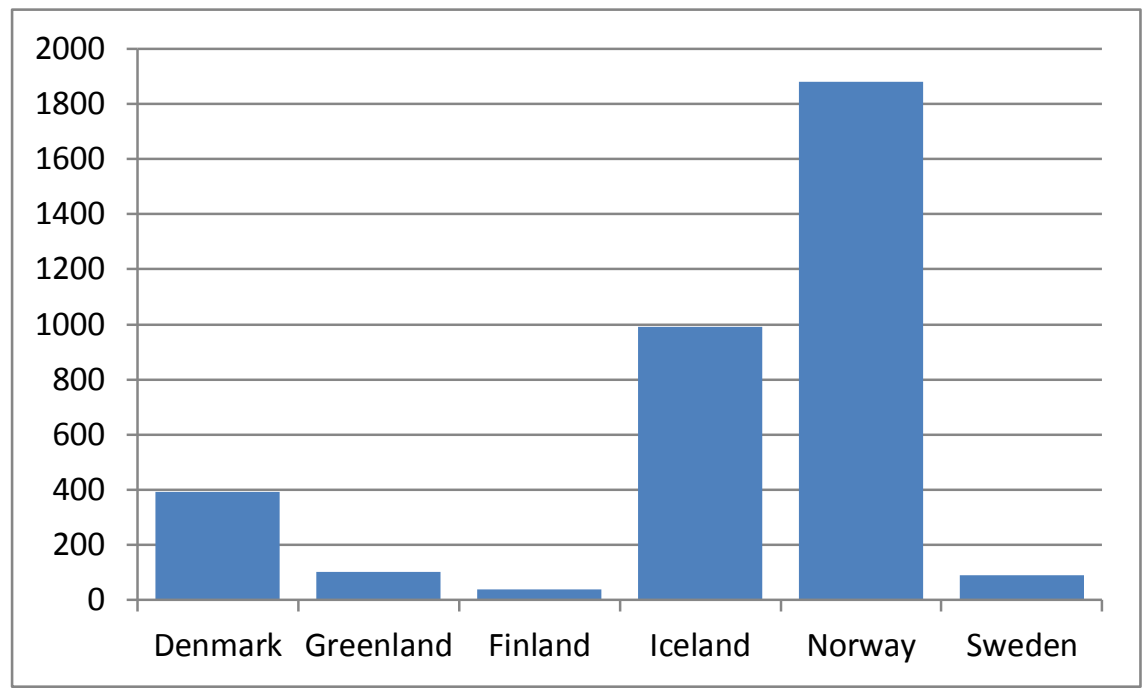

Source: Norden (2013).

The value of catches, and thus the economic importance of fishing, has increased over the past decade, particularly in Iceland and Norway (see Figure 10.3). 
Figure 10.3: Value of catches of fish, index, 2,000=100

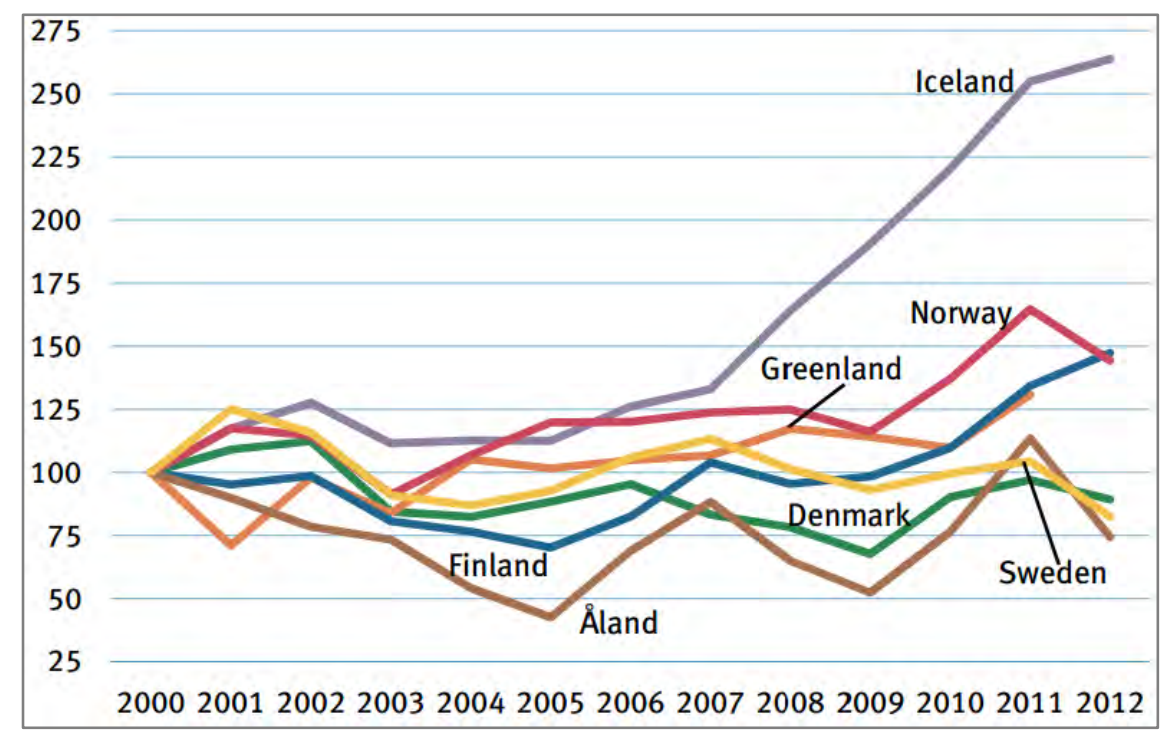

Source: Nordic Statistical Yearbook 2013.

\subsection{Bioeconomy and carbon emissions}

Renewable resources play an important role in the abatement of GHG emissions. First, net growth in biological mass contributes to a net uptake of $\mathrm{CO}_{2}$ from the atmosphere. A carbon sink is a system that accumulates and stores atmospheric carbon. Forests play an important role in the global carbon cycle and climate change mitigation. They absorb atmospheric carbon through photosynthesis and sequester it in living and dead biomass and soil, thereby providing natural storage of carbon. Over a long period of time the forests have accumulated more $\mathrm{CO}_{2}$ than they have released. Harvested wood products are other sources of carbon accumulation.

Renewable energy resources are another key source of carbon abatement. Use of bioenergy can help to reduce the use of fossil energy and thus emissions of $\mathrm{CO}_{2}$. This will require the substitution of resources through new biological growth and carbon uptake from the atmosphere. Burning wood and pellets and waste incineration are examples of bioenergy.

In all the Nordic countries, especially Finland, Sweden and Norway, the total growing and biomass stocks have increased over the past six to seven decades. The total biomass stock is expected to grow and the net annual increment is expected to remain positive in coming decades as well (see Figure 7.4 in Chapter 7) (Portin et al. 2013). These constitute 
important mitigation potentials as carbon sinks and substitutes for fossil energy, as well as dead organic matter and soil.

\subsubsection{Carbon sinks}

Carbon sinks already compensate for $43 \%$ of GHG emissions in the Nordic countries (see Table 10.5). The variation is large between countries, from $9 \%$ in Denmark to $66 \%$ in Norway.

\begin{tabular}{lrrrrrr} 
Table 10.5: Carbon sinks and emissions in & 2010, million tonnes $\mathbf{C O}_{\mathbf{2}}$-equivalents \\
& Denmark & Finland & Iceland & Norway & Sweden & Total \\
\hline Forest carbon sink & 5.7 & 32.7 & 0.3 & 35.9 & 38.1 & 112.6 \\
GHG emissions & 62.6 & 74.6 & 5.3 & 54.3 & 66.3 & 263.0 \\
\% carbon sink & $9 \%$ & $44 \%$ & $5 \%$ & $66 \%$ & $57 \%$ & $43 \%$
\end{tabular}

Source: Portin et al. (2013)

The expected growth in forest biomass and dead biomass and soil implies a significant increase in carbon storage. The increasing trend in net removal of $\mathrm{CO}_{2}$ by forests from 1998 to the present is expected to continue, reaching about 140 million tonnes by 2020 (see Figure 7.5 in Chapter 7) (Portin et al. 2013). Forest management practices such as fertilisation, optimised thinning and lengthening rotation are clearly having a positive effect. By 2020, net removal in Finland, Norway and Sweden is projected to be about $75 \%$ of the 2011 GHG emission level in the three countries.

Use of wood in construction and products is another source of carbon storage. Substituting wood for more energy-intensive materials such as concrete and steel may also help to prevent GHG emissions. Wood is widely used for construction, energy production and products such as furniture, paper and packaging. The climate benefits of wood use are highly case-specific and depend mainly on the carbon storage capacity of the product, its full life cycle and the properties of the material that has been substituted (Portin et al. 2013). Carbon storage in wood in the Nordic region is currently estimated at about 7 million tonnes of $\mathrm{CO}_{2}$, or approximately $4 \%$ of GHG emissions in the region. 
Figure 10.4: Net removal of $\mathrm{CO}_{2}$ by harvested wood products in the Nordic countries, million tonnes of $\mathrm{CO}_{2}$

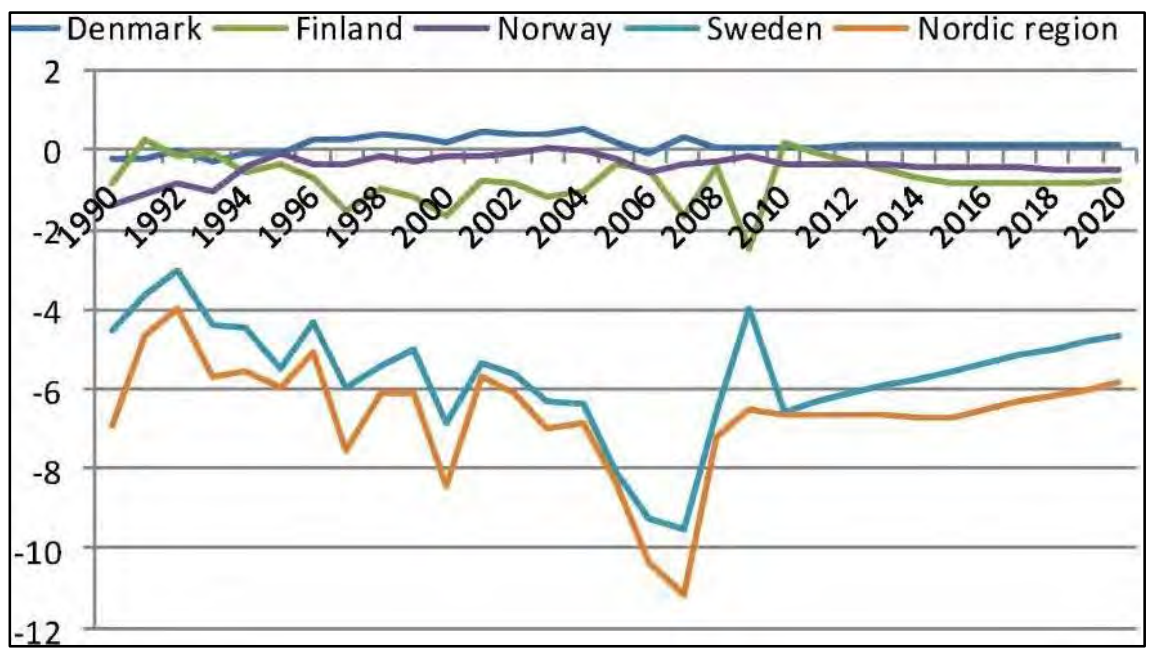

Source: Portin et al. (2013).

\subsubsection{Biomass and energy}

The share of renewable energy production in the Nordic countries is about $16 \%$, of which about $8 \%$ is based on biomass and waste (see Table 10.6). The Norwegian petroleum sector dominates energy production. The main biomass energy producers are Finland and Sweden, where the shares are $47 \%$ and $30 \%$ respectively.

\begin{tabular}{lrrrrrr} 
Table 10.6: Production of primary energy in TWh, & $\mathbf{2 0 1 1}$ (2006 for Iceland) & & \\
& Denmark & Finland & Iceland & Norway & Sweden & Total \\
Biomass and waste & 25 & 93 & 0 & 17 & 111 & 246 \\
Other renewable & 10 & 13 & 38 & 122 & 73 & 256 \\
Fossil fuels & 204 & 90 & 0 & 2179 & 184 & 2657 \\
Share biomass and waste & $10 \%$ & $47 \%$ & $0 \%$ & $1 \%$ & $30 \%$ & $8 \%$ \\
Share renewable & $15 \%$ & $54 \%$ & $100 \%$ & $6 \%$ & $50 \%$ & $16 \%$ \\
\hline
\end{tabular}

Source: EU statistical database

In 2011, energy production based on biomass and waste amounted to about 250 TWh in the Nordic countries. The potential is significantly higher. Econ (2008) estimates the total biomass potential at about 360 TWh for the Nordic countries (see Table 10.7). Thus, the physical potential for future bioenergy production may be up to $50 \%$ higher than present production. 


\begin{tabular}{lrrrrr} 
Table 10.7: Biomass potentials for energy purposes, TWh & & & \\
& Denmark & Finland & Norway & Sweden & Total \\
Wood and timber & 11 & 38 & 32 & 21 & 102 \\
Forest industry by-products & 0 & 19 & 0 & 88 & 108 \\
Grass and straw & 15 & 7 & 5 & 0 & 27 \\
Black liquor & 0 & 44 & 0 & 39 & 84 \\
Biogas & 11 & 3 & 4 & 0 & 18 \\
Organic waste & 8 & 0 & 3 & 7 & 19 \\
Other & 0 & 0 & 0 & 6 & 6 \\
Total & 46 & 111 & 44 & 162 & 363 \\
\hline
\end{tabular}

However, this does not imply a corresponding potential for GHG reductions. An increase in bioenergy production will partly increase total energy production as energy prices drop, and partly substitute other energy production. The total effect will rely on price responses in the energy markets.

In addition, collecting harvesting residues for bioenergy use has negative effects on growth and carbon stock of forests. Old-growth forests protected by strict conservation are conducive to increasing carbon stock and conserving biodiversity (Portin et al. 2013). Findings from recent literature show that extracting biomass from boreal forests on a permanent basis leads to increased atmospheric carbon concentration compared with a no-harvest scenario (Holtsmark 2012, 2013). In a typical boreal forest, it takes 70-120 years before a stand of trees is mature. A high level of harvest means that the carbon stock in the forest stabilises at a lower level. Therefore, wood harvesting is not carbon neutral.

\subsection{Future prospects}

Bioeconomy initiatives mainly focus on strategies to stimulate growth in production based on biological resources. Typically, the initiatives recommend public funding of investments in research, innovation and skills, support for strategy building and stakeholder engagement, and information campaigns and standards for bio-based products (European Commission 2012). The European Commission's 2012 action plan for the European bioeconomy includes a set of objectives and actions to be taken at the EU and member state levels. The aim is to pave the way for a more innovative, resource efficient and competitive society that reconciles food security with the sustainable use of renewable resources for industrial purposes, while ensuring environmental protection. As a general consequence of the initiatives, production based on biological resources is likely to increase. 
Another approach to the bioeconomy focuses on the potential for mitigation of carbon emissions from the production sectors involved in the bioeconomy. Stricter regulations on fossil energy production would boost economic incentives to exploit this potential to a higher degree. Carbon taxes and emission trading systems increase fossil energy production costs and energy prices. This in turn increases the profitability of bioenergy supply. Demand for bioenergy is also stimulated as fossil-based energy production is reduced due to higher prices. Thus, intensified climate policy stimulates the bioeconomy. Policies to promote carbon sinks are mature compared to economic instruments regulating carbon emissions. Possible future instruments consistent with carbon pricing would imply subsidies to forest owners and for carbon storage in wood. The counterpart would be carbon taxes on wood. Subsidies for carbon sinks would stimulate further growth of the Nordic forests, but would likely have adverse effects on employment in the bioeconomic sector.

Finally, the rapidly growing regional and global population and higher life expectancy are a strong driving force, increasing demand for biobased products in particular and products in general. Increasing scarcity due to the extraction of non-renewable resources also boosts demand for renewable substitutes and biological products.

\subsection{Soy products}

\subsubsection{Soy import, 2009-2011}

Annual gross import of soy products to the five Nordic countries was 2.6 Mt on average for the years 2009-2011. More than 80\% of this import went to Denmark and Norway (see Figure 10.5). 
Figure 10.5: Gross import of soy products to the Nordic countries, average for 2009-2011

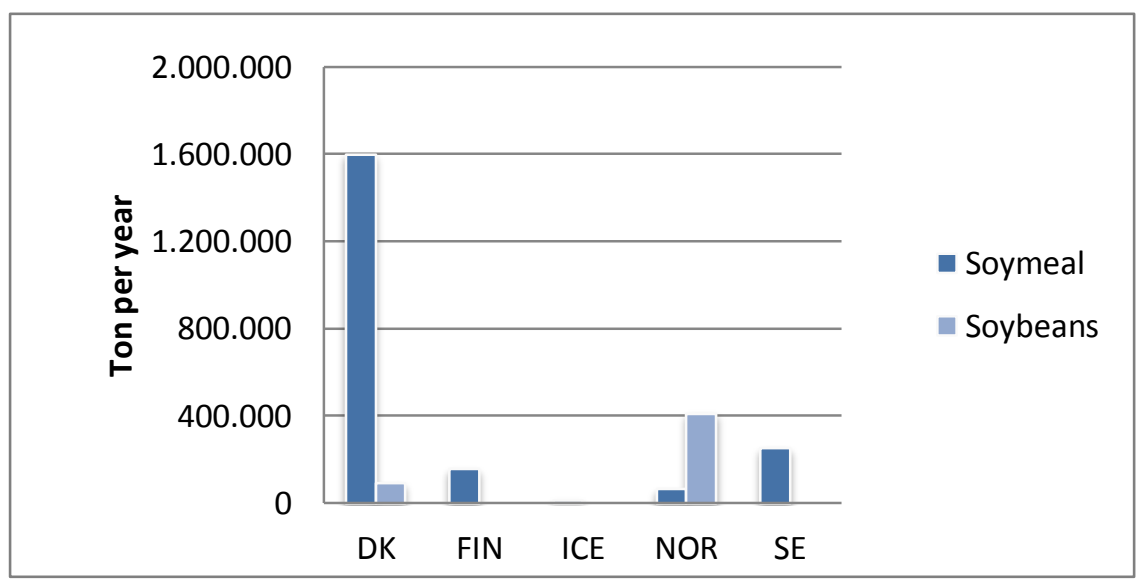

Source: FAOSTAT.

Both Denmark and Norway export soybean products (mostly soymeal). Figure 10.6 shows net import of soybean products to the Nordic countries, where exports are subtracted from gross import. The net import is approximately $2.25 \mathrm{Mt}$ per year.

Figure 10.6: Net import of soy products to the Nordic countries, average for 2009-2011

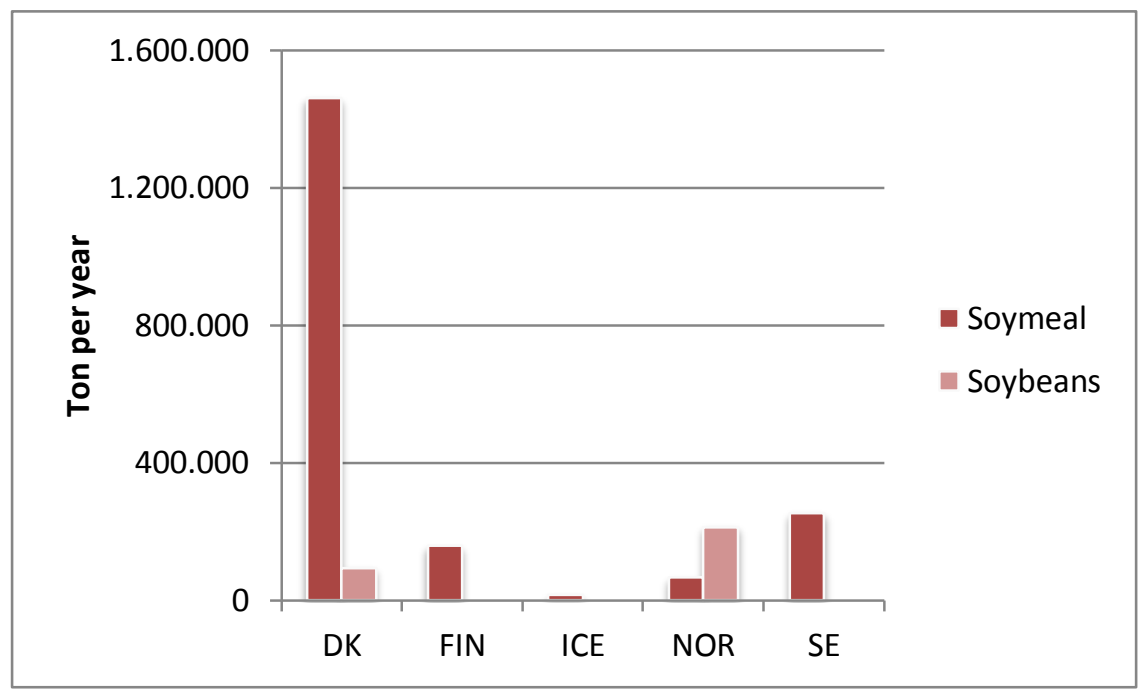

Source: FAOSTAT. 


\subsubsection{Soybean and soymeal yields}

Argentina: 2,500 kg/ha and Brazil 2,830 kg/ha (average over the past four years), assuming average yield for import at 2,600 kg/ha*yr (after deducting for seed). Approximately $79 \%$ of bean is soymeal; yield of soymeal $=2.05 \mathrm{t} / \mathrm{ha}$.

\subsubsection{Area needed for imported soy}

In Alternative 1, there is no allocation; all land is distributed for soymeal: yield $2.05 \mathrm{t} / \mathrm{ha}$. In Alternative 2, there is mass allocation; all products from the soybean share the land burden equally: yield $2.6 \mathrm{t} / \mathrm{ha}$.

\begin{tabular}{|c|c|c|}
\hline & Alternative 1, no allocation & Alternative $\mathbf{2}$, mass allocation \\
\hline $\begin{array}{l}\text { Area in South America for net import of } \\
\text { soy products to the Nordic countries }\end{array}$ & $\begin{array}{l}\text { A little more than } \\
1 \text { million ha/yr }\end{array}$ & $\begin{array}{l}\text { Approximately } \\
870,000 \text { ha/yr }\end{array}$ \\
\hline
\end{tabular}

Calculation of the area for the gross import (see Table 10.8) shows that the area needed is 1.2 million ha and 1 million ha per year for the two alternatives respectively.

\subsection{References}

Econ, 2008. Facts and figures on the use of bioenergy in the Nordic countries, Econ Pöyry-Report no. 54.

European Commission, 2012. Innovating for sustainable growth, A bioeconomy for Europe.

EU statistical database. Available at: http://epp.eurostat.ec.europa.eu/portal/page/ portal/energy/data/main_tables

Holtsmark, B., 2012. Harvesting in boreal forests and the biofuel carbon debt. Climatic Change, 112(2), 415-428.

Holtsmark, B., 2013. Boreal forest management and its effects on atmospheric $\mathrm{CO}_{2}$. Ecological Modelling, 248, 130-134.

McCormic, K. and Kettler, N., 2013. The Bioeconomy in Europe: An Overview. Sustainability, 5, 2589-2608.

Norden, 2013. Nordic Statistical Yearbook 2013, Volume 51. K.M. Haagensen, ed. Statistics Denmark

Portin, A., Barua, S., Clarke, M., Camargo, M., Viding, J. and Pekkanen, M., 2013. The Role of Forests in Climate Change: Nordic Experience. TemaNord 2013:559. 



\title{
11. Reports from the networks
}

\author{
11.1 Network 1: Sustainable primary production in a \\ changing climate
}

The Sustainable primary production in a changing climate network evaluated the potential of using 138 spring barley and 36 oilseed rape accessions (gene bank and breeders' material) as input for breeding future cultivars of these species. The accessions comprised landraces, old and new cultivars as well as breeders' lines that have not yet been released on the market. The accessions analysed were exposed to future climate scenarios in a climate phytotron and in a Free Air Carbon Enrichment (FACE) facility in the field. The experimental treatments comprised elevated temperature, $\mathrm{CO}_{2}$ and $\mathrm{O}_{3}$ as single factors, as well as elevated temperature and $\mathrm{CO}_{2}$ in combination, over the plants' full life cycle. The same accessions were analysed in parallel by breeders, either in the field or in greenhouses, in order to identify resistant genotypes. On the basis of their environmental stability, abiotic and biotic stress tolerance and yield, we identified accessions of both spring barley and oilseed rape with a potential to mitigate effects of the future environmental changes on production.

Even when combined with elevated $\mathrm{CO}_{2}$ of $700 \mathrm{ppm}$, the decrease in production of barley due to temperature is not fully compensated. The conclusion from this part of our experiment is that if business-as-usual behaviour is established, the Nordic region may also experience problems with crop productivity, unless new and better cultivars are bred to cope with climate challenges or new management options are available.

Landraces and old and new cultivars are found among the most stable barley accessions. This indicates that traits providing stability under environmental change are present in some of the Nordic material, and can potentially be transferred in crosses. We recommend that environmental stability is routinely accessed when plant material is screened for potential to mitigate climate change. The results of the network also document that genes providing tolerance to climate changes - elevated temperature, elevated $\mathrm{CO}_{2}$ and $\mathrm{O}_{3}$, alone and in combination - exist in barley. We have identified genes that contribute to environmental stability. These genes should be exploited in the breeding of barley cultivars 
for tomorrow's altered climate. The results were obtained using Genome Wide Association Study (GWAS) methods based on SNP microarrays.

With regard to disease resistance, the barley and oilseed rape accessions also demonstrated resistance to a number of diseases. Resistance to Ramularia, Bipolaris, Fusarium, scald, rust and net blotch was scored in barley, and associations between resistance genes and SNP markers were mapped. In addition, we investigated whether infections caused by three diseases - mildew, Bipolaris and net blotch - would be more common in the future climate. The results indicated that infection frequencies in multifactor treatments could by no means be deduced from single factor treatments. In addition to studies on the infection frequency of specific diseases in future climate scenarios, basic studies were conducted on the gene expression profiles of plants infected under future climatic conditions. This knowledge about expression profiles in new environments may ultimately lead to the development of more resistant plants or new fungicides.

We evaluated the response of oilseed rape to the diseases Verticillium and Phoma and found resistant accessions. We also documented large differences between accessions in their tolerance to abiotic stress (elevated temperature, elevated $\mathrm{CO}_{2}$ ), showing that potential candidates for future breeding were present in the material.

The network also analysed the quality of the barley and oilseed rape in future climate scenarios. The oil content of oilseed rape cultivars will decrease and the fatty acid composition of oilseed rape will change in a future altered environment.

We also performed model-based scenario analysis (QSA/LCA), from which we inferred environmental and management implications of future production. QSA/LCA can deliver estimates of loss of nonrenewable resources, changes in GHG emissions, land-use changes, impacts on natural ecosystems and changes in direct and indirect costs. These scenario QSAs/LCAs are key tools for formulating recommendations and strategies. The input to the QSA comprised our primary data from the phytotron and FACE as well as already published data. In the QSA we evaluated the specific environmental effects of future fungicide and fertiliser application. Fertiliser application was one of the most significant factors affecting the environment. 


\section{Publications:}

Clausen, S.K., Frenck, G., Van Der Linden, L., Mikkelsen, T.N., Lunde, C. and Jørgensen, R.B., 2011. Effects of Single and Multifactor Treatments with Elevated Temperature, $\mathrm{CO}_{2}$ and Ozone on Oilseed Rape and Barley. Journal of Agronomy and Crop Science, 197, 442-453.

Fikadu, R.A., Frenck, G., Van Der Linden, L., Mikkelsen, T.N. and Jørgensen, R.B., 2014 (in press). Can barley (Hordeum vulgare L. s.l.) adapt to fast climate changes? A controlled selection experiment. Genetic Resources and Crop Evolution, doi: 10.1007/s10722-013-0021-1

Frenck, G., Van Der Linden., L., Mikkelsen, T.N., Brix, H. and Jørgensen, R.B., 2011. Increased $\mathrm{CO}_{2}$ does not compensate for negative effects on yield caused by higher temperature and $\mathrm{O}_{3}$ in Brassica napus L. European Journal of Agronomy, 35, 127-134.

Frenck, G., Van Der Linden, L., Mikkelsen, T.N., Brix, J. and Jørgensen, R.B., 2013. Response to multi-generational selection under elevated $\mathrm{CO}_{2}$ in two temperature regimes suggests enhanced carbon assimilation and increased reproductive output in Brassica napus L. Ecology and Evolution, 3, 1163-1172.

\section{Manuscripts in preparation or submitted}

- Abiotic stress tolerance in 138 barley genotypes tested in the future Nordic climate. Submitted.

- Disease resistance in barley in a changing climate.

- Mapping QTLs for abiotic stress tolerance and diseases in barley.

- Tolerance to an extreme heat wave in old and recent barley accessions.

- Protein quality in barley for malting and feed in a changing climate.

- Oil quantity and quality in oilseed rape grown in a changing climate.

- Phosphorous, Ion, and Zink in barley cultivated in future climate scenarios.

- Life cycle assessment of the future barley production with focus on environmental sustainability.

\subsection{Network 2: Forest Soil Carbon Sink Nordic Network}

\subsubsection{Importance of soil organic carbon}

Forests cover $60 \%$ of the land area in the five Nordic countries. These forests store massive amounts of carbon (C) and $50-80 \%$ of the $\mathrm{C}$ is stored belowground in soil organic matter. The trees sequester $\mathrm{CO}_{2}$ from the atmosphere by photosynthesis to form biomass $\mathrm{C}$, which is then in part released again by respiration, decomposition and burning of prod- 
ucts. The ultimate long-term storage of the remaining $\mathrm{C}$ is in the soil. To mitigate climate change, it is important to protect and possibly enhance the storage of $\mathrm{C}$ in soil organic matter. It is generally agreed that forest soils are currently sinks for $\mathrm{C}$, but the rate is uncertain. Management changes (e.g. increased extraction of bioenergy) or climate warming may reduce the soil $\mathrm{C}$ sink or even turn forest soils into a source of $\mathrm{CO}_{2}$.

The Forest Soil C-sink Nordic Network was formed to study the C stocks in soil organic matter and their changes in response to management and environmental drivers. The network had participants from Denmark, Iceland, Latvia, Norway and Sweden. We worked by synthesising data and information on soil C stocks, with a focus on the Nordic and Baltic countries, and discussed connected national process studies and case studies. There was a special opportunity in Iceland to establish a unique soil warming experiment (ForHot) in a small forest where displacement of geothermal heating by an earthquake created a temperature gradient. Soil C data from this experiment is currently under analysis. The following provides a report on the influence of tree species, increased harvesting intensity, nitrogen deposition and afforestation on soil C stocks. The information obtained is relevant for reporting under the Kyoto Protocol Articles Nos. 3.3 (afforestation, reforestation and deforestation) and 3.4 (forest management). There are several clearly defined requirements for Kyoto reporting under these articles that require country specific and scientifically approved functions and data.

\subsubsection{Influence of tree species}

We synthesised the current knowledge of tree species effects on soil C stocks. There was evidence of consistent tree species effects on soil C stocks in forest floors, but effects were less clear in mineral soils. Proportional differences in forest floor and mineral soil C stocks among tree species suggested that C stocks can be increased by $200-500 \%$ in forest floors (with conifers building the largest forest floors) and by $40-50 \%$ in top mineral soil by tree species change. However, these proportional differences between forest floors and mineral soils are not always additive: the $\mathrm{C}$ distribution between forest floor and mineral soil rather than the total $\mathrm{C}$ stock tends to differ among tree species. A common garden study with four species at eight sites in Denmark revealed consistently larger $\mathrm{C}$ stocks under conifers than under broadleaves both in the forest floor and in the mineral soil 40 years after planting. Total soil C stocks increased consistently in the order oak $<$ beech $<<$ Norway spruce, larch along the soil texture gradient of the sites. This suggests that some spe- 
cies may be better engineers for sequestration of $\mathrm{C}$ in stable form in mineral soil, but it is unclear whether the key mechanism is root litter input or macro-fauna (e.g. earthworm) activity. The importance of earthworm and ant activity for pine, spruce, deciduous and alder forests in comparison with grasslands was illustrated in a study from southeastern Sweden. For the top $20 \mathrm{~cm}$ of soil, the estimated soil turnover (i.e. the time in which all soil has been processed) by earthworm and ants was 50-500 years depending on ecosystem type and earthworm communities. For targeted use of tree species to sequester soil C, we must identify the processes related to $\mathrm{C}$ input and output, particularly belowground, that control $\mathrm{C}$ stock differences. We also need more information on forms and stability of $\mathrm{C}$ along with bulk $\mathrm{C}$ stocks to assess whether certain broadleaves store $\mathrm{C}$ in a more stable form.

\subsubsection{Effects of increased biomass harvest}

We summarised the literature concerning the effect of harvesting on soil carbon stocks and flows to evaluate the evidence of significant losses increasing with biomass removal. Although model studies suggest reductions in soil carbon stocks when more $\mathrm{C}$ is removed in products, the empirical evidence was less clear. Some studies did report significant reductions, while others showed no difference. Better reestablishment, enhanced ground flora (gaining $\mathrm{C}$ ) or indirect effects through microclimatic changes (reducing decomposition) after increased biomass harvest may compensate for $\mathrm{C}$ removal. There is not enough information available at present to draw firm conclusions about the long-term impact of intensified forest harvesting on these $\mathrm{C}$ cycling processes in Nordic soils. This has sparked a new meta-analysis project on data from Nordic forests. Properly conducted long-term experiments would enable us to clarify the relative importance of different harvesting practices on the soil carbon stores, and the conditions under which the size of the removals becomes critical. Both new experiments and existing long-term experiments are therefore very important.

\subsubsection{Effect of elevated $\mathbf{N}$ deposition}

The extent to which elevated $\mathrm{N}$ deposition will increase soil $\mathrm{C}$ stocks by increasing forest productivity and subsequent $\mathrm{C}$ input to soil and/or by reducing the decomposition of soil organic matter has been debated. So far, evidence for a $\mathrm{C}$ sink due to $\mathrm{N}$ input is largely based on observations from $\mathrm{N}$ fertilisation experiments, and the measured effects are variable. 
To elucidate the effect of $\mathrm{N}$ deposition on forest soil $\mathrm{C}$ stocks we investigated soils and $\mathrm{C}$ cycling processes in stand-scale $\mathrm{N}$ deposition gradients at the edges of five temperate coniferous forests bordering on agricultural land as well as in an $\mathrm{N}$ addition experiment with two decades of monthly spraying of $\mathrm{N}$ simulating elevated deposition. Nitrogen enrichment (decreased $\mathrm{C} / \mathrm{N}$ ratios in needle litter and forest floor, and sometimes increased soil solution nitrate concentrations) was found at high $\mathrm{N}$ input across the forest edges and in the experiment. Overall, forest floor and mineral soil $(0-5 \mathrm{~cm}) \mathrm{C}$ stocks, assessed along the five edge $\mathrm{N}$ gradients and in the experiment were not significantly related to $\mathrm{N}$ deposition or any of the above-mentioned indicators for $\mathrm{N}$ enrichment. Fine-root biomass and mycorrhiza mycelia production (where investigated) decreased with elevated $\mathrm{N}$, indicating a decreased belowground $\mathrm{C}$ input with increased $\mathrm{N}$ deposition. Decomposition (or respiration) was reduced under elevated $\mathrm{N}$ deposition, indicating a reduced turnover rate of soil organic matter. We conclude that $\mathrm{N}$ deposition at rates common to agriculturally intensive regions in northwestern Europe may reduce the turnover of soil organic matter, but that this positive effect on soil $\mathrm{C}$ stocks may be outweighed by decreases in belowground C inputs, ultimately resulting in no overall change in soil C stocks. Our results contrast with previous studies reporting a significant positive impact of experimental $\mathrm{N}$ addition on $\mathrm{C}$ sequestration in forest soils. Since the investigated forests received $>25 \mathrm{kgN} / \mathrm{ha} / \mathrm{yr}$ in $\mathrm{N}$ deposition we cannot know if low and moderate $\mathrm{N}$ deposition may enhance $\mathrm{C}$ sequestration, but, if so, the effect is likely less than previously reported. In a laboratory incubation of soil from one of the forest edge $\mathrm{N}$ gradients, we observed a reduced temperature sensitivity of soil organic matter turnover at high $\mathrm{N}$ availability (low soil $\mathrm{C} / \mathrm{N}$ ratio). This result demonstrates for the first time that elevated $\mathrm{N}$ deposition moderates the temperature feedback (i.e. the effect of global warming) on decomposition in forest soils.

\subsubsection{Effect of land-use changes}

The forest area in the Nordic and Baltic countries is increasing both through active afforestation and through natural succession on abandoned land. To investigate the effect of this change in land use, we conducted a meta-analysis of soil $\mathrm{C}$ stock change following afforestation in Northern Europe. Effects (response ratios) were calculated for forest floors and mineral soils (0-10 cm and 0-20/30 cm layers) based on paired control (former land use) and afforested plots. We analysed the influence of forest age, former land use, forest type and soil textural 
class. Former land use was a major factor contributing to changes in soil $\mathrm{C}$ after afforestation. In former croplands, soil $\mathrm{C}$ change differed between soil layers and was significantly positive $(20 \%)$ in the $0-10 \mathrm{~cm}$ layer. Afforestation of former grasslands had a small negative (non-significant) effect, indicating limited soil $\mathrm{C}$ change following this land-use change. Forest floors enhanced the positive effects of afforestation, especially in the case of conifers. By separating the periods $<30$ years and $>30$ years since afforestation, we revealed a shift from an initial loss to a later gain of soil C. We conclude that significant soil C sequestration occurs after afforestation of croplands, but not after afforestation of grasslands, and changes are small within a 30-year perspective.

\subsubsection{Nordic soil organic carbon stocks}

A database with roughly 4300 national forest inventory sites from national inventories in the Nordic and Baltic countries has been compiled. The database contains soil $\mathrm{C}$ concentrations and stocks, along with information on other soil parameters, climate, forest properties, etc. Work on harmonising the data from the different countries is in progress, and data will be presented as a soil C map. Furthermore, data will be analysed to identify factors controlling the soil C stocks.

\section{Publications}

Bárcena, T.G., Kiær, L.P., Vesterdal, L., Stéfansdóttir, H.M., Gundersen, P. and Sigurdsson, B.D., 2014. Soil carbon stock change following afforestation in Northern Europe: a meta-analysis. Global Change Biology, doi: 10.1111/gcb.12576.

Gurmesa, G.A., Schmidt, I.K., Gundersen, P. and Vesterdal, L., 2013. Soil carbon accumulation and nitrogen retention traits of four tree species grown in common gardens. Forest Ecology and Management, 309, 47-57.

Hansson, K., Fröberg, M., Helmisaari, H.-S., Kleja, D.B., Olsson, B.A., Olsson, M. and Persson, T., 2013. Carbon and nitrogen pools and fluxes above and below ground in spruce, pine and birch stands in southern Sweden. Forest Ecology and Management, 309: 28-35.

O'Gorman, E., Benstead, J.P., Cross, W.F., Friberg, N., Hood, J.M., Johnson, P.W., Sigurdsson, B.D. and Woodward, G., 2014. Climate change and geothermal ecosystems: natural laboratories, sentinel systems, and future refugia. Global Change Biology, doi: 10.1111/gcb.12602.

Sigurdsson, B.D., Medhurst, J.L., Wallin, G., Eggertsson, O. and Linder, S., 2013. Growth

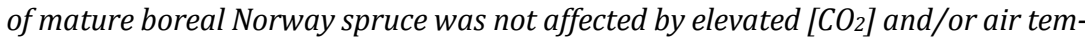
perature unless nutrient availability was improved. Tree Physiology, 33, 1192-1205.

Sigurdsson, B.D. and Gudleifsson, B.E., 2013. Impact of afforestation on earthworm populations in Iceland. Icelandic Agricultural Sciences, 26, 21-36.

Vesterdal, L., Clarke, N., Sigurdsson, B.D. and Gundersen, P., 2013. Do tree species influence soil carbon stocks in temperate and boreal forests? Forest Ecology and Management, 309, 4-18. 


\section{Manuscripts in preparation or submitted:}

Bengtsson et al. (in preparation). Identification of climatic and other drivers of importance for soil C stocks - including Nordic map of SOC.

Clarke et al. (in internal review). Effects of biomass removal on soil carbon. To be submitted to Forest Ecology and Management.

Ginzburg and Gundersen (in review). Elevated $N$ deposition moderates the temperature feedback on decomposition in forest soils. Nature Communications.

Ginzburg et al. (in review). Does nitrogen deposition affect soil carbon stocks? Evaluation of five nitrogen gradients in temperate forests' edges. Global Change Biology.

Ginzburg et al. (in internal review). $N$ fertilization can reduce the decomposition of soil organic matter (SOM) but no sign of higher soil C sequestration. To be submitted to Forest Ecology and Management.

Taylor et al. (in internal review). Ant and earthworm bioturbation in cold temperate ecosystems. To be submitted to Fuctional Ecology

\subsection{Network 3: Climate impacts on fish, fishery industry and management in the Nordic Seas}

Fishing has long been one of the most important industries in the Nordic countries, providing a source of food as well as extensive employment and trade. In recent decades, aquaculture has added substantially to the amount of available fish resources for human consumption as well as trade. Fish, both from the wild and in aquaculture facilities, are affected by ocean climate. The impending warming temperatures caused by anthropogenic (human-induced) GHGs are expected to have major impacts on fish populations and fisheries. While the effects of climate variability have been well studied, the expected historically high temperatures under future climate change present new challenges that call for developing new and interdisciplinary approaches. The geographical distribution of fisheries in the high seas typically spans vast marine areas, often covering several national exclusive economic zones. The assessment and management of these resources are often shared among several countries, therefore requiring a multinational approach.

To meet some of these challenges, a consortium of 13 Nordic institutions joined the Nordic network entitled CLimate Impact on Fish, Fishery Industry and MAnagement in the Nordic Seas (CLIFFIMA-net). The objectives of the network included conducting research on the effects of climate change on the distribution and abundance of marine fish stocks in the Nordic Seas with an emphasis on pelagic stocks in the Norwegian Sea. In addition, it was dedicated to investigating fisheries management issues as well as economic and societal consequences to the fishing industry and local communities in light of the anticipated changes in the 
fish stocks. Important in this research was how potential changes in those fish stocks straddling national boundaries will affect fish treaties and international relations.

The network consists of a core group that carries out the primary work to meet the main objectives of CLIFFIMA and an extended group that participates in meetings, seminars and conferences, thereby contributing towards the network objectives. The central node of the network has been the development of an interactive ecosystem spatial database (i.e. containing data on temperature, salinity, fish abundance and distribution, commercial catch etc.) to help in the analysis of the climatefish relationships. As part of this work, methods and standards for digitisation of old data were initiated and systems for data storing and exchange were developed. The databases and related map generator, Barents Sea Marine Atlas (BarMar) and Nordic Seas Marine Atlas (NorMar), are available for the Barents and Norwegian Seas, respectively, through the CLIFFIMA-net webpage (www.imr.no/cliffima/en). These databases have been used by several Master's students as part of their theses, as well as for analyses and papers in progress by scientists in the network.

For example, the changes in the spatial distribution and abundance of Northeast Arctic haddock (Melongrammus aeglefinus) under climate variability have been explored by utilising the BarMar database in combination with state-of-the-art ocean circulation modelling. During the most recent 30-year period of warming, the haddock stock increased in abundance and moved northeastwards into cooler parts of the Barents Sea. The hypothesis is that the increasing stock size is associated with increased habitat extent coupled with increased ecosystem productivity and not a direct temperature effect on the haddock. The drift of eggs and larvae shows a distinct southern boundary of the spawning fields along the Norwegian shelf break at around $67^{\circ} 30^{\prime} \mathrm{N}$. Other studies that also focused on the role of climate on fish production and distribution included several commercially important species such as Atlantic cod (Gadus morhua), blue whiting (Micromesistius poutassou) and Atlantic mackerel (Scomber scombrus) as well as important forage fish such as polar cod (Boreogadus saida).

In addition to studies on climate variability, several CLIFFIMA investigations developed future climate scenarios and how fish stocks, their community structure and functioning may respond. Sea surface temperatures are expected to increase about $1-3^{\circ} \mathrm{C}$ in the Barents and Norwegian Seas by 2070 , which will reduce sea ice concentrations in the Barents Sea. Melting sea ice and increased precipitation will result in a freshening of the northern North Atlantic in spite of increased salinity of 
the inflowing Atlantic Water to the Nordic Seas. The mixed layer depth (MLD) will decrease because of increased vertical stratification through solar heating and increased freshwater supply. However, the MLD also depends on wind strength, and large uncertainty in future winds makes it difficult to determine exactly how the MLD will change in the future. Phytoplankton production in the Barents Sea is expected to increase in areas where sea ice is reduced owing to increased light levels and a longer production season. In contrast, increased thermal stratification in the Norwegian Sea may reduce primary production by limiting nutrient replenishment.

Calanus finmarchicus, the predominant zooplankton species in the Nordic Seas, is expected to develop more rapidly and reproduce earlier, which could lead to the production of a second generation during the summer, where currently only one is produced. On the other hand, the abundance of the larger Arctic zooplankton species, Calanus glacialis, will likely decrease. It is believed that $C$. finmarchicus will extend its distribution northeastwards in the Nordic Seas while C. glacialis may almost disappear from the Barents Sea with the reduction of Arctic waters. Farther south in the Norwegian Sea, species presently associated with warmer waters are likely to extend their distribution northwards while subarctic species may retreat farther north, as seen in recent warm years. How far north such species will be able to move and still be able to reproduce successfully is uncertain given the reduced light levels at spawning and early larval stages, and the energy they need to gain before overwintering at depth. In the Norwegian and Barents Seas, higher growth rates and improved recruitment survival for fish species such as cod and herring are expected under increasing temperatures based on past observations. Many commercial fish species are expected to expand their distribution northwards and, in the Barents Sea, also eastwards. For Atlantic cod, the combined effects of increased growth rates and recruitment along with distributional shifts will result in increasing biomass and hence catches in both the Russian and the Norwegian sectors of the Barents Sea, but with a higher proportion in the Russian zone compared to today. Polar cod are expected to retreat from the subarctic into the high Arctic. Distributional shifts will result in species invasions, with relatively high numbers of invasions in the Barents Sea compared to other regions of the world's oceans.

An important issue in regards to plankton, fish and marine mammals is the extent to which an open Arctic Ocean will lead to the mixing of Atlantic and Pacific species. This was brought to the forefront with the 
recent re-appearance of Neodenticula seminae, a Pacific diatom, in the Northwest Atlantic after an absence of around 850,000 years.

Initially, the network hoped to base the future scenarios on regional models through downscaling of the larger but lower-resolution IPCC climate models. Unfortunately, these time-consuming downscaling models still did not have the needed accuracy or precision. This is in large part due to the inaccuracies in the global models from which these regional models are derived and the lack of dynamic coupling between the global and regional models. As a result, some CLIFFIMA studies reverted to statistical approaches to generate future climate scenarios. One example used sea temperatures Station-M in the Norwegian Sea from 1948-2010 to suggest the likelihood that temperatures at $150 \mathrm{~m}$ will increase by $0.018-0.044{ }^{\circ} \mathrm{C}$ per year while temperatures at $2000 \mathrm{~m}$ are expected to increase by $0.0024-0.0077^{\circ} \mathrm{C}$ per year.

Not giving up entirely on the regional models, CLIFFIMA, in conjunction with a Norwegian-US project on climate change effects on the ecosystem and fish, has scheduled a joint workshop in May 2014 to explore the most recent IPCC model scenarios as well as regional models. It will (1) examine how the results from such models can be used in ecosystem models to determine the likely changes to the lower trophic levels under anthropogenic climate change, develop ecosystem indicators of such change, and determine related variables indicative of ecosystem productivity in the USA and in the Nordic Seas; (2) use models of living marine resources to explore how to include climate features in future projections and setting of harvest control rules; and (3) determine the potential economic and societal consequences of climate change in the two regions. The workshop will have a limited number of presentations and lots of discussion in order to identify and begin writing papers on these topics.

Regarding aquaculture, scientists at the Institute of Marine Research (IMR) and the Bjerknes Centre for Climate Research (BCCR) contributed through the Research Council of Norway-funded project "Climate Change and the Impact on Farming of Salmon in the Coastal Areas of Norway." The project concluded that an increase in temperature of about $0.5 \%$ increases the average salmon (Salmo salar) productivity by $0.4-3.3 \%$ per year in the short term but less over the long term. However, this effect of productivity will vary spatially, as the industry located in Southern Norway (Vest-Agder, Rogaland and Hordaland counties) may be exposed to excessively high sea temperature in future summer months and may decline as a result.

CLIFFIMA initially laid out an ambitious number of objectives relating to socio-economic and institutional issues. These included: 
- Evaluating how future changes in distribution and abundance of important fish stocks influence current exploitation or quota shares, in order to assess the spatial and substantive coverage of existing international arrangements and institutions, and the reliability of decision-making systems for regulating access and benefit-sharing.

- Assessing a basis for evaluation of the zone attachment of fish resources within and between countries through analyses of surveillance procedures and how they feed into evaluations of geographical distribution of fish and decision-making systems;

- Addressing the need for and effects of revised and more sustainable and flexible harvesting strategies, based on the safeguarding of necessary stocks' resilience in coping with the risk and uncertainty from expected climate changes.

- Generating scenarios on the potential effects of climate changes on industries and local communities, including evaluation of economic and other societal consequences of changes in geographical distribution of the fish stocks and how the management and policy systems are able to adapt to these.

- Assessing the energy consumption of the fishing fleet due to changing spatial distribution of fish resources and determining the effectiveness and potential of different mitigation measures to reduce GHG emissions by the fishing fleet.

These are extremely complex issues, and it has not been possible to address them all in the context of CLIFFIMA. Activities to date have focused upon spatial distribution issues relating to climate and economics, while the May workshop will examine the potential economic and societal consequences of climate change in the marine environment.

In broad terms, CLIFFIMA has concentrated on a subset of the institutional issues and socio-economic questions. There is, however, a rapidly evolving literature in the field and most of the themes that are raised in the above objectives of CLIFFIMA are now being addressed in the literature. Also, there is a substantial number of scientific as well as policyoriented meetings that have recently been held or will be in coming months on these issues, discussing how they can be approached and addressed, e.g. ICES Northwest Arctic Fisheries Working Group, theme sessions and workshops at annual ICES and PICES meetings, and workshops by the Ecosystem Studies of Subarctic Seas (ESSAS) programme. Several 
CLIFFIMA members will be participating in these broader-based meetings, bringing with them results from CLIFFIMA work and discussions.

In terms of fisheries management, the effect of climate on exploitation and quota shares, reliability of decision-making systems, zone attachment and harvest control rules, energy consumption of the fish sector, and economic and societal consequences of future changes in the stocks have been considered through papers, as part of the two conferences (Nordic Climate-fish 1 and 2) and at a special conference on these themes (see CLIFFIMA homepage for further details).

During the CLIFFIMA-net project there has been affiliation with the Joint Nordic Master's Programme on Marine Ecosystems and Climate that has resulted in production of several theses supervised by CLIFFIMA members. In addition to this master's course, which exposes students to the science and scientists from several Nordic countries, CLIFFIMA has supplied several established scientists with mobility grants to increase the interaction and cooperation between Nordic oceanographic institutions. Three larger conferences have been held, as well as several smaller meetings and seminars. More details can be found at the CLIFFIMA homepage.

\section{Publications}

Ankjærø, T., Christensen, J.T. and Grønkjær, P., 2012. Tissue-specific turnover rates and trophic enrichment of stable $N$ and $C$ isotopes in juvenile Atlantic cod Gadus morhua fed three different diets. Marine Ecology Progress, Series 461, 197-209.

Drinkwater, K.F., Colbourne, E., Loeng, H., Kristiansen, T. and Sundby, S., 2013. Comparison of the atmospheric forcing and oceanographic responses between the Labrador Sea and Newfoundland Shelves and the Norwegian and Barents Seas. Progress in Oceanography, 114, 11-25.

Drinkwater, K.F., Miles, M., Medhaug, I., Otterå, O.H., Kristiansen, T., Sundby, S. and Gao, Y., 2014 (in press). The Atlantic Multidecadal Oscillation: its manifestations and impacts with special emphasis on the Atlantic region north of $60^{\circ} \mathrm{N}$. Journal of Marine Systems.

Ekerhovd, N.-A., 2013. Climate change and the benefits of cooperation in harvesting North-East Arctic cod. Strategic Behavior and the Environment, 3, 7-30.

Ekerhovd, N.-A. and Kvamsdal, S.F., 2013. Modeling the Norwegian Sea "pelagic complex". An application of the Ensemble Kalman Filter. SNF Working Paper A07/13. Centre for Applied Research (SNF), Norwegian School of Economics (NHH).

Eliasen, K., Reinert, J., Gaard, E., Hansen, B., Jacobsen, J.A., Grønkjær, P. and Christensen, J.T., 2011. Sandeel as a link between primary production and higher trophic levels on the Faroe shelf. Marine Ecology Progress, Series 438, 185-194.

Ferreira, A.S., Stenevik, E.K., Vollset, K.W., Korneliussen, R. and Folkvord, A., 2012. Vertical migration of Norwegian spring-spawning herring larvae in relation to predator and prey distribution. Marine Biology Research, 8, 605-614.

Friedland, K.D., Stock, C., Drinkwater, K.F., Link, J., Leaf, R., Shank, B., Rose, J., Pilskaln, C.H. and Fogarty, M., 2012. Pathways between primary production and fisheries yields of Large Marine Ecosystems. PlosOne 7: e28945. doi:1371/journal.pone.0028945. 
Grønkjær, P., Petersen, J.B., Ankjærø, T.T., Kjeldsen, H., Heinemeier, J., Steingrund, P., Nielsen, J.M. and Christensen, J.T., 2013. Stable $N$ and $C$ isotopes in the organic matrix of fish otoliths: Validation of a new approach for studying spatial and temporal changes in the trophic structure of aquatic ecosystems. Canadian Journal of Fisheries and Aquatic Sciences, 70, 143-146.

Hansen, J.H., Hedeholm, R.B., Sünksen, K., Christensen, J.T. and Grønkjær, P., 2012. Spatial variability of carbon $(\delta 13 C)$ and nitrogen $(\delta 15 N)$ stable isotope ratios in an Arctic marine food web. Marine Ecology Progress, Series 467, 47-59.

Hedeholm, R, Grønkjær, P. and Rysgaard, S., 2011. Energy content and fecundity of capelin (Mallotus villosus) along a 1,500-km latitudinal gradient. Marine Biology, 158, 1219-1330.

Hedeholm, R., Grønkjær, P. and Rysgaard, S., 2012. Feeding ecology of capelin (Mallotus villous Müller) in West Greenlandic waters. Polar Biology, 35, 1533-1543.

Hollowed, A.B., Barange, M., Beamish, R., Brander, K., Cochrane, K., Drinkwater, K., Foreman, M., Ito, S.-I., Hare, J., Holt, J., Kim, S., King, J., Loeng, H., MacKenzie, B., Mueter, F., Okey, T., Peck, M.A., Radchenko, V., Rice, J., Schirripa, M., Yatsu, A. and Yamanaka, Y., 2013. Projected impacts of climate change on marine fish and fisheries. ICES Journal of Marine Science, 70, 1023-1037.

Hunt, G.L., Jr., Blanchard, A.L., Boveng, P., Dalpadado, P., Drinkwater, K., Eisner, L., Hopcroft, R., Kovacs, K.M., Norcross, B.L., Renaud, P., Reigstad, M., Renner, M., Sjkoldal, H.R., Whitehouse, G.A. and Woodgate, R., 2013. The Barents and Chukchi Seas: Comparison of two Arctic shelf ecosystems. Journal of Marine Systems, 109110, 43-68.

Kristiansen, T., Stock, C., Drinkwater, K.F. and Curchitser, E.N., 2014. Mechanistic insights into the effects of climate change on larval cod. Global Climate Change. doi:10.1111/gcb.12489.

Link, J.S., Gaichas, S., Miller, T.J., Essington, T., Bundy, A., Boldt, J., Drinkwater, K.F. and Moksness, E., 2012. Synthesizing lessons learned from comparing fisheries production in 13 northern hemisphere ecosystems: emergent fundamental features. Marine Ecology Progress, Series 459, 293-302.

Lorentzen, T., 2014. Statistical analysis of temperature data sampled at Station-M in the Norwegian Sea. ICES Journal of Marine Science, 130, 31-46.

Neuheimer, A.B. and Grønkjær, P., 2012. Climate effects on size-at-age: growth in warming waters compensates for earlier maturity in an exploited marine fish. Global Change Biology, 18, 1812-1822.

Ottersen, G., Stige, L.C., Durant, J.M., Chan, K.-S., Rouyer, T., Drinkwater, K. and Stenseth, N.C., 2013. Temporal shifts in the recruitment dynamics of North Atlantic fish stocks: Effects of spawning stock and temperature. Marine Ecology Progress, Series 480, 205-225.

Petitgas, P., Rijnsdorp, A.D., Dickey-Collas, M., Engelhard, G.H., Peck, M.A., Pinnegar, J.K., Drinkwater, K.F., Huret, M. and Nash, R.D.M., 2013. Impacts of climate change on the complex life cycles of fish populations. Fisheries Oceanography. doi:10.1111/fog.12010.

Salihoglu, B., Neuer, S., Painting, S., Murtugudde, R., Hofmann, E., Steele, J., Hood, R., Legendre, L., Lomas, M., Wiggert, J., Ito, S., Lachkar, Z., Hunt, G., Drinkwater, K. and Sabine, C., 2013. Bridging marine ecosystem and biogeochemistry research: Lessons and recommendations from comparative studies. Journal of Marine Systems, 109110, 161-175. 


\section{Manuscripts submitted or in preparation}

Eliasen, K., Olsen, B., Reinert, J., Steingrund, P., Grønkjær, P., Christensen, J.T., Hansen, B., Gaard, E. and Jacobsen, J.A. Sandeel, Dependent seabird breeding at the Faroes. Submitted to Seabirds.

Landa, C., Ottersen, G., Sundby, S., Dingsør, G. and Stiansen, J.E. Recruitment, distribution boundary and habitat temperature of an arcto-boreal gadoid in a climatically changing environment - a case study on Northeast Arctic haddock (Melanogrammus aeglefinus). Submitted to Fisheries Oceanography.

Eliasen, K., Grønkjær, P., Christensen, J.T., Hansen, B., Jacobsen, J.A., Steingrund, P. and Debes, H. Indications of climate induced reductions in the energetic value of Faroese sandeel. In preparation.

Christensen, J.T., Eliasen, K., Grønkjær, P., Olsen, B., Hammer, S., Gaard, E., Steingrund, P. and Hansen, B. Sandeel trophic relationships on the Faroe Shelf revealed by stableisotope analysis. In preparation.

\section{Ph.D. thesis}

Xiaozi, L., 2012. Essays on economic optimization: bridging fisheries economics and fisheries biology. Ph.D. Norwegian School of Economics.

\section{Master's theses}

Castaño-Primo, R., 2012. A model approach to the spawning grounds and early life history of Northeast Arctic haddock (Melongrammus aeglefinus). Master's. Geophysical Institute, University of Bergen.

Hansen, K.S., 2012. Small scale distribution of fish in offshore wind farms. Master's. University of Copenhagen and DTU Aqua.

Landa, C.S., 2012. Geographical distribution and abundance of Northeast Arctic haddock (Melongrammus aeglefinus) in a fluctuating climate. Master's. Geophysical Institute, University of Bergen.

Jähkel, A., 2013. Tuning the diet of Northeast Arctic cod in the Barents Sea - An exploration with the end-to-end model Atlantis. Master's. Geophysical Institute, University of Bergen.

Rajasakaren, B., 2013. Distribution of polar cod (Boreogadus saida) in the Barents Sea - A useful indicator of climate change? Master's. Geophysical Institute, University of Bergen.

\subsection{Network 4: Nordic research network on animal genetic resources in the adaptation to climate change - AnGR-NordicNET}

This research network aimed to contribute to developing a Nordic knowledge-base for policy-making for the conservation, utilisation and investigation of animal genetic resources in the face of climate change. Five work-packages (WP) were defined to meet this goal. The results of each of these are outlined below. 


\subsubsection{WP1}

The objective of WP1 was to review current knowledge of climate change effects on the Nordic agroecosystems and livestock production by conducting a literature survey. The initial plan of publishing one review was expanded to include two manuscripts: one paper on future trends in livestock production in the face of climate change and a growing human population, and a second article focusing on the role of farm animal genetic resources in mitigation.

The first literature survey, "Current status of livestock production in the Nordic countries and future challenges with a changing climate and human population growth," has been submitted to Acta Agriculturae Scandinavica (Åby et al. 2014). It aims at: 1) giving an overview of current Nordic livestock production, reviewing important trends, and discussing relevant factors for future production conditions for Nordic livestock production; 2) describing the use of land, energy, mineral fertiliser, pesticides and feed resources for livestock production, in addition to the GHG emissions originating in agriculture and livestock; and 3) reviewing important factors for the future conditions of Nordic livestock production, such as human population growth and climate changes. The paper also discusses possible adaptations of Nordic livestock production to these new production conditions, thereby ensuring food security while reducing GHG emissions.

The general conclusions of the survey were that Nordic livestock production needs to focus on the implementation of climate-smart agriculture. This includes increasing the degree of self-sufficiency by relying more on domestic, rather than imported, feed resources. Animal productivity needs to be increased and the environmental impact, mainly GHG emissions from livestock, needs to be reduced. Overall, there is a great need for more knowledge on how to optimise Nordic livestock production in response to the changes brought about by climate change.

The second paper will be submitted to Frontiers in Livestock Genomics Advances in Farm Animal Genomic Resources and focuses mainly on reduction of the impact of livestock production on the climate. There are several practical approaches that could advance livestock production systems' potential to adapt to climate change and reduce GHG emissions, including altering pasture rotations, modifying grazing times and reproduction timing, altering forage crops, ensuring an adequate water supply, using supplementary feeds and concentrates, and benefiting from the reduced need for winter housing in cold climates. In addition, there are various political measures that can be employed to regulate livestock production and consumption of products of animal origin and that can lead to a reduction of 
GHG emissions. Political regulation through taxes and subsidies can diminish GHG emissions by promoting new technologies, research results and innovation that will influence the use of various agricultural inputs and applied practices in livestock production, the portfolio of products cultivated and produced for the market, and consumer behaviour.

Moreover, management of available farm animal genetic resources should be considered in adaptation and climate change mitigation strategies. This includes choosing between breeds, and even between farm animal species, to find those that are suitable for changing circumstances and applying "mitigation and adaptation breeding" to select breeds and animals with useful phenotypes and genotypes.

The key issue in mitigating harmful GHG effects induced by livestock production on global warming is reducing $\mathrm{CH}_{4}$ (methane) emissions from ruminants, especially from beef and dairy cattle. There are difficulties associated with including methane production as one of the traits controlled in ruminant production, collecting data for breeding schemes on farms and including the trait $\left(\mathrm{CH}_{4}\right.$ emission) in the total breeding value in practice. Techniques for this must be developed. In the meantime, we can improve the trait indirectly through selection of traits that have a correlated effect on emissions and improve the efficiency of the livestock production system (fertility, residual feed intake, longevity). In addition, there may be increasing demand for robust animal breeds that have the potential to adapt to altered environmental conditions and tolerate new livestock diseases and pests. Characterisation of breeds with modern genomic tools, such as whole-genome sequencing and transcriptome profiling, can be applied to identify breeds that have the potential to tolerate new pathogens and are genetically adapted to marginal circumstances. This will provide critical information for conservation programmes for farm animal genetic resources.

\subsubsection{WP2}

Dairy cattle breeding in the Nordic countries is currently not specialised with regard to production systems or geographical region, and therefore not with regard to climatic parameters either. It is unclear whether this chosen compromise satisfies needs at the extremes of environmental gradients and herd management. To assess this, an understanding of genotype by environment ( $\mathrm{G} \times \mathrm{E}$ ) effects and their impact on production traits, as well as on functional traits such as fertility and longevity, is needed. The aim of WP2 was thus to assess G x E effects on fertility, longevity and milk production in dairy cattle. 
The most important climate changes that may affect dairy production are increases in temperature and humidity during summer. As suggested by the results of a number of US studies, the trait that is most likely to be affected is fertility. A literature survey was conducted in WP2 and is included in a Ph.D. project, as well as in a book chapter (Misztal and Løvendahl 2012).

Traditional fertility data was obtained from a large number of Danish dairy cows in commercial farms with state-of-the-art recording equipment and automated milking. Recorded data also included activity data from neck-mounted activity tags that read physical activity at two-hour intervals, thus providing good resolution. The equipment is used to detect cows in oestrus and thus indirectly to monitor fertility. Activity data may also be used for objectively assigning strength and duration of oestrus episodes. Thus far, data has been obtained from 80 herds with a total of nearly 17,000 cows and delivered by the Danish Knowledge Centre for Dairy and Cattle Farming in Skejby. Pedigree data is also available, so estimates of heritabilities and genetic correlations can be obtained as well.

Estimates of heritability for traditional fertility traits were rather low, which is consistent with expectations from previously reported findings. The definition of activity-based fertility traits involved development and validation of detection algorithms. Previously published algorithms had to be modified in order to be able to handle commercial herd data, which is often affected by many minor errors. By applying modified and optimised algorithms it was found that a) the activity-based traits have higher heritability than traditional traits, b) they are genetically highly correlated so that they are very similar, and c) the activity-based traits also provide information about strength and duration of oestrus that show genetic variation. This has been reported at meetings, and will be presented at the upcoming WCGALP in Vancouver (Ismael et al. 2014).

\subsubsection{WP3}

There is an urgent need to conserve genetic diversity in farm animal populations in order to maintain adaptation and breeding potential. Characterising and prioritising populations for conservation comprise one challenge. The aim of WP3 was to assess the accuracy of alternative types of genetic markers and genetic measures estimated from these markers in quantifying genetic diversity.

A computer simulation model of the evolution of populations, which simulates whole-genome sequence data, was developed and programmed. The whole-genome sequence genotypes and the trait values of 
the animals were outputted for further analysis using various measures of genetic diversity.

Prioritising breeds for conservation is of high importance for halting the erosion of genetic diversity observed in livestock species, as extinction of local breeds continues and the resources available for conservation programmes are limited. Current approaches usually only take neutral genetic diversity into account, but adaptation of breeds to different environments also contributes to the diversity found in livestock species. Here we developed two measures of adaptive variation. The adaptive diversity in a trait is the excess of variance found in genotypic values relative to the variance that would have been expected in the absence of selection. The adaptivity coverage of a set of breeds quantifies how well the breeds could be adapted to a wide range of environments within a limited timespan. Additionally, genome-based measures of neutral diversities were obtained that correspond to well-known pedigree-based definitions. Objective functions taking both adaptive diversity and neutral diversity into account were proposed and compared using simulated data. The values of breeds for conservation of adaptive diversity were only slightly correlated with their values for conservation of neutral diversity, but their values for conservation of adaptivity coverage showed a reasonable correlation with both adaptive and neutral diversity when the appropriate timespan was chosen.

To better understand the population structure of cattle and to detect genomic regions showing signatures of diversifying selection and adaptation, we investigated 10 Eurasian Bos taurus cattle breeds (taurine cattle breeds) with a whole-genome SNP array (about 50000 SNP markers). Population structure analysis indicated four distinct groups, the most divergent extreme being the Yakutian cattle from Russia. We also found that present effective population sizes for the breeds are alarmingly low, indicating the need for conservation activities. When comparing regions showing signatures of selection to known QTL regions, intensively selected dairy breeds showed selection in the regions associated with milk production, as expected. Interestingly, in the local native breeds, strong signals were detected in regions associated with feed efficiency. This could indicate footprints of adaptation to local conditions and to feed with low nutritional content in particular. The link obtained from the genome scan between genotype, phenotype and fitness of the population can offer valuable information in the future. Meanwhile, local genetic resources may provide unique genetic material for future breeding purposes, such as introgression and genomic selection approaches. 


\subsubsection{WP4}

The availability of farm animal genetic diversity to meet future breeding goals, which will change at a pace with climate change, is merely a prerequisite for the adaptation process. It is paramount that favourable traits are either swiftly introduced into the currently utilised breeds or that the current breeds are replaced by new and better adapted breeds, as climate change will call for new adaptations. The aim of WP4 was to compare alternative methods for introducing favourable traits into farm animal populations.

Climate change leads to new conditions for livestock production, and genetic adaptations are needed to avoid reduced animal productivity. It is insufficient to have genes affecting adaptive traits among a conserved set of breeds. Such genes need to be implemented quickly within the currently used breeds or the breeds need to be replaced with better adapted, possibly crossbred, populations. Computer simulations were performed comparing different selection strategies applied to two subpopulations divergently selected for a production or fitness trait. The selection strategies were: 1) selection within the production population using BLUP; 2) selection within the production population using genomic selection; 3) crossbreeding between the production population and the fitness population using BLUP; 4) crossbreeding using genomic selection (GBLUP ${ }_{C B}$ ). The results clearly showed that the alternative selection strategies resulted in different adaptation rates. A combination of crossbreeding and genomic selection resulted in the fastest genetic adaptation. The adaptation potential was also dependent on the initial difference in genetic level between the cross- and purebred populations. GBLUP $_{\mathrm{CB}}$ resulted in the highest genetic gains for the production population: $\sim 5$ times higher than traditional BLUP purebreeding. For the fitness population, this figure was $\sim 2$ times higher than traditional purebreeding. However, further studies including other selection strategies and practical livestock breeding schemes need to be carried out.

\subsubsection{WP5}

WP 5 aimed to summarise the new scientific knowledge gained from the activities of the other WPs and to derive recommendations for strategies addressing the conservation and utilisation of animal genetic resources.

Two network members participated in the workshop organised by the Nordic Council of Ministers in October 2013 to discuss the final report on climate change that will form the basis for recommendations to the Nordic Council and the governments of the Nordic countries. The 
main points from the network's projects and the workshops are presented in the final report.

The members of the AnGR-NordicNET met for a two-day workshop in November 2013 to draft the contributions of the network to the report. The contributed chapters include discussions of the effects of climate change on livestock production, possible adaptation and mitigation of GHG emissions, as well as possible use of genetic resources to meet foreseen challenges.

\section{Publications}

Hietala, P., Wolfová, M., Wolf, J., Kantanen, J. and Juga, J., 2014a. Economic weights for breeding goal traits and residual feed intake for Finnish Ayrshire cattle. Poster presentation. Book of Abstracts, Genetic Resources for Food and Agriculture in a Changing Climate. Lillehammer, Norway, 27-29 January 2014, p.61.

Hietala, P., Wolfová, M., Wolf, J., Kantanen, J. and Juga, J., 2014b. Economic values of production and functional traits, including residual feed intake, in Finnish milk production. Journal of Dairy Science, 97(2), 1092-1106.

Hietala, P., Bouquet, P. and Juga, J., 2014. The potential to mitigate greenhouse gas emissions in Finland by intensifying beef production from dairy herds. Abstract submitted to the conference Livestock, Climate Change and Food Security. Madrid, Spain, 19-20 May 2014.

Ismael, A., Løvendahl, P. and Strandberg, E., 2012. Environmental sensitivity in dairy cattle with focus on fertility traits. Proceedings of the AnGR-NordicNET Workshop, Genotype-by-Environment Interactions and Adaptation of Farm Animals on Phenotypic and Molecular Levels. Tuusula, Finland 7-8 November 2012. Nordic Genetic Resource Center, Ås, Norway, pp.13-14.

Iso-Touru, T., Vilkki, J. and Kantanen, J., 2012. Whole-genome scanning in cattle breeds to detect selection signatures. Proceedings of the AnGR-NordicNET Workshop, Genotype-by-Environment Interactions and Adaptation of Farm Animals on Phenotypic and Molecular Levels. Tuusula, Finland, 7-8 November 2012, p.17.

Iso-Touru T., Tapio, M., Vilkki, J,. Kiseleva, T., Ozerov, M., Popov, R. and Kantanen, J., 2014. Identification of the genetic structure and divergently selected genomic regions of Eurasian cattle populations using a whole-genome SNP array. Submitted.

Meuwissen, T., 2012. Strategy building in AnGR-NordicNET, look into the future. Proceedings of the AnGR-NordicNET Workshop, Genotype-by-Environment Interactions and Adaptation of Farm Animals on Phenotypic and Molecular Levels. Tuusula, Finland, 7-8 November 2012, p.21.

Kantanen, J., Løvendahl, P., Strandberg, E., Eythorsdottir, E., Li, M.-H., KettunenPræbel, A. and Meuwissen, T.H.E., 2014. Changes in agroecological circumstances and the role of farm animal genetic resources in mitigation and adaptation issues in the Nordic livestock production. To be submitted to Frontiers in Livestock Genomics - Advances in Farm Animal Genomic Resources.

Kantanen, J., Løvendahl, P., Strandberg, E., Eythorsdottir, E., Li, M.-H., Kettunen-Præbel, A., Berg, P. and Meuwissen, T.H.E., 2014. Changes in agroecology and the role of farm animal genetic resources in mitigation and adaptation issues in the Nordic livestock production. Poster presentation. Book of Abstracts, Genetic Resources for Food and Agriculture in a Changing Climate. Lillehammer, Norway, 27-29 January 2014, p.63. 
Meuwissen, T., 2014. Strategy building in farm animal practices, look into the future. Book of Abstracts, Genetic Resources for Food and Agriculture in a Changing Climate. Lillehammer, Norway, 27-29 January 2014.

Misztal, I. and Løvendahl. P., 2012. Genotype by Environment Interactions in Commercial Populations. In: R.J. Collier and J.L. Collier, eds. 2012. Environmental Physiology of Livestock, 1st edition. Wiley-Blackwell, pp.289-307.

Sayed, A.I., Strandberg, E. and Løvendahl, P., 2014. Automated estrus traits: higher heritability and better suited to study GxE. Poster presentation. Book of Abstracts, Genetic Resources for Food and Agriculture in a Changing Climate. Lillehammer, Norway, 27-29 January 2014, p.70.

Sayed, A.I., Sørensen, M.K., Fogh, A., Strandberg, E. and Løvendahl, P. Estrus traits derived from activity measurements are heritable and closely related to conventional estrus traits. In preparation, to be submitted to Journal of Dairy Science.

Sayed, A.I., Kargo, M., Fogh, A., Strandberg, E. and Løvendahl, P., 2014. Estrus traits derived from activity measurements are heritable and closely related to conventional estrus traits. Proceedings from the 10th World Congress of Genetics Applied to Livestock Production.

Wellmann, R., Bennewitz, J. and Meuwissen, T., 2014. A unified approach to characterize and conserve adaptive and neutral genetic diversity in subdivided populations. Submitted to Genetics.

Åby, B.A., Kantanen, J. and Meuwissen, T., 2014. Current status of livestock production in the Nordic countries and future challenges with a changing climate and human population growth. Submitted to Acta Agriculturae Scandinavica, Section A - Animal Science.

Åby, B.A. and Meuwissen, T., 2014. Selection strategies utilizing genetic resources to adapt livestock to climate change. Submitted to the 10th World Congress of Genetics Applied to Livestock Production. Vancouver, Canada, 17-22 August 2014.

Åby, B.A. and Meuwissen, T., 2014. Selection strategies utilizing genetic resources to adapt livestock to climate change. Submitted to Journal of Animal Science.

\subsection{Network 5: Nordic Forage Crops Genetic Resource Adaptation Network NOFOCGRAN}

The aim of this research network has been to develop a strong network of researchers and students involved in the development of knowledge, methods and germplasm as the basis for future development of cultivars of perennial forage grasses and legumes for the Nordic region. Forage grass species and cultivars show great variability in their responses to environmental conditions such as temperature and light conditions. Thus, there is genetic potential to adapt forage grass production to future climates. In principle, perennial forage grass species can benefit from extended growth periods caused by climate change both in early spring and late autumn. The key issue is to explore forage grass genetic resources and identify traits that are important for high yields in the future under changed overwintering conditions as well as management practices.

The following activities have been carried out by the network: 


\subsubsection{Workshops and international conference}

Two workshops/meetings have been held, the first at the University of Helsinki, Finland, on 18-20 May 2011. Twenty-eight members of the network participated, together with Dr Ben Trevaskis of the Commonwealth Scientific and Industrial Research Organisation (CSIRO), Australia, an internationally renowned expert on the genetics of vernalisation in grasses who was invited as an international guest scientist. The workshop consisted of presentations from ongoing research activities in the partner groups, given mostly by young scientists and Ph.D. students. The workshop/meeting was very successful and useful in terms of fostering more interaction between the network groups.

The second meeting was organised by the University of Aarhus, Flakkebjerg, Slagelse, Denmark, as a Ph.D. course on bioinformatic analyses of RNA sequencing data followed by a two-day seminar from 7-11 May 2012. An excursion to the main field station of the plant breeding company DLF Trifolium at Store Heddinge was also conducted during the workshop. The short-term Ph.D. course had nine participants (restricted number), and 33 members of the network participated in the workshop.

The project leader and a network representative from the Nordic Genetic Resource Center (NordGen) took part in a workshop in Copenhagen, Denmark, on 10-11 December 2012 to discuss the policy briefs.

The final international conference, entitled "Genetic Resources for Food and Agriculture in a Changing Climate," was held in Lillehammer, Norway, on 27-29 January 2014. It was organised by the following networks: Nordic Forage Crops Genetic Resource Adaptation Network (NOFOCGRAN), Sustainable Primary Production in a Changing Climate, Nordic Research Network on Animal Genetic Resources in the Adaptation to Climate Change (AnGR-NordicNET), and Arctic char: A species under threat and with great potentials in the age of climate change (NORDCHAR). The Nordic Genetic Resource Center - via NordGen Farm Animals and NordGen Forest, Norway - also took active part in the scientific and local organisation of the conference. The main aims of the conference were to contribute to understanding climate change and its predicted impact on agriculture and forestry by: i) increasing our understanding of adaptive genetic diversity and adaptation, ii) assessing how genetic resources for food and agriculture are affected by the changing climate, iii) discussing the consequences that climate change challenges will have for the sustainable utilisation of plant, animal and forest genetic resources, and iv) presenting the scientific knowledge accumulated by four networks under the research programme Climate Change Impacts, Adaptation and Mitigation in Nordic Primary Industries, established by the Nordic Council 
of Ministers in collaboration with NordForsk. The conference sought to bring together participants from all areas relevant to genetic resources for food and agriculture in a changing climate. The conference was attended by some 130 participants and was considered very successful. Abstracts and presentations are available at http://climate.nordgen.org/.

\subsubsection{Modelling}

A modelling study to predict and target desired cultivar traits for yield and winter survival of perennial grasses under predicted future climates in the Nordic countries has been conducted. This work was integrated with modelling activities under the research project "VARCLIM - Understanding the genetic and physiological basis for adaption of Norwegian perennial forage crops to future climates," funded by the Research Council of Norway, and activities under the "Network of Nordic forage modelling. Climate change assessments based on Nordic data" - a network funded by the Nordic Joint Committee for Agricultural and Food Research (NKJ). The simulations indicate that frost injury on timothy (Phleum pratense) during winter will increase at continental locations in the Nordic countries due to reduced snow cover, while perennial ryegrass (Lolium perenne) will be injured at coastal locations as well. Injuries due to ice encasement will probably increase, mainly at continental sites. Frost injuries during spring will increase most at coastal locations. Independent of which climate change model is chosen, the simulations show that the dry matter yields will increase due to extended growth seasons with higher average temperatures. Physiological studies conducted by the network are providing parameter values for simulations, and these indicate that it will be more efficient to increase the maximum frost tolerance of perennial ryegrass than to improve the ability to reacclimate in order to prevent injuries from warm spells during unstable winters. These results are important for selecting strategies for breeding perennial ryegrass cultivars with improved winter survival.

\subsubsection{Multi-site field trials for estimating phenotypic stability of winter survival and yield}

Field trials were sown at locations in four countries: Keldnaholt, Iceland (64.132442, 21.856903), Fureneset, Norway (61.359315, 5.716434), Jokioinen, Finland $(60.803842,23.485758)$ and Store Heddinge, Denmark $(55.311108,12.357655)$ in spring 2011 and an identical field trial was sown in Länghem, Sweden $(57.601506,13.244271)$ in spring 2012. 
Twenty genetically diverse Nordic and European Lolium perenne and Festulolium cultivars, with meadow fescue (Festuca pratensis) cultivars as controls, are being tested in the field trials. Lolium perenne and Festulolium (hybrids between Lolium spp. and Festuca spp.) are promising "new" species for the northern parts of Scandinavia when the climate is warming. Lolium perenne is the dominating forage grass species in Denmark and further south in Western Europe, regions with relatively mild coastal winter climates, and it gives high yields with very good nutritive quality. One major aim has been to investigate whether there is variation in growth cessation in the autumn among the cultivars. The timing of growth cessation is very important in relation to the longer growth season resulting from climate change and because of the tradeoff with winter survival. Therefore, at three locations (Iceland, Norway and Finland), plants were collected from the field at various time points during winter 2012/2013 and winter 2013/2014, and subjected to artificial freezing tests to determine their freezing tolerance ( $\mathrm{LT}_{50}$-lethal temperature with $50 \%$ of the population surviving). The field experiments are located at distant locations spanning a wide range of coastal and continental climates. Preliminary observations show that the cultivars are displaying very different adaptations. The three winters have also been very different: the first (2011/2012) imposed little winter stress, the next (2012/2013) was very stressful, and the third $(2013 / 2014)$ winter was unusually mild but with high precipitation. The different winter climates sampled in these experiments provide an excellent opportunity to study the winter survival and stability of the cultivars. In order to obtain at least two full growing seasons at all locations (the experiment in Sweden was established one year later than the others), and to test for freezing tolerance during winter 2013/2014, the timeframe of the NOFOCGRAN network was extended, and the network will report the results from these experiments after August 2014.

In the Norwegian VARCLIM project, surviving plants from multi-site field experiments with pre-breeding materials (mixture of adapted and exotic germplasms) of several species have been sampled for creation of new breeding populations. Field trials were established at five locations in Norway, covering coastal-continental and south-north gradients, and were cut for three years. DNA from leaf samples was obtained from all location $\mathrm{x}$ year combinations and is being genotyped by sequencing at Aarhus University, Flakkebjerg, Slagelse, Denmark. The same is being done with the Lolium perenne and Festulolium cultivars included in the multi-site Nordic experiments mentioned above. 


\subsubsection{Physiological studies of cold acclimation, vernalisation and flowering responses in relation to winter survival}

The predicted future unstable winter climate with multiple thawing/freezing incidents and more direct frost exposure will pose new types of winter stress, so cultivars with rapid cold acclimation and reacclimation responses will be needed. Cold acclimation/reacclimation in perennial grasses is intimately linked to the transition of tillers from the vegetative to the reproductive stage. Thus, functional studies of interacting gene networks involved in cold acclimation/freezing tolerance and vernalisation/photoperiodic floral induction are needed. A large-scale RNA sequencing experiment with genotypes of Lolium perenne and Festulolium differing in vernalisation requirement has been conducted as part of the VARCLIM project. Plants were subjected to combinations of vernalisation, cold acclimation, deacclimation and reacclimation, and at defined time points plants were freeze-tested and tissues were sampled for transcriptome analyses (RNAseq). The idea was to study the global gene expression during the cycle of vernalisation, cold acclimation, deacclimation and reacclimation in relation to the level of freezing tolerance expressed, and to investigate whether this is dependent on vernalisation sensitivity. The freezing tests found significant differences among genotypes in maximum freezing tolerance and rates of deacclimation and reacclimation, indicating that it may be possible to manipulate these traits by breeding, perhaps by using molecular markers instead of laborious multi-location-year field experiments. The large RNAseq datasets are being analysed and manuscripts are being prepared (see list of publications). Candidate gene expression during cold acclimation/deacclimation/reacclimation and critical daylengths for growth cessation have been studied in the same Lolium perenne and Festulolium clones as those being used in the RNAseq study. This is a joint investigation between network partners in Norway and Finland. The data will be analysed and published during autumn 2014 .

Studies of growth cessation and photosynthetic acclimation in Lolium perenne and Festulolium show that a clear relationship exists between leaf elongation rate and photosynthetic acclimation. Selection for increased freezing tolerance in a Festulolium population (two generations) indicates that this induces earlier growth cessation. Studies in controlled environments show reduced freezing tolerance and lower photosynthetic acclimation of timothy, perennial ryegrass and red clover if the temperature is higher than normal during preacclimation in the autumn, especially at the shortest daylength. These are the climatic conditions 
expected to occur more often in connection with the predicted climate changes, especially in the northern regions of Scandinavia.

\subsubsection{Disease resistance in a future climate}

In the VARCLIM project, project partners are also studying resistance against snow mould (Microdochium nivale), a major cause of winter damage of perennial ryegrass and Festulolium in northern environments. This research involves screening a number of cultivars and breeding populations for resistance against a range of Microdochium strains, field trials using artificial inoculations, development of methods (PCR) for diagnosing and quantifying the fungus, and a large-scale RNA sequencing study aiming to elucidate genes involved in the initial response to fungal infection. These data are the basis for an M.Sc. degree (Anil Kunapareddy) completed in December 2013, and a Ph.D. thesis (Mohamed Abdelhalim) to be completed in autumn 2014.

\subsubsection{Scientific gaps identified in the network}

Genomic - Better genomic resources (SNP markers, whole genome sequences) of forage crop species are needed in order to perform whole genome scans and link phenotypic and molecular variation. Forage crop species are lagging behind the development of other crops, e.g. cereals, due to much less investment in R\&D. The only species with genomic resources at a level that makes it feasible to apply the most advanced methods for understanding the genome is perennial ryegrass (Lolium perenne). This species is therefore the focus of many projects, in addition to being a promising species in the wake of climate change.

Physiology - Understanding and the ability to manipulate growth cessation in the autumn and the variation in resistance towards deacclimation and reacclimation during warm spells are needed. The growth season will be longer, and new cultivars that can utilise the longer season while at the same time withstanding the expected winter stresses will be required. We need to understand the fundamental regulatory mechanisms behind yield formation of forage grasses under changing temperature and photoperiod conditions. Understanding the genetic regulation of adaptive traits such as flowering time, cold acclimation and winter survival is crucial to developing new, improved and persistent high-yielding cultivars with high feeding value.

Germplasm - Development of efficient methods for utilisation of wild-adapted genetic resources and un-adapted exotic germplasm is 
necessary for developing new cultivars rapidly enough to keep pace with the changing growing conditions resulting from climate change.

\section{Publications}

Asp, T., Byrne, S., Gundlach, H., Bruggmann, R., Mayer, K. F. X., Andersen, J. R., Xu, M. L., Greve, M., Lenk, I. and Lubberstedt, T., 2011. Comparative sequence analysis of VRN1 alleles of Lolium perenne with the co-linear regions in barley, wheat, and rice. Molecular Genetics and Genomics, 286,433-447.

Bleken, M.A., Ergon, Å. and Rognli, O.A., 2013. Species mixtures - nitrous oxide emissions after application of synthetic urine. Grassland Science in Europe, 18, 162-164, 17th EGF Symposium. Akureyri, Iceland, 23-26 June 2013. ISBN 978-9979-881-20-9.

Byrne, S., Czaban, A., Studer, B., Panitz, F., Bendixen, C. and Asp, T., 2013. Genome wide allele frequency fingerprints (GWAFFs) of populations via genotyping by sequencing. Plos One, 8 (3).

Dalmannsdottir, S., Jørgensen, M., Østrem, L., Rapacz, M., Larsen, A. and Rognli, O.A., 2014. Vil varmere høster gi dårligere overvintring? Bioforsk FOKUS, 9(2), 68.

Dalmannsdottir, S., Rapacz, M., Jørgensen, M., Østrem, L., Larsen, A. and Rognli, O.A., 2013. Effects of pre-acclimation temperature on cold tolerance and photoinhibition in forage species. Grassland Science in Europe, 18, 288-290, 17th EGF Symposium. Akureyri, Iceland, 23-26 June 2013. ISBN 978-9979-881-20-9.

Dalmannsdottir, S., Østrem, L. and Larsen, A., 2011. Effect of water saturation of soil on winter survival of red clover (Trifolium pratense) and timothy (Phleum pratense) in Norway. Grassland Science in Europe, EGF, Vol. 17, 103-105. Poznan, Poland. ISBN 978-83-89250-77-3.

Ergon, Å., Bleken, M.A., Lunnan, T., Skjelvåg, A.O. and Rognli, O.A., 2013. Species mixtures - dry matter yield and herbage quality as affected by harvesting frequency under low $N$ supply. Grassland Science in Europe, 18, 204-206, 17th EGF Symposium. Akureyri, Iceland, 23-26 June 2013. ISBN 978-9979-881-20-9.

Ergon, A., Hamland, H. and Rognli, O.A., 2013. Differential expression of VRN1 and other MADS-box genes in Festuca pratensis selections with different vernalization requirements. Biologia Plantarum, 57,245-254.

Gaudet, D.A., Tronsmo, A.M. and Laroche, A., 2012. Climate Change and Plant Diseases. In: K.B. Storey and K.K. Tanino, eds. Temperature Adaptation in a Changing Climate: Nature at Risk. CAB International. Chapter 10, pp. 144-158. ISBN-13 9781845938222.

Höglind, M. and Thorsen, S.M., 2011. Effekter av klimaendringer på framtidig fôrproduksjon i Norden. Bioforsk FOKUS, 6(2), 105.

Höglind, M., Thorsen, S.M. and Semenov, M.A., 2013. Assessing uncertainties in impact of climate change on grass production in Northern Europe using ensembles of global climate models. Agricultural and Forest Meteorology, 170, 103-113.

Islam, M.S., Studer, B., Byrne, S.L., Farrell, J.D., Panitz, F., Bendixen, C., Møller, I.M. and Asp, T., 2013. The genome and transcriptome of perennial ryegrass mitochondria. BMC Genomics, 14.

Jokela, V. and Seppänen, M., 2013. Molecular regulation of flowering in timothy (Phleum pratense L.). Grassland Science in Europe, 18, 291-293, 17th EGF Symposium. Akureyri, Iceland, 23-26 June 2013. ISBN 978-9979-881-20-9.

Jokela, V., Virkajärvi, P., Tanskanen, J. and Seppänen, M., 2013. Vernalization, gibberellic acid and photo period as regulators of yield formation in timothy. Physiologia Plantarum. Published online 23 January 2014. DOI: 10.1111/ppl.12141. 
Larsen, A., Østrem, L. and Rognli, O.A., 2011. Festulolium for northern growing conditions. In: A. Kosmala, M. Humphreys, M. Ghesquière and Z. Zwierzykowski, eds. The 1st EUCARPIA Festulolium Working Group Workshop. Final Report, 35-36. ISBN 978-83-85583-25-7.

Persson, T. and Höglind, M., 2014. Impact of climate change on harvest security and biomass yield of two timothy ley harvesting systems in Norway. Journal of Agricultural Science, 152, 205-216.

Rapacz, M., Ergon, Å., Höglind, M., Jørgensen, M., Jurczyk, B., Østrem, L., Rognli, O.A. and Tronsmo, A. M., 2014. Overwintering of herbaceous plants in a changing climate - still more questions than answers. Plant Science, 225, 34-44.

Rognli, O.A., Fjellheim, S., Pecetti, L. and Boller, B., 2013. Semi-natural grasslands as a source of genetic diversity. Grassland Science in Europe, 18, 303-313, 17th EGF Symposium. Akureyri, Iceland, 23-26 June 2013. ISBN 978-9979-881-20-9.

Rognli, O.A., 2013. Breeding for Improved Winter Survival in Forage Grasses. In: R. Imai, M. Yoshida and N. Matsumoto, eds. Plant and Microbe Adaptations to Cold in a Changing World. New York, USA: Springer. pp. 197-208.

Seppänen, M., Jokela, V., Korhonen, P., Isolahti, M. and Virkajärvi, P., 2013. The role of vernalization in freezing tolerance and tiller composition of forage grasses. Grassland Science in Europe, 18, 297-299, 17th EGF Symposium. Akureyri, Iceland, 23-26 June 2013. ISBN 978-9979-881-20-9.

Studer, B., Byrne, S., Nielsen, R.O., Panitz, F., Bendixen, C., Islam, M.S., Pfeifer, M., Lubberstedt, T. and Asp, T., 2012. A transcriptome map of perennial ryegrass (Lolium perenne L.). BMC Genomics, 13.

Tronsmo, A.M., 2013. Snow moulds in a changing environment - a Scandinavian perspective. In: R. Imai, M. Yoshida and N. Matsumoto, eds. Plant and Microbe Adaptations to Cold in a Changing World. New York, USA: Springer. Chapter 26, pp. 305317. ISBN: 978-1-4614-8252-9 (Print) 978-1-4614-8253-6 (Online)

Vigeland, M.D., Spannagl, M., Asp, T., Paina, C., Rudi, H., Rognli, O. A., Fjellheim, S. and Sandve, S.R., 2013. Evidence for adaptive evolution of low-temperature stress response genes in a Pooideae grass ancestor. New Phytologist, 199, 1060-1068.

Østrem, L., 2013. Fleirårig raigras i nye dyrkingsområde. Buskap, 3, 76-77.

Østrem, L., Höglind, M., Jørgensen, M. and Dalmannsdottir, S., 2013. Recent studies at Bioforsk on winter stress in forage species. Bioforsk FOKUS, 8(5), 13-14.

Østrem, L., Höglind, M., Karlsen, Å., Marum, P., Tronsmo, A.M. and Rognli, O.A., 2010. Adaptation of Norwegian perennial forage crops to future climate. In: J. Rasmussen, M. Schacht and Á. Helgadóttir, eds. The potential of forage legumes to sustain a high agricultural productivity - a Nordic perspective. Proceedings from NJF Seminar 432. NJF Report, Vol. 6, No. 3, 21-24. Hvanneyri, Iceland, 20-22 June 2010.

Østrem, L. and Marum, P., 2013. Hardføre raigrassortar - kor hardføre? Bioforsk FOKUS, 8(2), 166-168.

Østrem, L., Marum, P. and Larsen, A., 2014. Framtidige plantegen - kor finst dei? Bioforsk FOKUS, 9(2), 66.

Østrem, L., Rapacz, M., Larsen A., Dalmannsdottir, S. and Jørgensen, M., 2013. How do non-adaptive grasses control growth cessation during autumn in high-latitude regions? Grassland Science in Europe, 18, 361-363, 17th EGF Symposium. Akureyri, Iceland, 23-26 June, 2013.ISBN 978-9979-881-20-9.

\section{Manuscripts}

Abdelhalim, M., Hofgaard, I.S., Rognli, O.A., Østrem, L. and Tronsmo, A.M. Resistance to snow moulds in different populations of perennial ryegrass and Festulolium. 
Dalmannsdottir, S., Rapacz, M., Jørgensen, M., Østrem, L., Larsen, A. and Rognli, O.A. Effects of pre-acclimation temperature on cold tolerance and photoinhibition in timothy (Phleum pratense), perennial ryegrass (Lolium perenne) and red clover (Trifolium pratense).

Jokela, V., Toivonen, T. and Seppänen, M. The regulation of canopy structure in timothy (Phleum pratense L.) genotypes of different origin.

Kovi et al. Detecting genome-wide shifts in allelic composition by sampling in swards of a broad-based mixture of perennial ryegrass (Lolium perenne L.) and timothy (Phleum pratense) grown and managed at five locations in Norway.

Kovi, M.R., Höglind, M., Ergon, A., Hanslin, H.M., Byrne, S., Asp, T. and Rognli, O.A. An $R N A$ seq approach revealed the global transcriptome changes affected by vernalization and cold hardening in Lolium perenne.

Kovi, M.R., Höglind, M., Ergon, Å., Hanslin, H.M., Byrne, S., Asp, T. and Rognli, O.A. Global transcript profiling under hardening/dehardening conditions in Festulolium.

Rognli, O.A., Kovi, M.R., Byrne, S., Asp, T., Studer, B., Kent, M.P. and Sandve, S.R. Population structure, genetic variation and linkage disequilibrium in perennial rye grass populations divergently selected for frost tolerance.

Østrem, L., Rapacz, M., Larsen, A., Dalmannsdottir, S. and Jørgensen, M. Growth cessation in autumn, photosynthetic activity and winter hardiness in non-adaptive LoliumFestuca species at high-latitude regions. A challenge in the face of climate change.

\section{PhD thesis}

Paina, C., 2014. Elucidating the vernalization response in Lolium perenne. $\mathrm{PhD}$ thesis, Department of Molecular Biology and Genetics, Aarhus University, Aarhus, Denmark, pp 168.

\section{Master theses}

Kunapareddy, A., 2013. Transcriptome analysis of perennial ryegrass (Lolium perenne L.) during an early stage infection to pink snow mould. Master thesis, Norwegian University of Life Sciences, Ås, Norway, pp 69.

Korhonen, P., 2014. Development of freezing tolerance and vernalization in forage grasses - field experiments 2009-2013. Master thesis, Helsinki University, Helsinki, Finland.

Luhtanen, J., 2011. The impact of forage grass origin on freezing tolerance, vernalization response and growth. Master thesis, Helsinki University, Helsinki, Finland.

Toivonen, T., 2014. Genotypic variation of forage grasses in fall growth. Master thesis, Helsinki University, Helsinki, Finland.

\section{Posters}

Abdelhalim, M., Brurberg, M.-B., Hofgaard, I.S., Kovi, M.R., Ergon, Å., Rognli, O.A. and Tronsmo, A.M., 2014. Towards a better understanding of snow mould resistance in perennial ryegrass. In: Præbel A, Groeneveld LF (editors), 2014, Book of Abstracts, Genetic Resources for Food and Agriculture in a Changing Climate, 27-29 January, 2014, Lillehammer, Norway. The Nordic Genetic Resource Center, Ås, Norway, p. 55.

Abdelhalim, M., Ergon, Å., Kovi, M.R., Kunapareddy, A., Brurberg, M.B., Hofgaard, I., Tronsmo, A.M. and Rognli, O.A., 2012. Gene expression analysis of perennial ryegrass (Lolium perenne L.) during pink snow mould infection. NOVA PhD course: Innate Immunity of Plants, University of Helsinki, Mikkeli, Finland. 
Dalmannsdottir S., Jørgensen M., Rapacz M., Østrem L., Larsen A. and Rognli O.A., 2014. Effect of temperature under decreasing photoperiod on cold tolerance of timothy and perennial ryegrass in N-Norway. In: Præbel A. and Groeneveld, L.F. (Eds.), Book of abstracts, Genetic Resources for Food and Agriculture in a Changing Climate, 27-29 January, 2014, Lillehammer, Norway. The Nordic Genetic Resource Center, Ås, Norway, p. 57.

Ergon, Å. and Rognli, O.A., 2014. Genomic characterization of survivor populations of red clover exposed to contrasting treatments in a field experiment. In: Præbel A, Groeneveld LF (editors), 2014, Book of Abstracts, Genetic Resources for Food and Agriculture in a Changing Climate, 27-29 January, 2014, Lillehammer, Norway. The Nordic Genetic Resource Center, Ås, Norway, p. 59.

Helgadóttir, Á. and Kristjánsdóttir, T.A., 2014. NDVI measurements in autumn can predict winter survival of non-adapted grasses at high latitudes. In: Præbel A, Groeneveld LF (editors), 2014, Book of Abstracts, Genetic Resources for Food and Agriculture in a Changing Climate, 27-29 January, 2014, Lillehammer, Norway. The Nordic Genetic Resource Center, Ås, Norway, p. 61.

Höglind, M., van Oijen, M. and Persson, T., 2014. Breeding forage grasses: simulation modelling as a tool to identify important cultivar characteristics for winter survival and yield under future climate conditions in Norway. In: Præbel A, Groeneveld LF (editors), 2014, Book of Abstracts, Genetic Resources for Food and Agriculture in a Changing Climate, 27-29 January, 2014, Lillehammer, Norway. The Nordic Genetic Resource Center, Ås, Norway, p. 62.

Kinmonth-Schultz, H., Lewandowska-Sabat, A., Fjellheim, S. and Rognli, O.A., 2014. Gene expression among natural Arabidopsis populations in a common garden correlates with flowering and to the population's home climates. In: Præbel A, Groeneveld LF (editors), 2014, Book of Abstracts, Genetic Resources for Food and Agriculture in a Changing Climate, 27-29 January, 2014, Lillehammer, Norway. The Nordic Genetic Resource Center, Ås, Norway, p. 64.

Kovi, M.R., Amdahl, H., Wilson, R.C., Marum, P., Asp, T., Alsheikh, M. and Rognli, O.A., 2014. Global transcript profiling for seed setting in autotetraploid red clover by RNA sequencing. In: Præbel A, Groeneveld LF (editors), 2014, Book of Abstracts, Genetic Resources for Food and Agriculture in a Changing Climate, 27-29 January, 2014, Lillehammer, Norway. The Nordic Genetic Resource Center, Ås, Norway, p. 64.

Kovi, M.R., Ergon, Å., Kunapareddy, A., Abdelhalim, M., Asp, T., Tronsmo, A.M. and Rognli, O.A., 2014. Global transcriptome changes in perennial ryegrass during early infection by pink snow mould. In: Præbel A, Groeneveld LF (editors), 2014, Book of Abstracts, Genetic Resources for Food and Agriculture in a Changing Climate, 2729 January, 2014, Lillehammer, Norway. The Nordic Genetic Resource Center, Ås, Norway, p. 65.

Kovi, M.R., Höglind, M., Hanslin, H.M., Ergon Å., Asp, T. and Rognli, O.A., 2013. Comparison of hardening/de-hardening conditions in Lolium perenne and Festulolium. International Plant \& Animal Genome XXI (12-16 January 2013), San Diego, USA.

Kovi, M.R., Sandve, S.R, Ergon Å., Studer, B., Asp, T., Kent, M.P. and Rognli, O.A., 2012. Genetic variation, population structure and linkage disequilibrium in perennial ryegrass populations divergently selected for frost tolerance. 7th International Symposium on Molecular Breeding of Forage and Turf (MBFT, 4-7 June 2012), Salt Lake City, Utah, USA.

Jokela, V., Luhtanen, J., Virkajärvi, P. and Seppänen, M., 2012. Effects of vernalization on freezing tolerance and canopy structure of timothy. The $12^{\text {th }}$ Congress of the European Society of Agronomy. Helsinki, Finland. 20-24.8.2012. 
Jokela, V. and Seppänen, M., 2012. Expression of VRN1 and VRN3 homologs in timothy (Phleum pratense L.). The $10^{\text {th }}$ International Congress on Plant Molecular Biology. Jeju, South Korea 21-26.10.2012.

Jokela, V. and Seppänen, M., 2012. The environmental control of canopy development in timothy (Phleum pratense L.). The Society of Experimental Biology Annual Meeting. Salzburg, Austria. 29.6.-2.7.2012.

Palmé, A., Marum, P., Öhlund, L., Leino, M., Hagenblad, J., Solberg, S.Ø. and Asdal, Å., 2014. Genetic consequences of ex situ and in situ conservation of plant genetic resources: An on-going study in red clover (Trifolium pratense). In: Præbel A, Groeneveld LF (editors), 2014, Book of Abstracts, Genetic Resources for Food and Agriculture in a Changing Climate, 27-29 January, 2014, Lillehammer, Norway. The Nordic Genetic Resource Center, Ås, Norway, p. 67.

Schubert, M., Sandve, S.R. and Fjellheim, S., 2014. Evolution of vernalization and daylength response in the grass subfamily Pooideae as an adaptation to seasonal and cool climates. In: Præbel A, Groeneveld LF (editors), 2014, Book of Abstracts, Genetic Resources for Food and Agriculture in a Changing Climate, 27-29 January, 2014, Lillehammer, Norway. The Nordic Genetic Resource Center, Ås, Norway, p. 71.

Solberg, S.Ø., Bragason, A., Helgadottir, A., Dalmannsdottir, S., Djurhus, R. and Frederiksen, A., 2014. Access to plant genetic resources for food production in the Arctic. In: Præbel A, Groeneveld LF (editors), 2014, Book of Abstracts, Genetic Resources for Food and Agriculture in a Changing Climate, 27-29 January, 2014, Lillehammer, Norway. The Nordic Genetic Resource Center, Ås, Norway, p. 72.

Østrem, L., Baert, J., Barth, S., Cernoch, V., Ghesquière, M., Grogan, D., Humphreys, M.W., Sokolović, D., Paszkowski, E. and Zwierzykowski, Z., 2014. Using genome interactions in Festulolium to mitigate climatic change on forage production across Europe. In: Præbel A, Groeneveld LF (editors), 2014, Book of Abstracts, Genetic Resources for Food and Agriculture in a Changing Climate, 27-29 January, 2014, Lillehammer, Norway. The Nordic Genetic Resource Center, Ås, Norway, p. 76.

\subsubsection{Network 6: Arctic char: a species under threat and with great potentials in the age of climate change - NORDCHAR}

Arctic char is an Arctic fish species with a circumpolar distribution. At present, the Arctic char is retreating from its southernmost locations. The distribution and biology of the Arctic char makes it an ideal model species for studying the effects of climate change on cold-adapted fish species and fish in general. The NORDCHAR project is multi-disciplinary, combining ecology, biogeography, evolution and genetics. This project seeks to enhance our understanding on aspects of biodiversity, evolutionary mechanisms of speciation and adaptive ecology for Arctic aquatic ecosystems. The resulting information will be of great importance in interpreting potential impacts of anthropogenically-induced climate change on northern aquatic ecosystems. The results will also be important in managing the resources in respect to conservation and utilisation in fisheries and aquaculture alike. 
In this project, the Nordic countries join forces to accumulate biological data on Arctic char and add new knowledge on its genetic diversity. As Arctic char has a circumpolar distribution, valuable knowledge can be gathered from other areas. Prestigious scientists from Canada and Scotland are participating in NORDCHAR.

Many detailed ecological studies on Arctic char have been conducted. By comparing the vast amount of available data on Arctic char ecology, life history profiles, population patterns and their environment both in the Nordic countries as well as in other areas, better understanding on the interplay between climate change and Arctic char biology can be achieved. The life history of Arctic char populations can be complex, e.g. populations can be resident or anadromous or both to some degree. Anadromy, which is generally restricted to northern areas, has been suggested to develop when conditions for feeding, growth and overall survival and life-time fecundity in fresh water are less favourable compared to seawater. The size and age at first maturation as well as length of life span is also highly variable depending on locations.

A new synchronised genetic tool has been developed to study selected populations. A map of the overall genetic diversity of Arctic char has now been produced. We collected 5-6 individuals from more than 30 populations from the entire distribution area (Figure 11.1). It was decided to sequence the whole mitochondrial DNA (mtDNA) to map the genetic variation (step 1). We chose to study the mtDNA as it interacts with the nuclear genome to produce enzyme systems involved in the energy production of the cells. The genetic characteristics of the mtDNA can therefore be expected to be sensitive to temperature conditions, as the char is a poikilotherm (body temperature varies with environmental temperatures). In step 1, we identified 468 SNP (single nucleotide polymorphism) variations (Figure 11.2). In step 2, selected regions of the mtDNA were sequenced for 1600 individuals. For step 2, we chose to sequence six regions (amplicons) of the mtDNA genome that were highly variable; ND1, ND2, ND5, ND6 and two regions on the D-loop (Figure 11.3). Of the 1,600 individuals, 60 were specifically for phylogenetics of different-named char from the Salvelinus complex. The remaining 1,540 samples were from approximately 80 different populations of Arctic char from the entire distribution area of the species.

In this study, the evolution and divergence of the Arctic char is being mapped. The results can be used to understand and further investigate both historical and contemporary aspects of the phylogeographic structure of the species. 


$$
\bar{v}
$$


Figure 11.3: An overview of the Artic char's mtDNA and the areas sequenced in step 2 of the genetic work

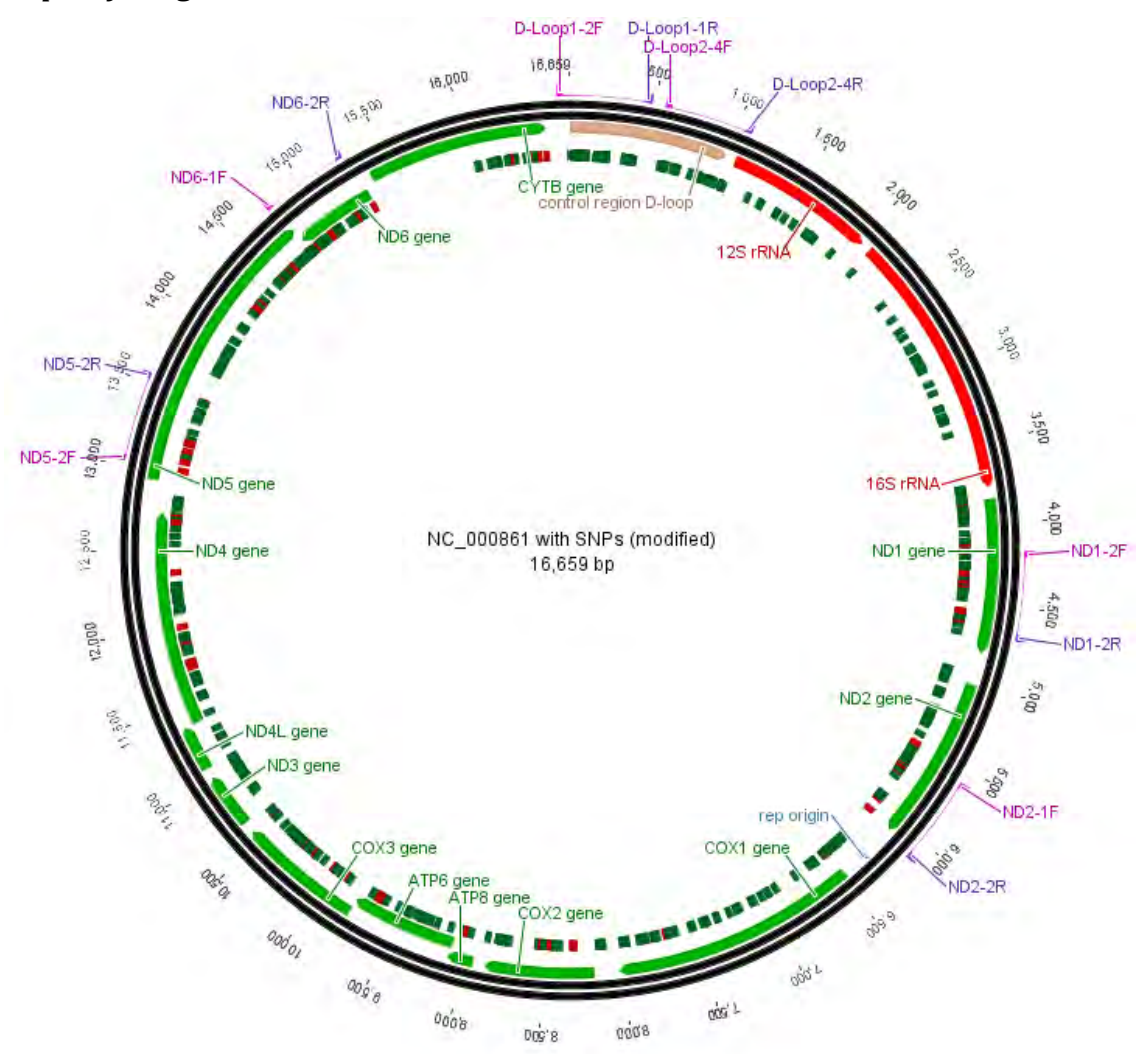

Figure 11.4: Principle coordinates analysis (PCoA) of genetic distance among Arctic char samples (step 2). Two genetic groups can be seen

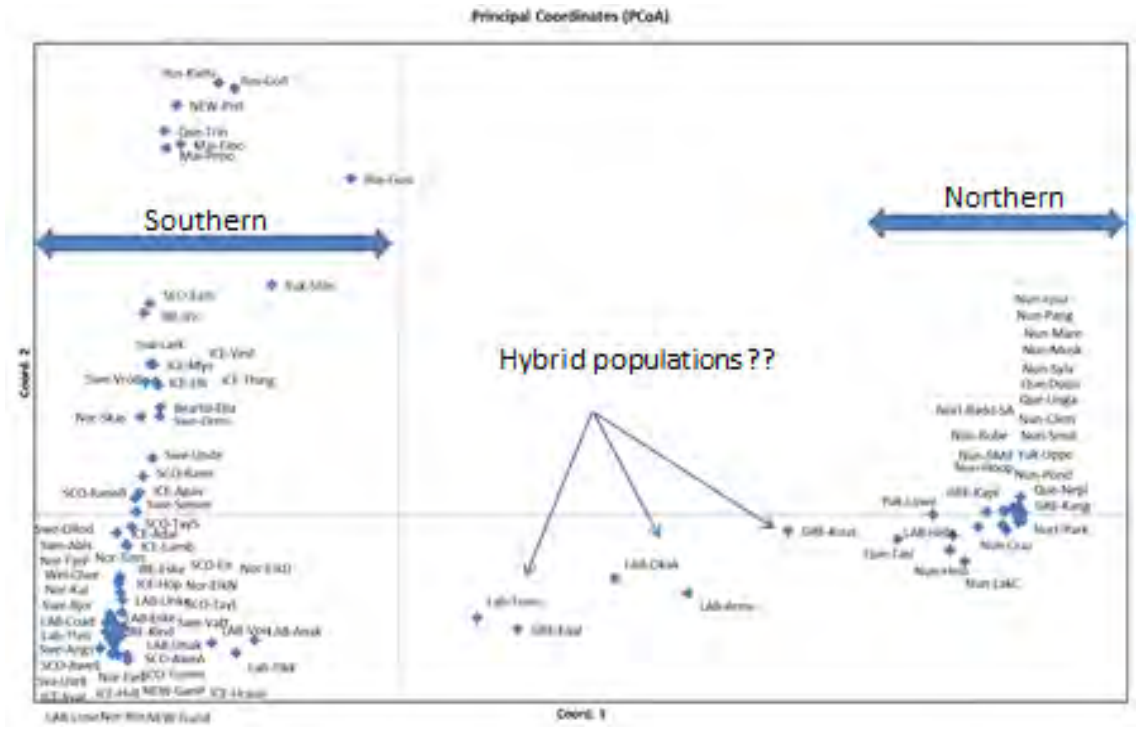

Source: Tamura and Nei (1993). 
Our results show that Arctic char can be divided into two main groups or phylogeographic lineages: one in the northernmost part of North America and another in the remaining part of the distribution area. In Labrador, hybrids of the two groups can be found (Figure 11.4). The two groups can further be divided into subgroups. For example, char in the southern part of its distribution in North America form a group (Maine and New Brunswick). Further analysis of char in different locations can and will be done. Some publications in scientific journals have been planned. Detailed description of mtDNA SNP variation will be done based on the samples from the first phase of the study. We plan to write and publish papers on the construction of a more or less definitive mitochondrial, maternal phylogenetic tree for the Arctic char as well as detailed analysis of the divergence of sympatric morphs. Placing Arctic char divergence in the broader context of divergence within the genus Salvelinus and the family Salmonidae is also an important task. The involvement of any SNPs in temperature-related selective genetic responses must also be assessed. Analyses of life history data and morphological characteristics also show variation and in some instances can be related to geographical location. Studying the relationships between genetic and life history characteristics is another task we have initiated. Some trends can already be seen in the Arctic char, a highly variable and plastic species.

Climate change is expected to have a profound impact on natural resources, and thus on the primary industries (agriculture, forestry and fisheries) in the Nordic countries. Climate change induces risks but also creates possibilities for new production systems on land and in the ocean. Climatic changes also represent great challenges for policymaking and management regimes. The current knowledge base on natural resources in the Nordic region needs to be expanded to fully address the impacts of climate change. In particular it is important to address the need for improved policies and new policy instruments. The research programme Climate Change Impacts, Adaptation and Mitigation in Nordic Primary Industries is a coordinated set of thematic research networks with the objective to create a Nordic knowledge base on climate change interactions with primary industries in the Nordic region.

Keywords: Agriculture, forestry, fisheries, climate change, adaptation, mitigation. 


\section{Sammendrag}

Som følge av økonomisk vekst og en raskt voksende middelklasse ventes den globale etterspørselen etter høykvalitetsmat, som kjøtt og fisk, nesten å dobles fram mot 2050. Med mindre nye teknologier og mer effektiv ressursbruk utvikles vil dette føre til tilsvarende økning i utslipp av klimagasser $\left(\mathrm{CO}_{2}\right.$, metan og nitrogenoksid) fra kjøtt- og planteproduksjon, i tillegg til utslipp fra fossile brensler i primærnæringene.

Jordbrukssektoren dominerer utslippene av klimagasser fra primærnæringene i de nordiske landene. Utslipp fra disse sektorene varierer mellom rundt $5 \%$ av totale nasjonale utslipp på Island, til over $20 \%$ i Danmark. Globalt bidrar fiskebåter til 1-2 \% av utslippene av $\mathrm{CO}_{2}$. Samtidig tilsvarer opptaket av karbon i nordiske skoger $43 \%$ av samlede utslipp som følge av økt biomasse.

Den forventede temperaturøkningen mot slutten av 21. århundre vil i stor grad avhenge av framtidige utslipp. Forlengelse av dagens utslippstrender gir en forventet gjennomsnittlig temperaturøkning på mellom $2.6^{\circ} \mathrm{C}$ og $4.8^{\circ} \mathrm{C}$, og med lavere utslipp mellom $1.4^{\circ} \mathrm{C}$ og $3.1^{\circ} \mathrm{C}$. I Norden vil temperaturøkningen tilsvare det globale gjennomsnittet i sør og vest og det det dobbelte i nord og øst. Økningen vil bli størst om vinteren og i områder med kontinentalt klima. Det er ventet mer nedbør og mer ekstreme værforhold, mens endringene i vindforhold er usikre. Varmt vann transportert med Golfstrømmen er ventet å reduseres med $20 \%$ til $30 \%$ mot slutten av århundret. Oppvarmingen vil også redusere snø- og isdekket. Det er estimert at snødekket vil reduseres med 1-3 måneder i regionen.

Den nordiske regionen er den eneste delen av jorden der klimaforholdene tillater produktivt jordbruk, skogbruk og fiske på så høye breddegrader og mørke vintre. Temperaturøkningen er forventet å bli større enn det globale gjennomsnittet på de nordligste breddegradene. Dette vil føre til nye klimatiske forhold vinterstid, som man hittil ikke har erfaring med. Effektene av slike endringer er vanskelige - for ikke å si umulige - å forutse, og forskningen gir mangelfullt grunnlag for vurderinger av potensielle effekter for økosystemer og hvordan klimaendringer vil påvirke produktivitet og drift i jordbruk, skogbruk og fiske.

Jordsmonnet i den nordiske regionen har generelt vesentlig høyere karboninnhold enn i andre deler av Europa. Temperaturøkningen øker 
dekomponeringen av organiske materialer i jord som videre kan øke nitrogentilførselen til økosystemer innenfor både skog- og jordbruk. Dette sammen med forlenget vekstsesong øker skogveksten, tømmerproduksjonen og karbonlagringen i den nordiske regionen. Karbonlagringen $\mathrm{i}$ biomassen er forventet å øke jevnt som følge av høyere $\mathrm{CO}_{2}$ konsentrasjon i atmosfæren. Endringer i karboninnholdet i jordsmonn er mer usikkert.

Den mest fremtredende følgen av global oppvarming i Norden vil trolig bli flytting av økosystemer og arter og tilhørende endringer produktiviteten for jordbruk, skogbruk og fiske.

Oppvarmingen vil påvirke produksjonen av phytoplankton i havet. Sammen med endringer i havtemperatur og saltinnhold vil dette endre fordelingen og produksjonen for sentrale marine fiskearter. Forskjellige arter vil flytte nordover i ulik takt, noe som endrer sammensetningen av predatorer, byttedyr og konkurrenter. Dette vil føre til nye typer interaksjon mellom arter, som igjen vil påvirke produktiviteten. Endringer i lokalisering og migrasjon av fiskebestander kan også utfordre eksisterende avtaler om deling av fiskebestander eller føre til behov for helt nye avtaler. Ferskvannsfisk vil også møte endringer i den geografiske fordeling, som vil påvirke kommersielt fiske og fritidsfiske.

Jordbruksproduksjonen vil flyttes nordover, med økt produktivitet og bredere utvalg av jordbruksprodukter i de fleste regioner, i områder med egnet terreng og jordsmonn. Innenfor skogbruk vil tresorter flytte lenger nordover og til mer høytliggende områder. Forlenget vekstsesong vil også øke skogsmassen og produktiviteten i nordiske skoger.

Mens klimaendringer gir bedre forhold for jordbruk, skogbruk og fiske i de nordiske landene, vil det også tilføre nye risikofaktorer i sammenheng med biotisk og abiotisk stress for planter og dyr. Mer varierende sesonger og økt frekvens av ekstremvær, slik som varmebølger, tørke, storm og intenst regn, fører med seg nye og endrede trusler for produksjonssystemene. Innenfor jordbruk vil avlinger påvirkes, og husdyrproduksjonen kan bli redusert på grunn av fórmangel og varmestress. Innenfor skogbruk er det ventet at brann og storm vil øke risikoen for skogskader. Risiko for utbrudd av skadedyr og sykdommer, som skaper veksttap, tømmerskader og massiv skogdød, ventes også å øke. I ferskvann kan ekstremvær som flom og tørke redusere rekruttering og overlevelse for fisk.

Oppvarmingen vil ikke bare påvirke plante- og dyrearter innenfor primærnæringene, men også betingelsene for skadedyr og sykdommer som påvirker avlingene. Det vil kunne bli nødvendig å håndtere nye typer ugress, skadedyr og sykdommer som er tilpasset varmere forhold. 
Generelt trengs nye tilnærminger for å unngå økt bruk av plantevernmidler. Husdyrproduksjonen vil møte nye og endrede sykdommer overført via insekter eller matvarer som er tilpasset nye klimatiske forhold. Noen av disse sykdommene vil også kunne overføres mellom mennesker og dyr, som nødvendiggjør nøye oppfølging av utviklingen.

Siden det kan være langt frem før nye teknologier, materialer eller styringssystemer kan implementeres, og siden det vil være nødvendig å involvere flere aktører eller institusjoner, er det spesielt viktig å legge vekt på tilpasninger. Det bør legges vekst på arealplanlegging og drift, bruk av genetiske ressurser for både planter og dyr, og håndtering og hindring av dyre- og plantesykdommer. Disse områdene trenger spesiell oppmerksomhet for å sikre at offentlig planlegging og insentiver legger til rette for effektive tilpasninger hos private aktører. Ved utvikling av nye teknologier og styringssystemer for klimatilpasninger bør en også ta hensyn til behovet for å redusere utslippene av klimagasser og øke opptak og lagring av karbon i skog og jord. 


\section{norden}

Nordic Council of Ministers

Ved Stranden 18

DK-1061 Copenhagen K

www.norden.org

\section{Climate change and primary industries}

Climate change is expected to have a profound impact on natural resources, and thus on the primary industries (agriculture, forestry and fisheries) in the Nordic countries. Climate change induces risks but also creates possibilities for new production systems on land and in the ocean. Climatic changes also represent great challenges for policy-making and management regimes. The current knowledge base on natural resources in the Nordic region needs to be expanded to fully address the impacts of climate change. In particular it is important to address the need for improved policies and new policy instruments. The research programme Climate Change Impacts, Adaptation and Mitigation in Nordic Primary Industries is a coordinated set of thematic research networks with the objective to create a Nordic knowledge base on climate change interactions with primary industries in the Nordic region.

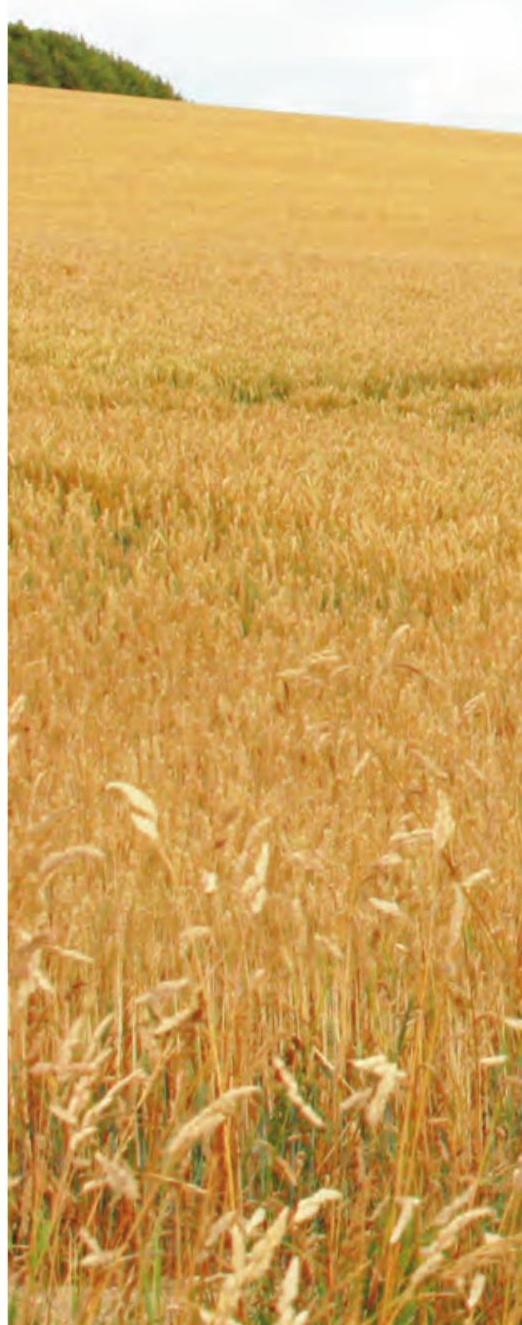

